\title{
ENVIRONMENTAL AND NUTRITIONAL IMPACTS OF CHANGING DIETS AND FOOD WASTE IN SPAIN
}

\author{
TESIS DOCTORAL \\ Alejandro Blas Morente INGEniero Agrónomo
}

Directores

Alberto Garrido Colmenero Dr. Ingeniero Agrónomo

Universidad Politécnica de Madrid

Bárbara Anna Willaarts Dra. Planificación Ambiental

International Institute for Applied Systems Analysis (IIASA), Laxenburg, Austria 


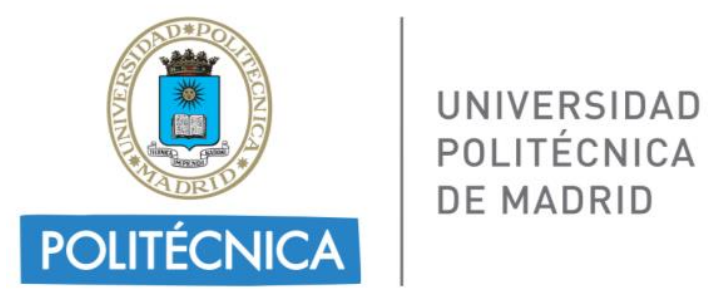

Tribunal nombrado por el Sr. Rector Magfco. de la Universidad Politécnica de Madrid, el día de de $201 \ldots$

Presidente:

Vocal:

Vocal:

Vocal:

Secretario:

Suplente:

Suplente:

Realizado el acto de defensa y lectura de la Tesis el día ...... de en la E.T.S.I./Facultad

Calificación

EL PRESIDENTE

LOS VOCALES

EL SECRETARIO 

A mis padres; José Luis y Oliva, e Iván 



\section{AGRADECIMIENTOS}

Durante todos estos años de realización de la Tesis Doctoral, tengo que agradecer a muchas personas e instituciones, el gran apoyo, ayuda y confianza que me han mostrado para su escritura y finalización.

De una manera muy especial, y, en primer lugar, a mis dos tutores; Alberto Garrido y Bárbara Willaarts. A Alberto le tengo que agradecer su gran dedicación, apoyo y esfuerzo con la que se ha entregado desde el principio, ha sido un gran tutor, que me ha sabido llevar (no solo estos tres años de Tesis, sino unos cuantos más como investigador) con gran templanza, educación y saber, mi camino para convertirme en doctor y buen profesional; gracias por confiar en mí todos estos años. Y qué decir de Bárbara, que desde que apareció para ayudarme cuando estaba atascado en mi primer artículo, se quedó para ser una gran tutora. Gracias a ella sin duda he realizado esta Tesis, y sin ella aún estaría pensando que hacer. Ha sido enorme su apoyo, ánimos y esfuerzo (que ha hecho en cualquier lugar desde donde se encontraba) para que saliese adelante esta Tesis... imenos mal que entré ese día en tu despacho! Gracias.

Agradecer igualmente a las instituciones gracias a las cuales he podido realizar esta Tesis. En primer lugar, al Observatorio del Agua de la Fundación Botín, el cual me ha financiado y apoyado el proyecto de investigación. Desde que entré a formar parte del equipo, hasta hoy en día, me ha apoyado para la consecución de la Tesis. En especial agradecer al equipo actual (Toni, Gabi, Lucia y Alberto) el apoyo, compañerismo y profesionalidad mostrado. También a Maite Aldaya, que me ayudó en mis primeras incursiones de la Huella Hídrica y a Michelaina Jhonson por el trabajo con la Dieta Americana. A Paulo Dias y Olcay Unver de FAO-Roma, y Jan Lundqvist de SIWI, por la ayuda y la participación en el tercer artículo durante mi estancia. A Javier Mazorra, por ayudarme tanto este último año de Tesis en todo, iY a la Co-Co, sin ella estos últimos meses de finalización de Tesis hubiesen sido mucho más difíciles e interminables...gracias Sori!

Agradecer enormemente a CEIGRAM. No solo ha sido mi lugar de trabajo durante casi 6 años, sino que también ha sido el sitio donde me he desarrollado personalmente, y he conocido a gente maravillosa y verdaderos amigos. Gracias a los antiguos Ceigrameros (Lola, Dani, Elenita, Jorge, Gloria, Paula, Berta, Sori, Willaarts, Ana Felis...) por los momentos tan divertidos y maravillosos que he pasado con ellos desde que entré. Berta, gracias por todos esos momentos al solecito, conversaciones, consejos y risas. A Ana Felis por ayudarme en Madrid y en Roma a todo. También a Bego por ayudarme en todo momento, a los directores que han pasado (Alberto, Inés Minguez, Jose María Sumpsi), a los profesores e investigadores senior, con los cuales con algunos he trabajado (Isabel Bardají, Ana Tarquis, Carlos Gregorio, Rubén, Ana Iglesias, Irene...), a los del Reino del Norte (Castaño; a ver cuándo repetimos un Elche!, Rhys, Pilar, Benito), ya los actuales y/o intermedios Ceigrameros (Marina, Omar, Ivanka, Jhenny, Iñigo, Hamid, Ángel, Luis, 
Alberto, María Alonso, Daniele, David, Mariza, Andrés, Afsane...). iY por último...a las matriarcas del Ceigram! Madre mía, iKat y Espe... gracias a vosotras funciona esto!, gracias a Kat por toda la ayuda, dedicación y buenos momentos estos 6 años...y gracias Luque...iipor todo!! Gracias a ti muchos seguimos aquí, eres la unión de todo y has sido fundamental para que yo haya terminado esta Tesis... igracias a las dos por ser el epicentro del Ceigram gracias al cual todo gira!

No me podría olvidar de los casi 6 meses maravillosos y felices que he pasado en Roma en la sede central de la FAO. Gracias a mis jefes; Eduardo Mansur, Olcay Unver y Paulo Dias por haber hecho posible la estancia, y tutorarme en todo momento. Han sido meses en los que he aprendido (mucho), disfrutado y...conocido. Conocido a gente maravillosa y verdaderos amigos, como Rahmi (un placer haberte llevado tu TFM pequeña Indonesa), Natalia, Yusuf, Yuxin, y el resto del equipo del despacho de CBL. A Vera, Dario, Baris y Stephani, por todos los planes y comidas, risas y momentos que pasamos. A Dieguito y Kristof... por el futbol, el Yellow, el compañerismo y por qué nos volvamos a juntar algún día. Por supuesto a mi gran equipo latino; Chiara y Santi...que gran grupo logramos hacer, ise os quiere!, y a Isa, mi compañera, confesora, y amiga durante estos meses...sin ti Roma no hubiese sido Roma. iGracias a todos por hacer de FAO una de las mejores experiencias de mi vida!

Por supuesto también a la UPM, y en particular a la ETSIAAB, o como yo la llamo, la Escuela. Ya son 15 años desde la primera vez que entré...y desde ese septiembre del 2003 con mis 18 años recién cumplidos me quedé...Me ha brindado las mejores experiencias de mi vida, en especial desde el lado personal. Gracias a todos mis amigos que me he echado estos años, desde los de primero (Omar, Astur, Berme, Rorro, Cocó, Zugui, Mario, Alfon, Bueren, Rachel...), a los últimos. También a mis queridas Soco y Yoli, igracias por las risas, los cafeses y perdón por la lata que os doy! Por supuesto gracias a los lechones (Alba, Miki, Irene, Maya, Claris, Yago, Nashio, Laura, Palo, Leire, Mar, Fahd, Chuzo, Sara, Ana, Blotnik, Nasser, Rulovich,...) por todos estos años de comidas, risas, viajes y cervecitas. También a mi equipazo de Fútbol Armenia por alegrarme cada domingo.

Una mención muy muy especial, sin duda... para ISHTAR. Se podría dejar así, ya que lo dice todo, pero después de casi 15 años creo también merece más palabras. Gracias a Ishtar...he hecho todo. He actuado, bailado, cantado, dirigido, escrito, llorado, gritado, reído (y mucho, pero que mucho mucho), discutido, cortado madera (y cartón, y plástico, y telas), ayudado, equivocado, llevado antenas limpiapipas, sufrido, estresado, dormido, estrenado, reunido, limpiado....Gracias, y mucho, a mis grandes amigos de la carrera...a los Ishtarianos antiguos (Yumpe, Fran, Anita, Espe, Michel, Manzy, Martus, Alicia, Dani, Julio, Verges, Iván, Agueda, Fabioli, Rafa, Almu, Cocó, Roci y Nisi): con vosotros descubrí Ishtar, aprendí a amar el teatro, empezamos todos juntos este gran proyecto, y hoy en día seguimos siendo todo lo amigos que éramos desde el principio...gracias mucho a todos! Manzy; cuando seas director de renombre icontrata a tu gran amigo y vecino!. A las siguientes generaciones (Fanegas, Lara, Assu, Chino, Hues, Paula...), y en especial a 
Yorch, Juli, Dudu, Drokas, Solete (que bien nos lo hemos juntos estos años), Luissao (aunque nos metemos mucho el uno con el otro, los dos sabemos que yo soy mejor) y por supuesto a Layon (gracias por esta amistad tan grande todos estos años). También a las actuales generaciones (iqué bien lo estáis haciendo y cuanto os queda por hacer!), y las que vendrán...porque Ishtar seguirá, como siempre, y servirá para más agradecimientos de Tesis...estoy seguro.

Ya por último a mis amig@s de toda la vida (amigas del Logos), y a María, Felipe, Isma, Andrea (itoda la vida juntos!) y Cris: gracias por todos estos años de amistad. A mi familia; mis abuelos por todo lo que he aprendido de ellos (gracias de corazón a Alejandra, Pascual, Juan y Araceli; que luchadores fuisteis, y cuanto tenemos que aprender de vosotros), mis 4 Tíos, y a mis primas y mi primo, en especial a Sara, que ha sido siempre como una hermana. ¡Por supuesto a Sergio, mi hermano! El cual siempre, siempre, me ha apoyado, ayudado y respetado en todo lo que he hecho, y a Lucía y mis sobris; Marco y Samuel (iCuanto les quiero y cuanto me llenan!).

Para finalizar, esta Tesis está dedicada a mis padres José Luís y Oliva; por enseñarme a ser lo que soy, educarme tan bien y quererme tanto, espero estéis orgullosos. Esta Tesis es para vosotros. Y para ti, Iván, mi compañero de vida, porque sin ti, no soy ni Alejandro, ni Alex, ni Axel, y contigo lo soy todo. Te mereces mucho, espero que te guste. 


\section{SUMMARY}

Global food demand is increasing and changing rapidly because of multiple drivers including population growth, dietary shifts, and economic development. Improving the sustainability of global food systems is a top priority, although many of the efforts that have been made during the last decades have only targeted the production side and supply chain, like increasing agricultural productivity or expanding the agricultural area. Yet, managing food consumption demand, i.e., people's eating habits might deliver not only health, but also important co-benefits from a land, water, and energy perspective. The promotion of responsible consumption, that is, sustainable-healthy diets and reduced food loss and waste, is a key strategy to achieve environmental benefits, sustainable food security, and to enhance public health.

The need to combine supply and demand management approaches to increase global food security in a sustainable manner is an embedded principle of the United Nations' Sustainable Development Goals (SDGs). Among the different goals and targets, SDG 12 focuses on responsible consumption and production in order to achieve environmental benefits and sustainable food security. In addition to the environmental impacts, dietary shifts can cause important health problems such as coronary diseases, diabetes, and obesity. Countries like Spain are making significant efforts to reduce food loss and waste, reverse growing obesity trends, and promote the adoption of healthier food habits like the recommended and traditional Mediterranean Diet. This is recognized as a key strategy to improve the population's health with locally grown, traditional, and seasonal products like fruits, vegetables, olive oil, and fish. Nevertheless, current Spanish consumption patterns (especially among younger generations, and urban and/or lowincome citizens), appear to be shifting towards unhealthier diets.

With a view to connect water, agriculture, environment, food security, nutrition and health, this research aims to investigate the current dietary patterns of Spanish consumers and the possible shifting away that they are doing from a traditional and recommended Mediterranean diet, as well as households' food waste generation, assessing their water and nutritional impacts. Therefore, this Thesis offers three complementary perspectives within SDG 12 , by seeking to fill some knowledge gaps in the water and nutritional impacts of food consumption, and focusing on Spain's households' current food trends, agricultural trade, food waste, and two types of recommended diets.

The first research within the Thesis assesses and compares the water footprint (WF) of two recommended diets; the Mediterranean and American, in order to asses' Mediterranean diet as a sustainable dietary pattern, and to evaluate the water savings of possible dietary shifts in two countries: Spain and the United States (US). The results show that the American diet has a higher total WF in comparison with the Mediterranean one, 
regardless of where the products are produced. In the US, a shift to a Mediterranean diet would decrease the consumptive WF (Green + Blue WF) by 29\% (1252 liters/capita day). Meanwhile, a shift towards an American diet in Spain will increase the consumptive WF also by 29 \% (1277 liters/capita day). The largest share of the WF of both diets is always linked to green water, which implies that the largest impact of dietary shifts is also linked to land use. Grey water in the US is $67 \%$ higher than in Spain. Moreover, only five products account for the larger share of the total WF of the two dietary options in both countries, being meat, fats, oil, and dairy products the food items with the largest WFs.

The second research study within the Thesis focuses on assessing the water-related implications of food consumption and waste among Spanish households' consumers to discern possible policy recommendations. Paying attention also, to the water impacts in Spain and other countries, from which food is imported (i.e. Virtual Water and food trade). The results showed that, for the 12-month period starting on October $1^{\text {st }} 2014$, the Total WF of current consumption in Spain is equivalent to around 3,302 liters/capita day (of which 2,555 are Green, and 400 Blue WF). The products that account for the largest share in the total WF are once again meat, animal fats, and dairy products. Likewise, roughly, $41 \%$ of the total WF linked to household diets is foreign, i.e. imported Virtual Water, and the main countries of origin are Tunisia, Portugal, and France. The Total WF of food waste at households' level is estimated at 131 liters/cap day (of which 97 are Green and 19 Blue WF), equivalent to $4 \%$ of the Total WF of current consumption. In addition, regarding nutritional analysis, the nutrients wasted (because of food waste) per capita year were $40,385 \mathrm{kcal}$, almost $7.5 \mathrm{~kg}$ of macronutrients (proteins, fats, and carbohydrates), 483 grams of fiber and almost 160 grams of micronutrients (vitamins and minerals).

The third research study within the Thesis aims to assess and compare the nutritional and water implications of current food consumption of Spanish households with the recommended Mediterranean diet. Moreover, to calculate their nutritional composition, compared their water footprints, and developed a new methodological approach to assess the nutritional water productivity (i.e. the nutritional value per unit of water embedded). Results show that current Spanish household diet is shifting away from the recommended Mediterranean towards alternative diet containing three times more meat, dairy and sugar products, and 1/3 fewer fruits, vegetables and cereals. The Mediterranean diet is also less caloric, as it contains lesser amounts of proteins and fats, and richer in fiber and micronutrients. Due to the high water content embedded in animal products, a shift towards a Mediterranean diet would reduce about 753 liters/capita day the consumptive water (of which 34 are Blue WF). In addition, the Mediterranean diet has higher water-nutritional efficiency than Current consumption: more energy, fiber, and macro- and micro-nutrients are available per liter of consumptive water used. 
In light of these results, a shift back to a locally produced Mediterranean diet (in which fruits, fish and vegetables account for a larger share of the food intake) and lessening food waste, would deliver greater water savings (753 and 116 liters of consumptive water/capita day, respectively) and nutritional benefits. Consequently, the preservation and further adoption of the Mediterranean diet, as well as minimize food waste in a household level, especially among young and urban generations, is an important goal to be achieved for Mediterranean countries, and potentially other ones. 


\section{RESUMEN}

La demanda mundial de alimentos está aumentando y cambiando rápidamente debido a múltiples factores, entre los que se incluyen el crecimiento de la población, los cambios en la dieta o el desarrollo económico. La mejora de la sostenibilidad del sistema agroalimentario es una prioridad a nivel mundial, aunque muchos de los esfuerzos que se han realizado durante las últimas décadas se han centrado únicamente en el lado de la producción y la cadena de suministro, como el aumento de la productividad agrícola o las hectáreas cultivadas. Sin embargo, el manejo de la demanda de alimentos, es decir, de los hábitos alimentarios, puede brindar no solo beneficios desde el punto de vista de la salud, sino también otros importantes desde el punto de vista del uso de tierra, agua y energía. La promoción del consumo responsable, (dietas sostenibles y saludables y la reducción del desperdicio de alimentos), es una estrategia clave para lograr beneficios ambientales, una seguridad alimentaria sostenible y una mejora de la salud pública.

La necesidad de combinar enfoques de gestión de la oferta de alimentos junto con los de la demanda, para aumentar la seguridad alimentaria mundial de manera sostenible, es un principio integrado de los Objetivos de Desarrollo Sostenible (ODS) de las Naciones Unidas. Entre los diferentes objetivos y metas, el ODS 12 se enfoca en la producción y el consumo responsables. Sin embargo, además de impactos ambientales, los cambios de patrones de consumo pueden causar problemas de salud importantes, como enfermedades coronarias, diabetes y obesidad. Países como España están realizando importantes esfuerzos para reducir el nivel de desperdicio alimentario, revertir los crecientes índices de obesidad y promover la adopción de hábitos alimentarios más saludables, como la recomendada y tradicional dieta Mediterránea. Ésta es reconocida por mejorar la salud de la población con productos locales, tradicionales y de temporada como frutas, verduras, aceite de oliva y pescado. Sin embargo, los patrones de consumo españoles actuales (especialmente entre la generación más joven, urbana y/o de bajos ingresos), parecen estar cambiando hacia dietas poco saludables.

Con el fin de conectar el uso del agua, la agricultura, el medio ambiente, la seguridad alimentaria, la nutrición y la salud, esta Tesis tiene como objetivo estudiar los patrones de consumo actuales en hogares españoles y el posible alejamiento que se está produciendo respecto a la dieta Mediterránea tradicional y recomendada, así como el desperdicio alimentario, evaluando los impactos hídricos y nutricionales que estas prácticas generan. Por lo tanto, esta Tesis ofrece tres perspectivas complementarias dentro del ODS 12, buscando llenar algunas brechas de conocimiento sobre impactos hídricos y nutricionales del consumo de alimentos, centrándose en las tendencias alimentarias actuales de los hogares de España, el comercio agro-alimentario, el desperdicio de alimentos y dos tipos de dietas recomendadas. 
El primer estudio de la Tesis se centra en la evaluación y comparación de la Huella Hídrica $(\mathrm{HH})$ de dos dietas recomendadas; la Mediterránea y la Americana, para estudiar la sostenibilidad de la primera respecto a otras, así como el ahorro de agua de posibles cambios en la dieta en España y Estados Unidos. Los resultados muestran que la dieta Americana tiene una $\mathrm{HH}$ final un $29 \%$ más alta en comparación con la Mediterránea, independientemente de donde se producen los alimentos. En EE. UU., un cambio a una dieta Mediterránea reduciría el uso consuntivo de su HH (agua Verde + Azul) 1252 litros/ persona día. Mientras que un cambio hacia una dieta Americana en España aumentaría el uso consuntivo del agua 1277 litros/ persona día. La mayor parte de la HH final de ambas dietas está siempre vinculada al agua Verde, lo que implica que el mayor impacto de cambios de dieta está relacionado igualmente con el uso de tierra. Las aguas grises en Estados Unidos son un $67 \%$ más altas que en España. Además, solo 5 productos representan la mayor parte del total de $\mathrm{HH}$ de las dos dietas en ambos países, siendo la carne, las grasas, el aceite y los productos lácteos los productos con mayor $\mathrm{HH}$.

El segundo estudio de la Tesis se centra en evaluar los impactos hídricos relacionadas con el consumo de alimentos y su desperdicio en hogares españoles. También se presta atención a los impactos del agua en España y otros países, desde los cuales se importan alimentos (es decir, estudiando el Agua Virtual importada y el comercio de alimentos). Los resultados mostraron que, para el período de 1 año que comienza el 1 de octubre de 2014, la HH final del consumo actual en España es 3.302 litros/ persona día (de los cuales 2.555 son agua Verde y 400 agua Azul). Los productos que representan la mayor parte de la HH final son, una vez más, carne, grasas animales y productos lácteos. Del mismo modo, aproximadamente el $41 \%$ de la $\mathrm{HH}$ final de la dieta en hogar proviene de otros países, es decir, es agua virtual importada, siendo los principales orígenes; Túnez, Portugal y Francia. La HH final del desperdicio de alimentos a nivel hogar se estima en 131 litros/persona día (de los cuales 97 son agua Verde y 19 agua Azul), equivalente al $4 \%$ de la $\mathrm{HH}$ final del consumo. Respecto al análisis nutricional, los nutrientes desperdiciados debido a desperdicios de alimentos por persona y año fueron: 40.385 kcal, casi 7,5 kg de macronutrientes (proteínas, grasas y carbohidratos), 483 gramos de fibra y 160 gramos de micronutrientes (vitaminas y minerales).

La tercera investigación de la Tesis tiene como objetivo estudiar y comparar los impactos hídricos y nutricionales del patrón de consumo actual en hogares españoles con los de la dieta Mediterránea recomendada. Así pues, se calculó su composición nutricional, se compararon sus $\mathrm{HH}$ y se desarrolló un nuevo enfoque metodológico para evaluar la eficiencia nutricional-hídrica (es decir, el valor nutricional por unidad de agua utilizada). Los resultados muestran que el patrón de consumo actual en hogares españoles se está alejando de la dieta Mediterránea recomendada, hacia otra alternativa que contiene tres veces más carne, productos lácteos y azúcar, y un tercio menos de frutas, verduras y cereales. La dieta Mediterránea también es menos calórica, ya que contiene cantidades menores de proteínas y grasas, y más rica en fibra y micronutrientes. Debido a las altas 
HH de los productos animales, un cambio hacia una dieta Mediterránea reduciría 753 litros/ persona día el uso consuntivo de agua (de los cuales 34 son agua Azul). Además, la dieta Mediterránea tiene una mayor eficiencia nutricional-hídrica que el consumo actual: se obtienen más energía, fibra y macro y micronutrientes por litro de agua utilizada.

A la luz de estos resultados, un cambio a una dieta Mediterránea producida localmente (en la que las frutas, el pescado, y las verduras representan una mayor proporción de la ingesta de alimentos) y la reducción del desperdicio de alimentos, producirían significativos ahorros de agua (753 y 116 litros de agua consuntiva por persona día, respectivamente) y beneficios nutricionales. En consecuencia, la preservación y la adopción de la dieta Mediterránea, así como la reducción del desperdicio alimentario a nivel hogar, especialmente entre las generaciones jóvenes y urbanas, es un objetivo importante para los países del ámbito mediterráneo, y potencialmente para otros. 


\section{CONTENTS}

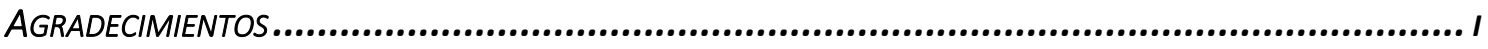

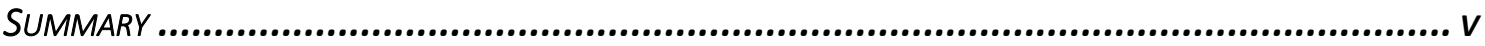

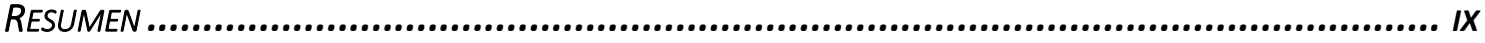

LIST OF FIGURES....................................................................................... XVII

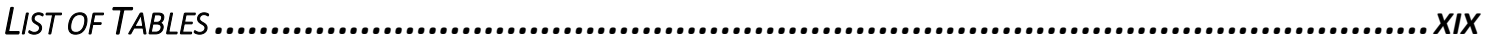

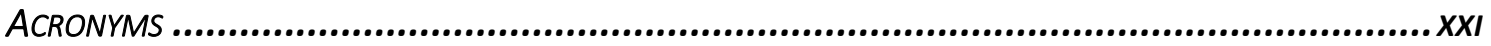

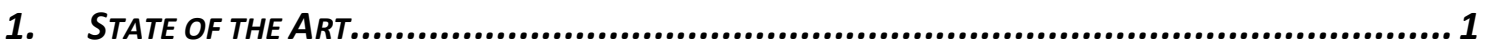

1.1. ENVIRONMENTAL, SOCIAL AND ECONOMIC CONTEXT ........................................... 1

1.1.1. INCREASING POPULATION, URBANIZATION AND CHANGING PATTERNS .......................... 1

1.1.2. AgRICULTURE, ENVIRONMENT AND CLIMATE CHANGE .......................................... 2

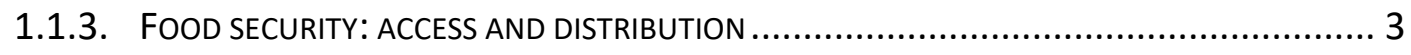

1.2. SOLUTIONS TO THE FOOD AND FEEDING CRISIS ................................................. 4

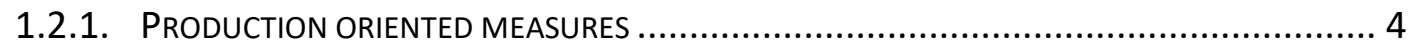

1.2.2. SUSTAINABLE DEVELOPING GoALS (SDGS) ...................................................... 5

1.2.3. SUSTAINABLE FOOD CONSUMPTION: FOOD DEMAND-ORIENTED MEASURES .................. 6

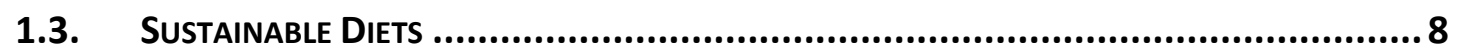

1.3.1. Mediterranean Diet: An eXample of a Sustainable And healthy Diet .................. 8

1.3.2. ENVIRONMENTAL AND WATER IMPACTS OF DIETS ................................................ 9

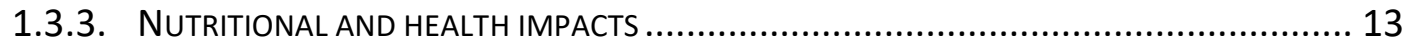

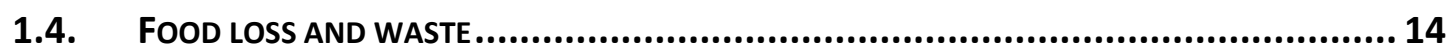

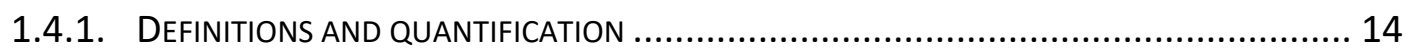

1.4.2. ENVIRONMENTAL AND WATER IMPACTS OF FOOD WASTE ......................................... 16

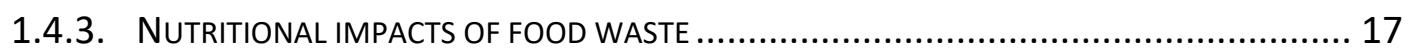

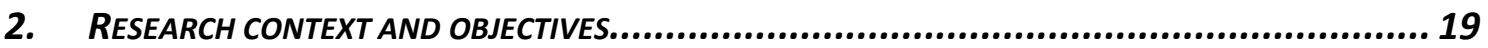

2.1. Problem Statement OVerview AND literature gaPS .................................... 19

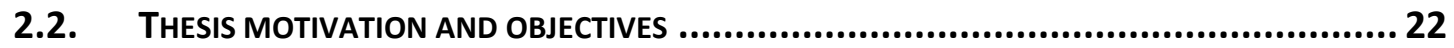

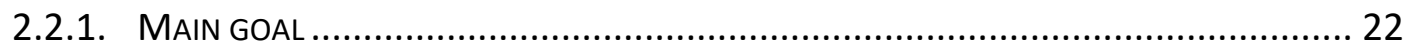

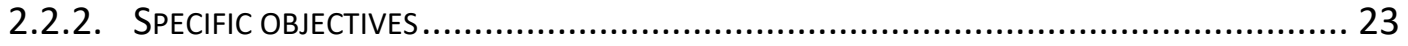

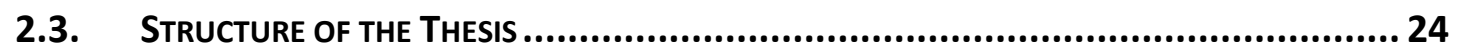

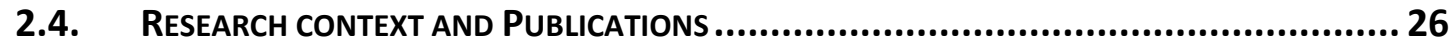

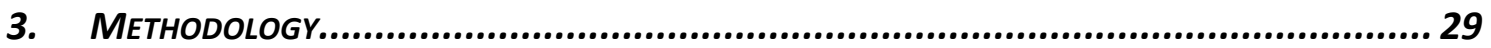

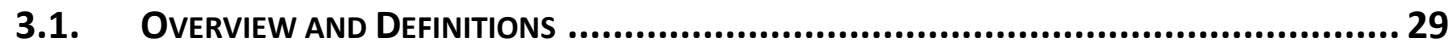

3.1.1. Water Footprint ASSESSMENT ANd Life CyCLE ANALYSIS................................... 29 


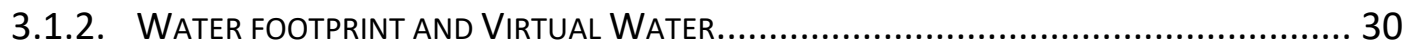

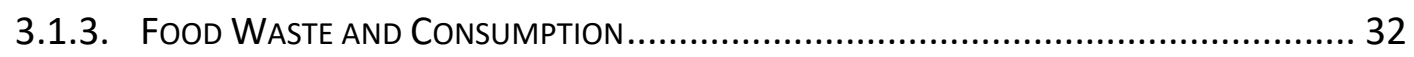

3.2. Evaluation of the water footprint of the Mediterranean and American diets $\mathbf{3 3}$

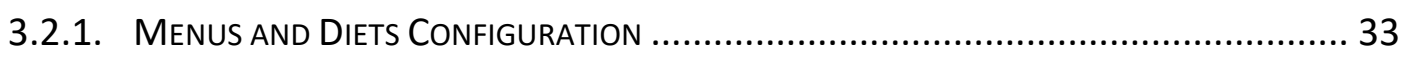

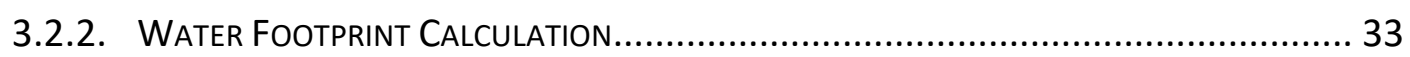

3.3. ASSESSING THE FOOD CONSUMPTION AND WASTE IN SPANISH HOUSEHOLDS, AND THEIR

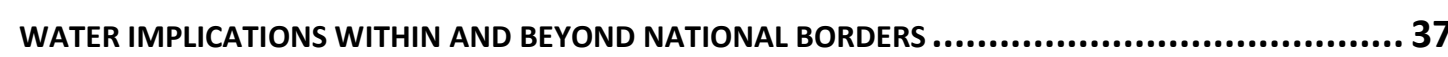

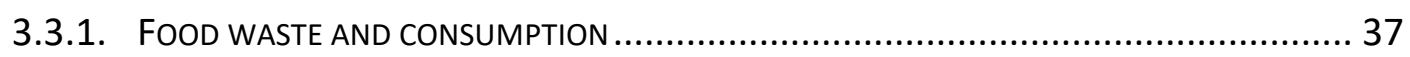

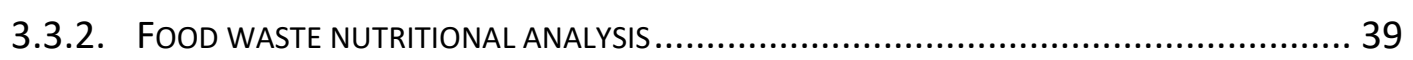

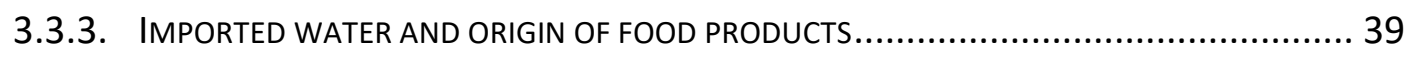

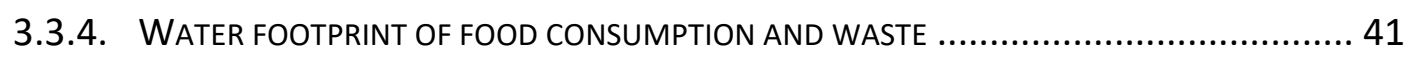

3.4. COMPARISON OF THE MEDITERRANEAN DIET AND CURRENT FOOD CONSUMPTION PATTERNS IN SPAIN FROM A NUTRITIONAL AND WATER PERSPECTIVE............................................. 43

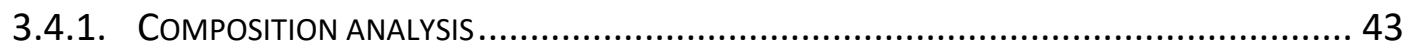

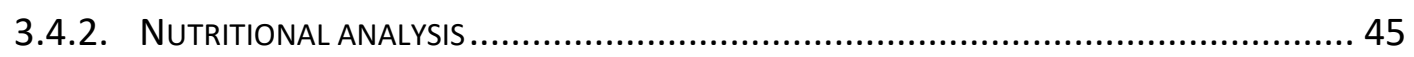

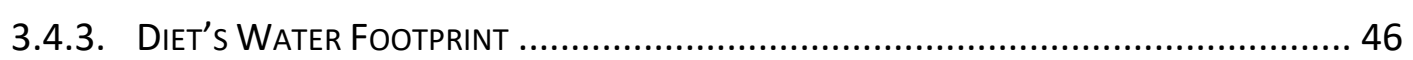

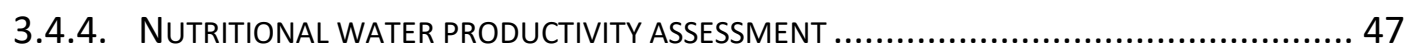

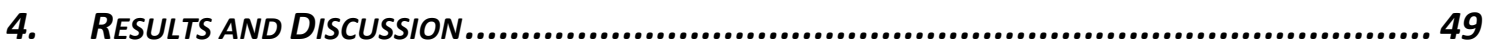

4.1. Evaluating the Water Footprint of the Mediterranean and American Diets... 49

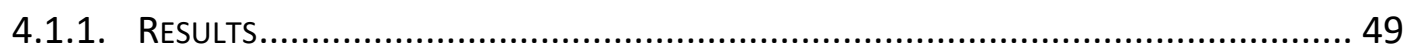

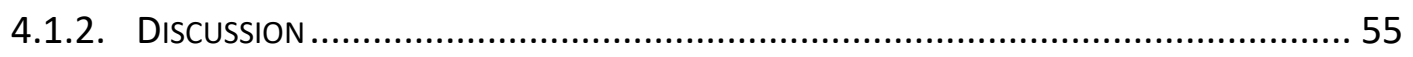

4.2. FOOD CONSUMPTION AND WASTE IN SPANISH HOUSEHOLDS: WATER IMPLICATIONS WITHIN

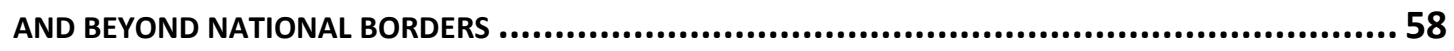

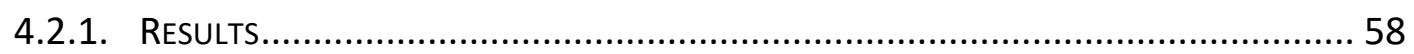

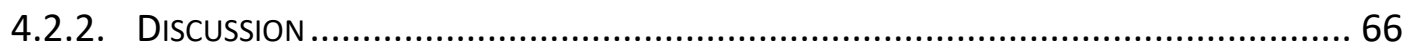

4.3. A comparison of the Mediterranean Diet and Current Food Consumption PATTERNS IN SPAIN FROM A NUTRITIONAL AND WATER PERSPECTIVE ................................... 73

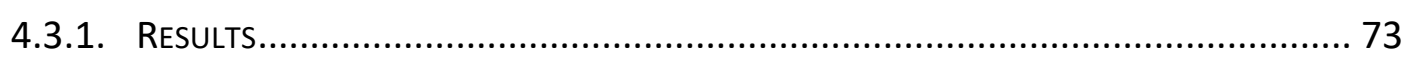

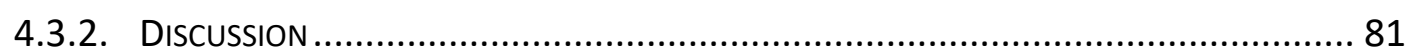

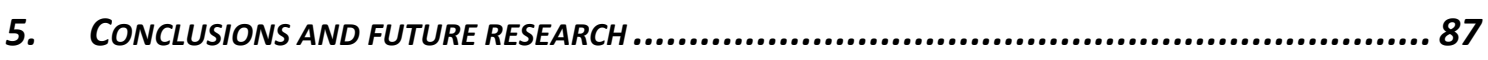

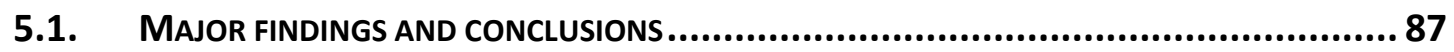

5.1.1. HOUSEHOLDS' FOOD CONSUMPTION IS SHIFTING AWAY FROM HEALTHY, TRADITIONAL,

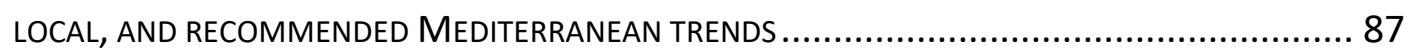

5.1.2. CONSEQUENCES OF THE SHIFTING AWAY FROM RESPONSIBLE FOOD CONSUMPTION PATTERNS (SDG 12) AS MEDITERRANEAN DIET AND A REDUCTION OF FOOD WASTE, IN TERMS OF WATER AND NUTRITIONAL IMPACTS 88 


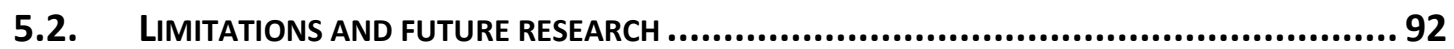

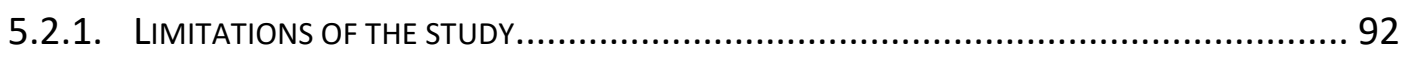

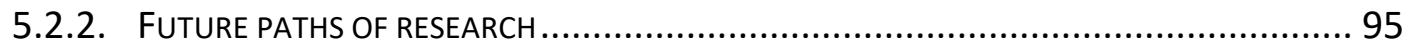

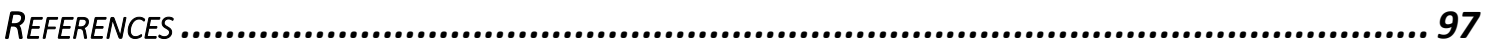

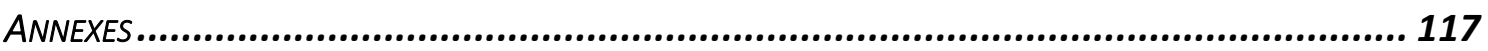

ANNEX I. ALTERNATIVES TO DEVELOP SUSTAINABLE AGRICULTURAL GROWTH: PRODUCTION ORIENTED

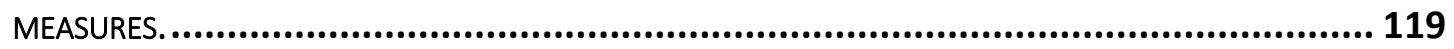

AnNeX II. Sustainable DeVElopMent Goals (SDGs) .................................................... 127

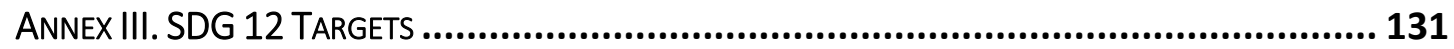

AnneX IV. Weekly Recommended Menus of MediterRanean and American Diets.............. 132

ANNEX V. LINKS TO SUPLEMENTARY MATERIAL OF THE RESEARCH STUDIES .............................. 137 


\section{LIST OF FIGURES}

Figure 1-1. The neW traditional MediterRanean Diet Pyramid applied to a nOWAdays SOCIOECONOMIC CONTEXT. SOURCE: (FUndACIÓN DieTA MEDITERRÁNEA, 2018) AND ITS RESEARCH

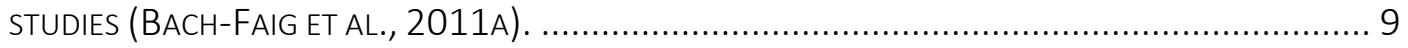

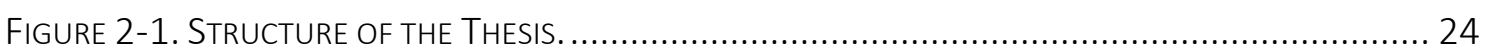

Figure 4-1. GReen, BLUE AND GREY WATER FoOtPRint (WF) FOR WFMENU1, WFMENU2 AND THE total WF diet of the MediterRanean Diet (WFdiet), AND WFMenU1, WFMenu2 and the TOTAL WF DIET OF USDAR DIET (WFDIET), FOR (A) SPAIN AND (B) THE US

Figure 4-2. Characterization of the GREen (A), BLUE (B) AND GREy (C) COMPONENTS OF THE WF Diet of the MediterRanean and USDAR DIETS In SPAIN AND tHe US FOR tHe DIFFERENT PRODUCT GROUPS.

FIGURE 4-3. ANNUAL CONSUMPTION (KG/PERSON) OF ALL FOOD GROUPS AND MAIN PRODUCTS IN SPANISH HOUSEHOLdS (October 2014 - SePtember 2015).

FIGURE 4-4. ANNUAL WASTE (KG/PERSON) FOR ALL FOOD GROUPS AND MAIN PRODUCTS IN SPANISH HOUSEHOLDS (OCTOBER 2014 - SePteMber 2015).

Figure 4-5. ANNUAL IMPORTED WATER (MILLION CUBiC METERS; 1 MILL. $\mathrm{M}^{3}=1 \mathrm{HM}^{3}$ ) WITH RESPECT TO SPANISH HOUSEHOLD FOOD CONSUMPTION (OCTOBER 2014 -SEPTEMBER 2015) BROKEN DOWN BY A) GREEN, B) BLUE, C) GREY AND D) TOTAL VIRTUAL WATER.

FIGURE 4-6 ANNUAL (GREEN, BLUE AND GREY) WATER FOOTPRINT ( $\mathrm{M}^{3}$ /PERSON) FOR DIFFERENT SPANISH HOUSEHOLd CONSUMPTION FOOd GROUPS (OCTOBER 2014 - SEPTEMBER 2015).

FIGURE 4-7. ANNUAL (GREEN, BLUE AND GREY) WATER FOOTPRINT ( $\mathrm{M}^{3}$ /PERSON) FOR DIFFERENT FOOD GROUPS WITHIN SPANISH HOUSEHOLd FOOd WASTE (OCTOBER 2014 - SePTEMBER 2015). ........ 65

FIGURE 4-8. DIETS COMPOSITION DIVIDED INTO 10 FOOD GROUPS AND THEIR PERCENTAGE OF FINAL CONSUMPTION IN SPANISH HOUSEHOLdS FOR A) ESTIMATED MEDITERRANEAN DIET AND B) CURRENT FOOD CONSUMPTION.

Figure 4-9. WATER FOOTPRINT (LITERS/CAPITA DAY) DIVIDED PER COMPONENT (GREEN, BLUE AND GREY) of SPANISH HOUSEHOLD'S CURRENT CONSUMPTION AND MEDITERRANEAN DiET. 77

Figure 4-10. Nutritional Water Productivity (NWP) for Blue and Green water (consumptive use) in Mediterranean Diet in comparison With CurRent Spanish Households Current CONSUMPTION FOR ALL THE NUTRITIONAL COMPONENTS IN NUTRITIONAL VALUES/ LITER OF WATER. 
Figure 4-11. The ShARE OF PROTEINS, FATS, CARBOHYDRATES, AND ALCOHOL IN THE TOTAL ENERGY CONSUMPTION (\%) FOR SPANISH FOOD CONSUMPTION OVER THE LAST DECADES (COMPARISON OF THE DATA REPORTED BY VARELA-MOREIRAS ET AL. (2010) AND OUR RESULTS FOR CURRENT CONSUMPTION AND THE MEDITERRANEAN DIET IN 2014/15).

FIGURE 5-1. FUTURE RESEARCH POSSIBLE STUDIES: SCOPE AND SCALE OF IMPACTS AND FOOD PATTERNS. IN GREY COLOR, WHAT HAS BEEN ADDRESSED IN THE PRESENT THESIS WORK AND WITH NO COLOR THE FUTURE PATHWAYS. 


\section{LIST OF TABLES}

TABLE 2.1. LIST OF PUBLICATIONS, BOOK CHAPTERS AND CONFERENCE PROCEEDINGS OF THE THESIS.

TABLE 3.1. DATA DESCRIPTION AND SOURCES USED FOR THE ASSESSING THE FOOD CONSUMPTION AND WASTE IN SPANISH HOUSEHOLDS, AND THEIR WATER IMPLICATIONS WITHIN AND BEYOND NATIONAL BORDERS ...... 37

TABLE 3.2. DATA DESCRIPTION AND SOURCES FOR THE COMPARISON OF THE MEDITERRANEAN DIET AND CURRENT FOOD CONSUMPTION PATTERNS IN SPAIN FROM A NUTRITIONAL AND WATER PERSPECTIVE. 44

TABLE 4.1. THE FIVE PRODUCTS thAT CONTRIBUTE THE MOST IN LITERS PER CAPITA DAY (LCD) AND \% TO THE GREEN, BLUE, GREY AND TOTAL WFDIET FOR THE MEDITERRANEAN AND USDAR DIETS IN SPAIN.

TABLE 4.2. THE FIVE PRODUCTS THAT CONTRIBUTE THE MOST IN LITERS PER CAPITA DAY (LCD)AND \% TO THE GREEN, BLUE, GREY AND tOTAL WFDIET FOR THE MEDITERRANEAN AND USDAR DIETS IN THE US. ....... 54

TABLE 4.3. FOOd WASTE NUTRITIONAL ANALYSIS: ENERGY (KCAL), PROTEINS, FATS, CARBOHYDRATES, FIBER (ALL IN G), MINERALS AND VITAMINS (MG) PER CAPITA PER DAY (CD) WASTED BECAUSE OF ANNUAL SPANISH HOUSEHOLD'S FOOD WASTE (OCTOBER2014-SEPTEMBER 2015).

TABLE 4.4. ANNUAL IMPORTED VIRTUAL WATER (MILL. M3 = $1 \mathrm{HM} 3$ ) BY ORIGIN WITH RESPECT TO FOOD WASTE IN SPANISH HOUSEHOLDS, (OCT. 2014 - SEPT. 2015).

TABLE 4.5. MULTIDIMENSIONAL NUTRITIONAL ANALYSES (ENERGY, PROTEINS, FATS, CARBOHYDRATES, FIBER, WATER, MINERALS AND VITAMINS) FOR EVERY FOOD GROUP OF CURRENT CONSUMPTION AND MEDITERRANEAN DIET, IN NUTRITIONAL VALUES PER CAPITA PER DAY

TABLE A1.1. WORLDWIDE USE OF CROPS FOR BIOFUELS' PRODUCTION, IN 2005, AND THE 2030 AND 2050 PROJECTION. SOURCE: (ALEXANDRATOS AND BRUINSMA, 2012)

TABle A3.2. TARGETS OF GOAL 12. EnSURE SUSTAINABLE CONSUMPTION AND PRODUCTION PATTERNS. SOURCE: (UNITED NATIONS, 2015, PP. 26-27). 131

TABLE A4.3. Winter RECOMMENDED MENU OF THE MEDITERRANEAN DIET, WITH ALL DISHES AND INGREDIENTS FOR BREAKFAST, MORNING-SNACK, LUNCH AND DINNER FROM MONDAY TO SUNDAY. SOURCE: OWN ELABORATION USING THE FOOD GUIDELINES ELABORATED bY THE MEDITERRANEAN DIET FOUNDATION (FundACIÓN DIETA MEDITERRÁNEA, 2015).

TABLE A4.4. SUMmer RECOMMENDED MENU OF THE MEDITERRANEAN DIET, WITH ALL DISHES AND INGREDIENTS FOR BREAKFAST, MORNING-SNACK, LUNCH AND DINNER FROM MONDAY TO SUNDAY. SOURCE: OWN ELABORATION USING THE FOOD GUIDELINES ELABORATED BY THE MEDITERRANEAN DIET FOUNDATION (FundACIÓN DIETA MEDITERRÁNEA, 2015).

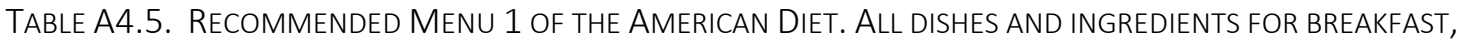
MORNING SNACK, LUNCH AND DINNER FROM MONDAY TO SUNDAY. SOURCE: OWN ELABORATION

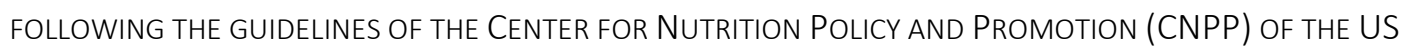
Department of Agriculture (USDA, 2015) AND the study by HAVen et Al. (HAVEN ET AL., 2015). 


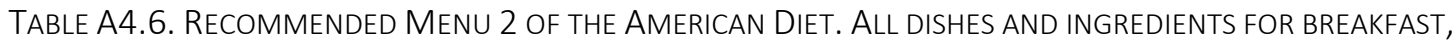
MORNING SNACK, LUNCH AND DINNER FROM MONDAY TO SUNDAY. SOURCE: OWN ELABORATION FOLLOWING THE GUIDELINES OF THE CENTER FOR NUtRITION PoliCy AND PROMOTION (CNPP) OF THE US Department of Agriculture (USDA, 2015) And the study by HAVEn et al. (HAVEn et AL., 2015). 


\section{ACRONYMS}

[Units used in some of the terms in this list that represent variables are presented in chapter 3 , or when they are first mentioned in the thesis]

$\mathrm{CBL} \quad$ Land and Water Division of FAO

CurrentDiet Current Consumption diet in Spanish Households

CEIGRAM Research Centre for the Management of Agricultural and Environmental Risks

FAO Food and Agriculture Organization of the United Nations

FAOSTAT Statistical database of FAO

GHG Greenhouse Gases

g/cd Grams per capita per day

$\mathrm{kcal} / \mathrm{cd} \quad$ Kilocalories per capita per day

$\mathrm{kg} / \mathrm{cy} \quad$ kilogram per capita per year

liters/cd liters per capita per day

LCA Life Cycle Analysis

$\mathrm{m}^{3} / \mathrm{cy} \quad$ Cubic meters per capita per year

MDGs Millennium Development Goals

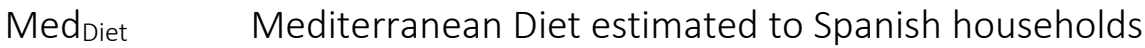

NWP Nutritional water productivity

SDGs Sustainable Development Goals

TAPAS Agro-Environmental Technology for Sustainable Agriculture

UN United Nations

UPM Universidad Politécnica de Madrid

US United States of America

USDA United States Department of Agriculture

USDAr diet American recommended diet from the USDA

VW Virtual Water

WFA Water Footprint Assessment

WF Water Footprint 
WF $\quad$ Water Footprint of a Diet

WFmenu Water Footprint of a Menu 


\section{STATE OF THE ART}

\subsection{ENVIRONMENTAL, SOCIAL AND ECONOMIC CONTEXT}

\subsubsection{INCREASING POPULATION, URBANIZATION AND CHANGING PATTERNS}

World population has been growing exponentially within the last century, especially during the mid and last decades of the $20^{\text {th }}$ century. According to the most recent estimations of the world population, it has reached 7.3 billion in 2015, and nearly 7.6 billion by mid-2017, implying that the world has added nearly one billion inhabitants more within the last twelve years (United Nations, 2017). Also according to this last 2017 revision, the total world's population is projected to increase more than one billion people by 2030, reaching; 8.6 billion in 2030, 9.8 billion in 2050 and 11.2 billion by 2100 (United Nations, 2017).

Furthermore, nowadays we live in a more urban world. Humanity has been experiencing a significant shift to urban living within the last century; whereas in 1900 only a $10 \%$ of the global population were urban dwellers, in the first decade of the 21st century they exceeded 50\% (Grimm et al., 2008). This figure is corroborated by the latest revision of the World urbanization prospects by the United Nations (Brockerhoff and Nations, 1998), which confirmed that in 2018 more than half of the population (55\%) is living in cities and their surroundings and it is projected to increase to 68\% by the year 2050 .

We are facing a new scenario where agriculture and the agrifood system are going to play a key role in the future's world sustainability: due to the increasing world population and rising living standards, some authors estimate that global food production will have to grow substantially. According to the last and revised projections made by FAO taking into account a base year data of 2012, food production will have to increase, in order to reach worldwide food security for all humans, at around 50\% between 2013-2014 and 2050 (FAO, 2017a).

This growing and more urban population will not only create a strong pressure on food supply but also will change food demand in a significant way, with consumption patterns already changing in parallel with the growth of disposable income of about two billion people. As an example, meat demand is growing and will keep on increasing in the next decades, due to increasing welfare levels and increasing demands for animal products in developing countries (Fiala, 2008; Gerbens-Leenes and Nonhebel, 2002; Keyzer et al., 2005; Odegard and van der Voet, 2014). 
Moreover, because of higher disposable incomes and the expansion of world's middle class, consumers are making significant changes in their diets, moving away from basic and non-staple food products as fruits and vegetables towards to higher-value (as fish, meat and dairy products), and usually more processed ones (that may contain high levels of fat, sugar or salt) (FAO, 2017b).

\subsubsection{AgRICULTURE, ENVIRONMENT AND CLIMATE CHANGE}

Given the large footprint that agriculture has on the environment, the question of whether we have the resource base to support growing human consumption demand deserves special attention (Odegard and van der Voet, 2014). Increasing population is placing unprecedented demands on agriculture and natural resources (Foley et al., 2011). At the same time, agriculture is having growing global impacts on both the environment and human health (Tilman and Clark, 2014).

As Odegard and Van der Voet (2014) reported, researchers have been investigating the use and future projections of natural resources demands linked to expanding agriculture. Critical interest has been placed especially in the use of water (Hanjra and Qureshi, 2010; Hoekstra and Chapagain, 2007; Konar et al., 2016, 2011; Rockström et al., 2009; Vanham and Bidoglio, 2015), land (Ewert et al., 2005; Foley et al., 2011, 2005; Ramankutty et al., 2008; Tilman et al., 2002) and fertilizers (Bouwman et al., 2009; Leach et al., 2012).

According to Ramankutty et al. (2018), agriculture is a main major cause of global environmental degradation, and its impacts are expected to increase in the upcoming years due to the intensification of agricultural practices and the expansion of cultivated land. Agriculture globally has already cleared and/or converted: $70 \%$ of grasslands, $50 \%$ of savannas, $45 \%$ of temperate deciduous forests and $27 \%$ of tropical forest biome (Foley et al., 2011; Ramankutty et al., 2008). Moreover, today's major expansion of agriculture is in the tropics, where between 1980 and 2000 more than 55\% of new agricultural land came at the expense of virgin forests, while another $28 \%$ came from disturbed ones (Gibbs et al., 2010).

Converting more land into cultivation and increasing crop yields have been largely promoted in the past (especially in the last decades of the past century) as key solutions to increase food production globally (Matson et al., 1997; Tilman et al., 2002). These production-oriented policies explain why global agricultural area has expanded over $11 \%$ since 1960 (FAO, 2015). Also, it has been the reason why some authors are calling for a new "Green Revolution" or the so-called "sustainable intensification" paradigm, with the objective of not only providing high yield agriculture but also for the restoration of vast acreages of nature, nowadays used as croplands (Ausubel et al., 2013).

Moreover, food systems contribute with 19\%-29\% to global anthropogenic GHG emissions, releasing 9,800-16,900 megatons of carbon dioxide equivalent in 2008 
(Vermeulen et al., 2012). According to these authors, agricultural production (with significant regional variation and including indirect emissions associated with land-cover change), contributes to around $80 \%-86 \%$ of total food system emissions. In global terms, agriculture can be responsible for the total 30-35\% GHG emissions (Foley et al., 2011), mainly because of forest loss and tropical deforestation (Van Der Werf et al., 2009) or livestock production.

Climate change is expected to have also significant impacts on the environment, agriculture, and food production sector. These impacts on food systems are expected to be widespread, complex and geographically and temporally variable, but also influenced by socioeconomic conditions (Vermeulen et al., 2012). Though many regions throughout the world are projected to experience induced reductions in crop yields and food harvested, there are reasons to be concerned in regard to climate change and crop production (Rosenzweig et al., 2014).

Its effects on crop and terrestrial food production are evident in several world's regions, with more regions resulting negatively affected by the impacts of climate change than those experiencing improved conditions (Porter et al., 2014). Also in areas as the Mediterranean one, where rates of warmer and drier climate are projected to be higher than in the past century (Mariotti et al., 2015). This could lead to higher food prices, caused by the inelastic nature of global demand and with significant negative effects in some rural areas (Nelson et al., 2014).

\subsubsection{FOOD SECURITY: ACCESS AND DISTRIBUTION}

The term "food security" has been used over time to mean different things. Originally, it was used to describe whether a country had access to enough food to meet their dietary energy requirements, referring thus to countries' self-sufficiency (Pinstrup-Andersen, 2009). More recently, FAO defined food security as "when all people, at all times, have physical and economic access to sufficient safe and nutritious food to meet their dietary needs and food preferences for a healthy and active life" (FAO, 1996).

Globally, in 2016, the number of chronically undernourished people in the world was estimated to have increased to 815 million, up from 777 million in 2015 (FAO et al., 2017). The last estimation confirms this upward trend; the number of chronically undernourished people in the world in 2017 has increased to 821 million, which represent about one out of every nine people in the world (FAO et al., 2018). At the same time, obesity has more than doubled between 1980 and 2014, with 600 million adults being obese in 2016 (FAO, 2017b), reaching 672 million in 2017 (FAO et al., 2018).

The problem is even more severe in developed countries in Northern America, Europe, and Oceania, where $28 \%$ of adults are classified as obese, in comparison with $7 \%$ or $11 \%$ in Asia or Africa respectively (FAO et al., 2017). 
However, the international food trade is increasing and intensifying over the last decades, making many countries depend on imports as there are not self-sufficient ( $D^{\prime}$ Odorico et al., 2014). Based on these authors, this is occurring due to the increasing globalization of food commodities and diets, and the disconnection between human populations and the natural resources (land and water) that produce them. They also reported in their study that the global trade of food calories has more than doubled between 1986 and 2009, and nowadays around $23 \%$ of the food produced for human consumption is traded internationally.

For Ercsey-Ravasz et al. (2012), since the 1960s decade, global food transport (thus, food trade) has been increasing at an exponential rate, and even faster than food production itself. These authors reported in their study that the total amount that the international agro-food trade network moved from 438 (in 1998) to 1060 (in 2008) billion US dollars.

In Spain, the total imports of agricultural products have increased nine times since the 1960s, while exports have grown more than 7 times to earlies 2010s (Lassaletta et al., $2014 \mathrm{~b})$. These authors also concluded that a change in national consumption patterns is one of the main reasons why Spain is presently not a food and feed self-sufficient country like it was 50 years ago, and has switched to a country with equal levels of net agricultural imports and domestic crop production (measured in terms of nitrogen soil content).

This expansion of global food trade has associated natural resources movements, like the volume water-associated, which has doubled over the past two decades (Chapagain et al., 2006; Dalin et al., 2012). Moreover, approximately $11 \%$ of non-renewable groundwater use for irrigation is embedded in international food trade (Dalin et al. 2017).

\subsection{SOLUTIONS TO THE FOOD AND FEEDING CRISIS}

\subsubsection{PRODUCTION ORIENTED MEASURES}

Meeting future food demand and doing so sustainably is a major challenge for the current and future food production systems (Flachsbarth et al., 2015). Feeding a global and more urbanized population under sustainable and equitable grounds has turned the food "problem" (how much, what type, how or by whom food is produced) into a major concern in recent years (Garnett, 2014). Nonetheless, it seems difficult to face this challenge with the current food production and distribution system, present ongoing consumption patterns and technologies.

Godfray et al. (2010) claimed that changes are required in the way nowadays food is produced, stored, processed, distributed, and accessed, and they have to be as radical as the ones that occurred in the 18th- and 19th-century's Industrial and Agricultural Revolutions and the 20th-century Green Revolution. 
Many of the current efforts and measures are placed together in increasing the sustainability of food production through so-called "sustainable intensification". Since the beginning of 21st century, several authoritative voices that have claimed for sustainable production practices, introduced and developed this "Sustainable Intensification" concept (Foley et al., 2011; Garnett, 2014; Garnett et al., 2013; Godfray et al., 2010; Godfray and Garnett, 2014; Rockström et al., 2017; Tilman et al., 2011, 2002). They propose a set of measures, among which the following ones stand out: (1) establishing a sustainable intensification of agriculture in the future: arable land expansion, closing the "yield gap", "intensification"; (2) increasing aquaculture; (3) improving agricultural resources management; (4) using of biotechnology; (5) decreasing crop lands to animal feeding or biofuels; and (6) improving animal breeding and livestock intensification. Each one of them is a possible solution that has been proposed, studied and described (on their own or combined) attempting to solve the future feed and environmental crisis.

These wide and different strategies are sometimes mutually exclusive, but some others can be put into practice in parallel seeking co-benefits, depending usually on the point of view and model that scientists- professionals consider. A full literature review of all these measures, describing their characteristics and state of the art, can be read in Annex I: Alternatives to develop sustainable growth: production oriented measures.

\subsubsection{Sustainable DeVeloping Goals (SDGs)}

This scientific and technical conscience regarding the sustainable growth of food production is not unique. Under the United Organizations' umbrella starting in 2015, a program on sustainable development has been developed until 2030, including broad issues as poverty, access to water, climate change and sanitation, called the Sustainable Development Goals (SDGs) (United Nations, 2015). More information about the 2030 agenda of the United Nations can be read in Annex II.

The UN Sustainable Development Solutions Network (SDSN, 2018a) promotes solutions for sustainable development, including the SDGs and the Paris Climate Agreement. In their last '2018 SDG Index and Dashboards' report (SDSN, 2018b), they presented a revised and updated assessment of countries' distance to achieve the SDGs, providing additionally a ranking of countries by an aggregate index. The results showed that Spain is in the $25^{\text {th }}$ position of 193 countries, with nearly same index level as Belarus $\left(23^{\text {rd }}\right)$, Slovak Republic $\left(24^{\text {th }}\right)$ or Hungary $\left(26^{\text {th }}\right)$. The first five are, in order: Sweden, Denmark, Finland, Germany, and France.

The Spanish SDSN; called 'Red Española para el Desarrollo Sostenible' (REDS, 2018), is working to implement the SDGs within Spain. Recently, they have published the first report about the implementation of the SDGs in 100 Spanish cities (Sánchez de Madariaga et al., 2018). The results showed that although the overall situation is good, no city 
achieves all the SDGs. Within the analysis, SDG 16 (Peace, justice and strong institutions) is the one that shows the best results with 61 of the total 100 cities reaching the highest score, and no one with the lowest one. Next in the list is SDG 3 (Health and wellbeing), with 46 cities with the highest score, and only three with the worst.

Finally, the Spanish Government has recently (July 2018) presented its National Voluntary Report to the UN of its action plan for the 2030 agenda (Gobierno de España, 2018). This Plan analyzes the situation of the SDGs in Spain and the actions through which the Agenda will be implemented. Moreover, the Spanish Government also has recently appointed a High Commissioner for the 2030 Agenda to coordinate the actions of the Government for the implementation of the SDGs.

\subsubsection{SUSTAINABLE FOOD CONSUMPTION: FOOD DEMAND-ORIENTED MEASURES}

Beyond any productivity improvements (as shown previously and fully described in Annex I), these measures oriented towards increasing the efficiency of food production need, however, to be combined with policies and strategies aimed at improving food consumption patterns i.e. improved management of food demand (Foley et al., 2011; Garnett et al., 2013). Enhancement of consumption patterns and the promotion of healthier and sustainable diets will be of major importance to achieve positive environmental effects (Carlsson-Kanyama and González, 2009; Tilman and Clark, 2014).

Recently, several studies have analyzed and recognized the importance of diets in future food security and sustainability (Jalava et al., 2014; Rockström et al., 2009). Moreover, changing our food consumption patterns and reducing food waste are crucial for achieve a sustainable intensification (Foley et al., 2011; Garnett et al., 2013; Godfray et al., 2010; Godfray and Garnett, 2014; Royal Society (Great Britain), 2009).

The need to combine supply and demand management approaches to increase global food security in a sustainable manner is an embedded principle of SDGs, and of, the European Commission Action Plan for a circular economy in Europe (European Commision, 2015).

Among the different goals, SDG 12 on "Responsible consumption and production" attempts to ensure sustainable production and consumption patterns (including halving food loss and waste throughout the entire food chain) in order to achieve environmental benefits and sustainable food security (United Nations, 2015).

One of the facts that the United Nations considers developing this goal is that households (i.e., consumers, in the final part of the food chain) have a high influence in several and different environmental impacts through their dietary choices and habits. For this goal, different stakeholders must be involved; from producer to final consumers. Changing their behavior and consumption patterns is possible by engaging them through 
awareness-raising and education on sustainable consumption and lifestyles (United Nations, 2018). All targets within this SDG 12 are fully described in Annex III.

In line with sustainable consumption and reducing food waste is the term and related actions of "Circular Economy". This notion can be defined as a regenerative system in which resource input and waste, emission, and energy leakage are minimized by closing material and energy loops (Geissdoerfer et al., 2017). For Stahel, (2015), the circular economy turns goods that are at the end of their life into new resources, by closing loops in industrial ecosystems or reducing waste. Its origin is mainly based in ecological and environmental economics and industrial ecology, and in the last years has been receiving increasing attention worldwide as a way to change the current production and consumption model (Ghisellini et al., 2016). The review made up by these authors highlighted that the circular economy claims to increase resource use efficiency with a special focus on waste (urban and industrial) to achieve a triple economy, environment, and social balance.

As mentioned earlier, the European Commission presented in 2015 an Action Plan for a circular economy in Europe (European Commision, 2015) that includes 54 measures on which it is necessary to act in the next five years. The aim of this Action Plan is to turn Europe into a more resource use efficient society, with less waste production with the maximum guarantee for health and environment. The Spanish Government will also present by the end of 2018 or beginning 2019 an Action Plan for a circular economy within the country.

These measures promoted by the United Nations or the European commission relied on a more efficient food demand's management in order to achieve environmental benefits. That is, promoting practices that increase food demand management efficiency and involve all stakeholders within the food chain, and especially the final part (i.e. consumers). Nevertheless, what does "sustainable diet" exactly mean? How can it be defined? In order to clarify this term, the FAO $(2010$, p. 7) definition is widely used and accepted, which is:

"Sustainable Diets are those diets with low environmental impacts which contribute to food and nutrition security and to a healthy life for present and future generations. Sustainable diets are protective and respectful of biodiversity and ecosystems, culturally acceptable, accessible, economically fair and affordable; nutritionally adequate, safe and healthy; while optimizing natural and human resources".

For Johnston et al. (2014), the concept of sustainable diets presents an opportunity for the present to successfully advance and achieve the sustainability objectives. These authors concluded in their review that agriculture, health, environmental, socioeconomic and culture are the major determinants of the definition and application of sustainable diets. In addition, they pointed out that more and better measurements and indicators must be developed in the future to assess how diets can influence the environment. 


\subsection{SUSTAINABLE DieTS}

\subsubsection{MediterRANeAn Diet: AN EXAMPLE OF A SUStaINABLE AND HEALTHY DIET}

A continuous example among research studies of sustainable diets is the analysis of (and adherence to) the Mediterranean diet. Much of this work reported has also considered the Mediterranean diet as a prototype of a healthy consumption pattern (Aleksandrowicz et al., 2016; Davis et al., 2016; Hallström et al., 2015; Rosi et al., 2017; Tilman and Clark, 2014; Ulaszewska et al., 2017; Van Dooren et al., 2014), comparing it with some others not so allegedly healthy, like the current western, or meat-based food patterns. All these studies have reported also how the Mediterranean Diet has been related to other presumably healthier ones, as pescetarian or vegetarian.

In fact, the Mediterranean diet has been recognized in many countries as a key strategy to improve a population's health with local, traditional and seasonal products (Bach-Faig et al., 2011a; Bonaccio et al., 2012). Also, it has been recognized by UNESCO as a cultural World Heritage (UNESCO, 2016), and was selected by FAO 20 years ago to develop a methodological approach to assess sustainability across different agro-ecological zones (Smith and McDonald, 1998).

In the last years, the Mediterranean Diet Foundation (Fundación Dieta Mediterránea, 2018), supported by scientific evidence (Bach-Faig et al., 2011a), has been working in the new Mediterranean Diet pyramid; its composition, analysis, and description. As the Foundation explains (Fundación Dieta Mediterránea, 2018): "the traditional Mediterranean diet pyramid has been updated to suit current lifestyles by initiative of the Mediterranean diet foundation and in collaboration with many international organizations, a group of experts from various disciplines, from nutrition to anthropology, sociology to agriculture, have agreed on this new representation enriched to include qualitative elements".

This new pyramid, published by Bach-Faig et al. (2011a), is presented in Figure 1-1. As the authors indicate, the traditional Mediterranean diet has been the "heritage of millennia of exchanges of people, cultures, and foods of all countries around the Mediterranean basin. It has been the basis of food habits during the twentieth century in all countries of the region, originally based on Mediterranean agricultural and rural models" (Bach-Faig et al., 2011a, p. 2274). By applying the new social and economic context to this traditional food pattern, these authors developed a new graphic representation with updated recommendations of the lifestyle, dietary, sociocultural, environmental and health way of life in Mediterranean region.

The new pyramid describes which products ought to be eaten in a major proportion (in its base) and which others only in moderate amounts (in the superior level), all based on the traditional Mediterranean Diet pattern. It describes also the number of servings of 
each food product and/or group per day (or week). Thus, in the base are food groups such as fruits, vegetables, cereals, and olive oil, and in the upper one; white meat, vegetable fats, red or processed meat, and finally, sweets products.

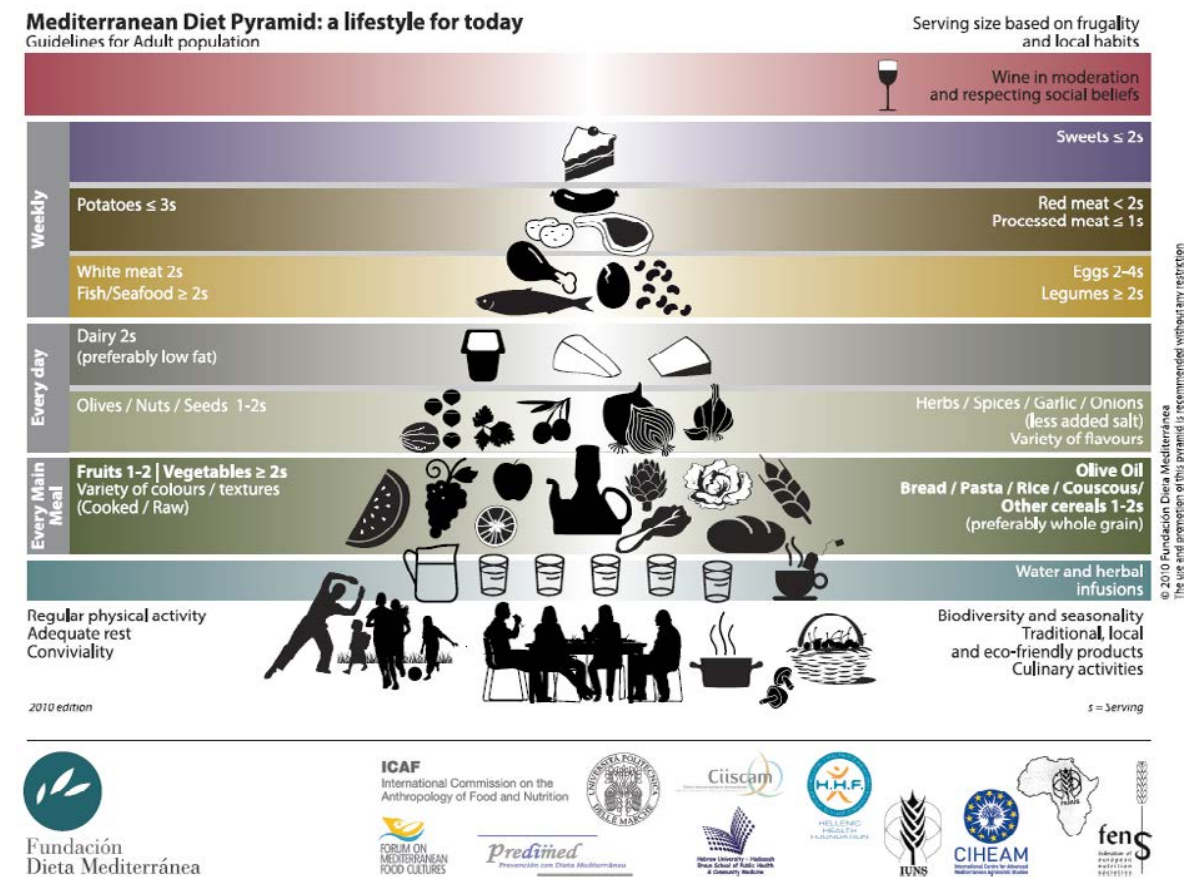

Figure 1-1. The new traditional Mediterranean diet pyramid applied to a nowadays socioeconomic context. Source: (Fundación Dieta Mediterránea, 2018) and its research studies (Bach-Faig et al., 2011a).

\subsubsection{ENVIRONMENTAL AND WATER IMPACTS OF DIETS}

Despite all institutional and international measures and scientific works promoting a sustainable and responsible consumption as the Mediterranean diet, a question arises about how the choice of consuming different diets can produce significant environmental impacts. Some questions are: how can consumers adopt certain consumption patterns with major environmental benefits? How can they be measured? Can we differentiate between diets based on their sustainability performance?

These and further questions have been investigated by researchers in recent years in order to assess the relationship between the adoption of different diets and their environmental impacts.

Previous literature shows that larger environmental impacts are originated because of diets intensive in animal products-based in comparison to less meat-based and vegetarian ones, especially related to GHG emissions, water and land (Carlsson-Kanyama and González, 2009; Davis et al., 2016; Donati et al., 2016; J. Gephart et al., 2016; Heller 
and Keoleian, 2015; Jalava et al., 2014; Machovina et al., 2015; Harold J. Marlow et al., 2009; Pimentel and Pimentel, 2003; Tilman and Clark, 2014; Tukker et al., 2011; Van Dooren et al., 2014; Vanham, 2013; Vanham et al., 2013a, 2013b,; Westhoek, 2014).

A systematic review of 14 research studies assessing environmental impacts of dietary change made by Hallström et al. (2015) shows that the potential through a dietary change to reduce GHG and land use demand can be substantial (50\%). These authors remarked that this potential is mainly dependent on the amount of red meat (especially from ruminant animals) included in diets, and replacing it with pork and poultry ones can reduce GHG emissions and land use demand up to $35 \%$ and $40 \%$ respectively. If red meat were changed with plant-based products, reductions would be up to $60 \%$ in land use demand.

Another systematic review of a total of 210 scenarios extracted from 63 types of research of GHG emissions, and land and water use impacts in dietary change were made by Aleksandrowicz et al. (2016). They found that among 14 different dietary options the ones that were more sustainable (identified by authors as plant-based diets, or with fewer meat options as the Mediterranean or New Nordic one) had major environmental benefits. These diets generated reductions of $70-80 \%$ in GHG emissions and land use, and $50 \%$ of water use. They concluded that shifting from a typical actual western diet to a more sustainable one can bring both health and environment benefits. The vegetarian diet was the one which accounted for the largest environmental and health benefits.

In fact, some other authors also concluded that the Mediterranean diet is much appreciated for its lower environmental impacts in relation with other meat-based diets (Capone et al., 2014; Sáez-Almendros et al., 2013).

Another similar study, by Baroni et al. (2007), compared different environmental impacts (damages to human health, ecosystem quality, and primary resources) from four different weekly balanced diets (current Italian, omnivorous, vegetarian, and vegan) and two methods of production (conventional and organic agriculture). The results obtained by the authors highlighted that the current Italian diet (with conventional production) has the greatest impact on the environment, while the vegan one in organic agriculture the lower one. They also concluded that within the same method of production, diets with a greater consumption of animal products have higher environmental impacts.

For Pimentel and Pimentel (2003b), a meat-based average American diet requires more energy, land and water resources than a lacto-vegetarian diet, although both of them requires significant non-renewable fossil energy quantities. Also, Tukker et al. (2011) reported that reduced meat consumption scenarios (replacing red meat about $40 \%$ by chicken, seafood and cereals), implied changes of approximately $8 \%$ in environmental impacts (climate change, ozone depletion or terrestrial acidification among others) in Europe. 
Donati et al. (2016) concluded in their experiments with dietary information collected from 104 young people in Parma (Italy), that a sustainable diet (with a large share of planted share consume) lead to $9 \%$ reduction in water consumption and $26 \%$ less land needed compared to the current one. Likewise, Gephart et al. (2016) evaluated four footprints (carbon, nitrogen, water, and land) of nutritional and population data for the United States, and their results showed that those diets with livestock products have higher footprints than the ones containing vegetal products and seafood.

By using biophysical models and methods, Westhoek (2014) predicted the large-scale consequences in the European Union of replacing 25-50\% of animal-derived foods (beef, dairy, pig meat, poultry, and eggs) with higher intake of cereals. They concluded that such reduction of animal products consumption could lead to reductions of $90 \%$ of forage grown on arable land (23\% cropland use per capita), 40\% nitrogen emissions and $250 \%$ GHG emissions in the EU.

Moreover, Machovina et al. (2015) suggested also three possibilities in order to conserve biodiversity around the world; changing animal-based product for plant-based ones or reducing demand for the livestock ones, replacing bush meat and ruminant sources with other more sustainable such as pork, seafood or poultry and finally ending single-product and intensive livestock production to conserve energy and nutrients. Lastly, Marlow et al. (2009) also reported higher environmental impacts for non-vegetarian vs. vegetarian Californian quantified studies for 11 food items. The non-vegetarian diets required 2.9 times more water, 2.5 more energy, and 13 times more fertilizer.

Regarding the individual assessment of water in diets, in the course of the last years, some methodologies, including the water footprint assessment (WFA) (Hoekstra et al., 2011), and the life cycle analysis (LCA) (Boulay et al., 2013), have been developed to assess only the impacts on water resources linked to food production and consumption patterns. Both approaches are more explained in Chapter 3.1. Methodology Overview.

Jalava et al. (2014) compared the WF of current global consumption patterns with diets containing low contents of animal products. The authors reported that simple dietary changes by lessening meat consumption would decrease the agricultural green water footprint (thus the agriculture land demand), while the savings in blue water would not be so largest in some countries.

Furthermore, a large number of studies addressing the issue of diets and water impacts relied on the methodology proposed by the WFA. Yang and Cui (2014) compared the WF of food consumption for worldwide diets (from 1961 to 2009) and they concluded that potential water savings through agricultural practices developments could balance population growth and dietary consumption changes.

Vanham et al. (2013b) compared the WF of current consumption patterns with healthier and vegetarian diets in Europe and found that improving diets might result in reductions of the diet's WF between 974 and 1611 liters per capita day, equivalent to savings of 
$23 \%-38 \%$. These authors also concluded that the consumption of animal products accounts for the largest share (46\%) of the WF linked to the prevailing European diets.

Capone et al. (2013), analyzed the WF of the current Italian diet and compared it with a recommended one (similar to the Mediterranean diet). They concluded that the current diet was $69.9 \%$ higher than the recommended (in terms of WF), so an adherence to this last one from 2006 to 2011, would have allowed saving an amount of water that can allow for covering total personal consumption of freshwater for more than three years in Italy.

Other studies comparing three European diets (current, healthy and vegetarian) across four European areas (west, north, south, and east) showed that in all zones adopting healthy and vegetarian diets could lead to substantial WF reductions (up to 41\%) (Vanham et al., 2013a). In their last study, Vanham et al. (2018) analyzed in three European countries (Germany, France, and the UK) the WF of their food consumption, concluding water savings within a range of $11-35 \%$, and $33-55 \%$ of healthy diets containing less meat or pescetarian-vegetarian respectively, in comparison with their actual consumption.

A recent study by Jalava et al. (2016) assessed the potential water saving of combining a change of diet and food loss reduction. Regarding only a change to dietary recommendations, one containing fewer animal products (only the $25 \%$ of the total protein intake were from animal origin) would result in savings of $11 \%$ Blue WF and $18 \%$ Green WF, being Europe the second region with the highest Blue WF savings (up to 30\%).

Additional researches have addressed the water footprint linked to shifts from recommended diets across various countries like the United States (Pimentel and Pimentel, 2003), Austria (Vanham, 2013) or Spain (López-Gunn et al., 2012). Different consumption patterns at the city level in the Netherlands (Vanham et al., 2016b), Mediterranean region (Vanham et al., 2016a) or Nordic countries (Vanham et al., 2017) also focus on similar issues.

In contrast, there are also several studies where no differences between plant based or animal based diets have been reported (Macdiarmid et al., 2012; Tom et al., 2016; Ulaszewska et al., 2017; Vieux et al., 2012). Ulaszewska et al. (2017) assessed the GHG emissions impact using an environmental hourglass approach based on LCA (Life Circle Analysis) in two recommended diets: the Mediterranean and new Nordic model. They showed that consumption of fruits and vegetables have a similar environmental impact than those high protein foods. Moreover, eggs, legumes, and fish also could have impacts up to twice as high as meat.

In another study (Tom et al., 2016), measured energy use, blue water footprint, and GHG emissions impacts associated from shifting from a current US diet to three different USDA's recommendations scenarios: reducing caloric intakes from "normal" weight, and shifting food with lower intake of meat, sugar and fats, and both together. They found 
increases in cumulative energy use (38\%), blue water footprint (10\%), and GHG emissions (6\%) under the last scenario.

Another research by Rosi et al. (2017) comparing the environmental impacts of three omnivorous, ovo-lacto-vegetarian and vegan diets in 153 Italian adults by monitoring food intake during one week drew similar conclusions. Although the animal-based diet had the highest impact for each environmental indicator evaluated, no differences were found for ovo-lacto-vegetarians and vegans diets. Moreover, they also concluded that some vegetarians or vegans have higher environmental impacts than some omnivores and that the vegetarian option was not associated with lower footprints compared to the vegan one, maybe because of the higher food intake and highly processed plant products in the vegan one.

As explained above, literature has analyzed and compared different consumption patterns and evaluated their environmental impacts. Nevertheless, the key issue is how consumers can become more aware of the environmental impacts linked to their food choices. To help consumers, Leach et al., (2016) proposed environmental impact food labels using three types of footprint calculation (footprint weight, sustainability measures, and \% daily value) for carbon, nitrogen, and water footprints, in order to help them compare across and within food products and consume more sustainable and environmentally- friendly diets.

Peschel et al. (2016) found that only $20 \%$ of consumers from online surveys in Canada and Germany were ready and conscious to adopt footprint labels in their diet choices, but another $10-20 \%$ could be more conscious by marketing campaigns. Other authors (De Boer et al., 2014) proposed and evaluated the implications of having "Meatless days" or "less but better" consumption patterns, to have more sustainable diets. Finally, for Macdiarmid et al. (2016), dietary changes will be difficult because public opinion around eating meat is still associated with important personal, social and cultural values.

\subsubsection{NUTRITIONAL AND HEALTH IMPACTS}

Nevertheless, not only sustainability is a key role for the future, but also health impacts because diets are in close relation to human health. In much of the developed world, dietary shifts are causing important health problems such as coronary diseases or diabetes, and in the non-developed ones, inadequate diets are making big nutritionally deficiencies on many people (Tilman and Clark, 2014).

The prevalence of overweight and obesity has increased and accelerated worldwide since 1980 (Stevens et al., 2012). In 2010, both of them were estimated to cause 3.4 million deaths, so global and national action to combat them is urgently needed (Ng et al., 2014).

In Western Europe in 2013, according to these last authors, the prevalence of overweight and obesity in boys (under 20 years old) was 24.2\%, in men (more than 20 years old) 
$61.3 \%$, in girls (under 20 years old) $22 \%$, and in women (more than 20 years old) $47.6 \%$. The results from the same study showed that in Spain these were $27.6 \%$ for boys, 62.3 for men, $23.8 \%$ for girls, and $46.5 \%$ for women. This means that the Spanish population has a greater prevalence index to overweight and obesity than the average Western European countries.

These results are consistent with the ones of Papandreou et al. (2008), where they reported that dietary shifts are placing Mediterranean societies at high risk of obesity regardless of geographical location or income, showing the highest levels among Europeans. Spain, in particular, stands among the top ten countries in the broader Europe region in terms of both adult obesity and overweight (27\% and $62 \%$ of the total population respectively) and the prevalence is on the rise (WHO, 2013).

This circumstance is driving national health and/or food agencies to campaign in favor of investing public funds to raise awareness among citizens about the importance of adopting healthier food habits. Countries like Spain are placing large efforts to reverse the growing obesity problems and involving different public institutions in the promotion of the Mediterranean diet (Bach-Faig et al., 2011a; Sáez-Almendros et al., 2013).

Other countries facing serious obesity problems, like the United States of America (US), are also investing large efforts to reverse this trend (Haven et al., 2015). In fact, the United States Department of Agriculture (USDA) in an attempt to raise awareness among consumers has elaborated several national dietary guidelines and recommended diets (Haven et al., 2015; USDA, 2015).

Likewise, preliminary normative work has been reported that would allow for linking nutrition, agriculture, and environment, e.g. the nutritional water productivity (NWP) concept by Renault and Wallender (2000), with yet limited implementation and limited methodological development. These authors defined NWP as the nutritional content of a crop per volume of water consumed. With this index, they linked crop productivity, food production and (mal) nutrition by applying the water productivity concept to nutritional values.

\subsection{FOOD LOSS AND WASTE}

\subsubsection{DEFINITIONS AND QUANTIFICATION}

Food waste can be defined as all losses occurring during any stage of the production chain or during consumption, including the household consumer level (Kummu et al., 2012). The importance of avoiding food waste and investigating at which stage of the chain this occurs are obviously related. Therefore, the need to assess global food waste in today's society has grown over the last decade. This has been partly driven by the need to link 
waste and global malnutrition and highlight its scale (Parfitt et al., 2010), but also to reduce all natural resources (water, land...) used and GHG emissions associated with the waste products.

However, research has been scant so far. Available studies usually differ with respect to the part of the food chain on which they focus (Parfitt et al., 2010). Taking into account the entire food chain, some authors have estimated food losses ranging from 30\% to 50\% (Gustavsson et al., 2011; Lundqvist et al., 2008). This amounts to nearly 1.3 billion tons per year worldwide (Gustavsson et al., 2011).

Reasons for food waste are diverse. Some of them may be remedied by consumers' awareness (sensitization) and/or changing food consumption patterns, but others are structural. Some authors also emphasize stark differences between developing countries and industrialized nations. In the first ones, food losses tend to occur at the beginning of the chain (i.e., agriculture and industry), which can be explained because of the lack of infrastructure. On the other hand, in the industrialised countries although food losses and waste can also occur in the first stages (mainly in agriculture and because of quality reasons), most of them happen at final stages; wholesaling, retailing and consumption stages (Lundqvist et al., 2008; Parfitt et al., 2010; Ridoutt et al., 2010), putting the focus on consumption and sociocultural behaviors.

At the post-consumer level (food waste on a household basis), a review conducted by Parfitt et al. (2010) found that there were few available studies (none in developing countries) and that the reported quantitative data were hard to compare because they were measured according to different methodologies and definitions. Nevertheless, some national assessments have been conducted recently in countries like Turkey (Pekcan et al., 2006), the Nordic countries (Gjerris and Gaiani, 2013), the USA (Jones, 2014; Koester, 2013) and the UK (Quested et al., 2012; WRAP, 2009).

In addition, national governments are taking into account this issue. Some examples are in Spain, where the Spanish government has implemented the so-called "More Food, Less Waste" program over the last few years in a significant effort to quantify all food waste in households, industry, and farm levels (Ministerio de Agricultura Alimentación y Medio Ambiente, 2015). Also in the UK, where the Waste and Resources Action Programme (WRAP) launched the "Love Food Hate Waste" campaign in 2007 to help deliver practical ways to reduce food waste (Quested et al., 2012).

Especially during the last years, public and institutional initiatives, like the circular economy policies from the European Commission or the United Nations SDGs, have been focusing to reduce food loss and waste. Regarding the Sustainable Development Goals, Target 3 of SDG 12 compromised to halve by 2030 per capita global food waste at the retail and consumer levels and reduce food losses along production and supply chains, including post-harvest losses (United Nations, 2018). 


\subsubsection{ENVIRONMENTAL AND WATER IMPACTS OF FOOD WASTE}

Apart from the problem related to food safety, what environmental problems does food waste generate? Which effects does the fact of throwing or dismissing so much food has on GHG emissions, nutrition, or on the natural resources ( such as water use)? Would it be possible to obtain significant environmental and nutritional improvements reducing food waste and loss?

For Garnett (2011), addressing the growing problem of food waste issue could offer considerable theoretical scope for GHG emissions reductions, though all food that is lost or wasted within the food chain represents a waste of all emissions generated during the course of agricultural products production and distribution. Moreover, reducing waste (at the source by 20\%) and enhanced food use efficiency could also save more food than the annual increase in total food production in the US (Dou et al., 2016).

National assessments of food waste environmental issues (mainly regarded GHG emissions) have been conducted recently in countries like the UK (Quested et al., 2012, 2013), Australia (Reutter et al., 2017), the Nordic countries (Brancoli et al., 2017; Engström and Carlsson-Kanyama, 2004; Katajajuuri et al., 2014; Scholz et al., 2015), the USA (Hall et al., 2009; Venkat, 2012), China (Song et al., 2015) and Switzerland (Beretta et al., 2013). Also at European (European Commission, 2010) and worldwide (Alexander et al., 2017; Grizzetti et al., 2013; Kummu et al., 2012) levels.

The Waste and Resources Action Programme (WRAP) has been studying food waste in the UK since 2007. In their 2012 research (Quested et al., 2012) with 1800 British households, they found that the GHG emissions associated with the 7 million tons of food and drink wasted accounted for approximately 17 million tons of $\mathrm{CO}_{2}$ equivalent.

Moreover, Quested et al. (2013) highlighted that large environmental benefits come from preventing waste at household level due to its potential to reduce the energy, water and other resources used to grow, produce, transport and cook the food.

In a research by Reutter et al. (2017), authors used the life cycle analysis framework of an environmentally-extended input-output methodology to assess the environmental and socioeconomic impacts of food waste in Australia. Their results show that Australian food waste represents $9 \%$ of the total water use, with final consumers being responsible for wasting more than half of it. These results are similar to the ones reported by Liu et al. (2013), who assessed that the total WF related to food losses and waste in China was around $14 \%$ of China's total water footprint $\left(135 \pm 60\right.$ billion $\left.\mathrm{m}^{3}\right)$. Also, authors like Lundqvist and Unver (2018) point to the importance of reducing food loss and waste and tackling the high prevalence of overeating and obesity in reducing water risks and curbing greenhouse emissions as a part of a holistic approach. 
Food waste also contributes directly to excess fossils fuels (Hall et al., 2009). For these authors wasted food in the USA accounted for 300 million barrels of oil per year representing $4 \%$ of the total US oil consumption. They reported that the increase of $50 \%$ of food waste since 1974 and the obesity epidemic were effects of the increased of availability and marketing of cheap and ready food.

A big study in China households was held by Song et al. (2015), where they quantified the carbon, water, and ecological footprints of 17,110 family members of Chinese households, covering 1935 types of foods. The total amount of average annual food waste per household was $58 \mathrm{~kg}$ (16 kg per capita, 21 million tons in all China). This food waste was equivalent to $40 \mathrm{~kg}$ of $\mathrm{CO}_{2}$ emissions, $18 \mathrm{~m}^{3}$, and $173 \mathrm{gm}^{2}$ for the carbon, water, and ecological footprints, respectively. These authors also reported that even food waste of animal-derived food was only $13 \%$ of the total, they accounted for the $30 \%, 44 \%$, and $27 \%$ of the total embedded carbon, water, and ecological footprints, respectively.

Another study in a Swedish supermarket (Brancoli et al., 2017), after categorizing and quantifying the waste (22.5 tons of wasted food within a year) and assessing nine different environmental impacts, showed that bread (in three of nine categories) and beef meat (the remaining six categories) contributed the most to the final environmental footprint.

An earlier study also launched in Sweden by Engström and Carlsson-Kanyama (2004) in food service institutions, reported that $11-13 \%$ of the amount of food served was wasted, being a total of $20 \%$ in the whole chain. This waste, authors concluded, can have very strong economic and environmental problems, such as a probably demand of arable land equivalent to $1.5 \%$ of the area under cultivation in Sweden.

Another environmental issue due to food waste is nitrogen pollution. Grizzetti et al. (2013) estimated the nitrogen loss to the environment because of food waste, as well as the virtual nitrogen associated. Their results showed that globally $9 \%$ of the total nitrogen food supply are lost.

\subsubsection{NUTRITIONAL IMPACTS OF FOOD WASTE}

Regarding nutritional impacts of food waste, Alexander et al. (2017) show that most losses of biomass and dry matter occur before harvest at a rate of about $73 \%$ of net primary production across cropland worldwide. Finally, both consumer food waste and over-consumption add final losses of energy (42\%) and protein (61\%) in world food systems.

In a study taking into account a social analysis and a whole food chain quantification (from agricultural production to final households) of food waste and losses was also developed in Switzerland (Beretta et al., 2013). The authors showed that the largest contribution to food losses occurred both in households and in processing stages, with a $20 \%$ of the 
waste share of their input, and in total $1 / 3$ of edible calories lost within the value chain. Moreover, they concluded that in total, if no edible food parts were wasted, $50 \%$ more food calories could be available for human consumption without using more agricultural land as today.

In a global scale research evaluation of food lost within all the food chain, and its consequences in terms of freshwater, cropland and fertilizer use, (Kummu et al., 2012) concluded that around $25 \%$ of kcal of total food produced are lost or wasted within the chain (614 $\mathrm{kcal} / \mathrm{cap} /$ day). This rate of food loss results in around 23\% natural resources (freshwater, cropland, and fertilizer). They also concluded that the total cropland use "wasted" (198 million hectares per year) almost equals Africa's cropland extension, so if lower losses and food waste are achieved in any region, there would be enough food for approximately one extra billion people without using more croplands. Lastly, Kummu et al. (2012) reported that 28 million tons of fertilizer use could be saved in one year. 


\section{RESEARCH CONTEXT AND OBJECTIVES}

\subsection{PROBlem STATEMENT OVERVIEW AND LITERATURE GAPS}

As shown in the State of the Art (Chapter 1), global food demand is increasing and changing rapidly because of multiple drivers including population growth, dietary shifts, and economic development. Many efforts during the last decades have only targeted the production side and supply chain, but the promotion of responsible consumption, i.e. sustainable and healthy diets, and reduced food loss and waste, is a key strategy to achieve nutritional benefits and water savings (Aleksandrowicz et al., 2016; J. A. Gephart et al., 2016; Vanham et al., 2018)

Food production under the frame of sustainable intensification, together with reducing food loss and waste and moderating animal products in diets, are nowadays key points to reduce big environmental impacts in Mediterranean countries (Galli et al., 2017). During the last two decades, many authors reported how much food consumption patterns are changing into more unhealthier and less sustainable diets in the Mediterranean region (Baldini et al., 2009; Naska et al., 2006; Serra-Majem et al., 2004), especially intensified in countries like Spain, Italy or Greece (Bach-Faig et al., 2011b; Bonaccio et al., 2012; Da Silva et al., 2009).

These dietary shifts can cause important health problems such as coronary diseases, diabetes, overweight, and obesity. This circumstance is driving national health and food agencies to raise awareness among citizens about the importance of adopting healthier food habits. Spain stands among the top ten countries in the broader Europe region in terms of both adult obesity and overweight ( $27 \%$ and $62 \%$ of the total population respectively), and the prevalence is on the rise (WHO, 2013). This is why Spain (as many other countries) is making significant efforts to reduce food loss and waste, reverse growing obesity problems, and promote the adoption of healthier food habits like the recommended, local, healthy and traditional Mediterranean Diet.

Additionally, water availability problems have been a historical standpoint in Spain, closely linked to growing water demand, particularly of agriculture, in a semi-arid climate setting (López-Gunn et al., 2012). As a result of this, Spanish policies are very much aimed at increasing efficiency in the use of water in agriculture (Garrido et al., 2010), and concepts like the water footprint (WF) or virtual water (VW) are gained traction when trying to link water resource use and food production. Lowering water footprints in this semi-arid context (where many problems regarding water management are related to 
irrigation water use), can be understood as a measure aimed to improve water' sustainability and lessening the pressure on water scarcity.

The literature gaps found in the literature review process are below described:

\section{Mediterranean traditional diet}

Yet, lack of research and data still make the comparison and assessments of the shifting away that Spanish consumers are doing from the healthy, traditional, local, and recommended the Mediterranean diet difficult. Studies like the ones of Bach-Faig et al. (2011b), Varela-Moreiras et al. (2010), and Da Silva et al. (2009) are some examples of the few works about adherence of Spanish food consumption to the Mediterranean diet. Even so, these studies also have certain limitations regarding their data and methodology, such as the use of not recent household's databases information, the disregard of the Mediterranean new pyramid guidelines or the use of wide and global data from FAO.

\section{SDG 12 in Spain}

Among the different goals and targets, SDG 12 on responsible Consumption and production attempts to ensure sustainable consumption patterns (United Nations, 2015). However, how is it implemented in Spain? As described earlier, in the last '2018 SDG Index and Dashboards' report (SDSN, 2018b), Spain was ranked in the $25^{\text {th }}$ position out of 193 countries. Despite its relatively good global position within the ranking, other neighbor countries like France, Germany, The Netherlands, UK, or the Nordic countries, are closer to meet their SDG targets. Specifically talking about SDG 12, the overall achievement' score for Spain was only $61 \%$ of full achievement, the fourth worst score within the 17 SDGs. Moreover, the report's final recommendation was to overcome considerable obstacles in SDG 12. It is also mentioned that no OECD country is on track in achieving all of the SDGs, especially because of no available data for some of the SDGs, as the $12^{\text {th }}$ one (together with the $13^{\text {th }}$, the $14^{\text {th }}$, and the $15^{\text {th }}$ ).

Within the report about SDGs' implementation in 100 Spanish cities (Sánchez de Madariaga et al., 2018), results show that SDG 12 is in the $14^{\text {th }}$ position (out of 17) of achievement's level within all cities, and only SDGs like 11, 5, and 8 (the last one), had even worse results. The big differences observed between the northern cities (with better results) and the southern ones, as well as the lack of data at the municipal level for this SDG are also mentioned, making the selected indicators focus only on municipal waste reductions and leaving the rest practically unassessed.

Finally, in the Spanish National Voluntary Report to the UN about its action plan for the 2030 agenda (Gobierno de España, 2018), SDG 12 achievements and actions are presented in relation to sustainability policies and environmental improvements, action in the educational field, improvement in the waste prevention and management, business internationalization, circular economy, and sustainable management of agro- 
ecological systems. Nevertheless, no data, information, progress, and future actions related to healthy and sustainable consumption, the shifting away from the Mediterranean Diet or the nutritional impacts of actual trends can be found.

\section{Food trends data}

As explained, many studies have shown that changes towards healthier diets may deliver water and nutritional benefits. Yet, gaps within the literature show the lack of studies about locally recommended diets and not only global food trends. Most of the studies published addressing the composition of diets and associated water savings are focused on making comparisons between different "sustainable" dietary patterns obtained from options sourced from recommendations by general public health organizations and annual international statistics, like the food balance sheets of FAO (FAO, 2001).

Some of these databases provide wide and general results and concepts, making them barely comparable with others. Little work has been done to compare real, local and/or seasonal recommended diets. Comparing recommended diets, elaborated with national and traditional recipes, dishes and products could provide insightful results about the relationship between consumption patterns and water impacts, and the ingredients that generate the largest water savings.

\section{Household's food waste and consumption}

One of the facts that the United Nations considers developing SDG 12 is that households have a high influence in several and different environmental impacts through their dietary choices and habits. So, even if many recent studies put consumer's at the focus point to reduce food waste and achieve sustainable consumption (Galli et al., 2017), few of them have compared national data at household level in order to evaluate and provide results on current and realistic national dietary patterns.

Similar limitations occurred with actual household's food waste levels data. To assess food waste, few common methodologies and definitions have been implemented, making them also barely comparable one with others. Even fewer data has been found to assess nutrient losses because of food waste at a household level (i.e., the nutritional impacts of food waste). Finally, the little comparison between recommended and "healthy" food patterns with actual household's food trends has been developed, especially under a nutritional and/or water impacts perspective.

\section{Food consumption and waste' water impacts}

Not so many studies have addressed the relationship between diets and associated water impacts. Many of the literature focuses more on GHG emissions that cause different kind of diets, rather than water impacts' assessments. This lack of research also includes studies of food loss and waste. Food waste contributes directly to excess freshwater 
consumption (Hall et al., 2009). But, on the other hand, only a few studies have focused on the food waste-freshwater savings ratio, albeit in global terms (Gustavsson et al., 2011; Kummu et al., 2012) or for individual products (Ridoutt et al., 2010).

\section{Changing diet and lessen food waste combination}

Very limited literature has analyzed the potential water savings that could occur by combining dietary changes together with reducing food waste. Only some recent studies like the one of Jalava et al. (2016) assessed the combination of halving food losses and limiting the share of animal protein in a diet to $25 \%$ of the total (concluding a net reduction of $23 \%$ in Blue WF and $28 \%$ in Green WF). Nevertheless, the data used by these authors for diets were from Food Balance Sheets from FAO (FAO, 2001), and the wide and global food loss and waste levels used by Gustavsson et al. (2011). Therefore, more research must be done of the combined potential of dietary changes with food waste reduction, in order to study possible alternatives to achieve water savings.

\section{Nutritional Water Productivity}

Only recently and few studies (Mabhaudhi et al., 2016; Wenhold et al., 2012) highlighted the need to link water use in agriculture with food and nutrition security in order to improve human health (Mabhaudhi et al., 2016), using the Nutritional Water Productivity concept (NWP) developed by Renault and Wallender (2000) in different diets.

\section{Imports and virtual water}

The Mediterranean region consumes nearly $40 \%$ more renewable natural resources and ecosystem services that the ones it provides, relying on imports to meet half of its natural resources needs (Galli et al., 2015). This links with the data provided by Lassaletta et al., (2014b), where they reported that the total imports of agricultural products have increased nine times in Spain from the 1960s to early 2010s. Very little literature can be found connecting water imports and VW of food trade analysis in Spain, regarding diets or food waste.

\subsection{THESIS MOTIVATION AND OBJECTIVES}

\subsubsection{MAIN GOAL}

Bringing back Mediterranean traditional lifestyle diets to the consumer (especially to the young and urban group), as well as knowing the water and nutritional impacts of such a consumption shift (in order to achieve a sustainable development) are main objectives to be achieved in the upcoming decades. 
Therefore, one of the main motivations of this thesis is to provide a deeper understanding of consumer behaviors and actual trends, as well as an evaluation of their nutritional, environmental and health impacts.

In addition, it aims at providing better methodological approaches to assess these impacts. Moreover, the thesis attempts to continue and develop these studies and create different databases, methodologies approaches and inform policies that could link nutrition, diets, water, environment, and health, allowing for a better understanding of the relationship between food security, environment, and agriculture.

Consequently, the main goal of the thesis is to study and evaluate the consequences of the shifting away of Spanish consumers from the traditional and recommended Mediterranean dietary pattern, looking also at households' food waste generation, and assessing the water and nutritional impacts that these practices have. The thesis's goal aims to contribute to SDG 12, promoting the transition towards more sustainable food consumption patterns (diets) and reducing food waste to a minimum.

This thesis links diet choices and food waste consequences with their water or nutritional impacts. Therefore, its general objective raises two questions:

Is actual Spanish household's food consumption shifting away from the healthy, traditional, local, and recommended Mediterranean diet?

Does a possible shifting away (or moving closer) from responsible food consumption patterns (SDG 12) as the Mediterranean Diet and a reduction of food waste, produce significant water and nutritional impacts?

\subsubsection{SPECIFIC OBJECTIVES}

To reach the main goal, the thesis attempts to bridge the gaps found in the literature, and addresses three specific objectives raised under three groups of questions:

I. Is the Mediterranean Diet a sustainable diet? What is its water consumption impacts compared to other recommended diet? Will changing product's production area have a larger impact on water footprints than changing the composition and amounts of a given diet? What are the products in the diet that require the largest volumes of water to be produced?

II. How much food do Spanish households consume and waste at home? Which is the percentage of imported water due to the food consumed and/or wasted imports? How many water and nutrients are lost due to food waste? What is the water impacts of household food consumption and food waste during one year? 
III. In view of the possible observed shifting away from the recommended Mediterranean diet in Spanish households, which nutritional and water impacts could have such diversion? Is Mediterranean Diet more healthy and sustainable? Do we obtain with the recommended diets more nutrients per liter of water used in their production?

\subsection{STRUCTURE OF THE THESIS}

This thesis is organized into five different chapters. Covering the state of the art (literature review), the research context and objectives, the methodology, the main results and discussion and, finally, the conclusions (with the limitations and future research included). Figure 2.1 gives an overview of the structure of the thesis.

Through Chapter 1: State of the Art, a comprehensive literature review of the environmental, social, and economic context of food production, trade, and food security is provided. It also reviews the main difficulties and challenges to develop sustainable agricultural growth and how the managing of food demand (i.e. responsible consumption, SDG 12) is one of the most important and feasible alternatives. Finally, it addresses the review in the literature of different options and meanings of responsible food consumption and their environmental, water and nutritional impacts.

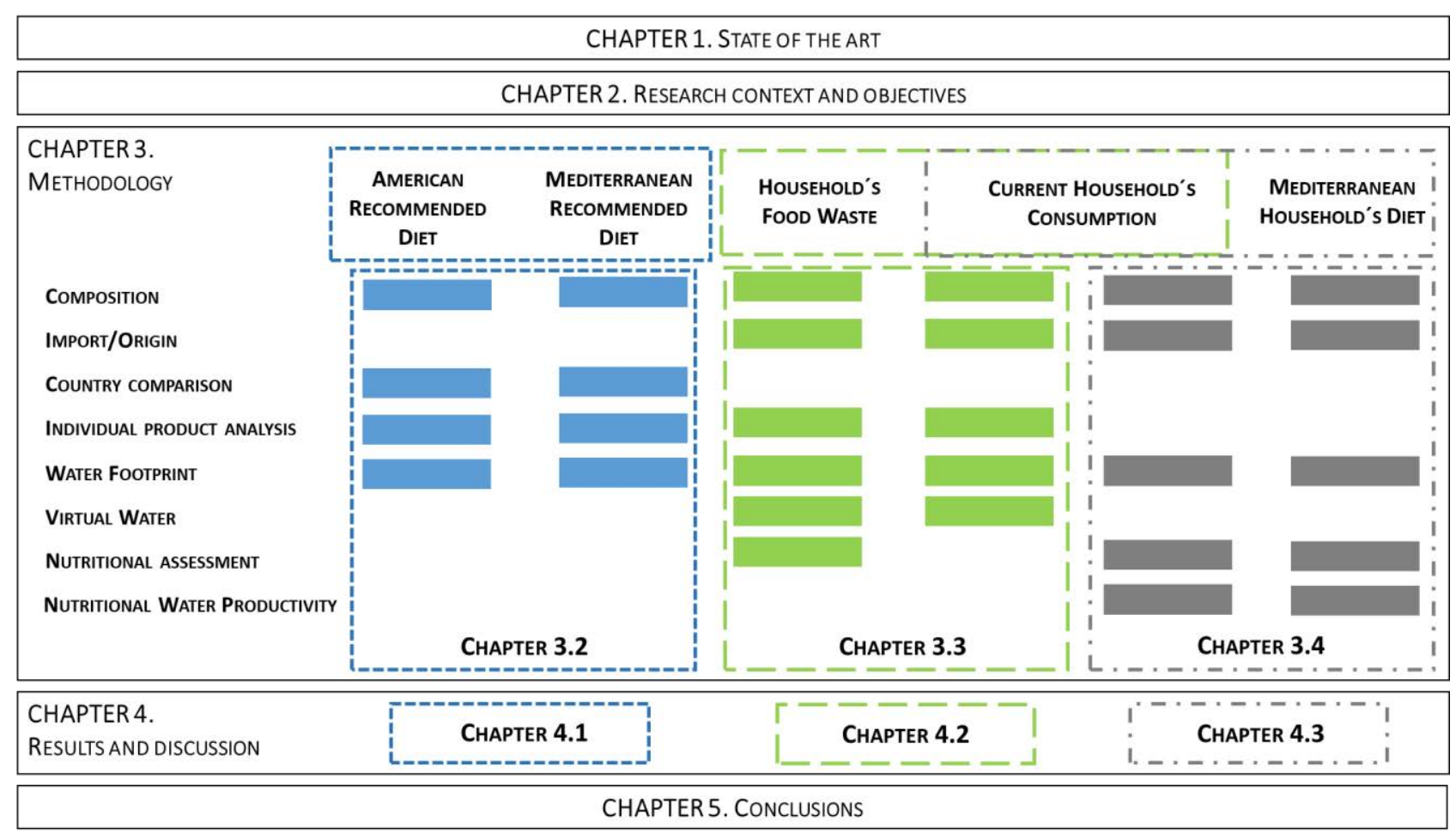

Figure 2-1. Structure of the Thesis. Source: Own elaboration 
Chapter 2: Research context and objectives, sets the thesis context, motivation, and framework, besides the general and specific objectives. Chapter 3: Methodology, and Chapter 4: Results and Discussion, contain the main original and experimental work contribution of this thesis.

Each of these chapters -divided into different sections-, address the three main research studies contained in the thesis and respond to the specific objectives raised before in Chapter 2.2, giving to the whole study an all-embracing theme. The picture of the three research studies of the thesis, and their answers to each of the specific objectives are now described in order to a better understanding:

The first research study: 'Evaluating the water footprint of the Mediterranean and American diets', tries to answer the research questions of specific objective I:

This part of the thesis assesses the sustainability of the Mediterranean Diet, (documented as a healthy and sustainable diet, and recognized by UNESCO as a cultural World Heritage), by comparing its Water Footprint with another recommended diet; the American, and to evaluate the water savings of possible dietary shifts in the two countries (Spain and United States). In addition, it attempts to deepen the understanding of the relationship between products origin and consumption patterns, and their influence on total WF and the diet's sustainability, as well as the identification of those products that need more water for being produced.

$>$ The second research study: 'Food consumption and waste in Spanish households: water implications within and beyond national borders', tries to answer the research goals of the thesis's specific objective II:

The research is extended to identify and analyze the food consumption and food waste patterns of Spanish consumers using annual household data; explore the origin of the consumed and/or waste products; evaluate nutrients loss due to food waste, and the Water Footprint of household consumption and food waste in order to evaluate water consumption and savings at a household level.

$>$ The third research study: 'A Comparison of the Mediterranean Diet and Current Food Consumption Patterns in Spain from a Nutritional and Water Perspective', tries to answer the research goals related to specific objective III:

Develop and calculate the composition, nutritional assessment, water footprint (WF), and the nutritional water productivity (NWP) (i.e. nutritional value per unit of water, that is, how many nutrients per liter of water used therein) of the current food 
consumption in Spanish households in comparison with the recommended and traditional Mediterranean diet (applied and estimated to a household level).

Finally, Chapter 5 approaches the main synthesis and conclusions of the research, and the limitations and future areas of study.

\subsection{Research conteXt and Publications}

This Ph.D. thesis is based upon research carried out from October 2015 to December 2018 at the Research Centre for the Management of Agricultural and Environmental Risks (CEIGRAM), of the Universidad Politécnica de Madrid (UPM), within the Doctoral Degree program of Agro-Environmental Technology for Sustainable Agriculture (TAPAS). All the research work was conducted within the CEIGRAM, and with the Water Observatory of the Botín Foundation.

CEIGRAM is a joint research center created in 2007 under a public-private collaboration agreement, whose activity focuses on development and innovation, dissemination and training, in the field of analysis and management of agricultural and environmental risks. The Water Observatory is an interdisciplinary "think tank" that aims to contribute to the current and emerging debates on water management in Spain and around the world and to promote and improve water policy. Two teams, one in CEIGRAM and the other one in the Faculty of Earth Sciences at the Complutense University of Madrid support it.

The thesis, as mentioned before, was initiated in October 2015. The research during the first year was primarily concerned on the literature review (Chapter 1: State of the Art) and the development of the first research study. During my second year (from December 2016 to November 2017), the analysis moved towards studying real food consumption in Spanish Households for one year, as well as the assessment of the food waste generation, to complete the second research study.

During the third year, and as a part of my training program, I spent 5.5 months in the Food and Agriculture Organization of the United Nations (FAO) as an international research Ph.D. stay. From the mid-February 2018 until the beginning of August 2018, I worked in the Land and Water Division (CBL) of FAO headquarters in Rome, Italy. The research internship was done working under its 'Water embodied in food loss and waste' and 'Water and Nutrition' ongoing projects. For the first one, I measured the impact of food loss and waste on water resources focusing on rice and maize crops in African Countries. Within the 'Water and nutrition' project, I gained knowledge by working to support the development of a methodological analysis to measure water productivity and nutritional and economic outcomes, by moving to an integrated approach of "more nutrition and better economic prospects per drop". Resulting from the mentioned stay 
and cooperation, a third research study was undertaken to compare the current consumption (already assessed in the second study), with an estimation of the Mediterranean recommended diet at a household level.

From the work done for the completion of the thesis, I wrote three research papers (two of them already published in indexed international journals and the third one under review), one-book chapter, and presented eight oral communications in national and international congresses and conferences. The list of publications, book chapter, and conference proceedings of the thesis can be seen in Table 2.1, enumerated in chronological order:

Table 2.1. List of publications, book chapters and conference proceedings of the Thesis.

\begin{tabular}{|cccc|}
\hline \multicolumn{4}{c|}{ RESEARCH STUDYI } \\
EVALUATING THE WATER FOOTPRINT OF THE MEDITERRANEAN AND AMERICAN DIETS \\
\hline \hline \multicolumn{4}{c|}{ CHAPTER OF THE THESIS } \\
INTRODUCTION & METHODOLOGY & RESULTS AND DISCUSSION & CONCLUSIONS \\
1 (PART) & 3.2 & 4.1 & 5 (PART) \\
\hline
\end{tabular}

PUBLISHED PUBLICATIONS

Blas, A., Garrido, A., \& Willaarts, B. A. (2016). Evaluating the water footprint of the Mediterranean and American diets. Water, 8(10), 448. Reference: (Blas et al., 2016).

\section{BOOK CHAPTERS}

Blas Morente, A. (2017). Huella hídrica y huella virtual: definiciones, aplicaciones y estudios aplicados al sector agroalimentario. In: Hacia un agua justa (pp. 311-317). Ediciones Universidad de Valladolid.

\section{CONFERENCE PROCEEDINGS}

Blas, A. (2015). Política y Economía del Agua: colores del agua, mercado del agua, huellas hídricas. Oral presentation at the Course: "Hacia un agua justa para hombres, ríos, ciudades y pueblos". Valladolid University, 12 December 2015, Palencia (Spain).

Blas, A. (2016). Comparison of water footprints of Mediterranean and American diets. Oral presentation at the International final EURO-AGRIWAT Conference: "Water footprint of agricultural products: progress, challenges and solutions". EURO-AGRIWAT, 7-9 March 2016, Wageningen (The Netherlands).

\begin{tabular}{cccc}
\hline \hline \multicolumn{4}{c}{ RESEARCH STUDY II } \\
FOOD CONSUMPTION AND WASTE IN SPANISH HOUSEHOLDS: WATER IMPLICATIONS WITHIN AND BEYOND \\
NATIONAL BORDERS \\
\hline \hline \multicolumn{4}{c}{ CHAPTER OF THE THESIS } \\
INTRODUCTION & METHODOLOGY & RESULTS AND DISCUSSION & CONCLUSIONS \\
1 (PART) & 3.3 & 4.2 & 5 (PART) \\
\hline
\end{tabular}

\section{PUBLISHED PUBLICATIONS}

Blas, A., Garrido, A., \& Willaarts, B. (2018). Food consumption and waste in Spanish households: Water implications within and beyond national borders. Ecological Indicators, 89, 290-300. Reference: (Blas et al., 2018). 


\section{CONFERENCE PROCEEDINGS}

Blas, A. (2017). Environmental impacts of food patterns in Spanish households. Oral presentation at the Course: "Il Jornadas de investigación agraria para el desarrollo: 'Hambre 0 y alimentación sostenible: el papel de la investigación agraria para el desarrollo'. Universidad Politécnica of Madrid. 22-23 March 2017, Madrid (Spain).

Blas, A. (2017). Huella hídrica: indicador de eficiencia y sostenibilidad para una mejor gestión del agua. Oral presentation at the conference held by (IAHR), Spain Water and EsAgua, 13 June 2017, Ministerio de Agricultura y Pesca, Alimentación y Medio Ambiente, Madrid (Spain).

Blas, A. (2017). Food waste and consumption in Spanish households: water implications and origin analysis. Oral presentation at the National Congress: "XI Congreso de la Asociación Española de Economía Agraria: sistemas alimentarios y cambio global desde el Mediterráneo". Asociación Española de Economía Agraria (AEEA), 13-15 September 2017, Elche and Orihuela (Spain).

Blas, A. (2017). Estudios sobre usos y consumos de agua (huella hídrica) de productos alimentarios. Consumo y desperdicio de alimentos en el hogar. Oral presentation at the Conference: "Indicadores de impactos ambientales de los productos de consumo alimentario ". Fundación Botín, 12 December 2017, Madrid (Spain).

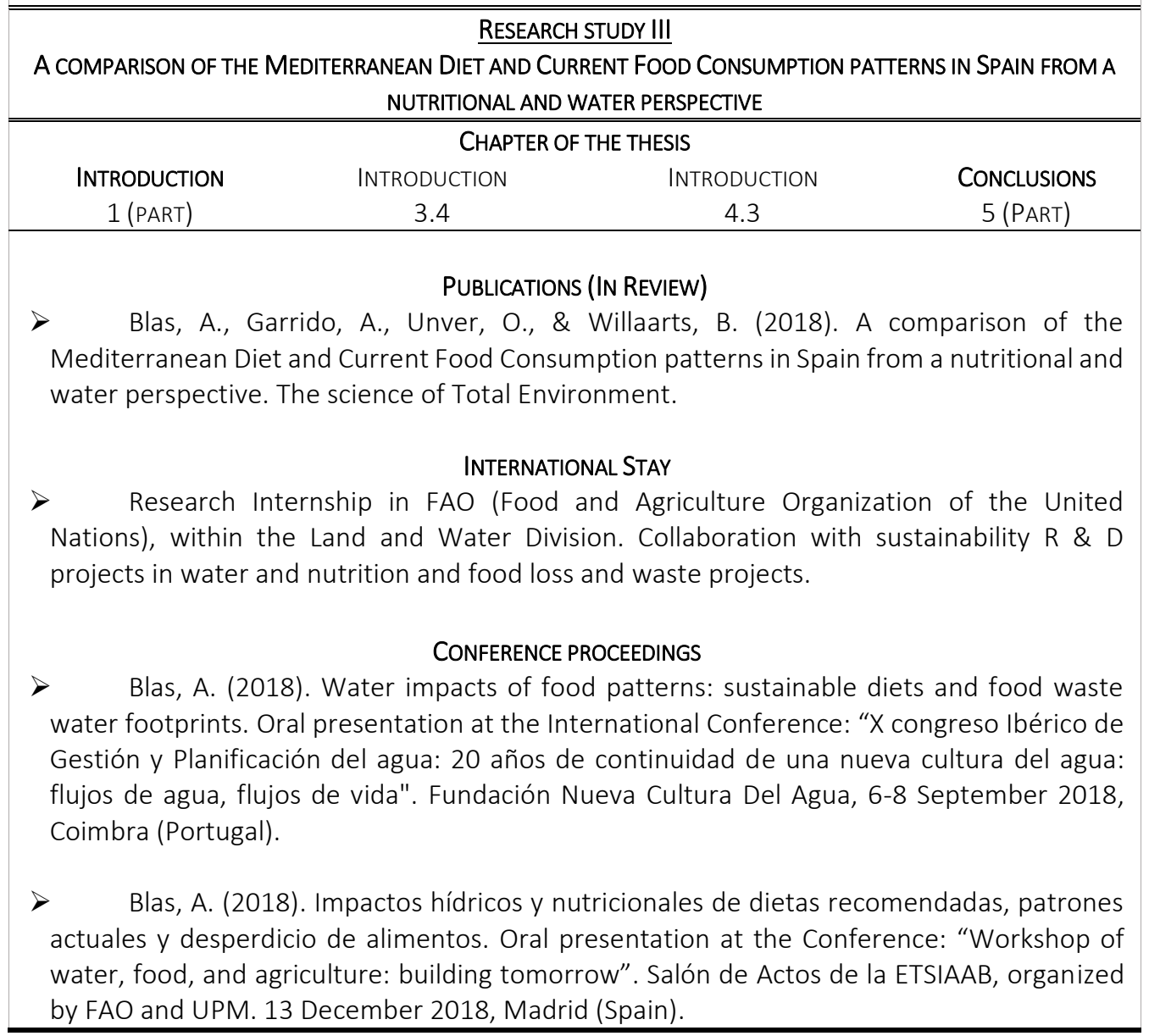




\section{METHODOLOGY}

\subsection{OVERVIEW AND DEFINITIONS}

Throughout all the research strands of the Thesis, the same methodological approach is used. This approach particularly relies on the analysis of different databases of food waste and recommended and current diet's composition, with a trade analysis of imports, all under a Water Footprint Assessment (WFA) and nutritional analysis. The methodological approach overview and definitions are described below.

\subsubsection{WATER FOOTPRINT ASSESSMENT AND LIFE CyCLE ANALYSIS}

In the course of the last decades, several methodologies, including the WFA (Hoekstra et al., 2011), and the life cycle analysis (LCA) (Boulay et al., 2013, 2018; Pfister et al., 2017), have been developed to assess the impacts on water resources linked to food production and consumption patterns. Both approaches involve several-steps and the suitability of one over the other very much depends on the research goal.

The WFA is a suitable approach particularly when the overall purpose of the assessment is to identify options for water savings, reallocation and better management, and also in order to raise awareness about water issues (Boulay et al., 2013). The WFA was developed by Hoekstra et al. (2011) and is a water accounting methodology consisting in a four-step approach: (1) definition of the scope and goals of the assessment; (2) water accounting; (3) sustainability assessment; and (4) response formulation. There is ample literature exemplifying the usefulness of WFAs (Chico et al., 2013, 2010; De Miguel et al., 2015; Dumont et al., 2013; Hoekstra et al., 2011; Salmoral et al., 2011; Vanham et al., 2018).

As opposed to the WFA, the LCA is more suitable when the goal is to evaluate the environmental impacts linked to different human activities, where water use is one among many different impacts that can be assessed (Boulay et al., 2013). LCA also involves four steps: (1) definition of the goal and scope; (2) inventory; (3) impact assessment and (4) interpretation. The LCA methodology and the associated ISO 14046 (ISO (International Organization for Standardization), 2013), has been used during last years for some environmental sustainability programs.

Both the WFA and the LCA rely on the use of quantitative indicators (e.g., the water footprint), although in different phases of the assessment (Boulay et al., 2013). While LCA methodology focus on products' sustainability and its impacts (product-focus), WFA focuses on analyzing the sustainability, efficiency, equitable allocation and use of 
freshwater in both local and global context (i.e., a water management focus) (Boulay et al., 2013). Several authors have compared both methodologies (Berger and Finkbeiner, 2010; Boulay et al., 2013), and applied them to different food products, such as tomato sauce (Manzardo et al., 2016), tea and margarine (Jefferies et al., 2012), biomass production from energy crops (Pacetti et al., 2015), or broccoli (Milà et al., 2010) to assess the advantages and disadvantages of each one.

Lowering water footprints in a semi-arid context like the Spanish (where many problems regarding water management are related to irrigation water use), can be understood as a measure aimed to improve water' sustainability and lessening the pressure on water scarcity. As a result of this, Spanish policies are very much aimed at increasing efficiency in the use of water in agriculture (Garrido et al., 2010), and concepts like the water footprint (WF) or virtual water (VW) are gained traction when trying to link water resource use and food production.

Besides, Vanham et al. (2018) reported that the WF is an effective and valuable communication tool and a global methodological concept for raising consumer awareness about the water resources required to produce the food that we consume. They also reported how widely it is used in statements by different organizations, including recent official studies published by the European Commission (Gawlik et al., 2017). Therefore, there is plenty of literature illustrating the usefulness of WF (Hoekstra, 2016; Vanham et al., 2018), as well as its blue, green, and grey components (Hoekstra, 2016).

Yet, most of the studies published so far on diets, water impacts relied on the methodology proposed by the WFA, and less work has been published yet applying an LCA approach. Therefore, WFA approach is issued in the present study, and particularly we focused on phase two (i.e., water accounting), to assess the water embedded in each menu, recommended or current diet and household's food waste.

\subsubsection{WATER FOOTPRINT AND VIRTUAL WATER}

Concepts like the water footprint (WF) or virtual water (VW) are useful for linking water resource use to food production:

\section{Water Footprint}

The WF of a product (in this Thesis, a food product) is understood as the direct and indirect appropriation of freshwater resources required to produce the good, this being the final result the sum of three components: green, blue and grey (Mekonnen and Hoekstra, 2011).

- Green WF: refers to the rainwater stored in the soils and directly evapotranspired by crop products. 
- Blue WF: refers to the volume of surface and groundwater embedded in the production of a good. In agriculture, the blue WF refers to the total volume of irrigated water that is evapotranspired by a crop and embedded in the production of livestock products.

- Grey WF: is an indicator of water quality degradation, and refers to the volume of freshwater required to assimilate the load of pollutants generated along the production chain of a product, in order to reach the quality standards established in the environmental regulations.

- Total WF: the total WF of a product is the sum of all the water consumed along its different production steps.

Consumptive use of water (or Consumptive WF), is estimated and considered among this Thesis as the sum of Green and Blue WFs. The Green WF was included as a consumptive use of water because its management in relation with crops also affects the use of irrigation water and, therefore, can be understood as a potential saving of blue WF (even if it is an indirect impact). Moreover, about using Green WF as a consumptive water use together with Blue WF, we are following the idea that "Green water shortage in agriculture is, in fact, the reason for agriculture's blue water demand and therefore the driver of blue water scarcity" (Hoekstra, 2016, p. 567). Moreover, in this paper, the author argues (same page); "Green water resources are not scarce. It is very common that farmers structurally suffer from a shortage of rain. Green water resources are often not perceived as scarce, because rain comes for free, but actually, they are".

Finally, Hoekstra reported (Hoekstra, 2016, p. 567): "There are alternative competing uses for green water (e.g. production of food crops, feed for animals, energy crops, fibre crops or trees for timber and paper) and there is a conflict between appropriating green water resources for the economy versus leaving them for natural vegetation. Competing demands for a limited resource defines the resource as scarce" and "The world's largest consumer of blue water, i.e. irrigated agriculture, uses a lot of green water as well. Green and blue water scarcity and depletion in a catchment are strongly connected. The reason why crops are irrigated is that the rain is insufficient to give a good crop yield".

Nonetheless, although a consumptive use of water, green WF is, as opposed to blue water, also a land-related concept.

\section{Virtual Water}

Virtual Water is the water used in the production of an internationally traded agricultural good. Therefore, it is a concept that links trade, food, and water (Allan, 2003). Water imported or exported to a given geographical region (e.g., a country) is the volume of VW 
associated with the trade of a particular product, that is, the volume of water used to produce a particular product, measured at the place where it was actually produced.

International food trade is, therefore, a mean of transferring water resources (the water needed to produce the agricultural or livestock product) between regions (Dalin et al., 2012). The joint analysis of WF and VW of food consumption habits permits identifying the impacts both on domestic and non-domestic water resources, detailing the products' water consumption and WF components, and what proportion can be also wasted.

\subsubsection{FOOD WASTE AND CONSUMPTION}

\section{Food waste}

The Spanish government has implemented the so-called "More Food, Less Waste" Program over the last few years in a significant effort to quantify all food waste in households, industry, and farm levels (Ministerio de Agricultura Alimentación y Medio Ambiente, 2015). To develop this strategy, the Spanish Ministry of Food and Agriculture used the food waste concept established by the European Parliament (European Parliament, 2012, p. 5) in its "Resolution on how to avoid food wastage: strategies for a more efficient food chain in the EU":

"All the foodstuffs discarded from the food supply chain for economic or aesthetic reasons or owing to the nearness of the 'use by' date, but which are still perfectly edible and fit for human consumption and, in the absence of any alternative use, are ultimately eliminated and disposed of, generating negative externalities from an environmental point of view, economic costs and a loss of revenue for businesses"

Moreover, this Strategy does not asses unavoidable waste (those foods and beverages that are not edible under normal circumstances like bones, eggshells, the skins and viscera of certain products, fish bones...) as food waste.

\section{Food consumption}

Throughout all the research strands of the Thesis, our results (and definition) assess the total food consumption as total household food shopping. That is, the total food items that final consumer is buying to eat them at homes. Therefore, it can be considered at "gross food consumption", and not as "net food consumption" or real "food intake". In order to assess the real food intake values, food waste values have to be subtracted from the purchased ones.

Its statistics were taken from surveys from the Consumption, Commercialization and Food Distribution: Household Consumption Database Program (Ministerio de Agricultura Alimentación y Medio Ambiente, 2016a). The goal of this survey is to study food consumption by households. More information about this database can be found below in section 3.3.1. 


\subsection{EVAluation of the WATER FOOtPRINT OF the MediterRaneAN AND AMERICAN DIETS}

\subsubsection{Menus ANd Diets Configuration}

To characterize the composition and product quantities of the Mediterranean diet, two seasonal weeklong menus were defined (i.e., winter and summer) using the food guidelines elaborated by the Mediterranean Diet Foundation (Fundación Dieta Mediterránea, 2015).

Each week menu included four daily meals: breakfast, morning snack, lunch and dinner. Dishes and product composition of each meal, as well as recommended daily intake quantities of each product, were defined using traditional Mediterranean recipes.

The winter menu (Menu 1) was configured with winter seasonal products, whereas the summer menu (Menu 2) in the Mediterranean diet was configured with seasonal summer products. In total, over 116 products have been included in the elaboration of the two menus.

The American recommended diet (USDAr) was configured following the guidelines of the Center for Nutrition Policy and Promotion (CNPP) of the US Department of Agriculture (USDA, 2015) and the study by Haven et al. (Haven et al., 2015). As with the Mediterranean diet, two weeklong menus (Menu 1 and Menu 2) were configured, each one containing four daily meals (breakfast, morning snack, lunch and dinner).

No differences between menus in terms of seasonal products could be made with the USDAr. Recipes, product composition and weights for the two American menus were also defined using traditional recipes from the US. Overall, 103 products were included in the elaboration of the USDAr diet.

All the recipes, dishes and products of both menus of the two recommended diets are fully described in Annex IV: Weekly recommended Menus of Mediterranean and American Diets.

\subsubsection{WATER FoOtPRint CALCULATION}

\section{Recommended Diets}

As, previously said, WFA approach is issued in the present study, and particularly this research study focused on phase two (i.e., water accounting), to assess the water embedded in each menu and diet. Specifically, we calculated the WF per person per day of the Mediterranean and USDAr diets as defined in the Global Water Footprint Standard (Hoekstra et al., 2011). 
When calculating the WF of a diet, we have only considered the amount of water consumed in the production of each food item, without considering additional water requirements for cooking purposes (e.g., boiling, washing, etc.).

This assumption was made due to the lack of detailed data regarding the amount of household water used for cooking and the fact that the largest fraction of the WF of food products lies at the field level, i.e., agricultural production (Chico et al., 2010).

To estimate the WF of the different weeklong menus we relied on the global WF database of crops (Mekonnen and Hoekstra, 2011), and livestock products (Mekonnen and Hoekstra, 2012). Both databases provide average values of green, blue and grey WF of each product (in $\mathrm{m}^{3} / \mathrm{t}$ or $\mathrm{L} / \mathrm{kg}$ ) for the time series $1996-2005$.

For this first research study, we considered that all products were produced nationally, using national values to estimate the WF of the different menus. Thus, we estimated the WF of the Mediterranean diet assuming that all products consumed are produced in Spain, whereas for the USDAr we assumed that all products have been produced in the US. Products like coffee, cocoa, pineapple, pepper, cinnamon and mustard are not produced in either of the two countries and therefore they need to be imported.

The WF of each imported product was calculated at the weighted average of the WF this product has in the main producer countries from which Spain and the US import them. The weighting factor is calculated based on the ratio of imports by the origin of the product in each of the two countries (i.e., Spain and the US).

For instance, the WF of coffee consumed in Spain was estimated as a weighted average of the WF coffee has in the major production centers from which Spain imports this product (i.e., Vietnam (40\%), Brazil (50\%) and Colombia (10\%)).

To define the origin of each imported product we used trade matrix from FAOSTAT (FAO, 2015), for the time series 1993-2013.

For each imported product in Spain, we used the following countries' WF data:

$>$ Coffee, data from Vietnam (40\%), Brazil (50\%) and Colombia (10\%); Cocoa, data from Ivory Coast (50\%), Ghana (30\%) and Indonesia (20\%); Pineapple, data from Costa Rica (100\%); Pepper, data from Vietnam (60\%), Indonesia (30\%) and India (20\%); Cinnamon, data from Indonesia (50\%) and China (50\%); and Mustard, data from Canada (100\%).

Regarding products imported into the US, we used the following countries' WF data:

$>$ Pepper, cinnamon and cocoa as in Spain (same WF values); vanilla, data from Indonesia (60\%) and Madagascar (40\%); cilantro/parsley/sesame, data from the UK (50\%) and Russia (50\%); clove, data from Indonesia (100\%); and nutmeg, data from Guatemala (50\%) and Indonesia (50\%). 
Lastly, saltwater fish and seafood (i.e., hake, tuna, sea bass, megrim, squid, mussels, cod, octopus, salmon, trout, shrimps and sardines) were assigned a WF equivalent to zero, since this study only evaluates the WF of raw products and does not include the water requirements for cooking.

Other studies have calculated the fish WF but most of them refer to aquaculture production (Pahlow et al., 2015).

Hence, the daily WF of a menu $k$ (WFmenu, in liters per capita day) was calculated as:

$$
W F_{\text {menu }}=\sum_{j=1}^{n}\left(\text { Green } W F_{j}+\text { Blue } W F_{j}+\text { Grey } W F_{j}\right) \times W{ }_{j} / 7
$$

[Equation 3.2.1]

Where $\left(\right.$ Green $W F_{j}+$ Blue $W F_{j}+$ Grey $W F_{j}$ ) is the total WF of a product $j$ (in liters $/ \mathrm{kg}$ ) and $W_{j}$ is the average intake per person and week (in kg per person).

Accordingly, the average WF of a diet i (WF diet, in liters per capita day) was estimated as:

$$
W F_{\text {diet } i}=\sum_{k=1}^{2}\left(W F_{\text {menu k }}\right) / 2
$$

[Equation 3.2.2]

To discern the relative weight that the different products have in the $W F_{\text {diet }}$ (the 116 products identified in the Mediterranean menus and the 103 of the two American menus), we grouped them into 11 different food groups:

$>$ (1) meat, fish and animal fats

(2) dairy products

(3) oil and vegetable fats

$>$ (4) legumes and nuts

$>$ (5) cereals and potatoes

$>$ (6) eggs

(7) vegetables

(8) sugar

(9) cocoa, chocolate and vanilla

$>$ (10) fruits

> (11) drink and others. 


\section{Impacts of Shifting Diets}

To assess the water impacts of changing diets we also estimated the WFdiet associated to a potential shift in the diets in the two countries-i.e., Spain adopting an American diet and the US adopting a Mediterranean diet. We assumed that all consumed products are also produced nationally, except for those products that are not produced in either of the two countries and need to be imported.

Again, we relied on the WF databases of agricultural (Mekonnen and Hoekstra, 2011) and livestock products (Mekonnen and Hoekstra, 2012) to estimate the WF $F_{\text {diet. }}$ 


\subsection{AsSESSING THE FOOD CONSUMPTION AND WASTE IN SPANISH HOUSEHOLDS, AND THEIR WATER IMPLICATIONS WITHIN AND BEYOND NATIONAL BORDERS}

Data has been collected using five main databases, which refer to food waste and consumption statistics, food import trade matrix, water footprint data for crops and animal products and Spanish national crop and food production. Table 3.1 summarizes and describes all the data sources used.

Table 3.1. Data description and sources used for the assessing the food consumption and waste in Spanish households, and their water implications within and beyond national borders

\begin{tabular}{|c|c|c|}
\hline Data type & Description & Source \\
\hline Food waste & $\begin{array}{l}\text { Household survey data on food waste } \\
\text { (t/person/year). Time period: Oct. } \\
\text { 2014-Sept. } 2015\end{array}$ & $\begin{array}{l}\text { Spanish Ministry of Agriculture, Food and } \\
\text { Environment (Ministerio de Agricultura } \\
\text { Alimentación y Medio Ambiente, 2015) }\end{array}$ \\
\hline Food consumption & \begin{tabular}{lll} 
Household surveys on food & \multicolumn{1}{c}{ consumption (t/person/year). } & Time \\
consum & \\
period: Oct. 2014-Sept. 2015 &
\end{tabular} & $\begin{array}{l}\text { Spanish Ministry of Agriculture, Food and } \\
\text { Environment (Ministerio de Agricultura } \\
\text { Alimentación y Medio Ambiente, 2016a) }\end{array}$ \\
\hline $\begin{array}{l}\text { Food imports and } \\
\text { origin }\end{array}$ & $\begin{array}{l}\text { Database of food product import and } \\
\text { exports (Oct. 2014-Sept. 2015) }\end{array}$ & $\begin{array}{l}\text { Ministry of Economy and Competitiveness } \\
\text { (Ministerio de Economía, 2016) }\end{array}$ \\
\hline $\begin{array}{l}\text { Crop and livestock } \\
\text { farming Water } \\
\text { Footprint }\end{array}$ & $\begin{array}{l}\text { Values for green, blue and grey WF in } \\
\mathrm{m}^{3} / \text { ton of all agricultural and } \\
\text { livestock products (average time } \\
\text { series 1996-2005) }\end{array}$ & $\begin{array}{l}\text { (Mekonnen and Hoekstra, 2011) } \\
\text { (Mekonnen and Hoekstra, 2012) }\end{array}$ \\
\hline $\begin{array}{l}\text { National food } \\
\text { production }\end{array}$ & $\begin{array}{l}\text { National production of every food } \\
\text { product over a one-year period }\end{array}$ & $\begin{array}{l}\text { (Asemac, 2016; ASOZUMOS, 2016; FAO, } \\
\text { 2015; INE, 2016; Ministerio de Agricultura } \\
\text { Alimentación y Medio Ambiente, 2016b, } \\
\text { 2016c; WPTC, 2016) }\end{array}$ \\
\hline
\end{tabular}

\subsubsection{FOOD WASTE AND CONSUMPTION}

As shown before, the Spanish government has implemented the so-called "More Food, Less Waste" Program over the last few years in a significant effort to quantify all food waste in households, industry, and farm levels (Ministerio de Agricultura Alimentación y Medio Ambiente, 2015). The study was launched in late 2014, and had collected bi-yearly data for the following time series at the time of the analysis: autumn 2014-winter 2015, spring-summer 2015, and autumn 2015-winter 2016. Only data for the first two semesters (October 2014 through September 2015) were considered for the purposes of 
this study, in order to have a complete one-year dataset, as the assessment was discontinued in October 2015.

This database on food waste contains information on both raw and cooked food waste per household ( $\mathrm{kg} /$ household and year) and was gathered from a sample of 4,000 households of varying sizes and income per capita, distributed randomly across different parts of Spain. For 2,000 households, information was collected by scanning each purchase made on a daily basis. Then households completed online questionnaires reporting how much and which type of products they had thrown away because of food degradation and/or spoilage over the previous week in order to quantify of food waste.

The other 2,000 households completed online weekly questionnaires (for the 52 weeks of the year) about all food products consumed at home or prepared for take-away by all members of the household (identifying sex, age and preparation method). Then they completed online questionnaires reporting the amount of food thrown away in order to quantify food waste.

The information of the sub-samples was collected and added together, and the average waste per capita was calculated assuming an average of 2.51 members per household and a total of 17.5 million Spanish households (Ministerio de Agricultura Alimentación y Medio Ambiente, 2015).

Data on food consumption per household were also collected for the period October 2014 to September 2015. Food consumption statistics were taken from the Consumption, Commercialization and Food Distribution: Household Consumption Database Program (Ministerio de Agricultura Alimentación y Medio Ambiente, 2016a). The goal of this survey is to study food consumption by households, restaurants and catering services in Spain based on consumer surveys.

A sample of 8,000 households (of different sizes and income per capita, distributed randomly across different parts of Spain) with an average household size of 2.69 members was surveyed. The data collection was based on daily note taking on household food shopping, with a monthly sampling rate.

The variables were collected by an optical barcode reader, which gave information about the product and amount purchased, the unit price and the type of establishment in which it was purchased. Information on final 199 consumed and/or wasted products were collected by the authors from the two surveys.

For ease of assessment, these food products were grouped into 10 different food groups:

(1) Meat, fish and animal fats

(2) Dairy products

(3) Oil and vegetable fats

(4) Legumes and nuts

(5) Cereals and potatoes 
$>$ (6) Eggs

$>$ (7) Vegetables

$>$ (8) Sugar and sweets

$>$ (9) Fruits

$>$ (10) Drinks, sauces and others.

Products categorized as "others" are products that do not come under any of the above labels, like assorted prepared food, salt, or honey.

\subsubsection{FOOD WASTE NUTRITIONAL ANALYSIS}

The nutritional analysis of food waste was conducted using data from the Spanish Agriculture Ministry and Spanish Nutrition Foundation databases (FEN, 2018). Data for eight nutritional components were used for all food products within the diet (estimating the ones without information with those ones of similar products).

The eight nutritional values analyzed were: Energy (Kcal), Proteins (g), Fats (g), Carbohydrates (g), Fiber (g), Water (g), Minerals (mg) and Vitamins (mg). Data of nutritional values were given per 100 grams of product. Total lipids (fats) were the sum of saturated, monounsaturated and polyunsaturated Fatty Acids, v-3, C18: 2 Linoleic (v6) and Cholesterol. Minerals were the sum of Calcium, Iron, lodine, Magnesium, Zinc, Sodium, Potassium, Phosphorus and Selenium. Finally, Vitamins were the sum of: Thiamine, Riboflavin, Niacin equivalent, Vitamin B6, Folates, Vitamin B12, Vitamin C, Vitamin A (Retinol), Vitamin D and Vitamin E.

The multidimensional food waste nutritional analysis performed multiplying each product's nutritional value ( $\mathrm{Np}$ ) with its waste value: $\mathrm{Fw}_{\mathrm{p}}$, that is the total annual food waste of a product $\mathrm{p}$ on a household basis in $\mathrm{kg} / \mathrm{capita}$ year $(\mathrm{kg} / \mathrm{cy})$. The sum of all the 199 products makes the food waste nutritional value. The results were also grouped within the food groups explained before.

\subsubsection{IMPORTED WATER AND ORIGIN OF FOOD PRODUCTS}

To estimate the volume of imported water resources embedded in Spanish household food consumption and waste i.e. VW, we relied on the global WF database of crops (Mekonnen and Hoekstra, 2011), and livestock products (Mekonnen and Hoekstra, 2012). As mentioned before, both databases provide average worldwide values for the green, blue and grey WF of all products ( $\mathrm{m}^{3} / \mathrm{t}$ or $\mathrm{l} / \mathrm{kg}$ ) for the time series $1996-2005$.

To discern the VW volume, we analyzed the food products trade matrix (exports and imports) of the most consumed products in terms of kilograms of annual consumption (and waste). In particular, we analyzed the origin of a total of 84 out of 199 products, which accounted for $70 \%$ of the final household consumption (and waste). To determine 
the origin of these 84 most consumed food products, we used trade information from the Datacomex platform; multidimensional databases of Spanish foreign trade with specification of countries and groups, classification of flow (export-import), territory (provinces, autonomous communities), conditions of delivery, periodicity and other variables such as monetary value or weight (Ministerio de Economía, 2016).

The annual trade data (aggregate monthly data from 1 October 2014 to 30 September 2015) specifies tons of product imported to Spain per year and country. Grouping the products per country of origin, allowed to estimate the imported VW from a country c to Spain as:

$$
\text { IVWc }=\sum_{p=1}^{n}\left[Y_{p, c} \cdot\left(\text { Green WF } F_{p, c}+\text { Blue WF } F_{p, c}+\text { Grey WF } F_{p, c}\right)\right] \cdot H_{i}
$$

[Equation 3.3.1]

where $I V W_{c}$ is the imported virtual water from a country $c\left(m^{3} /\right.$ year); $Y_{p, c}$ is the total amount of a product $p$ imported to Spain from a country c (ton/year); Green WFp, Blue $W F_{p, c}$, Grey $W F_{p, c}$, are the green, blue, and grey $W F s$ per product and country of origin ( $\mathrm{m}^{3} /$ ton). $\mathrm{H}_{\mathrm{i}}$ is the household consumption factor i.e. the proportion of food that is consumed domestically, and excluding the food consumed at restaurants, bars, and work places. For this analysis, $H_{i}$ was estimated at 0.75 , based on the data collected by the Spanish Ministry of Agriculture (Ministerio de Agricultura Alimentación y Medio Ambiente, 2016a). The data were actually sourced from Spanish historical series data for the period from 1987 to 2006 on consumption and expenditure trends by sectors: households, hotels and restaurants and institutions. So, regarding this database, the mean final household food consumption for this analysis was estimated at 0.75 (75\%). This means that household's food consumption only accounted for the $75 \%$ of a daily food intake, and the rest of the food consumption is outside homes; bars, restaurants, work places, institutions, etc. Accordingly, the total amount of imported VW of Spanish household food consumption (IVW total, measured in $\mathrm{m}^{3}$ per year) was estimated as:

$$
\mathrm{IVW}_{\text {total }}=\sum_{\mathrm{c}=1}^{\mathrm{n}} \mathrm{IVWc}
$$

[Equation 3.3.2]

We used the same approach specified in Equation 3.3.1 to estimate the origin of VW associated with food waste in Spanish households as follows: 


$$
I V W_{\text {waste } c}=\sum_{p=1}^{n}\left[Y_{p, c} \cdot\left(\text { Green WF } F_{p, c}+\text { Blue WF } F_{p, c}+\text { Grey WF } F_{p, c}\right)\right] \cdot H_{i} \cdot\left(F W_{p} \cdot 100 / F c_{p}\right)
$$

[Equation 3.3.3]

where IVW waste $_{\text {c is }}$ the VW for the food waste from a country c $\left(\mathrm{m}^{3} /\right.$ year); FW $\mathrm{w}_{\mathrm{p}}$ is the total food waste of a product $\mathrm{p}$ on a household basis (kg/cy) in Spain, and F $\mathrm{c}_{\mathrm{p}}$ is the total food consumption of a product $\mathrm{p}$ on a household basis $(\mathrm{kg} / \mathrm{cy})$ in Spain.

Accordingly, the total imported VW of Spanish household food waste (IVW waste total, measured in $\mathrm{m}^{3}$ per year) was estimated as:

$$
\mathrm{IVW}_{\text {waste total }}=\sum_{\mathrm{c}=1}^{\mathrm{n}} \mathrm{IVW} \text { waste c }
$$

[Equation 3.3.4]

\subsubsection{WATER FOOTPRINT OF FOOD CONSUMPTION AND WASTE}

We estimated the WF of food consumption and food waste for Spanish households using as a reference period from 1 October 2014 to 30 September 2015. We took into account the proportion of food consumed and wasted that is nationally produced and imported. Table 3.1 reports the national data sources used. Assuming that all the imported products were consumed in the diet (and the rest were produced nationally), we calculated a factor of net imports over net imports plus national production in order to calculate the percentage of imports over national production as follows:

$$
X_{P}=\left(\frac{I_{p}}{I_{p}+P_{p}}\right) \cdot 100
$$

[Equation 3.3.5]

Where $X_{p}$ is the import factor of a product $p$ in $(\%), I_{p}$ is the total amount of a product $p$ imported to Spain in a year from all countries, and $P_{p}$ is the total Spanish national production of a product $\mathrm{p}$ in a year. To estimate the imported WF of the each of the 84 most consumed products $\left(I W F_{p}\right)$, we used the specific national data on WF contents (corresponding to each country of origin) and food product origin shown in Table 3.1. For those products whose imports are concentrated in a few countries (i.e. products where $90 \%$ of the total imports is concentrated in five countries), the $I W F_{p}$ measured in $\mathrm{m}^{3}$ per ton was calculated as: 


$$
I W F_{p}=\sum_{c=1}^{5}\left[\left(\text { Green WF }{ }_{p, c}+\text { Blue WF } F_{p, c}+\text { Grey WF } F_{p, c}\right)\right] \cdot\left(Y_{p, c} \cdot 100 / I_{p}\right)
$$

[Equation 3.3.6]

Where, as defined in Equation 3.3.1, $Y_{p, c}$ is the total amount of a product $\mathrm{p}$ imported to Spain from a country $c$ (ton/year) and Green $W F_{p, c}$, Blue $W F_{p, c}$, Grey $W F_{p, c}$, are the green, blue, and grey WFs per product and country of origin ( $\mathrm{m}^{3} /$ ton). On the other hand, for products whose imports are less concentrated (i.e. products where $90 \%$ of imports is spread across more than five countries) the $I W F_{p}$ measured in $\mathrm{m}^{3}$ per ton was calculated as:

$$
\begin{aligned}
& I W F_{p}=\left[\sum_{c=1}^{5}\left[\left(\text { Green WF } F_{p, c}+\text { Blue WF } F_{p, c}+\text { Grey WF } p, c\right)\right] \cdot\left(Y_{p, c} \cdot 100 / I_{p}\right)\right]+ \\
& {\left[\left[\left(\text { Green } W F_{i}+\text { Blue } W F_{i}+\text { Grey } W F_{i}\right)\right] \cdot\left(Y_{r} \cdot 100 / /_{p}\right)\right]}
\end{aligned}
$$

[Equation 3.3.7]

Where $\left(\right.$ Green $W F_{i}+$ Blue $W F_{i}+$ Grey $\left.W F_{i}\right)$ are the international average WF values for a product $p ; Y_{r}$ is the remainder of the total amount of a product $p$ (tons). Finally, the WFs for food consumption ( $\left.W F_{\text {con }}\right)$ and food waste $\left(W F_{\text {wasted }}\right)$ measured in $\mathrm{m}^{3}$ per capita year $\left(\mathrm{m}^{3} / \mathrm{cy}\right)$ were calculated using Equations 3.3.8 and 3.3.9, respectively:

$$
W F_{C o n}=\sum_{p=1}^{199}\left[\left(I W F_{P} \cdot X_{P}\right)+\left(W F_{P} \cdot\left(100-X_{P}\right)\right)\right] \cdot F c_{p}
$$

[Equation 3.3.8]

$$
W F_{\text {wasted }}=\sum_{p=1}^{199}\left[\left(I W F_{p} \cdot X_{p}\right)+\left(W F_{p} \cdot\left(100-X_{p}\right)\right)\right] \cdot F W_{p}
$$

[Equation 3.3.9]

where $W F_{p}$ is the WF value of a product $p$ produced in Spain ( $\left.\mathrm{m}^{3} / \mathrm{ton}\right)$, and, as defined in Equation 3.3.3, $\mathrm{Fc}_{\mathrm{p}}$ and $\mathrm{FW}_{\mathrm{p}}$ are the total food consumption of a product $\mathrm{p}$ on a household basis ( $\mathrm{kg} / \mathrm{cy}$ ) and the total food waste of a product $\mathrm{p}$ on a household basis ( $\mathrm{kg} / \mathrm{cy}$ ) respectively, in Spain. 


\subsection{COMPARISON OF THE MEDITERRANEAN DIET AND CURRENT FOOD CONSUMPTION PATTERNS IN SPAIN FROM A NUTRITIONAL AND WATER PERSPECTIVE}

The methodology used in this study largely builds on the previous research one (Chapter 3.3: Assessing the food consumption and waste in Spanish households, and their water implications within and beyond national borders), described above. Table 3.2 summarizes and describes data sources used for composition, the WF, the nutritional and the NWP analysis of both diets.

\subsubsection{COMPOSITION ANALYSIS}

Data on current food consumption per household were collected for the period October 2014 to September 2015 and obtained from the titled "Consumption, Commercialization and Food Distribution: Household Consumption" Database Program (Ministerio de Agricultura Alimentación y Medio Ambiente, 2016a).

The dataset was analyzed in the last research study, resulting in a total per capita consumption of $655 \mathrm{~kg} /$ capita year (i.e. kg/cy) broken down into 199 food products.

The Mediterranean diet in Spanish households was estimated again assuming that per capita consumption was $655 \mathrm{~kg} / \mathrm{cy}$, albeit with a different proportion of food product consumption, i.e., taking into account the food pyramid recommendations by the Mediterranean Diet Foundation and its research studies (Bach-Faig et al., 2011a). This pyramid describes the number of recommended servings of each food product and/or group per day (or week) in a traditional Mediterranean diet.

For ease of assessment, food products (199 in total) were divided into 10 different groups. Bach-Faig et al. (2011a) describe the criteria for grouping these food items but refer mainly to the number of recommended servings per day/week as part of a Mediterranean diet. Food items like vegetables and fruits are grouped together not just because they are vegetable food products, but because the recommended daily intake is similar for both types of food items. 
Table 3.2. Data description and sources for the comparison of the Mediterranean diet and current food consumption patterns in Spain from a nutritional and water perspective.

\begin{tabular}{|c|c|c|c|}
\hline Dataset & Description & Characteristics & Source \\
\hline $\begin{array}{l}\text { Current Food } \\
\text { consumption }\end{array}$ & $\begin{array}{l}\text { Estimation of actual } \\
\text { household food } \\
\text { consumption (Oct. } 2014 \text { - } \\
\text { Sept. 2015) }\end{array}$ & $\begin{array}{l}\text { Results from national household surveys (total } \\
\text { consumption: } 655 \mathrm{~kg} / \text { capita year) broken down by } \\
\text { food products (199) and assessed in previous } \\
\text { research by Blas et al. (2018) }\end{array}$ & $\begin{array}{l}\text { Spanish Ministry of Agriculture, Food and } \\
\text { Environment (Ministerio de Agricultura } \\
\text { Alimentación y Medio Ambiente, 2016a) }\end{array}$ \\
\hline Mediterranean Diet & $\begin{array}{l}\text { Estimation of the } \\
\text { Mediterranean diet in } \\
\text { households ( Oct. } 2014 \text { - } \\
\text { Sept. 2015) }\end{array}$ & $\begin{array}{l}\text { Assessment of the per capita consumption of the } \\
199 \text { products ( } \mathrm{kg} / \mathrm{year} \text { ) according to the } \\
\text { recommended weekly servings of the traditional diet } \\
\text { pyramid }\end{array}$ & $\begin{array}{l}\text { Mediterranean Diet Foundation and its } \\
\text { research studies (Bach-Faig et al., 2011a) }\end{array}$ \\
\hline $\begin{array}{l}\text { Nutritional values of } \\
\text { food products }\end{array}$ & $\begin{array}{l}\text { Multidimensional nutritional } \\
\text { database }\end{array}$ & $\begin{array}{l}\text { Nutritional value (energy, proteins, fats, } \\
\text { carbohydrates, fiber, water, minerals and vitamins) } \\
\text { per } 100 \mathrm{~g} \text { of each of the } 199 \text { consumed products }\end{array}$ & $\begin{array}{l}\text { Spanish Agriculture Ministry and Spanish } \\
\text { Nutrition Foundation databases (FEN, } \\
\text { 2018) }\end{array}$ \\
\hline $\begin{array}{l}\text { Export and imports of } \\
\text { food products }\end{array}$ & $\begin{array}{l}\text { Database of food product } \\
\text { import and exports (Oct. } \\
\text { 2014-Sept. 2015) }\end{array}$ & $\begin{array}{l}\text { Tons of the } 84 \text { most consumed products ( } 70 \% \text { of } \\
\text { final current consumption) imported to Spain per } \\
\text { year (and their origin) assessed in previous research } \\
\text { by Blas et al. ( } 2018 \text { ) }\end{array}$ & $\begin{array}{l}\text { Ministry of Economy and } \\
\text { Competitiveness (Ministerio de } \\
\text { Economía, 2016) }\end{array}$ \\
\hline $\begin{array}{l}\text { National food } \\
\text { production }\end{array}$ & $\begin{array}{l}\text { National production of every } \\
\text { food product over a one- } \\
\text { year period (Oct. 2014-Sept. } \\
\text { 2015) }\end{array}$ & $\begin{array}{l}\text { Tons/year of the } 84 \text { most consumed products ( } 70 \% \\
\text { of final current consumption) produced in Spain } \\
\text { assessed in previous research by Blas et al. (2018) }\end{array}$ & $\begin{array}{l}\text { (Asemac, 2016; ASOZUMOS, 2016; FAO, } \\
\text { 2015; INE, 2016; Ministerio de } \\
\text { Agricultura Alimentación y Medio } \\
\text { Ambiente, 2016c, 2016b; WPTC, 2016) }\end{array}$ \\
\hline $\begin{array}{l}\text { Water Footprint of } \\
\text { crop and livestock } \\
\text { products }\end{array}$ & $\begin{array}{l}\text { WF values of all food } \\
\text { products (average time } \\
\text { series 1996-2005) }\end{array}$ & $\begin{array}{l}\text { Values for green, blue and grey WF in } \mathrm{m}^{3} / \text { ton of all } \\
199 \text { agricultural and livestock products }\end{array}$ & (Mekonnen and Hoekstra, 2011, 2012) \\
\hline
\end{tabular}


The groups, with their recommended weekly servings and the percentage of the total diet for which they account, were:

$>$ (1) Fruits and vegetables (70 servings, 41.5\%)

$>$ (2) Cereals, olive oil and healthy drinks (52 servings, 31\%)

$>$ (3) Olives, nuts, seeds and condiments (16 servings, 9.5\%)

$>$ (4) Dairy products (14 servings, $8 \%$ )

$>$ (5) Eggs and legumes (6 servings, 3.5\%)

$>$ (6) Fish and seafood (3 servings, 2\%)

$>$ (7) Potatoes (2-3 servings, $1.5 \%$ )

$>$ (8) White meat and vegetable fats (2 servings, 1.3\%)

(9) Red or processed meat (1-2 servings, 1\%)

$>$ (10) Sugar, sweets, sauces and beverages (1 serving, 0.7\%)

Therefore, we assessed 168 servings per week equivalent to 24 per day and 8 per meal (breakfast, lunch, and dinner). To calculate the exact per capita consumption of each food product in $\operatorname{Med}_{\text {Diet }}\left(M_{p}\right)$ in $\mathrm{kg} / \mathrm{cy}$, we used Equation 3.4.1:

$$
\mathrm{M}_{\mathrm{p}}=\mathrm{FC}_{\mathrm{p}} \cdot \mathrm{R}_{\mathrm{MD} p}
$$

[Equation 3.4.1]

where $F C_{p}$ is the current per capita consumption of a food product $p(\mathrm{~kg} / \mathrm{cy}$ ) in the Current $_{\text {Diet }}$ (Equations 3.3.3 and 3.3.8), and $R_{M D} p$ is the recommended percentage consumption of a product $\mathrm{p}$ in relation to the total diet according to the Med Diet $_{\text {pyramid }}$ guidelines, as explained and detailed above.

\subsubsection{NUTRITIONAL ANALYSIS}

The nutritional analysis was conducted using data from the Spanish Ministry of Agriculture and Spanish Nutrition Foundation databases (FEN, 2018). Data for eight nutritional components were used for all food products within the diet (using information about similar products to estimate products with missing data). The eight analyzed nutritional values were: energy (kcal), proteins $(\mathrm{g})$, fats $(\mathrm{g})$, carbohydrates $(\mathrm{g})$, fiber $(\mathrm{g})$, water (g), minerals ( $\mathrm{mg}$ ) and vitamins ( $\mathrm{mg}$ ).

Data on nutritional values were given per 100 grams of product. Total lipids were the sum of saturated, monounsaturated and polyunsaturated fatty acids, v-3, C18: 2 linoleic ( $v-6)$ and cholesterol. Minerals were the sum of calcium, iron, iodine, magnesium, zinc, sodium, potassium, phosphorus, and selenium. 
Finally, vitamins were the sum of: thiamine, riboflavin, niacin equivalent, vitamin B6, folates, vitamin B12, vitamin C, vitamin A (retinol), vitamin D and vitamin E.

The multidimensional nutritional analysis was performed by multiplying each product's nutritional value $\left(N_{p}\right)$ and its consumption value: $F C_{p}$ for Current $_{\text {Diet }}$ diet and $M_{p}$ for MedDiet. The sum of all 199 products accounts for the nutritional diet value for both Current $_{\text {Diet }}$ and Med Diet.

\subsubsection{Diet'S WATER FoOTPRINT}

We estimated the WF of the current food consumption and Mediterranean Diet for Spanish households using as a reference period from 1 October 2014 to 30 September 2015.

The current food consumption taking into account the proportion of food consumed that is nationally produced and imported (and the water needed to produce it), was already done in the last study (section 3.3.2: Imported water and origin of food products and 3.3.3: Water footprint of food consumption and waste).

We also used equation 3.3.5, 3.3.6, 3.3.7 and finally, the equation 3.3.8, that estimates the WFcon that in this study is called WFcurrent. Finally, for the WFs for Mediterranean Diet (WF $F_{\text {Med }}$ ) measured in liters per capita day (liters/cd) were calculated using:

$$
W F_{M e d}=\sum_{p=1}^{199}\left[\left(I W F_{P} \cdot X_{P}\right)+\left(W F_{p} \cdot\left(100-X_{P}\right)\right)\right] \cdot M_{p}
$$

[Equation 3.4.2]

Where $W F_{p}$ is the Spanish national WF value (Green, Blue or Grey) of a product $p$ (liters $/ \mathrm{kg}$ ) as explained in equation 3.3.8, and, as defined before, $M_{p}$ is the recommended Mediterranean Diet consumption of a product $\mathrm{p}$ ( $\mathrm{kg} / \mathrm{capita}$ day). 


\subsubsection{NUTRITIONAL WATER PRODUCTIVITY ASSESSMENT}

Nutritional Water Productivity (NWP) links water and nutrition. To calculate green and blue NWP of each nutritional component $\mathrm{n}$, for a diet $\mathrm{i}$, we used:

$$
N W P_{n i}=\sum_{p=1}^{199} \frac{\left(N_{P} \cdot F_{P}\right)}{\left[\left(I_{P} \cdot I W F_{P} \cdot X_{P}\right)+\left(P_{p} \cdot W F_{P} \cdot\left(100-X_{P}\right)\right)\right] \cdot H_{i}}
$$

[Equation 3.4.3]

Where $N_{p}$ is the nutritional value per $k g$ of a product $p, F_{p}$ is the food consumption $\left(F C_{p}\right.$ in Current Diet $_{\text {or }} \mathrm{M}_{\mathrm{p}} \mathrm{Med}_{\text {Diet }}$ ) of a product $\mathrm{p}$ (in $\mathrm{kg} / \mathrm{cy}$ ). As defined in Equation 3.3.5; $\mathrm{I}_{\mathrm{p}}$ is the total imported value of a product $p$ in a year $(\mathrm{kg}), \mathrm{P}_{\mathrm{p}}$ is the national production of a product $p$ in a year $(\mathrm{kg})$, and $X_{p}$ is the import factor of a product $p(\%)$. IWF $F_{p}$ and $W F_{p}$ are the imported and national water footprints of a product $p(1 / \mathrm{kg})$ respectively, as explained in Equations 3.3.6, 3.3.7 and 3.3.8.

The green NWP was calculated using only green $I W F_{p}$ and $N W F_{p}$ values, and the blue $N W P$, using the blue $I W F_{p}$ and $N W F_{p}$ values. For the sake of consistency, we analyzed household food consumption only, applying the household consumption factor $\mathrm{H}_{i}$. Accordingly, we only took into account the proportion of food that was consumed at home, excluding food consumed at restaurants, bars, workplaces... For this analysis, $\mathrm{H}_{\mathrm{i}}$ was estimated at 0.75 (75\%), based on average data collected by the Spanish Ministry of Agriculture (Ministerio de Agricultura Alimentación y Medio Ambiente, 2016a) for the period 1987-2006. $\mathrm{H}_{\mathrm{i}}$ is household consumption factor is explained already in equation 3.3.1. 


\section{RESULTS AND DISCUSSION}

\subsection{Evaluating the Water Footprint of the Mediterranean and American Diets}

\subsubsection{RESULTS}

The $W F_{\text {menu }}$ and $W F_{\text {diet }}$ of the recommended Mediterranean and USDAr diets, as well as the potential shift in dietary habits, are shown in Figure 4-1 for Spain (a) and the US (b). The $W F_{\text {menu }}$ and $W F_{\text {diet }}$ of USDAr diet are higher than the Mediterranean diet, irrespectively of the products' origin (Spain or US).
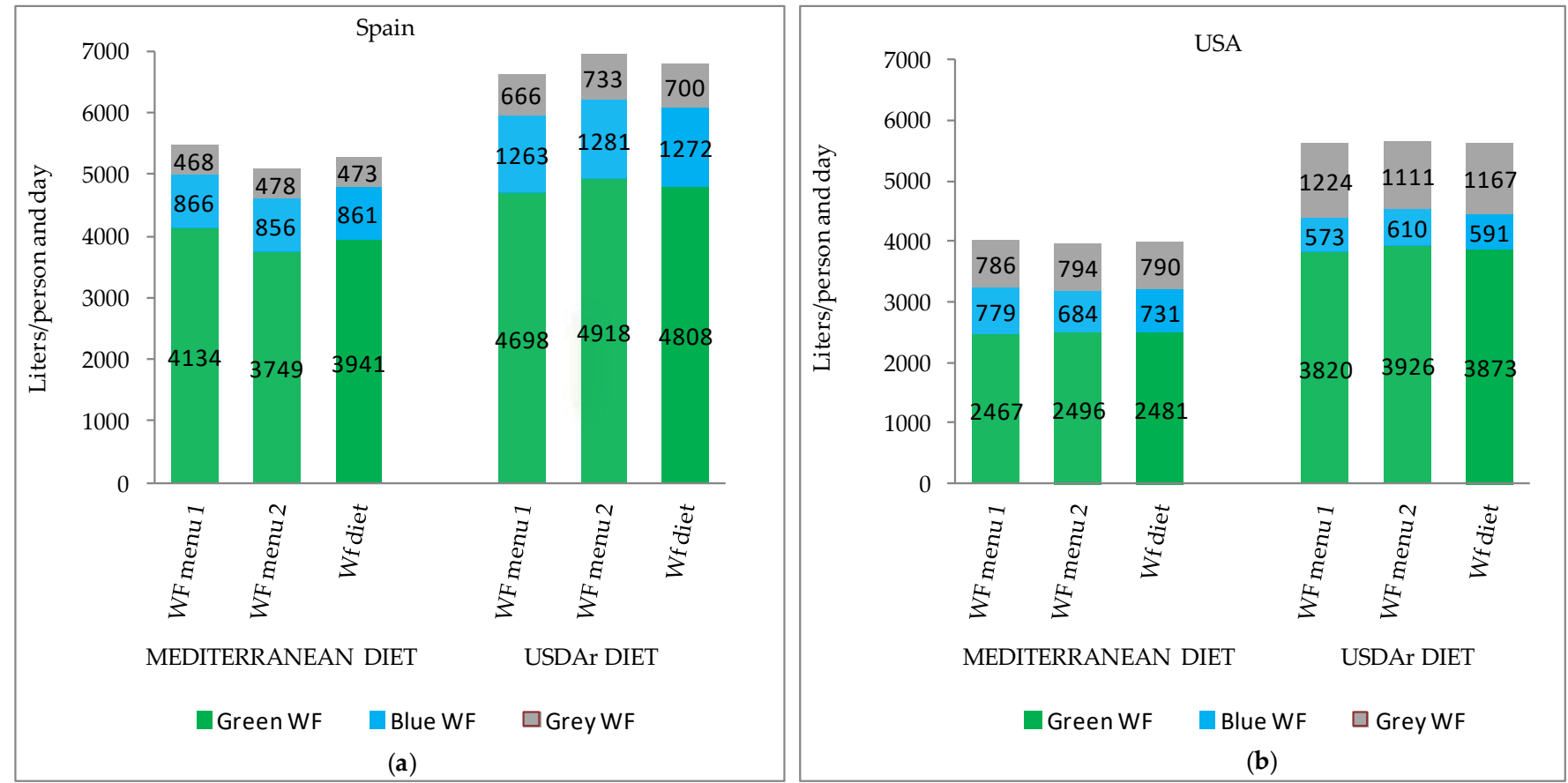

Figure 4-1. Green, blue and grey water footprint (WF) for WFmenu1, WFmenu2 and the total WF diet of the Mediterranean diet (WFdiet), and WFmenu1, WFmenu2 and the total

WF diet of USDAr diet (WFdiet), for (a) Spain and (b) the US. Source: Own elaboration

In Spain, the total $W F_{\text {diet }}$ of the Mediterranean diet is 5276 liters per capita day (liters/cd), but adopting a USDAr diet will increase the total $W F_{\text {diet }}$ nearly $29 \%$, up to 6780 liters/cd. The majority of this increase results from the rise in green water, followed by blue water, and to a lesser extent grey water. In the US, the total WF diet of the USDA $r$ is 5632 Liters per capita day. Shifting towards a Mediterranean diet (4003 Liters per capita day), will decrease the total $W_{\text {diet }}$ by $29 \%$. Larger savings will be achieved in terms of green water 
$(-1392$ liters/cd) and grey water. However, in this diet-shift scenario blue WF will increase by $24 \%$.

Green WF accounted for the largest share of both WFmenu and WF diet in the two countries. In Spain, green WF contributes to $75 \%$ of $W F_{\text {diet }}$ for the Mediterranean diet and $71 \%$ for the USDAr diet. In the US, green WF accounted for $62 \%$ of WF diet in the Mediterranean and $69 \%$ in the USDAr diet. Blue WF was the second largest fraction in WF diet in Spain for both Mediterranean (16\%) and USDAr diet (19\%). On the other hand, grey WF accounted for the second largest fraction of WF $\mathrm{Wiet}_{\text {in }}$ in the US for Mediterranean (20\%) and USDAr diets (21\%). If we took into account, only the blue and green WF components of WFmenu and $W F_{\text {diet }}$ (consumptive WF) in order to discern the impacts of water resources quantity, there would be water savings equivalent to 1277 liters/cd in Spain by consuming a Mediterranean diet instead of an USDAr diet. Similar values were obtained in the US for green and blue WFs, where changing from an USDAr to a Mediterranean diet will imply a net reduction of 1252 liters per capita day.

Comparing the $\mathrm{WF}_{\text {diet }}$ in the two different countries for the same diet revealed that, while the Mediterranean diet is more efficient in terms of water consumption in all cases, adopting a Mediterranean diet in the US would deliver greater water savings (up to $24 \%$ or 1273 liters/cd in comparison with the same diet consumed in Spain). This is due to the greater water productivity of US's agriculture. On the other hand, USDAr diet in Spain will increase the $\mathrm{WF}_{\text {diet }} 20 \%$ (1148 liters/cd) in comparison with the consumption of this diet in the US. Figure 4-2 shows the contribution of the different groups of products to the total WF diet in Spain and the US. Dairy products, oil and vegetable fats, and meat, fish and animal fats accounted for the $68 \%$ of the green component of the Mediterranean diet in Spain (up to 2662 liters/cd) (Figure 4-2a). A shift towards an American diet of Spanish consumers would increase the consumption of dairy and meat, fish and animal products groups by $30 \%\left(+547\right.$ liters/cd) and therefore enlarge the green $W F_{\text {diet }}$ up to 4808 liters/cd. Legumes, cereals and potatoes, and eggs also represent a significant share of

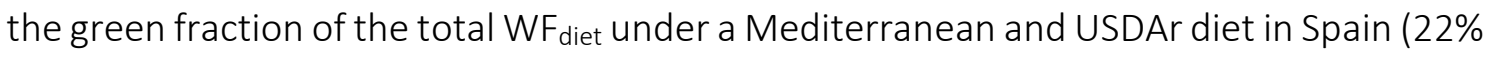
and $19 \%$ respectively).

Changing the consumption patterns in the US and adopting a Mediterranean diet would deliver significant green water savings (Figure 4-2a). Many of these water savings are related to lower green WF values associated with oil and vegetable fats (70\% lower, 407 liters/cd less), meat and fish products (22\% lower, 211 liters/cd less) and cocoa, chocolate and vanilla (93\% lower, 257 liters/cd less) in the Mediterranean diet. The share of blue WF among product groups is more evenly distributed in the case of the Mediterranean diet in Spain (Figure 4-2b). On the other hand, legumes and nuts, and cereals and potatoes groups account for the $45 \%$ of the blue component of the USDAr diet (572 liters/cd). 


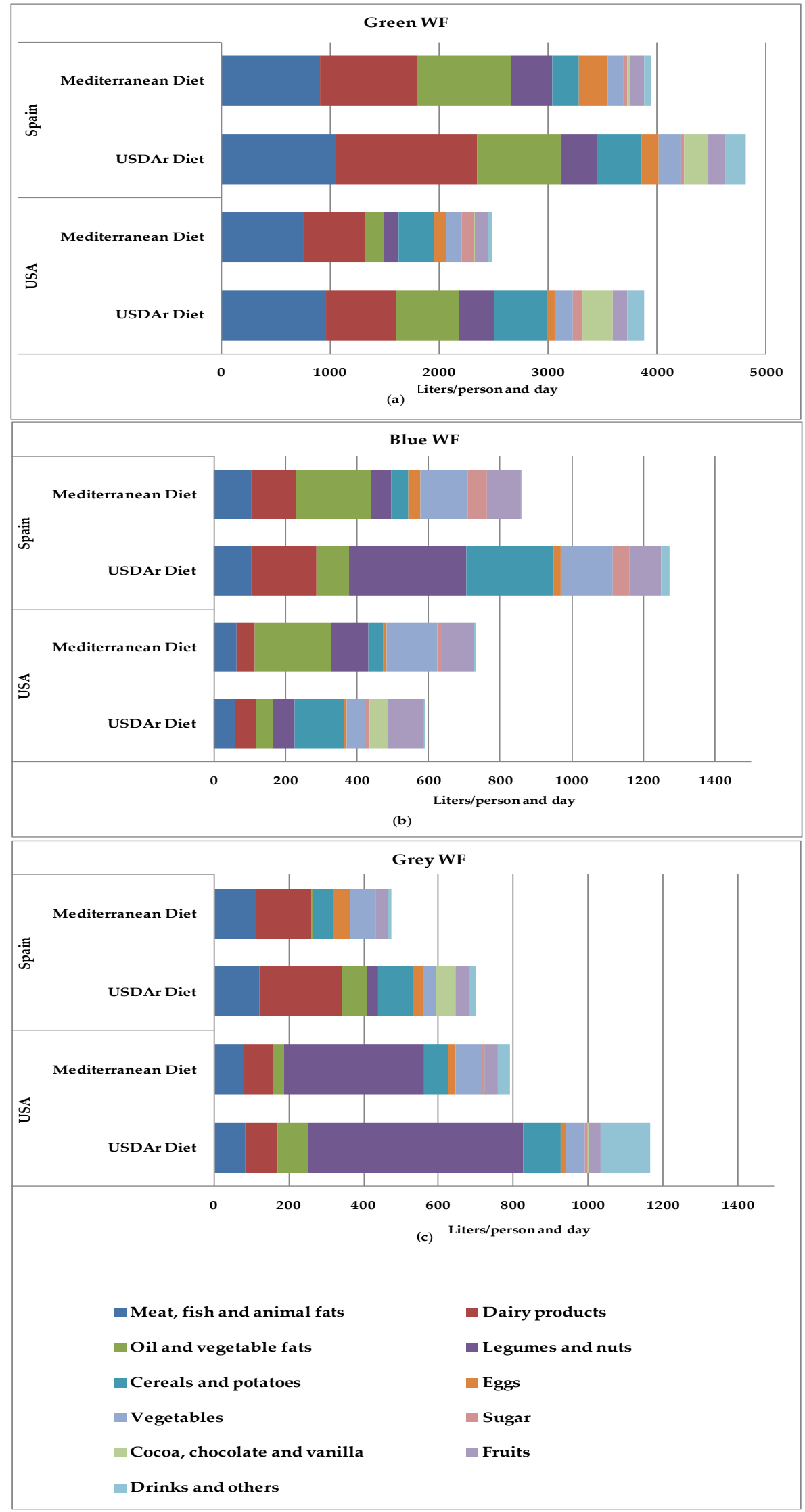

Figure 4-2. Characterization of the green (a), blue (b) and grey (c) components of the $W F_{\text {diet }}$ of the Mediterranean and USDAr diets in Spain and the US for the different product groups. Source: own elaboration. 
So the largest differences in terms of blue water WF among diets in Spain are due to the higher water consumption of legumes and nuts (almost six times higher, +273 liters/cd) as well as cereals and potatoes (almost five times higher, +195 liters/cd) in the USDAr diet in comparison with the Mediterranean one.

In the case of US, the Mediterranean diet has higher blue WF than USDAr diet. Legumes and nuts, oil and vegetable fats, and vegetables account for $62 \%$ of the blue component of the Mediterranean diet in the US (up to 455 liters/cd). A shift towards a Mediterranean diet of American consumers would increase the blue WF of these products groups: legumes and nuts (68\% higher, +42 liters/cd), oil and vegetable fats (nearly five time's higher, + 166 liters/cd) and vegetables (nearly three time's higher, + 89 liters/cd).

Concerning grey WF (Figure 4-2c) in both countries, the USDAr diet has higher values than the Mediterranean one, especially in the US. Meat, fish and animal fats and dairy products account for $55 \%$ of the grey WF of the Mediterranean diet in Spain $(260$ liters/cd). Consuming an USDAr diet would lead to an increase of dairy products (46\% higher, 70 liters/cd) and oil and vegetable fats (35 times higher, 67 liters/cd). In addition, very significantly, the WF of cocoa, chocolate, and vanilla group is higher and increases up to 480 times in changing to an USDAr diet (53 liters/cd). In the case of the US, the legumes and nuts group alone accounts for almost $50 \%$ of the grey component of the USDAr diet (576 liters/cd). A change to a Mediterranean diet would afford a 35\% reduction (202 liters/cd) in this product group.

The analysis of the individual products' WF reveals that a limited number of products contribute the most to the green, blue, grey and total WF diet account for up to $36 \%-46 \%$ of the total in both countries and dietary options. Table 4.1 and Table 4.2 show the five products that contribute the most to the green, blue, grey and total WF $F_{\text {diet }}$ for both diets and countries. Olive oil is the product that accounts the most to the $W F_{\text {diet }}$ of the Mediterranean diet, in both Spain and the US, as shown in Tables 4.1 and 4.2 respectively. On the other hand, in the USDAr diet, semi-skimmed milk is the product that accrues the largest share of the $W F_{\text {diet }}(16 \%$, equivalent to 1085 liters per capita day) in Spain (Table 4.1). While in the US (Table 4.2), the product that claims the largest WF $F_{\text {diet }}$ is beef meat $(14 \%, 789$ liters/cd).

Most of the products that influence the most for green, blue, and grey (and thus in total $W F_{\text {diet }}$ ) for both dietary options and countries originate from only three products groups: (a) meat, fish and animal fats; (b) dairy products; and (c) oils and vegetable fats. Moreover, products from the group of legumes and nuts account for the major part of the grey WF for both diets in the US. 
Table 4.1. The five products that contribute the most in liters per capita day (liters/cd) and \% to the green, blue, grey and total WF $F_{\text {diet }}$ for the Mediterranean and USDAr diets in Spain.

\begin{tabular}{|c|c|c|c|c|c|c|c|c|c|c|c|}
\hline \multicolumn{12}{|c|}{ Mediterranean Diet } \\
\hline \multicolumn{3}{|c|}{ Green WF } & \multicolumn{3}{|c|}{ Blue WF } & \multicolumn{3}{|c|}{ Grey WF } & \multicolumn{3}{|c|}{$W F_{\text {diet }}$} \\
\hline Product & liters/cd & $\%$ & Product & liters/cd & $\%$ & Product & liters/cd & $\%$ & Product & liters/cd & $\%$ \\
\hline Olive oil & 867 & $22 \%$ & Olive oil & 207 & $24 \%$ & Milk & 61 & $13 \%$ & Olive oil & 1055 & $20 \%$ \\
\hline Milk & 355 & $9 \%$ & Milk & 52 & $6 \%$ & Eggs & 43 & $9 \%$ & Milk & 475 & $9 \%$ \\
\hline Beef meat & 276 & $7 \%$ & Sugar & 52 & $6 \%$ & Cheese & 33 & $7 \%$ & Eggs & 316 & $6 \%$ \\
\hline Eggs & 236 & $6 \%$ & Asparagus & 43 & $5 \%$ & Beef meat & 28 & $6 \%$ & Beef meat & 316 & $6 \%$ \\
\hline Cheese & 197 & $5 \%$ & Eggs & 34 & $4 \%$ & Chicken & 28 & $6 \%$ & Cheese & 264 & $5 \%$ \\
\hline Rest & 2010 & $51 \%$ & Rest & 474 & $55 \%$ & Rest & 279 & $59 \%$ & Rest & 2847 & $54 \%$ \\
\hline \multicolumn{12}{|c|}{ USDAr Diet } \\
\hline \multicolumn{3}{|c|}{ Green WF } & \multicolumn{3}{|c|}{ Blue WF } & \multicolumn{3}{|c|}{ Grey WF } & \multicolumn{3}{|c|}{$W F_{\text {diet }}$} \\
\hline Product & liters/cd & $\%$ & Product & liters/cd & $\%$ & Product & liters/cd & $\%$ & Product & liters/cd & $\%$ \\
\hline SK mik ${ }^{1}$ & 817 & $17 \%$ & Soymilk & 267 & $21 \%$ & SK milk ${ }^{1}$ & 140 & $20 \%$ & SK milk ${ }^{1}$ & 1084 & $16 \%$ \\
\hline Beef meat & 529 & $11 \%$ & Oats & 165 & $13 \%$ & Margarine & 70 & $10 \%$ & Beef meat & 610 & $9 \%$ \\
\hline Margarine & 385 & $8 \%$ & SK milk ${ }^{1}$ & 115 & $9 \%$ & Beef meat & 56 & $8 \%$ & Margarine & 542 & $8 \%$ \\
\hline Chicken & 192 & $4 \%$ & Sesame & 76 & $6 \%$ & Vanilla & 49 & $7 \%$ & Oats & 407 & $6 \%$ \\
\hline Oats & 192 & $4 \%$ & Margarine & 51 & $4 \%$ & Oats & 42 & $6 \%$ & Soymilk & 339 & $5 \%$ \\
\hline Rest & 2692 & $56 \%$ & Rest & 598 & $47 \%$ & Rest & 343 & $51 \%$ & Rest & 3796 & $56 \%$ \\
\hline
\end{tabular}

${ }^{1}$ SK milk = Semi-skimmed milk. 
Table 4.2. The five products that contribute the most in liters per capita day (liters/cd) and \% to the green, blue, grey and total WF $F_{\text {diet }}$ for the Mediterranean and USDAr diets in the US.

\begin{tabular}{|c|c|c|c|c|c|c|c|c|c|c|c|}
\hline \multicolumn{12}{|c|}{ Mediterranean Diet } \\
\hline \multicolumn{3}{|c|}{ Green WF } & \multicolumn{3}{|c|}{ Blue WF } & \multicolumn{3}{|c|}{ Grey WF } & \multicolumn{3}{|c|}{$W F_{\text {diet }}$} \\
\hline Product & liters/cd & $\%$ & Product & liters/cd & $\%$ & Product & liters/cd & $\%$ & Product & liters/cd & $\%$ \\
\hline Milk & 323 & $13 \%$ & Olive oil & 212 & $29 \%$ & Chickpeas & 126 & $16 \%$ & Olive oil & 400 & $10 \%$ \\
\hline Beef meat & 298 & $12 \%$ & Almonds & 51 & $7 \%$ & Almonds & 79 & $10 \%$ & Milk & 400 & $10 \%$ \\
\hline Olive oil & 174 & $7 \%$ & Asparagus & 44 & $6 \%$ & Lentils & 63 & $8 \%$ & Beef meat & 320 & $8 \%$ \\
\hline Bread & 124 & $5 \%$ & Hazelnuts & 37 & $5 \%$ & Hazelnuts & 55 & $7 \%$ & Chickpeas & 160 & $4 \%$ \\
\hline Flour & 124 & $5 \%$ & Milk & 29 & $4 \%$ & Milk & 47 & $6 \%$ & Pork Meat & 160 & $4 \%$ \\
\hline Rest & 1439 & $58 \%$ & Rest & 358 & $49 \%$ & Rest & 419 & $47 \%$ & Rest & 2562 & $64 \%$ \\
\hline \multicolumn{12}{|c|}{ USDAr Diet } \\
\hline \multicolumn{3}{|c|}{ Green WF } & \multicolumn{3}{|c|}{ Blue WF } & \multicolumn{3}{|c|}{ Grey WF } & \multicolumn{3}{|c|}{$W F_{\text {diet }}$} \\
\hline Product & liters/cd & $\%$ & Product & liters/cd & $\%$ & Product & liters/cd & $\%$ & Product & liters/cd & $\%$ \\
\hline Beef meat & 736 & $19 \%$ & Oats & 77 & $13 \%$ & Beans & 268 & $23 \%$ & Beef meat & 788 & $14 \%$ \\
\hline SK milk ${ }^{1}$ & 387 & $10 \%$ & Vanilla & 53 & $9 \%$ & Chickpeas & 152 & $13 \%$ & SK milk ${ }^{1}$ & 451 & $8 \%$ \\
\hline Vegetable oil & 232 & $6 \%$ & Apple juice & 35 & $6 \%$ & Coffee & 128 & $11 \%$ & Beans & 338 & $6 \%$ \\
\hline Margarine & 194 & $5 \%$ & SK milk ${ }^{1}$ & 35 & $6 \%$ & Lentils & 105 & $9 \%$ & Oats & 282 & $5 \%$ \\
\hline Oats & 194 & $5 \%$ & Rice & 35 & $6 \%$ & SK milk ${ }^{1}$ & 58 & $5 \%$ & Coffee & 225 & $4 \%$ \\
\hline Rest & 2131 & $55 \%$ & Rest & 355 & $60 \%$ & Rest & 455 & $39 \%$ & Rest & 3548 & $63 \%$ \\
\hline
\end{tabular}

${ }^{1}$ SK milk = Semi-skimmed milk. 


\subsubsection{DISCUSSION}

USDAr diet has a greater average consumption quantity of dairy products: 756 grams/capita day $(\mathrm{g} / \mathrm{cd})$ than the Mediterranean diet $(405 \mathrm{~g} / \mathrm{cd})$. In addition, the USDAr diet has a greater share of legumes and nuts daily intake $(246 \mathrm{~g} / \mathrm{cd}$, in comparison with $89 \mathrm{~g} / \mathrm{cd}$ in the Mediterranean diet). On the other hand, in the Mediterranean diet, the intake quantity of vegetables is higher ( $1021 \mathrm{~g} / \mathrm{cd}$ versus $613 \mathrm{~g} / \mathrm{cd}$ in USDAr diet), as well as fruits $(624 \mathrm{~g} / \mathrm{cd}$ in the Mediterranean diet in comparison with the $545 \mathrm{~g} / \mathrm{cd}$ of the USDAr diet).

Regarding meat, fish, and animal fats food group, they have similar consumption rates of meat and animal fats: $187 \mathrm{~g} / \mathrm{cd}$ in the Mediterranean diet and $173 \mathrm{~g} / \mathrm{cd}$ in the USDAr one. However, in the Mediterranean diet the consumption of fish is much higher (146 versus $48 \mathrm{~g} / \mathrm{cd}$ ), which significantly reduces the $W F_{\text {diet }}$ linked to the consumption of animal proteins. In short, the Mediterranean diet relies on a larger intake of vegetables, fruits, and fish, while in the USDAr diet the fraction of dairy, legumes and nuts products is larger.

\section{Consumption Patterns: Water Footprint of Mediterranean and USDAr Diets}

In both countries, adopting a Mediterranean diet would lead to major WF reductions per person. In Spain, maintaining a Mediterranean diet will save up to 1504 liters/cd ( $\approx 29 \%)$; while in the US, shifting into a Mediterranean diet would deliver even greater benefits (net WF reductions of 1629 liters/cd, equivalent to 29\%). The Mediterranean summer menu (menu 2) has a total WF 7\% smaller than the winter menu (menu 1) in Spain and $1.5 \%$ in the US. These differences can be attributed to the larger calorie content of the winter menu since the proportion of food groups is similar in the two menus. Our results stand within the ranges of Vanham et al. (2013a), who found that healthy diets lead to water savings ranging between $3 \%$ and $30 \%$. Moreover, our results are consistent with those studies where diets based on the consumption of vegetables and fruits (Jalava et al., 2014; López-Gunn et al., 2012; Pimentel and Pimentel, 2003; Tilman and Clark, 2014; Vanham, 2013; Vanham et al., 2013b, 2013a) or totally vegetarian (Harold J Marlow et al., 2009; Reijnders and Soret, 2003) have a smaller WF compared to animal productsbased or non-vegetarian diets.

Some authors have shown similar water savings (up to 33\%) when western dietary patterns are replaced by the adoption of a Mediterranean diet (Sáez-Almendros et al., 2013). Other comparisons between the Mediterranean recommended diet and other western meat-based dietary patterns have been reported (López-Gunn et al., 2012; SáezAlmendros et al., 2013; Tilman and Clark, 2014), concluding also that there are major water savings using a Mediterranean diet. However, little is known about comparisons with other real and officially recommended diets. 


\section{Products' Origins Matter: Water Footprints in Spain and US}

This study also shows that production factors also explain part of the changes in $W_{\text {diet }}$ beyond the shifts in diets. As shown in Figure 4-1, a shift towards a Mediterranean diet in the US will decrease the total WF diet up to 4003 liters/cd, a value below the WF $F_{\text {diet }}$ calculated for a Mediterranean diet in Spain (5276 liters/cd). Also, looking only at the consumptive fraction of the $W F_{\text {diet }}$ (green $W F+$ blue WF), the lowest values appear for the Mediterranean diet in the US. This means that not only consumption patterns but also products' origins (prevailing climate and production conditions) are very significant factors to be taken into account for minimizing WFs. It also implies that the mix of dietary patterns based on the consumption of vegetables, fish and fruits, followed by improved production conditions (i.e., lower WF), can contribute to achieving major water savings.

In countries like Spain, high values for green and blue WF can be explained because of the prevailing semi-arid climate conditions. Several studies have shown this close relationship between drier climate conditions and higher values of green and blue WFs (Vanham et al., 2013a, 2013b; Vanham and Bidoglio, 2015). High temperatures and low rainfall contribute to higher WF in liters $/ \mathrm{kg}$ of products, because of the lower yields under large production areas (Olesen et al., 2011). Further, in semi-arid conditions, there is a greater need for irrigation, which increases the blue WF (Vanham et al., 2013a; Wriedt et al., 2009).

Our results demonstrate that the green and blue components of the $W_{\text {diet }}$ are higher in Spain compared to the US's regardless of the type of diet. These results are mainly due to the differences of green WF values in the US in comparison with Spain of oil and vegetable fats in the Mediterranean diet (80\% lower in the US, -688 liters/cd), and because the dairy products in the USDAr diet (51\% lower in the US, -661 liters/cd). Despite the differences in water use efficiency across countries, green water is the most important component of the WF $F_{\text {diet }}$ in both countries. These results are in accordance with other studies that concluded the dominance of green water in food production (De Miguel et al., 2015; López-Gunn et al., 2012; Rockström et al., 2009; Salmoral et al., 2011; Vanham, 2013; Vanham et al., 2013b).

The US is also more efficient in the use of blue water in food production. Our results showed that shifting towards a Mediterranean diet in the US is $15 \%$ lower than the blue WF of the Mediterranean diet when consumed in Spain. In addition, adopting an USDAr diet in the US would afford a reduction of blue WF of $54 \%$ in comparison with the adoption of the same diet in Spain. These differences in blue WF are due to the higher efficiency of the US in the production of dairy products and legumes and nuts.

Despite the comparative advantages of the US in terms of blue and green water use in the production of different food items, it is less competitive in terms of grey water use. 
For both diets, the grey component of the $W F_{\text {diet }}$ is up to $67 \%$ higher in the US in comparison with Spain. Legumes and nuts are the food products that show the largest differences in terms of grey water between the two countries. These results are in accordance with those authors that reported high levels of nitrate concentrations in the US farming areas under irrigation, or where the use of nitrogen fertilizers have increased significantly in the last years (Hallberg, 1989; Power and Schepers, 1989).

\section{Olive Oil and national studies}

The calculations of the $W_{\text {diet }}$ in this research are based on global WF datasets for crop and livestock products (Mekonnen and Hoekstra, 2011, 2012). Previous research has found that WF estimations for the same products and countries can differ significantly (Chico et al., 2010; De Miguel et al., 2015; Salmoral et al., 2011). The specific local climate and agricultural practices have a large effect on the WF of products.

Results of this research showed that olive oil is the product accounting for a large share of the Mediterranean WF $F_{\text {diet }}$ in both countries. According to Mekonnen and Hoekstra, the WF of olive oil produced in Spain accounts for $12.1 \mathrm{~m}^{3} /$ liter and $4.7 \mathrm{~m}^{3} /$ liter in the US. Salmoral et al. (2011), conducted a detailed study on the WF of olive oil across the five most important production centers in Spain and found large variations, ranging between $13.1 \mathrm{~m}^{3}$ /liter and $22.4 \mathrm{~m}^{3} /$ liter (Salmoral et al., 2011).

Olive has been cultivated for millennia in the Mediterranean region and has been considered by many authors a symbol of environmental sustainable systems (Blondel, 2006; Duarte et al., 2008; Loumou and Giourga, 2003). These studies also described olive cultivation as a low-intensity production system, and usually associated with old trees, small yields, and receiving low inputs for both labor and materials (Blondel, 2006). These factors (mainly low yields) probably explain the large WF (particularly green water) of olives and olive oil. In view of the above, further research is needed to evaluate the high green WFs.

Other products that have a large influence in the $W F_{\text {diet }}$ are dairy and meat. De Miguel et al. (De Miguel et al., 2015), studied the water footprint of the Spanish pork industry and obtained lower values than those estimated by Mekonnen and Hoekstra (6094 liters/kg versus 7184,3 liters/kg respectively). The wide range of WF estimations for the same products and countries requires a detailed comparison of the values reported by Mekonnen and Hoekstra. Also, more national and local studies are needed. This also requires further research on the calculation of products' WFs at national and more local scales. 


\subsection{FOOD CONSUMPTION AND WASTE IN SPANISH HOUSEHOLDS: WATER IMPLICATIONS WITHIN AND BEYOND NATIONAL BORDERS}

\subsubsection{RESULTS}

\section{Consumption patterns and food waste in Spanish households}

Results show that, on average, total food consumption including drinks for a Spanish household was $655 \mathrm{~kg} /$ capita year (kg/cy). This means that, on an annual basis, average consumption per household is $1,644 \mathrm{~kg}$ and total consumption for the country as a whole is 28.8 million tons. Figure 4-3 shows the average consumption values of the 20 most consumed products (out of 199, accounting for $61 \%$ of total consumption), and the data for the different food groups. The most consumed food group was drinks, sauces, and others, at $153 \mathrm{~kg} / \mathrm{cy}$, equivalent to $23 \%$ of total annual consumption. Other major consumed food groups were fruits $(107 \mathrm{~kg} / \mathrm{cy})$ and dairy products $(104 \mathrm{~kg} / \mathrm{cy})$, both accounting for $16 \%$ of the total.

The values in terms of kilograms consumed per capita year were similar for the following product groups: cereals and potatoes, meat, fish and animal fats, and vegetables; they each accounted for $12 \%$ of total annual consumption. Finally, the least consumed groups ranked by food intake in kilograms were: sugar and sweets, vegetable oil and fats, legumes and nuts, and, finally, eggs.

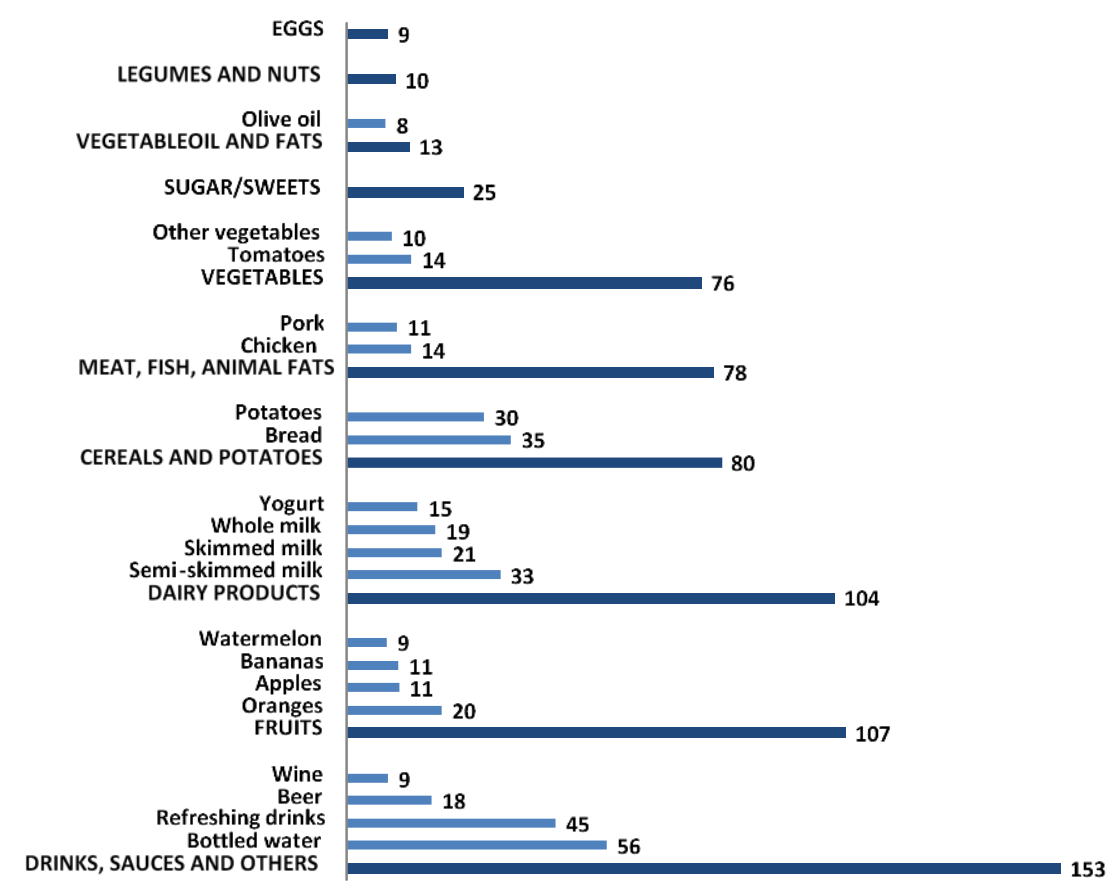

Figure 4-3. Annual consumption ( $\mathrm{kg} /$ person) of all food groups and main products in Spanish households (October 2014 - September 2015). Source: own elaboration. 
With respect to food waste, the amount of annual food waste is $26 \mathrm{~kg} / \mathrm{cy}$ on average. This is equivalent, on an annual basis, to an average food waste per household of $65.3 \mathrm{~kg}$ and a total food waste of nearly 1.14 million tons nationwide. Figure 4-4 shows the 20 most wasted products and data for each food group.

The most wasted product group in Spanish households was fruit $(7.3 \mathrm{~kg} / \mathrm{cy})$ and vegetables $(4.7 \mathrm{~kg} / \mathrm{cy})$, accounting for $28 \%$ and $18 \%$ of total annual household waste, respectively.

Other major product groups with respect to food waste were drinks, sauces and others $(14 \%, 3.5 \mathrm{~kg} / \mathrm{cy})$; cereals and potatoes $(11 \%, 2.8 \mathrm{~kg} / \mathrm{cy})$; dairy products $(10 \%, 2.6 \mathrm{~kg} / \mathrm{cy})$ and meat, fish and animal fats $(8 \%, 2.1 \mathrm{~kg} / \mathrm{cy})$. Finally, the groups with the lowest food waste levels were sugar and sweets, legumes and nuts, eggs and vegetable oils and fats.

Besides, the 20 most wasted products accounted for $47 \%$ of the total annual household food waste. Oranges $(2.6 \mathrm{~kg} / \mathrm{cy})$, bread $(1.5 \mathrm{~kg} / \mathrm{cy})$ and apples $(1.2 \mathrm{~kg} / \mathrm{cy})$ were the individual products with most food waste, accounting for 10, 6 and $5 \%$ of the total, respectively.

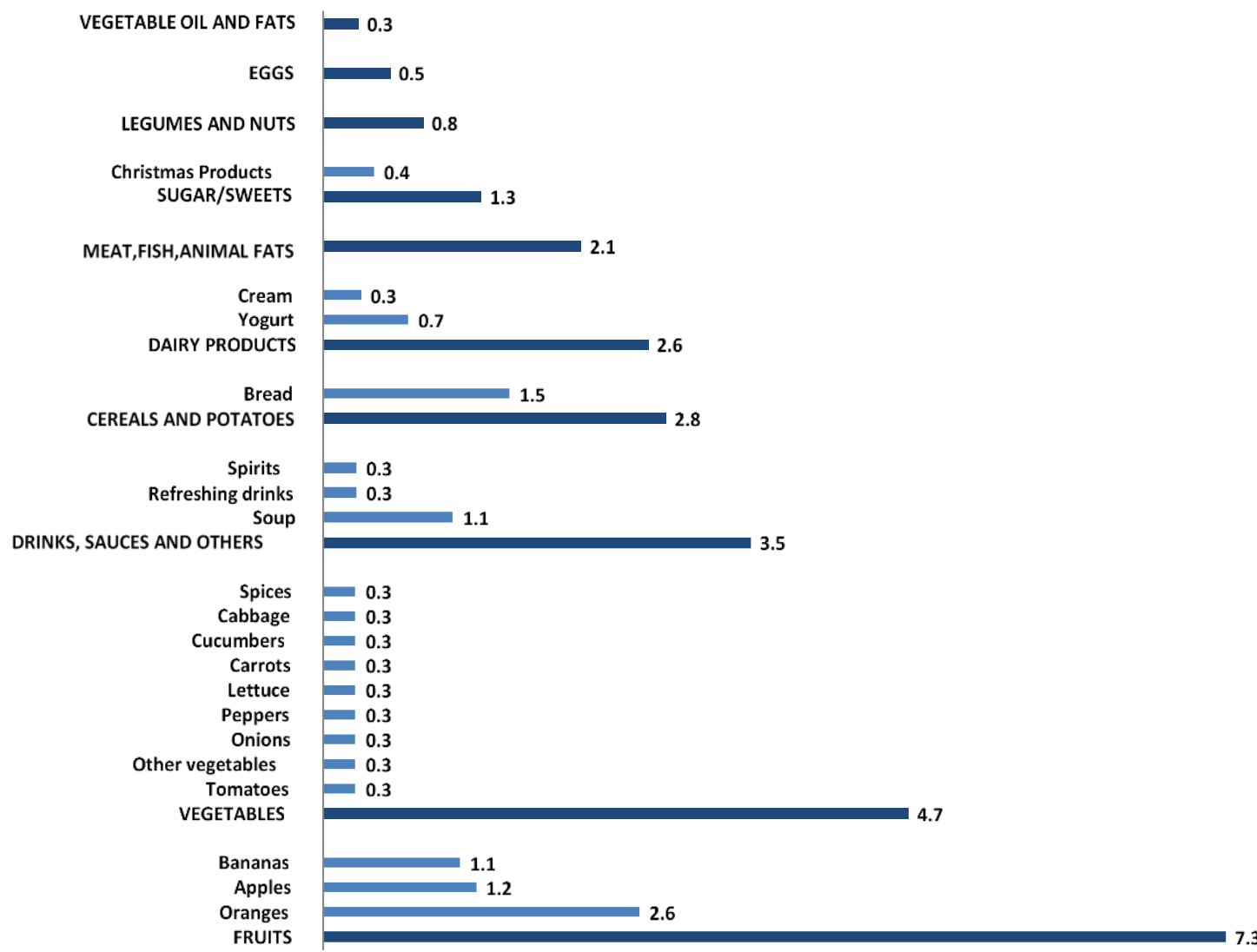

Figure 4-4. Annual waste (kg/person) for all food groups and main products in Spanish households (October 2014 - September 2015). Source: own elaboration. 
Food waste nutritional analysis: nutrients waste

Results of the food waste nutritional analysis, (i.e., the nutrients waste due to food waste), for energy, fiber, macro and micronutrients per capita year (cy), is shown in Table 4.3.

Table 4.3. Food waste nutritional analysis: energy (Kcal), proteins, fats, carbohydrates, fiber (all in g), minerals, and vitamins (mg) per capita per day (cy) wasted because of annual Spanish household's food waste (October2014-September 2015).

\begin{tabular}{lccccccc}
\hline & \multicolumn{7}{c}{ NUTRIENTS WASTE PER CAPITA YEAR (CY) } \\
\hline & $\begin{array}{c}\text { Energy } \\
(\text { Kcal) }\end{array}$ & $\begin{array}{c}\text { Proteins } \\
(\mathrm{g})\end{array}$ & $\begin{array}{c}\text { Fats } \\
(\mathrm{g})\end{array}$ & $\begin{array}{c}\text { Carbohydrates } \\
\text { (g) }\end{array}$ & $\begin{array}{c}\text { Fiber } \\
\text { ( })\end{array}$ & $\begin{array}{c}\text { Minerals } \\
(\mathrm{mg})\end{array}$ & $\begin{array}{c}\text { Vitamins } \\
(\mathrm{mg})\end{array}$ \\
Cereals and potatoes & 8013 & 212 & 28 & 1696 & 61 & 19563 & 127 \\
Dairy products & 4532 & 159 & 351 & 182 & 0 & 20042 & 69 \\
Drinks, sauces and others & 5433 & 228 & 323 & 205 & 0 & 13170 & 334 \\
Eggs & 802 & 67 & 59 & 0 & 0 & 2900 & 31 \\
Fruits & 3900 & 53 & 6 & 832 & 149 & 19936 & 2098 \\
Legumes and nuts & 2576 & 146 & 95 & 234 & 102 & 9563 & 116 \\
Meat, fish and animal fats & 4624 & 418 & 324 & 8 & 0 & 19354 & 181 \\
Oil and vegetable fats & 2392 & 0 & 266 & 1 & 0 & 497 & 46 \\
Sugar and sweets & 5128 & 80 & 232 & 666 & 35 & 4810 & 1964 \\
Vegetables & 2985 & 108 & 91 & 368 & 136 & 30793 & 14139 \\
\multicolumn{1}{c}{ TotAL } & 40385 & 1471 & 1777 & 4191 & 483 & 140627 & 19108 \\
\hline
\end{tabular}

As shown, as an average, because of annual food waste in Spanish households, the nutrients wasted per capita per year were 40,385 kcal, almost $7.5 \mathrm{~kg}$ of macronutrients (proteins, fats and carbohydrates), 483 grams of fiber and almost 160 grams of micronutrients (vitamins and minerals).

The food groups with more energy wasted were animal origin ones; together, meat, fish and animal fats and dairy products, accounted for the $22 \%$ of the total kcal wasted (11\% each one) with around $9150 \mathrm{kcal} / \mathrm{cy}$ wasted. This is because the big share that these groups accounted for the final proteins (39\% of the total, and only the group of meats accounted for the $28 \%$ ), and fats (38\% of the total). On the other hand, these groups did not accounted a significant share for total carbohydrates (only 4\%), being cereals and potatoes, and fruits the groups that accounted the most (40\% and $20 \%$ respectively of the total). 
For fiber, the food groups that accounted the most were fruits, with $31 \%$ of the total, and vegetables, $28 \%$. Moreover, once more, the groups of meats and dairy products together accounted the most for the final grams of minerals wasted in Spanish households (28\%, $14 \%$ each), together with vegetables (22\%). Finally, for vitamins, with the $74 \%$ of the total wasted per year, the food group of vegetables.

\section{Imported water and origin of food products}

The total amount of water imported from third countries for household food consumption in Spain over a one-year period was around $21,544 \mathrm{hm}^{3}$ (million $\mathrm{m}^{3}$ ). Figure 4.5 shows the origin of the imported water for the green (a), blue (b), grey (c) and total WF (d). The countries that annually accounted for most imported green water (19232 $\left.\mathrm{hm}^{3}, 41 \%\right)$ were Tunisia $\left(2,743 \mathrm{hm}^{3}\right)$, Portugal $\left(1,979 \mathrm{hm}^{3}\right)$, France $\left(1,181 \mathrm{hm}^{3}\right)$, Ivory Coast $\left(1,113 \mathrm{hm}^{3}\right)$ and Brazil $\left(939 \mathrm{hm}^{3}\right)$. With regard to imported blue water $\left(1,170 \mathrm{hm}^{3}\right)$, the five top-ranking countries alone accounted for $57 \%$ of the total: Portugal $\left(347 \mathrm{hm}^{3}\right)$, Tunisia $\left(101 \mathrm{hm}^{3}\right)$, Morocco $\left(77 \mathrm{hm}^{3}\right)$, France $\left(76 \mathrm{hm}^{3}\right)$ and Pakistan $\left(68 \mathrm{hm}^{3}\right)$. For the grey component $\left(1141 \mathrm{hm}^{3}\right)$ : United States $\left(223 \mathrm{hm}^{3}\right)$, Germany $\left(187 \mathrm{hm}^{3}\right)$, France $\left(146 \mathrm{hm}^{3}\right)$, Portugal $\left(77 \mathrm{hm}^{3}\right)$, and Canada $\left(34 \mathrm{hm}^{3}\right)$.

Figure 4.5.d shows the aggregated figures. Just five countries (Tunisia, Portugal, France, Ivory Coast and Brazil) accounted for nearly $41 \%$ of total imported water. Total imported green water accounted for almost all-total imported water (89\%), whereas both blue and grey water each had a share of around only $5.5 \%$ of the total amount.

According to the continent and subcontinent analysis, $28 \%$ of total imported water $(5,431$ $\mathrm{hm}^{3} /$ year) comes from Western Europe. This was followed by North Africa and the Near East, with $3,088 \mathrm{hm}^{3}$, equivalent to nearly $16 \%$.

Table 4.4 reports the imported water embedded in Spanish household food waste broken down by sub-continents. For the analyzed period, $848 \mathrm{hm}^{3}$ of imported water was wasted. This means that, according to Spanish household consumption patterns, a total of $4 \%$ of the total water imported $\left(21,544 \mathrm{hm}^{3}\right)$ was squandered. Imported green water with respect to food waste, the five main countries (that accounted for the $37 \%$ ) ranked by share were: Portugal $\left(67 \mathrm{hm}^{3}\right)$, France $\left(60 \mathrm{hm}^{3}\right)$, Vietnam $\left(53 \mathrm{hm}^{3}\right)$, Brazil $\left(50 \mathrm{hm}^{3}\right)$ and Germany $\left(28.5 \mathrm{hm}^{3}\right)$. For the blue component, the five countries that accounted for the largest share (59\%) of the total were Portugal $\left(16 \mathrm{hm}^{3}\right)$, Morocco $\left(9 \mathrm{hm}^{3}\right)$, France $\left(5 \mathrm{hm}^{3}\right)$, Pakistan $\left(4 \mathrm{hm}^{3}\right)$ and Peru $\left(3 \mathrm{hm}^{3}\right)$.

Finally, the five, similarly ranked, countries accounting for a major share of the final wasted imported grey water (61\%) were: United States $\left(27 \mathrm{hm}^{3}\right)$, Germany, Portugal, and France with $6 \mathrm{hm}^{3}$ each, and, finally, Canada with $4 \mathrm{hm}^{3}$. Like imported water for food consumption, imported green water with respect to food waste accounted for most of the total (83\%). 


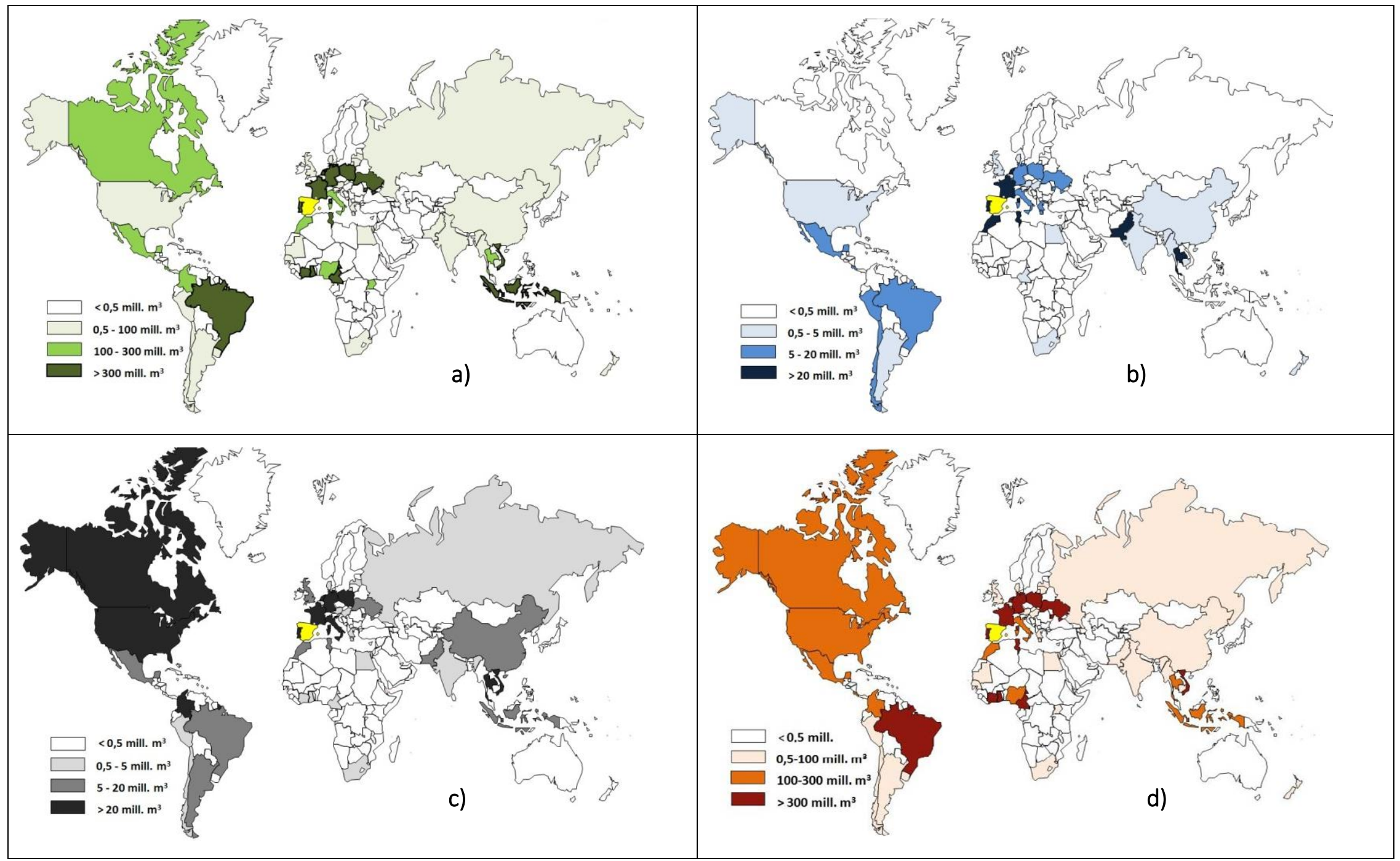

Figure 4-5. Annual imported water (million cubic meters; 1 mill. $\mathrm{m}^{3}=1 \mathrm{hm}^{3}$ ) with respect to Spanish household food consumption (October 2014 -September 2015) broken down by a) green, b) blue, c) grey and d) total virtual water. Source: own elaboration. 
Table 4.4. Annual imported virtual water (mill. $\mathrm{m}^{3}=1 \mathrm{hm}^{3}$ ) by origin with respect to food waste in Spanish households, (Oct. 2014 - Sept. 2015)

\begin{tabular}{lcccc}
\hline \multicolumn{5}{c}{ Total wasted IVW $\left(\mathrm{hm}^{3}\right)$} \\
\hline & Green VW & Blue VW & Grey VW & Total VW \\
North Africa and Near East & 26 & 10 & 2 & 38 \\
Sub-Saharan Africa & 32 & 2 & 0 & 34 \\
North America & 35 & 1 & 33 & 69 \\
South and Central America & 89 & 6 & 5 & 100 \\
Asia & 85 & 7 & 9 & 101 \\
Eastern Europe & 17 & 0 & 1 & 19 \\
Western Europe & 198 & 25 & 23 & 245 \\
Oceania & 1 & 0 & 0 & 1 \\
Rest & 220 & 11 & 10 & 242 \\
Overall total & 704 & 62 & 83 & 848
\end{tabular}

\section{Consumption and food waste water footprint}

The total annual WF of Spanish households, taking into account imported food products (and therefore imported water), was, on average, 1,205 $\mathrm{m}^{3}$ per person, equivalent to 3,302 liters per capita day (liters/cd). In absolute terms, the WF of Spanish household food consumption was $52,933 \mathrm{hm}^{3}$. Of the total WF per person over a one-year period, the green fraction accounted for around $77 \%$; $932 \mathrm{~m}^{3} /$ capita year $\left(\mathrm{m}^{3} / \mathrm{cy}\right)$, the blue for $12 \%\left(146 \mathrm{~m}^{3} / \mathrm{cy}\right)$ and the grey for $11 \%\left(127 \mathrm{~m}^{3} / \mathrm{cy}\right)$.

These results are plotted in Figure 4-6, showing the green, blue and grey WFs for food groups in Spanish annual household consumption. The food group that accounts for the largest share of the total (26\%), green (27\%), blue (21\%) and grey (26\%) WFs is meat, fish and animal fats. The second largest group for all consumption WFs -total (21\%), green (27\%), blue (21\%) and grey (26\%) - is dairy products. The groups with the smallest shares in all consumption WFs are eggs, vegetables, and legumes and nuts. In terms of the blue $W F$, the group sugar-sweets ( $3 \mathrm{~m}^{3} / \mathrm{cy}, 2 \%$ ) again had a smaller share, whereas vegetable oil and fats was the group that had the smallest share of the grey WF ( $3 \mathrm{~m}^{3} / \mathrm{cy}, 2 \%$ ).

These results are consistent with the individual product analysis. The top ten ranked products (out of 199) with respect to total consumption WF accounted for $53 \%$. Besides, the 20 products with the highest total consumption WF values accounted for up to $71 \%$. Olive oil is the product with largest total WF (143 $\left.\mathrm{m}^{3} / \mathrm{cy}, 12 \%\right)$. Of these 10 products, meat, fish and animal fats were: beef $\left(78 \mathrm{~m}^{3} / \mathrm{cy}, 6 \%\right)$, pork $\left(57 \mathrm{~m}^{3} / \mathrm{cy}, 5 \%\right)$ and chicken $\left(47.6 \mathrm{~m}^{3} / \mathrm{cy}, 4 \%\right)$; dairy products were: semi skimmed milk and milk (59 m³ $\mathrm{cy}, 5 \%$ each), cheese and skimmed milk (around $38 \mathrm{~m}^{3} / \mathrm{cy}, 3 \%$ each). 
These values were similar for the green WF, where only ten products accounted for the largest green WF (55\%). Again, olive oil (123 $\left.\mathrm{m}^{3} / \mathrm{cy}, 13 \%\right)$ and beef ( $\left.65.5 \mathrm{~m}^{3} / \mathrm{cy}, 7 \%\right)$ were the major products. The same applies for the blue WF, where only ten products accounted for the remaining 50\%, of which three were meat products - beef, pork and chicken - and another three dairy products - milk, semi-skimmed milk, and cheese-. Finally, for the grey WF, similar values were found for the top ten products (55\% of the total) and individual products (seven of which were from the meat or dairy products groups).

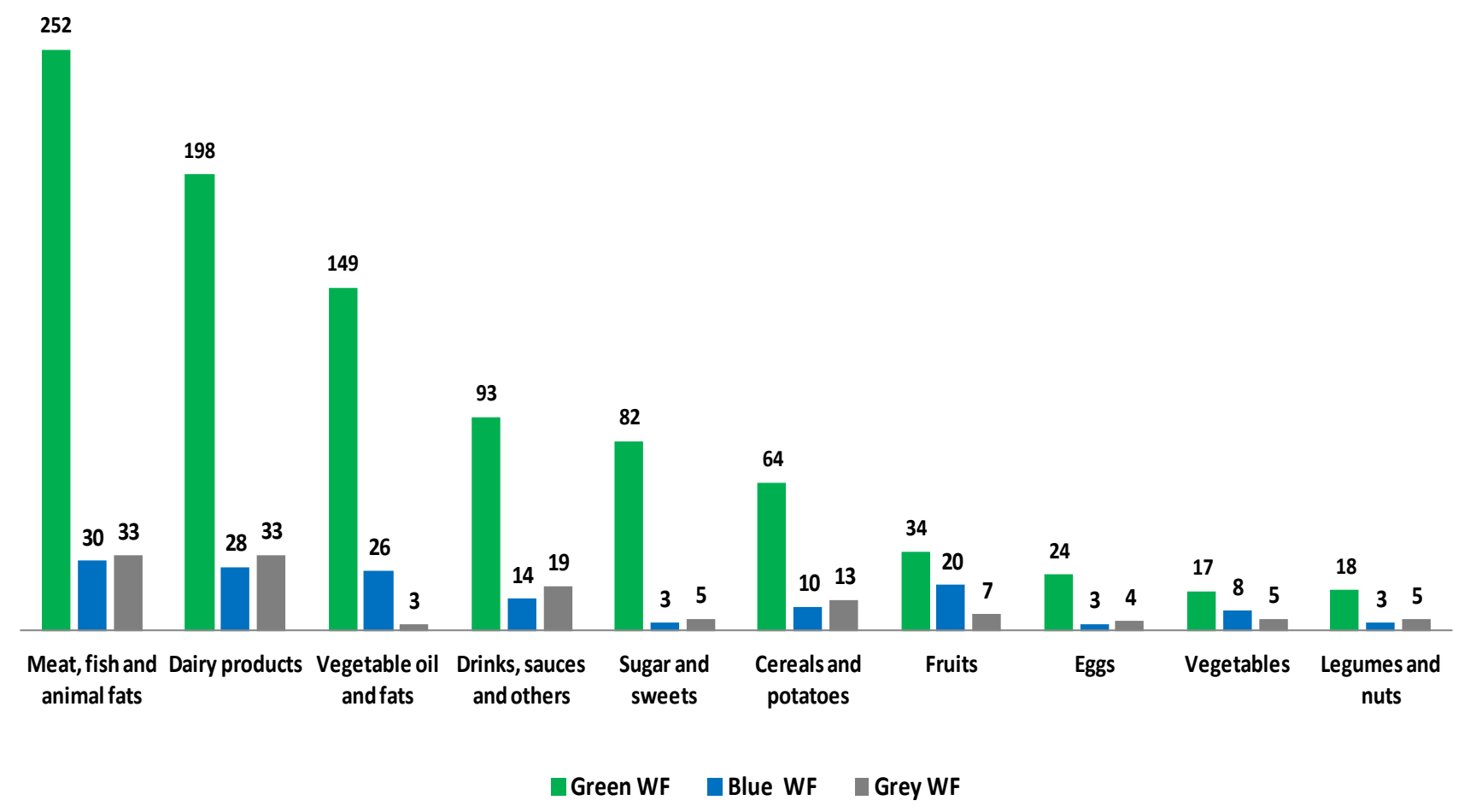

Figure 4-6 Annual (green, blue and grey) water footprint ( $\mathrm{m}^{3} /$ capita) for different Spanish household consumption food groups (October 2014 - September 2015). Source: own elaboration.

Figure 4-7 shows the results for Spanish household food waste WFs by food group for a one-year period. The total WF was $47.7 \mathrm{~m}^{3}$ per cy (4\% of the total food consumption WF). This is equivalent, on an annual basis, to an average water waste due to uneaten food of 131 liters/cd and $2095 \mathrm{hm}^{3}$ across the whole country. The total green WF of food waste was $35.4 \mathrm{~m}^{3}$ per capita year (i.e. $1555 \mathrm{hm}^{3}$ nationwide, $74 \%$ ), while the blue WF $\left(6.7 \mathrm{~m}^{3}\right.$ / cy, 14\%, $292 \mathrm{hm}^{3}$ nationwide) and grey WF (5.6 m $\mathrm{cy}, 12 \%, 248 \mathrm{hm}^{3}$ nationwide) accounted for the remainder. As far as the analysis by food group is concerned, meat, fish and animal fats and dairy products groups again had the largest share of the total waste WF: $10 \mathrm{~m}^{3}$ per capita year (22\%), and $9 \mathrm{~m}^{3}$ per capita year (19\%), respectively. 
They were also the major groups for green WF and grey WF. This was at variance with the blue WF, where the fruits $\left(1.4 \mathrm{~m}^{3} / \mathrm{cy}, 21 \%\right)$ and vegetables $\left(1.2 \mathrm{~m}^{3} / \mathrm{cy}, 19 \%\right)$ groups accounted for a large share of water waste.

On the other hand, the sugar and sweets, vegetable oil and fats, and eggs groups had the smallest share of all WFs. With regard to the analysis by product, the 20 products with the biggest total WF for food waste accounted for $48 \%$, and the first 10 for only $30 \%$. In this case, the products with the largest total WF for food waste were: bread $\left(2.29 \mathrm{~m}^{3} /\right.$ cy), coffee $\left(2.14 \mathrm{~m}^{3} / \mathrm{cy}\right)$, cold meats $\left(1.50 \mathrm{~m}^{3} / \mathrm{cy}\right)$, sweet corn $\left(1.49 \mathrm{~m}^{3} / \mathrm{cy}\right)$ and yogurts $\left(1.29 \mathrm{~m}^{3} / \mathrm{cy}\right)$. As regards the green WF for food waste, the products with the largest WF were again coffee $\left(2 \mathrm{~m}^{3} / \mathrm{cy}\right)$, bread $\left(1.85 \mathrm{~m}^{3} / \mathrm{cy}\right)$, cold meats $\left(1.16 \mathrm{~m}^{3} / \mathrm{cy}\right)$ and yogurts (1 $\left.\mathrm{m}^{3} / \mathrm{cy}\right)$, although, in this case, the list included eggs $\left(0.92 \mathrm{~m}^{3} / \mathrm{cy}\right)$.

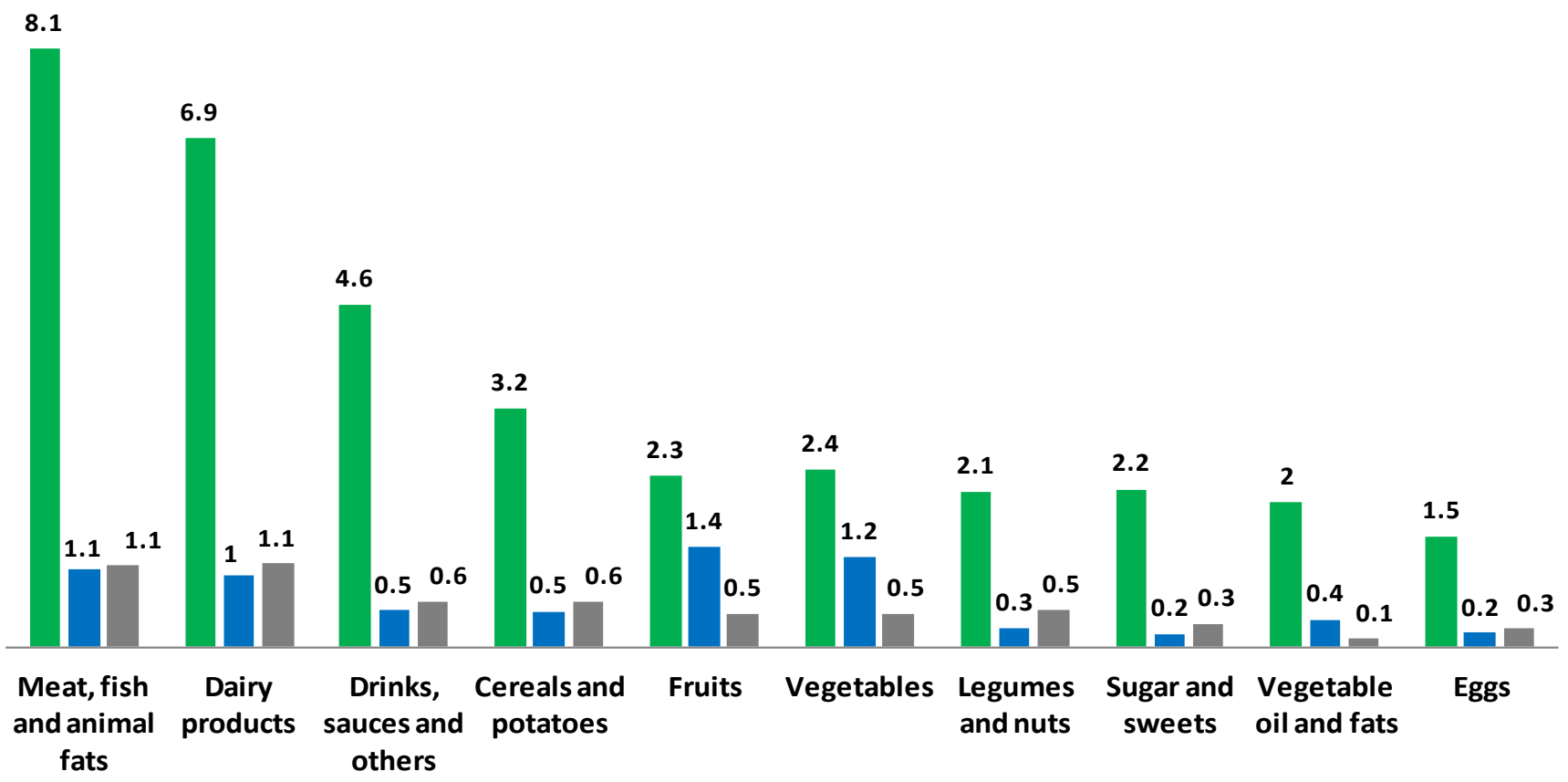

Green WF Blue WF $\square$ Grey WF

Figure 4-7. Annual (green, blue and grey) water footprint ( $\mathrm{m}^{3} /$ capita) for different food groups within Spanish household food waste (October 2014 - September 2015). Source: own elaboration.

Finally, with respect to the blue and grey WFs for food waste, the top-ranked 20 products accounted for $55 \%$ and $50 \%$, respectively. The most important products for the blue WF were: sweet corn $\left(0.68 \mathrm{~m}^{3} / \mathrm{cy}\right)$, oranges $\left(0.40 \mathrm{~m}^{3} / \mathrm{cy}\right)$, rice $\left(0.38 \mathrm{~m}^{3} / \mathrm{cy}\right)$, mayonnaise $(0.2$ $\left.\mathrm{m}^{3} / \mathrm{cy}\right)$ and apples $\left(0.19 \mathrm{~m}^{3} / \mathrm{cy}\right)$. The major products for the grey WF were: bread $(0.37$ $\left.\mathrm{m}^{3} / \mathrm{cy}\right)$, lentils $\left(0.3 \mathrm{~m}^{3} / \mathrm{cy}\right)$, cold meats $\left(0.17 \mathrm{~m}^{3} / \mathrm{cy}\right)$, yogurt $\left(0.16 \mathrm{~m}^{3} / \mathrm{cy}\right)$ and, finally, eggs $\left(0.16 \mathrm{~m}^{3} / \mathrm{cy}\right)$. 


\subsubsection{DISCUSSION}

\section{A) Consumption patterns}

\section{Food consumption}

The most consumed food products in a typical Spanish household are first and foremost drinks: bottled water and soft drinks, both accounting for $15 \%$ of total annual consumption (as shown in Figure 4-3). The consumption of bottled water has been expanding since 2015, reaching its maximum volume in 2016 (Ministerio de Agricultura Alimentación y Medio Ambiente, 2016a). Actual consumption in Spain during 2016 (including consumption outside the home) was 126 liters per capita, compared to the EU average of 112, and Spain ranked fifth among all member states with respect to bottled water consumption (EFBW, 2017). Moreover, Spain is the third largest consumer of soft drinks, second only to the UK and Germany (UNESDA, 2017).

The reason why water and soft drinks account for such a large part of household food consumption is that their consumption has a deep-rooted social and recreational component in Mediterranean countries, favored by the climate and communal leisure habits. Nevertheless, there has been a change in habits in recent years caused by the economic situation, with a drop in sales of bottled water and soft drinks at bars and restaurants and a slight increase in consumption within the household (ANFABRA, 2017).

Next on the list of most consumed food products are staple foods, like bread, milk (whole, semi-skimmed and skimmed milk accounts for the $11 \%$ of final consumption), fruit (oranges, bananas, apples, watermelon) and potatoes. Our calculations (Figure 4-3) showed that the consumption of livestock products (meat, animal fats and dairy products) equals the amount of consumed food from both the fruits and vegetables groups together.

This diverges from a recommended Mediterranean diet, in which fruit and vegetables, at the base of the pyramid (products to be consumed most often and that should sustain the diet), play a leading role (Bach-Faig et al., 2011a; Sáez-Almendros et al., 2013; Willett et al., 1995). In this traditional and recommended diet, two or more servings of fruits and vegetables should be eaten per meal every day (more than 20 servings per week), compared with meat (less than two servings per week), animal fats (less than one serving per week), and dairy products (at most two servings per day).

Moreover, our study found that food products like sugar and sweets, which, in the traditional Mediterranean diet, are positioned at the top of the food pyramid (foods to be eaten in moderate amounts and/or only on special occasions), are again consumed more than the sum of all legumes and nuts, and vegetable oil and fats together. These results are consistent with the idea that current Spanish consumption patterns, especially among the younger generations, are shifting towards a diet containing more meat and 
sugar products, as has been suggested by a number of studies for over a decade now (Bonaccio et al., 2012; Serra-Majem et al., 2004; Tur et al., 2004).

On the other hand, Spaniards today still consume more fruit and vegetables, and fewer livestock products than people in other Western countries do. Compared with our results, some authors reported higher values for animal (200\%-300\%) or sugar and sweets products (60\%-300\%), and lower values for fruit and vegetables (15\%-23\%) in countries such as: Austria (Vanham, 2013), USA (Pimentel and Pimentel, 2003) or North and Central Europe (Vanham et al., 2013a). Therefore, these results confirm that Mediterranean dietary habits and consumption persist, although changes have been observed over the last few years, and the consumption of more vegetables, fruit and fish should be encouraged (Tur et al., 2004).

\section{Food waste}

Some studies on different countries showed annual household food waste levels of 297 $\mathrm{kg}$ (Koester, 2013) and $212 \mathrm{~kg}$ (Jones, 2014) in the USA, $270 \mathrm{~kg}$ in the UK (WRAP, 2009), or $298 \mathrm{~kg}$ in Turkey (Pekcan et al., 2006). Gjerris and Gaiani (2013) reported household food waste values for the Nordic countries equivalent to $584 \mathrm{~kg}$ per year in Finland, 304 kg per year in Denmark, 204 kg per year in Norway and up to $120 \mathrm{~kg}$ per year in Sweden. In recent years, the UK's Waste and Resources Action Programme (WRAP) has denoted household food waste as being $260 \mathrm{~kg}$ per household per year, accounting for $19 \%$ of the final food purchases (Quested et al., 2012).

Total food waste in Spanish households over a one-year period was estimated as being 1.14 million tons nationwide. This amounts to $65.3 \mathrm{~kg}$ per household $(26 \mathrm{~kg} / \mathrm{cy}$ ). This means that only $4 \%$ of the total food consumed in Spanish households is wasted. These results are very different from the findings for the other countries listed above. However, a study carried out by the Spanish Ministry of Health, by means of weekly surveys of a sample of 413 Spanish households (HISPACOOP, 2012), reported similar results to ours, with an estimated food waste of $76 \mathrm{~kg}$ per household and year.

This would be equivalent in per capita terms to $32 \mathrm{~kg}$ per year. Likewise, the European Commission's final report on household food waste (Monier et al., 2011) -which is the only current reference at European level taking into account EUROSTAT statistics, national studies, and municipal waste data-, provided similar values for Spain (49 kg/ cy). This is below the EU27 average (76 kg/ cy) and the figure for Northern countries like the United Kingdom (137 kg/person-year), Germany (93 kg/person-year), Luxembourg (133 $\mathrm{kg} /$ person-year) or the Netherlands (113 kg/person-year). Nevertheless, values are lower for other Mediterranean and Eastern European countries like Portugal (36 kg/personyear), Slovakia (25 kg/person-year), Italy (46 kg/person-year) or Greece (37 kg/personyear). 
Possible explanations for the differing results are limitations with respect to data and methods and slightly different definitions of food waste used in different studies. Another plausible reason is that more food is wasted throughout the food supply chain and that Spanish consumers are less wasteful. However, social (e.g. community, cultural, consumption habits, or food behavior), economic (e.g. GDP, household income, or government programs), geographic (e.g. climate conditions and/or population) or environmental factors also account for such differences. Although some studies have been carried out over the last few years with respect to food waste behavior (Secondi et al., 2015; Stancu et al., 2016; Visschers et al., 2016), there still is little evidence regarding consumer perception and determinants with regard to food waste.

Waste reduction has been addressed by the EU over the past few years, and the European Parliament recommended practical measures to address and halve food waste by 2050 as part of the circular economy strategy (Mondéjar-Jiménez et al., 2016). Further research is thus required to assess food waste, by not only implementing common methodologies and definitions but also for understanding, which factors can influence consumer behavior.

\section{Nutrients waste}

As shown, because of annual food waste in Spanish households, the nutrients wasted per capita per year in average were 40,385 kcal, 7439 grams of macronutrients (proteins, fats, and carbohydrates), 483 grams of fiber and almost 160 grams of micronutrients (vitamins and minerals).

According to some studies, depending upon demographic and other sociocultural factors, the energy intake for a healthy diet requirement varies between 2,000 and 2,500 $\mathrm{kcal} /$ capita day (SIWI, 2015). This means that we waste around the $5 \%$ of the recommended daily energy intake. This implies that if food had not been wasted in the whole country, and due to the total loss of kcal that entails, there would have been energy requirements to feed almost 2.2 million people. Alternatively, even to feed a single person for 18 entire days.

The food groups that accounted more for the loss of energy were from animal origin; meats, fats and dairy products: $22 \%$ of total kcal wasted (while fruits and vegetables together accounted for the $17 \%$ of the total kcal wasted). This is mainly because the big share that this group accounted for the final waste of proteins (39\%, while only $11 \%$ of fruits and vegetables), and fats (38\% of the total, while only $5 \%$ of fruits and vegetables). These groups also contributed to almost $30 \%$ of total minerals wasted.

These results are in accordance with the ones of Alexander et al. (2017), where they concluded that the greatest rates of energy and proteins loss were associated with livestock production, and therefore, lessening animal origin products' consumption in diets can substantially affect the food system efficiency and its associated environmental 
impacts. These authors also reported that both consumer food waste and overconsumption add final losses of energy (10.3\%, 8.6\% without over-consumption) and protein ( $9 \%, 10.3 \%$ without over-consumption) in world food systems. Our results seem lower, and they can be explained, as described above, because of the lower food waste levels within Spanish households.

Similar results were reported by Kummu et al. (2012). They concluded that around 25\% of total food kcal (614 kcal/capita day) produced (estimated by these authors at 2609 $\mathrm{kcal} /$ capita day) are lost or wasted in all the food chain, i.e. from field to final household consumption. Within all losses in the food chain, the ones regarding consumers at home were $214 \mathrm{kcal} /$ capita day, meaning the $30 \%$ of total energy losses, and the $8 \%$ of the total energy supply. Ours results, on the other hand, were $111 \mathrm{kcal} /$ capita day, lower than the ones reported by Kummu et al. (2012). Again, possible answers are because possible more losses throughout the food supply chain (or Spanish consumers are less wasteful, as explained above).

Beretta et al. (2013) showed that the largest contribution to food losses occurred both in households and in processing stages, with $1 / 3$ of edible calories lost within the value chain, and, if not edible food parts were wasted, $50 \%$ more food calories could be available. More research has to be done in order to quantify better the edible and nonedible parts of the food waste, to make more clear conclusions about the associated nutrients lost.

\section{B) Water implications}

Food consumption and waste WF calculations are based on global WF datasets for crop and livestock products (Mekonnen and Hoekstra, 2011, 2012) to assure the use of the same data source for all 199 food products. Yet, previous studies in Spain have found that WF estimations can differ significantly using more disaggregated data (Garrido et al., 2010).

Moreover, some differences in WF calculations have been reported for agricultural products such as tomatoes (Chico et al., 2010), olives and olive oil (Salmoral et al., 2011) or pork (De Miguel et al., 2015) in Spain. Local climate variability and agricultural practices can have large effects on the WF for agricultural products.

The wide range of estimations for the same products and countries requires a detailed comparison of the values reported by Mekkonen and Hoekstra $(2011 ; 2012)$ and used in this research. There is, therefore, a need for more national studies and further research into the calculation of the WF of local products. 


\section{Food consumption}

Food imports account for $41 \%$ of the total WF of food consumption in Spanish households $\left(21,544 \mathrm{hm}^{3}\right)$. Our results are not consistent with other similar studies, where the total

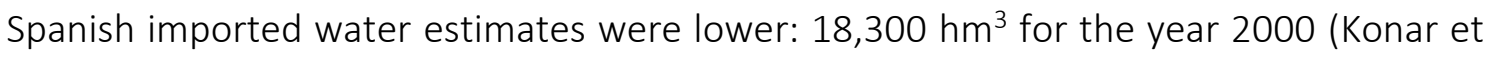
al., 2011). The high imported water ratio highlighted by some authors is proportional to the expansion of globalization and the rise of the global food trade. In fact, the water volume associated with the global food trade has doubled over the past two decades (Chapagain et al., 2006; Dalin et al., 2012). Besides, green water (89\%) has the largest share in total imported water. This is consistent with other studies (Hanasaki et al., 2010; Yang et al., 2006).

Of total imported water, $28 \%$ comes from Western Europe. Portugal, France, and Germany are three of the top-ranking six countries, accounting for $21 \%$ of the total. The data for water imported from Portugal and France in our study stand to reason, as they are both neighboring countries and major agricultural producers. The products that account for most of Portugal's values are olive and sunflower oils, whereas the main product for France is beef (39\% of the total water imported from France).

North Africa and the Middle East region rank second in terms of water imported to Spain. Moreover, Tunisia is the country with the highest values. A possible explanation is olive oil importation from Tunisia (although the import factor, $X_{p}$, of olive oil is only $16 \%$ ), amounting to nearly 87,000 tons per year ( $54 \%$ of total imports), as well as the high WF values of olive oil in Tunisia (42,080, 1554 and $177 \mathrm{~m}^{3} /$ ton for the green, blue and grey WFs, respectively). Brazil and the Ivory Coast are the other members of the top six countries with the highest values. Their prominence is mainly due to the fact that they export products not produced in Spain, that is, with an Xp factor of $100 \%$, such as coffee in Brazil, and cocoa and chocolate in Ivory Coast. The five products that accounted for most of this total imported water were olive oil (20\%), beef (16\%), coffee (12\%) and cocoa and chocolate (10\% each). The first two rank high because of their high WF values, whereas the next three are prominent because Spain depends entirely on imports of these products, i.e. there is no national production.

Spain relies significantly on imported VW from many large agricultural producers. The bulk of the imports are cereals and soya products used for animal feed (Garrido et al., 2010). In this respect, Spanish consumers contribute indirectly to exacerbating world water hotspots and unsustainable groundwater exploitation in many areas that have been associated with the growth of the VW trade (Biewald et al., 2014; Konar et al., 2016). As far as Spain is concerned, these effects are associated with the consumption of animal products. Therefore, cutting down meat consumption, and maintaining and promoting the healthier Mediterranean diet, as well as moderating food waste at the household level and across the entire value supply chain would reduce the negative effects of the VW trade. 
The WF of food consumption in Spanish households is 1,205 $\mathrm{m}^{3} / \mathrm{cy}$ (equal to 3302 liters/cd). The products that account for the largest share are products of animal origin: meat, animal fats and dairy products. Together, these two food groups account for nearly half of the total WF. On the other hand, the sum of the fruits, vegetables, and legumes and nuts food groups accounts for only $10 \%$ of the total. Although fruit, vegetables, and legumes and nuts consumption is similar to the amount of meat and dairy products consumed, there is a big difference between their WFs (463 $\left.\mathrm{m}^{3} / \mathrm{cy}\right)$. Therefore, these results are consistent with others suggesting that consumption patterns based on a vegetarian diet or a greater consumption of vegetables, fruit or legumes lead to larger water savings than eating habits based on the consumption of livestock products (Jalava et al., 2014; López-Gunn et al., 2012; Harold J Marlow et al., 2009; Pimentel and Pimentel, 2003; Reijnders and Soret, 2003; Tilman and Clark, 2014; Vanham et al., 2016a, 2016b, 2013b).

\section{Food waste}

Imported water with respect to Spanish household food waste from October 2014 to September 2015 was $848 \mathrm{hm}^{3}$. The largest volume of wasted water originates from Western Europe, where Portugal, France and Germany are three of the five countries from which most imported water is later wasted. In the case of Portugal, cream accounts for the largest share of wasted water ( $54 \mathrm{hm}^{3}, 62 \%$ of total wasted water for Portugal). Dairy products again account for the highest share for France: $70 \%$ of the total, around $50 \mathrm{hm}^{3}$.

The other two highest-ranking countries are Vietnam and Brazil, mainly due to imports of coffee, a product with an import factor of $100 \%$ and a waste factor of $11 \%$. Besides, coffee alone accounts for 34\% of total Spanish imported water waste: $291 \mathrm{hm}^{3}$. Other products of animal origin (beef, cream, and milk powder) also account for a large share (19\%). Many countries can save domestic water resources by importing water-intensive products (Chapagain et al., 2006). However, if these products are wasted and thrown away, water savings are uncertain.

Clearly, food waste implies the loss of water, that is, the water used to produce the food. Because Spanish households wasted 1.14 million tons of food over a one-year period, $2095 \mathrm{hm}^{3}$ of water was wasted. On average, one person wasted $47.7 \mathrm{~m}^{3}$ per year (131 liters/cd) of total WF.

This accounts for $4 \%$ of the total food consumption WF. These calculations are similar to the results reported by Kummu et al. (2012), who estimated the total food waste WF at $6 \%$. However, absolute values are at variance, as Kummu et al. (2012) reported global water waste caused by food waste as being approximately $27 \mathrm{~m}^{3}$ per capita year. Other studies reported that uneaten food (Hall et al., 2009; Lundqvist et al., 2008) accounted for from $25 \%$ to $50 \%$ of fresh water, albeit in respect of the entire food supply chain. 
Therefore, a comparison with our calculations is unlikely to be reliable and conclusive. In terms of products, although waste for the meat, fish and animal fats and dairy products groups was low, they were the groups with the largest food waste WF, at $19 \mathrm{~m}^{3}$ per capita year (41\%). These results are consistent with findings for the food consumption WF and are explained by the high WF values of livestock products. Livestock product WF values account for a larger share of the final food waste WF than the kilograms of these products that are wasted. However, fruits and vegetables have the largest share of blue WF of food waste (1.4 and $1.2 \mathrm{~m}^{3}$ per capita year respectively). Therefore, not only reducing livestock products consumption will reduce WF values, but also not wasting fruits and vegetables could lead also to major water savings.

Much more water can be saved by reducing food waste than by water-saving washing machines or flush toilets (Lundqvist et al., 2008). Therefore, the importance of saving freshwater by reducing food waste will be crucial for dealing with water scarcity problems in the coming decades.

As an illustrative example of our results, if Spanish households had not wasted any cream (with a blue WF for food waste of $0.09 \mathrm{~m}^{3} / \mathrm{cy}$ ), there would have been enough water to irrigate 82,000 tons of wheat, 52,000 tons of potatoes, 25,000 tons of oranges or even to produce 11,300 tons of new cream in Spain. In other words, $30 \mathrm{hm}^{3}$ would be available for other agricultural or industrial purposes. 


\subsection{A comparison of the Mediterranean Diet and Current Food Consumption PATTERNS IN SPAIN FROM A NUTRITIONAL AND WATER PERSPECTIVE}

\subsubsection{RESULTS}

\section{Diet's composition}

Figure 4-8 shows (a) the pyramid resulting from applying the recommended Med $\mathrm{Diet}_{\text {to }}$ Spanish households consumption, following the guidelines of the Mediterranean Diet Foundation and its research studies (Bach-Faig et al., 2011a), and (b), their current food consumption. The base of MedDiet pyramid includes two food groups: "Fruits and Vegetables" and "Cereals, Olive oil and Healthy drinks" (representing 41 and 31\% of the total diet consumption respectively). In contrast, at the top of the pyramid the products less consumed; "Red or processed meat" representing $1 \%$ of the total consumption, and "Sugar, sweets, sauces and beverages", representing only $0.75 \%$.

In the Spanish households' current consumption, "fruits and vegetables" only represent $26 \%$ of the total diet consumption, $171 \mathrm{~kg}$ per capita per year consumed (kg/cy), $100 \mathrm{~kg}$ less than in Med Diet. Moreover, the group of "Cereals, Olive Oil and healthy drinks" only represented the $22 \%$ of the total Current Diet $(143.5 \mathrm{~kg} / \mathrm{cy}, 60 \mathrm{~kg}$ less than in Med Diet). "Olives, nuts, seeds, and condiments" group was also much less consumed in Current Diet in comparison with MedDiet; more than three times lower, with only $17 \mathrm{~kg} / \mathrm{cy}$ (2.6\%) compared to the recommended $61 \mathrm{~kg} / \mathrm{cy}$ (9\%). Other food groups with lower

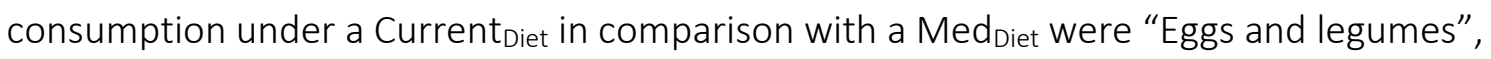
from 23 (3.5\%) in Med Diet to $16 \mathrm{~kg} / \mathrm{cy}(2.5 \%)$ in Current Diet. $_{\text {. }}$

The greater 'disproportion' of the food pyramids is due to the higher consumption of "Dairy products", "Sugar, sweets, sauces and beverages" and "Red and/or processed meat" food groups in Current Diet $_{\text {in comparison with Med }}$ Diet. Particularly important was the increase in "Sugar, sweets, sauces and beverages" consumption; 86 kg more per person per year (from 5 to 91) in comparison with Med $_{\text {Diet. }}$ This group represented only

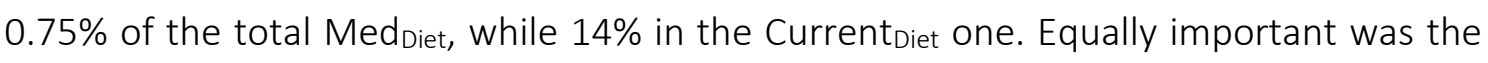
increase in the dairy products consumption from a recommended intake of $54 \mathrm{~kg} / \mathrm{cy}(8 \%)$ to $104 \mathrm{~kg} / \mathrm{cy}(16 \%)$ in Current diet. Moreover, some other groups have also higher consumption levels comparing CurrentDiet with MedDiet, as "Red and processed meat", going from 7 (1\%) to 32 (5\%) kg/cy, and "Potatoes", from 9 (1.5\%) to $29(4.5 \%) \mathrm{kg} / \mathrm{cy}$. Finally, "White meat and vegetable fats" group consumption also increased with a Current $_{\text {Diet, }}$ from $9(1.3 \%)$ to $23(3.5 \%) \mathrm{kg} / \mathrm{cy}$. 


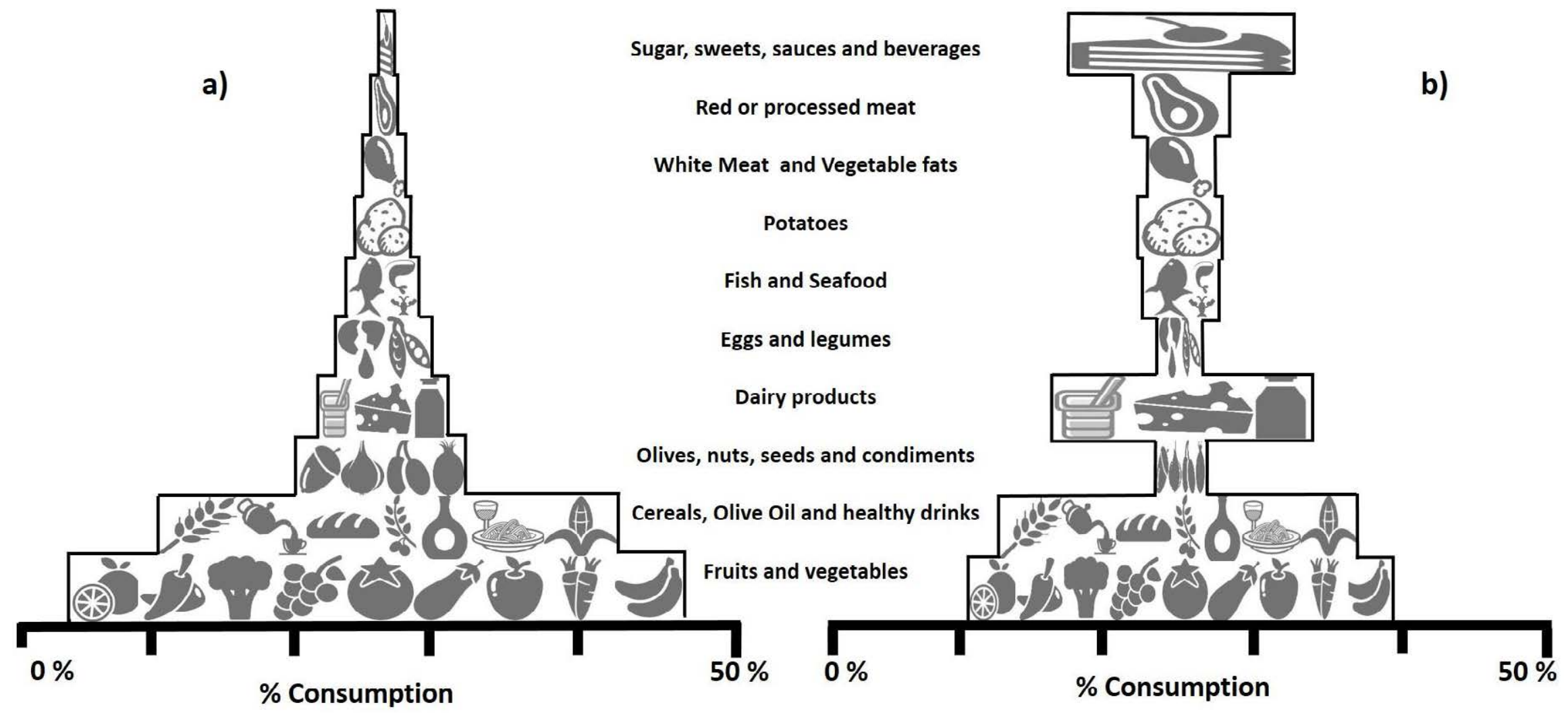

Figure 4-8. Diets composition divided into 10 food groups and their percentage of final consumption in Spanish households for a) estimated Mediterranean diet and b) current food consumption. Source: own elaboration. 


\section{Nutritional Analysis}

Multidimensional nutritional analyses of both Current $t_{\text {Diet }}$ and Med Diet $_{\text {are summarized in }}$ Table 4.5, calculated for each component (energy, proteins, fats, carbohydrates, fiber, water, minerals, and vitamins) for every food group (as well as their consumption in grams), per capita day (cd). This summarizes only the intake of food domestically, and overall represents $75 \%$ of the total consumption (as described in Section 2.3). It can be

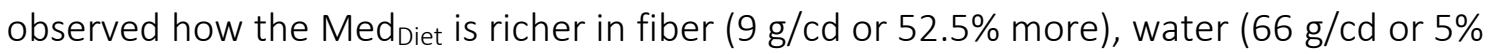
more), minerals ( $2988 \mathrm{mg} / \mathrm{cd}$ or $33.5 \%$ more) and vitamins (338 mg/cd or $70 \%$ more).

However, Mediterranean Diet has lower levels of energy (321 kcal/cd or $15 \%$ less), proteins ( $27 \mathrm{~g} / \mathrm{cd}$ or $32 \%$ less) and fats ( $27.5 \mathrm{~g} / \mathrm{cd}$ or $27 \%$ less) compared to the Current Diet. The only nutritional component that remains relatively the same in both diets is carbohydrates, although it is slightly higher in the MedDiet (almost $2 \mathrm{~g} / \mathrm{cd}$ or $1 \%$ more). Looking at each nutritional component, MedDiet has lower calories because of lower intakes of meats (white and red) and "Sugar, sweets, sauces and beverages" food groups. These three groups together accounted for $37 \%$ of the total kcal in Current $\mathrm{kcal} / \mathrm{cd})$, but only $8 \%$ in Med Diet $(138 \mathrm{kcal} / \mathrm{cd})$.

In addition, "Cereals, olive oil and healthy drinks" and "Fruits and Vegetables" food groups together contributed the most to the total kcal $(67 \%, 1237 \mathrm{kcal} / \mathrm{cd})$ in Med Diet. Animal's origin groups (dairy products and red/white meat), together with the sugar and sweets one, are also the main cause for higher proteins and fats levels in Current $t_{\text {Diet }}$ in comparison with Med Diet. $_{\text {In }}$ the case of proteins, these four groups contributed $48 \mathrm{~g} / \mathrm{cd}$

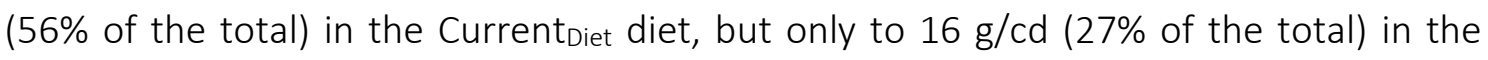
Mediterranean Diet.

Regarding fats, these four groups contributed to the total Current ${ }_{\text {Diet }} 66 \mathrm{~g} / \mathrm{cd}$ ( $64 \%$ of the

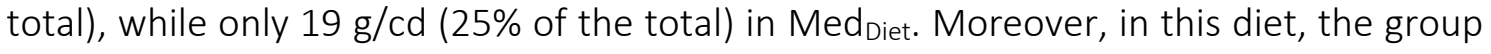
of "sugar and sweets" accounted for 17 times fewer fats than CurrentDiet. Within the group of fats, MedDiet has mainly half of the cholesterol levels than Current $t_{\text {Diet }}$ (39 and 76 $\mathrm{mg} / \mathrm{cd}$ respectively). Again, the main differences are rooted in the animal's origin and in

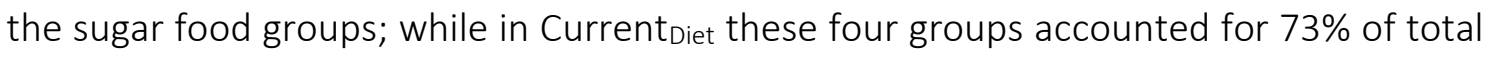
cholesterol levels (55 g/cd) in MedDiet only 41\% (16 g/cd).

On the other hand, higher values in MedDiet for fiber, water, minerals and vitamins were observed mainly because of higher consumption of "Fruits and vegetables", "Cereals, olive oil and healthy beverages" and "Olives, nuts, seeds and condiments" groups. Regarding fiber, "Fruits and vegetables" moved from 8 in Current Diet $_{\text {to }} 13 \mathrm{~g} / \mathrm{cd}$ in Med Diet. While "Olives, nuts, seeds and condiments" were five times higher in Med Diet: from 1 to $5 \mathrm{~g} / \mathrm{cd}$. 
Table 4.5. Multidimensional nutritional analyses (energy, proteins, fats, carbohydrates, fiber, water, minerals, and vitamins) and consumption for every food group of Current Consumption and Mediterranean Diet, in nutritional values per capita per day

\begin{tabular}{|c|c|c|c|c|c|c|c|c|c|}
\hline \multicolumn{10}{|c|}{ CURRENT CONSUMPTION (CAP DAY) } \\
\hline & $\begin{array}{l}\text { Consumption } \\
\text { (g) }\end{array}$ & $\begin{array}{l}\text { Energy } \\
\text { (Kcal) }\end{array}$ & $\begin{array}{l}\text { Proteins } \\
\text { (g) }\end{array}$ & $\begin{array}{l}\text { Fats } \\
\text { (g) }\end{array}$ & $\begin{array}{c}\text { Carbohydrates } \\
\text { (g) }\end{array}$ & $\begin{array}{l}\text { Fiber } \\
\text { (g) }\end{array}$ & $\begin{array}{l}\text { Water } \\
\text { (g) }\end{array}$ & $\begin{array}{l}\text { Minerals } \\
(\mathrm{mg})\end{array}$ & $\begin{array}{l}\text { Vitamins } \\
\text { (mg) }\end{array}$ \\
\hline Sugar, sweets, sauces and beverages & 249 & 382 & 4 & 17 & 53 & 1 & 143 & 428 & 135 \\
\hline Read or processed meat & 89 & 231 & 18 & 17 & 1 & 0 & 52 & 946 & 8 \\
\hline White Meat and Vegetable fats & 64 & 187 & 11 & 16 & 0 & 0 & 37 & 294 & 10 \\
\hline Potatoes & 81 & 71 & 2 & 0 & 15 & 2 & 63 & 536 & 16 \\
\hline Fish and Seafood & 73 & 85 & 13 & 3 & 0 & 0 & 57 & 480 & 8 \\
\hline Eggs and legumes & 44 & 64 & 5 & 3 & 4 & 2 & 31 & 282 & 5 \\
\hline Dairy products & 285 & 257 & 15 & 16 & 14 & 0 & 240 & 1768 & 8 \\
\hline Olives, nuts, seeds and condiments & 46 & 55 & 1 & 4 & 4 & 1 & 33 & 1703 & 161 \\
\hline Cereals, Olive Oil and healthy drinks & 393 & 655 & 11 & 25 & 88 & 3 & 266 & 1068 & 6 \\
\hline Fruits and vegetables & 470 & 195 & 5 & 2 & 37 & 8 & 419 & 1389 & 128 \\
\hline Total & 1794 & 2182 & 84 & 102 & 215 & 17 & 1340 & 8894 & 485 \\
\hline \multicolumn{10}{|c|}{ MEDITERRANEAN DIET (CAP DAY) } \\
\hline & $\begin{array}{c}\text { Consumption } \\
\text { (g) }\end{array}$ & $\begin{array}{l}\text { Energy } \\
\text { (Kcal) }\end{array}$ & $\begin{array}{l}\text { Proteins } \\
\text { (g) }\end{array}$ & $\begin{array}{l}\text { Fats } \\
\text { (g) }\end{array}$ & $\begin{array}{l}\text { Carbohydrates } \\
\text { (g) }\end{array}$ & $\begin{array}{l}\text { Fiber } \\
\text { (g) }\end{array}$ & $\begin{array}{l}\text { Water } \\
\text { (g) }\end{array}$ & $\begin{array}{l}\text { Minerals } \\
\text { (mg) }\end{array}$ & $\begin{array}{l}\text { Vitamins } \\
\text { (mg) }\end{array}$ \\
\hline Sugar, sweets, sauces and beverages & 13 & 20 & 0 & 1 & 3 & 0 & 8 & 23 & 7 \\
\hline Read or processed meat & 19 & 48 & 4 & 4 & 0 & 0 & 11 & 199 & 2 \\
\hline White Meat and Vegetable fats & 24 & 70 & 4 & 6 & 0 & 0 & 14 & 110 & 4 \\
\hline Potatoes & 27 & 23 & 1 & 0 & 5 & 1 & 21 & 176 & 5 \\
\hline Fish and Seafood & 32 & 37 & 6 & 2 & 0 & 0 & 25 & 209 & 3 \\
\hline Eggs and legumes & 64 & 92 & 7 & 4 & 6 & 3 & 44 & 406 & 8 \\
\hline Dairy products & 149 & 134 & 8 & 8 & 7 & 0 & 125 & 922 & 4 \\
\hline Olives, nuts, seeds and condiments & 167 & 198 & 5 & 13 & 13 & 5 & 119 & 6129 & 579 \\
\hline Cereals, Olive Oil and healthy drinks & 557 & 928 & 16 & 35 & 125 & 4 & 377 & 1514 & 8 \\
\hline Fruits and vegetables & 743 & 309 & 7 & 3 & 58 & 13 & 662 & 2195 & 203 \\
\hline Total & 1794 & 1860 & 58 & 75 & 217 & 26 & 1406 & 11882 & 823 \\
\hline
\end{tabular}


In relation to water consumption, it was observed how the values of these three mentioned groups went from $718 \mathrm{~g} / \mathrm{cd}$ (53\% of the total diet) in Current $t_{\text {Diet }}$ to $1158 \mathrm{~g} / \mathrm{cd}$ $(82 \%)$ in the MD. Likewise, a similar situation can be seen with minerals and vitamins. Regarding minerals, the three groups together went from 4160 to $9339 \mathrm{mg} / \mathrm{cd}$ from a Current $_{\text {Diet }}$ diet to a Med Diet one (accounting respectively $47 \%$ and $83 \%$ of the total). In the case of vitamins, these groups had $295 \mathrm{mg} / \mathrm{cd}$ in a Current Diet diet (60\% of the total)

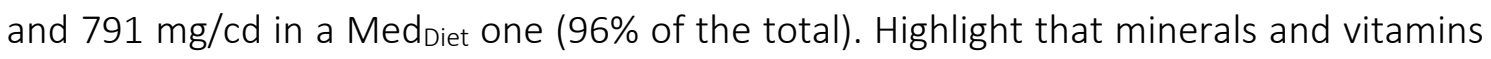
levels of the "Sugar, sweets, sauces and beverages" were 18-19 times lower in Med Diet.

\section{Water Footprint (WF)}

Figure 4-9 shows the Water Footprint of CurrentDiet compared to the MedDiet. As can be seen, the WF of Current $t_{\text {Diet }}$ was higher in all its components (green, blue, and grey). Especially large is the difference in Green WF between both diets: while in Current Diet $_{\text {Was }}$

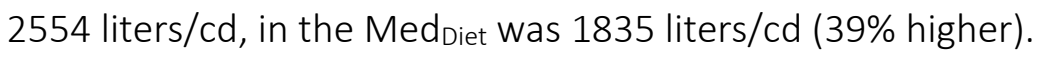

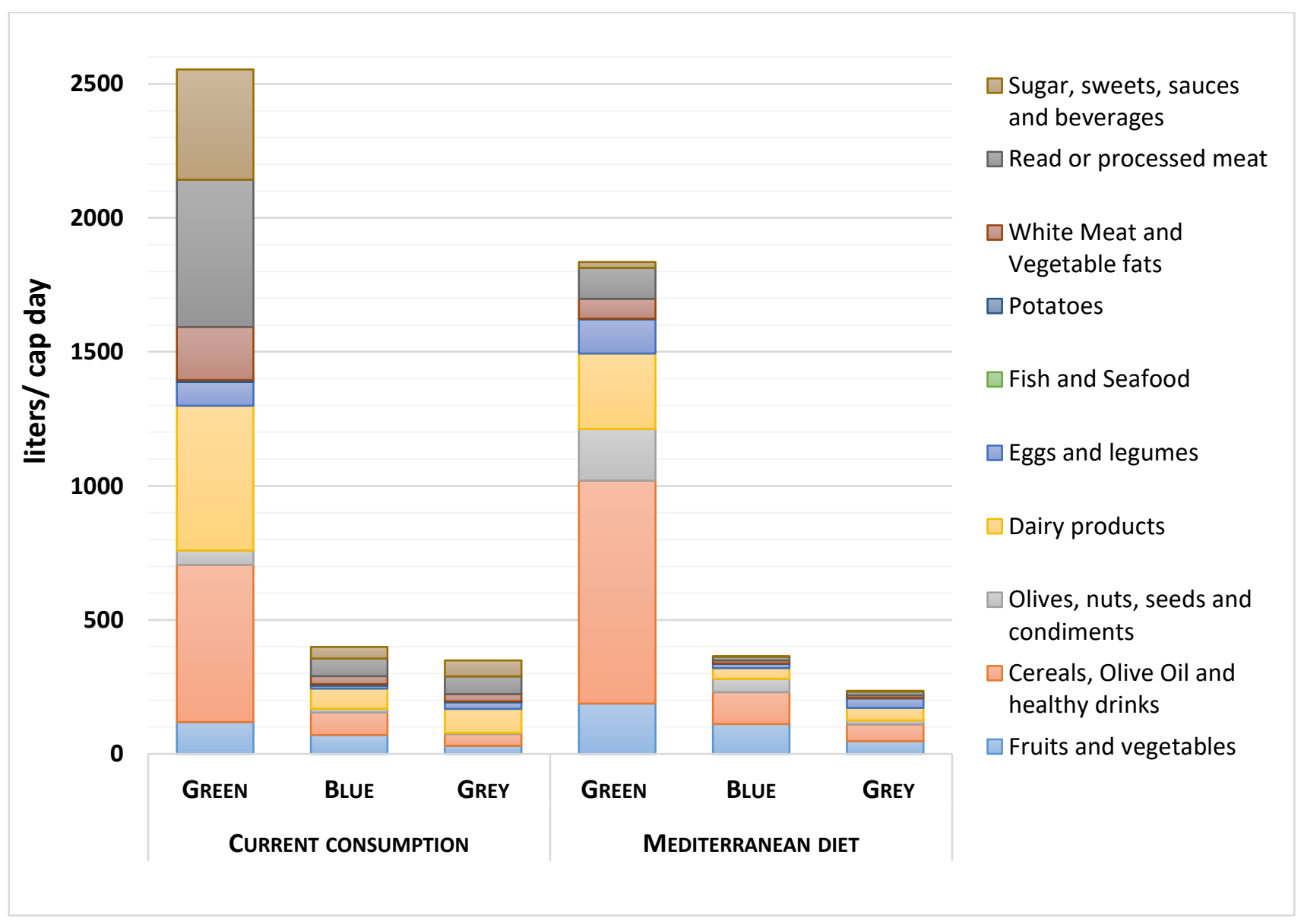

Figure 4-9. Water footprint (liters/capita day) divided per component (Green, Blue and Grey) of Spanish household's current consumption and Mediterranean Diet. Source: own elaboration. 
This difference was mainly due to larger green WF in CurrentDiet of "Red or processed meats" (434 liters/cd higher than MedDiet), "Sugar, sweets, sauces, and beverages" (389 liters/cd higher than Med Diet), and "Dairy Products" (258 liters/cd higher than MedDiet).

Differences with Blue WF between both diets were lower. CurrentDiet used 34 liters of blue water more per person day than the MedDiet one, (399 to 365 liters/cd respectively, $9 \%$ higher). The largest differences were found in the groups of "Sugar, sweets, sauces,

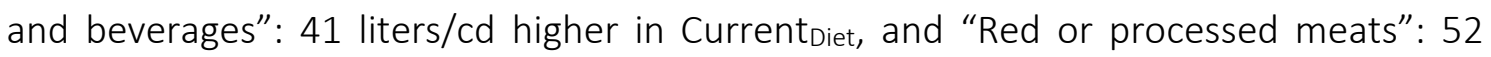

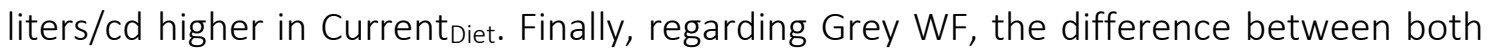
diets was 113 liters/cd more with a Current Diet $_{\text {diet than with a Med }}$ Diet one (48\% higher). Similarly to the other WF components, food groups of "Dairy products", "Sugar, sweets, sauces, and beverages" and "Red or processed meats" made the biggest differences (43, 56 and $52 \mathrm{l} / \mathrm{cd}$ respectively higher in Current Diet $_{\text {than }}$ in Med $_{\text {Diet }}$ ).

The analysis of the Total WF indicates that following a Mediterranean diet in Spanish

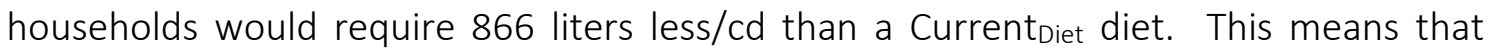
within a year, the Total WF per person would be $316 \mathrm{~m}^{3}$ lower consuming a Med Diet. Looking exclusively at the consumptive use of water (Green + Blue WF), the WF will be 753 liters per capita day less ( $275 \mathrm{~m}^{3}$ per year) with MedDiet than with a Current Diet. $_{\text {. }}$.

\section{Nutritional Water Productivity (NWP)}

Figure 4-10 shows the results of the NWP analysis for Blue and Green (consumptive use) water in both diets. As can be seen, in all eight nutritional components, Med Diet was more nutritionally-water efficient than Current $t_{\text {Diet }}$ (for both green and blue). The results show that in Green NWP, the Med Diet was highly efficient in vitamins (123\% higher), followed by fiber, minerals and water (56, 55.5 and $52 \%$ respectively higher). Moreover, the Med $_{\text {Diet }}$ was very efficient also in energy, proteins and carbohydrates water productivity values (around 39\% higher in all of them with respect to the Current Diet$_{\text {) }}$. Finally, fats WP was the less efficient, although it was $25 \%$ higher with respect to Current Diet. $_{\text {. }}$

Similar values can be observed for the Blue NWP. In this case, the MedDiet was very efficient in vitamins (175\% higher than the Current $\left.{ }_{D i e t}\right)$. Med Diet $_{\text {was }}$ also very efficient (although not as much as vitamins) in comparison with Current $t_{\text {Diet }}$ in fiber (62\% higher), minerals (55\% higher), carbohydrates (46\%), and energy and water (44\% each higher). The less efficient values relate to proteins (38\% higher) and fats (23\%).

With respect to Grey NWP value, there were some nutritional components with higher

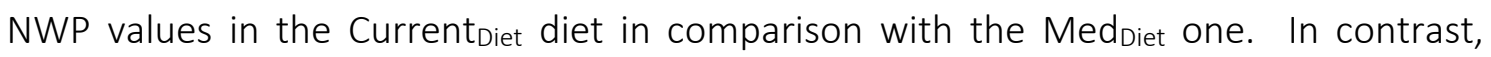
Current $_{\text {Diet }}$ was more efficient in energy and fiber (2\% both), minerals (3.5\%), but especially for fats (11\%) and proteins (52\%). The remaining NWP values were higher with a Med $d_{\text {Diet }}$ diet (as the Green and Blue ones): vitamins (122\% higher), carbohydrates (40.5\% higher) and water (12\% higher). 
On average, NWP values for Blue and Green water exhibited greater efficiencies in all nutritional components for those food groups that are consumed more in MedDiet, i.e. "Fruits and vegetables", "Cereals, olive oil and healthy drinks", "Olives, nuts, seeds and condiments" and "Eggs and Legumes" respectively 58\%, 42\%, 260\% and 44\% higher than those for the CurrentDiet. The group of "Fish and seafood" had the same NWP values for both diets due to its null WF.

On the other hand, "Dairy products" was $48 \%$ lower in MedDiet than in Current Diet, "Potatoes" 67\% lower, "White Meat and Vegetable fats" 63\% lower, "Red/processed meat" 79\% lower, and "Sugar, sweets, sauces and beverages" 95\% lower. 




Figure 4-10. Nutritional Water Productivity (NWP) for Blue and Green water (consumptive use) in Mediterranean Diet in comparison with Current Spanish Households Consumption for all the nutritional components in nutritional values/ liter of water. Source: own elaboration. 


\subsubsection{DISCUSSION}

\section{Consumption patterns}

Over the last two decades, many studies within the Mediterranean region show that consumption patterns in countries like Spain, Italy and Greece are shifting towards more Western ${ }^{1}$ and unhealthier diets (Baldini et al., 2009; Bonaccio et al., 2012; Da Silva et al., 2009; Naska et al., 2006; Serra-Majem et al., 2004). Southern European countries are rapidly changing these patterns towards the consumption of more refined grains, animal fats, sugars and processed meats, and fewer legumes, cereals, fruits and vegetables (Bonaccio et al., 2012).

Besides, other authors concluded that Mediterranean countries have increased meat consumption levels in recent years, even surpassing Northern European countries (Naska et al., 2006). These authors compared dietary patterns in ten European countries and concluded that the dietary pattern differences between Northern and Southern European countries were gradually narrowing, the only big difference being higher legumes and olive oil consumption in the Mediterranean countries. Additionally, Da Silva et al. (2009) analyzed the worldwide trends of adherence to a recommended Mediterranean diet, comparing two periods (1961/65 and 2000/03), using FAO Food Balance Sheets. Over these 40 years, while Mediterranean countries experienced the greatest decrease in a Mediterranean-like dietary pattern, Northern European and some other countries (like Iran or Japan) were getting closer. In the case of Spain, Bach-Faig et al. (2011b) reported a progressive deviation from the traditional diet during the 1980s, then followed by stabilization and a slight recovery during the early 2000 s.

In a study by Varela-Moreiras et al. (2010) analyzing Spanish household consumption from 2000 to 2006, the meat consumption level was higher than the analyzed Mediterranean recommended diet ( $65 \mathrm{~kg} / \mathrm{cy}, 8 \%$ of total diet). Products, such as cereals $(152 \mathrm{~kg} / \mathrm{cy}, 10 \%$ of total diet), vegetables-potatoes-fruits ( $211 \mathrm{~kg} / \mathrm{cy}, 25 \%$ of total diet), and legumes ( $5 \mathrm{~kg} / \mathrm{cy}, 0.6 \%$ of total diet) were being consumed at levels below Med Diet recommendations.

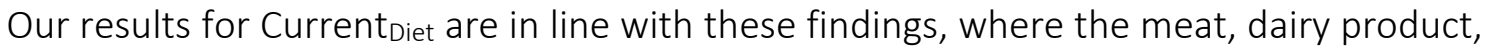
and sugar-sweet groups accounted for $39 \%$ of total consumption compared with $11 \%$ for MedDiet. In other words, we have to reduce the intake of sugar, sweets, sauces and beverages by $86 \mathrm{~kg} / \mathrm{cy}$, red/processed meats by $25 \mathrm{~kg} / \mathrm{cy}$, white meat-vegetables fats by $15 \mathrm{~kg} / \mathrm{cy}$ and dairy products by $50 \mathrm{~kg} / \mathrm{cy}$, and increase the intake of fruits-vegetables by $100 \mathrm{~kg} / \mathrm{cy}$, and cereals by $51 \mathrm{~kg} / \mathrm{cy}$ to follow a recommended Med Diet.

\footnotetext{
${ }^{1}$ Western diet is a diet loosely defined as high in saturated fats, red meats, 'empty' carbohydrates - "junk food" - and low in fresh fruits and vegetables, whole grains, seafood or poultry (Segen, 2012).
} 
Varela-Moreiras et al. (2010) also concluded that some traditional staple foods like bread or olive oil showed a decline when compared with 1964 household surveys (Varela et al., 1971). Comparing our results with the 1964 findings, we also appreciate a decrease in consumption: bread from $134 \mathrm{~kg} / \mathrm{cy}$ in 1964 to $35 \mathrm{~kg} / \mathrm{cy}$ in 2014/15, and olive oil from 19 $\mathrm{kg} / \mathrm{cy}$ in 1964 to 8.5 in 2014/15. We also find that, over the last 50 years (from 1964 to 2014/15), meat consumption increased from 28 to $55 \mathrm{~kg} / \mathrm{cy}$, dairy products from 83 to $104 \mathrm{~kg} / \mathrm{cy}$, and fish/seafood from 23 to $27 \mathrm{~kg} / \mathrm{cy}$. Instead, fruits-vegetables (potatoes included) decreased from 220 to $201 \mathrm{~kg} / \mathrm{cy}$. Nonetheless, meat and dairy product consumption decreased from 2000 (Varela-Moreiras et al. 2010) in comparison to our results of 2014/15.

Current consumption patterns have changed significantly over the last decades in Spain and other Mediterranean countries. In the case of Spain, Bach-Faig et al. (2011b) revealed that many socio-cultural and economic changes across the last few decades appear to be responsible for this shift. After 1975, Spain underwent a rapid transition towards democracy and joined the EU, with increasing incomes, rapid urbanization, or technical improvements in the food industry. Another change was globalization, with its commercial, economic, regulatory, and technological and communication influences. Bach-Faig et al. (2011b) also reported other factors that significantly changed food demand and habits, such as female labor market participation, smaller household sizes, growing immigrant population, increased food consumption outside the home, Westernization of cooking habits and more leisure activities.

\section{Nutritional analysis}

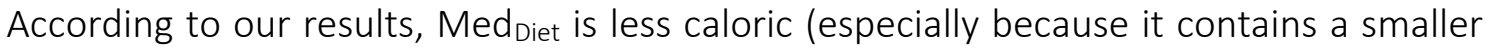
amount of proteins and fats) and has higher fiber, water, and micronutrient (vitamins and minerals) levels. Some studies established that depending upon demographic and other sociocultural factors, the energy intake for a healthy diet requirement ranges from 2,000 to $2,500 \mathrm{kcal} / \mathrm{cd}$ (SIWI, 2015) for an adult person. Other studies establish that an average daily per capita intake requirement is of the order of 2,000-2,200 kcal (Lundqvist and Unver, 2018). Our results showed that Med Diet $_{\text {energy was } 1860 \mathrm{kcal} \text {, while Current }}$ Diet was $2182 \mathrm{kcal}$. If we take into account that household food consumption accounted for only $75 \%$ of daily food intake, the results for energy level are $2325 \mathrm{kcal}$ for Med $\mathrm{Diet}_{\text {and }}$ $2727 \mathrm{kcal}$ for Current Diet, supposing that the rest of the food intake is outside homes.

Nonetheless, our results only assess the total food consumption understood as household food shopping, that is, food waste values have to be subtracted from consumption values in order to assess the final food intake.

Many studies have considered Med Diet as a healthy consumption pattern benchmark (Davis et al., 2016; Rosi et al., 2017) and compared the differences against other, not so allegedly healthy diets, like current Western patterns or meat-based diets, or with 
socioeconomic factors (Bonaccio et al., 2017). On the other hand, other studies also have made comparisons with other supposedly healthier diets, like a pescetarian, vegetarian, ovo-lacto-vegetarian, vegan, or even flexitarian (Springmann et al., 2018) diets. But what is a healthy diet? According to the World Health Organization (WHO, 2015), based on a previous study by the WHO Expert Committee (WHO and FAO, 2003), a healthy diet should be capable of helping to prevent all forms of malnutrition, as well as a range of diseases and conditions. For a healthy diet, WHO recommended: a) more than 400 grams of fruits and vegetables per person per day, b) a less than $10 \%$ share of sugar-sweets of total kcal, c) a $30 \%$ share of fats within total ingested kcal, and d) less than 5 grams of salt per person per day.

Our results showed that the MedDiet fulfills three of these four requirements: 742 grams of fruits and vegetables, $1 \%$ of sugar and sweets within total kcal and less than 5 grams

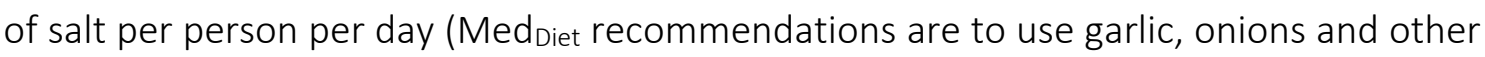
natural spices instead of salt). On the other hand, Current $_{\text {Diet }}$ meets only two requirements: 468 grams of fruits and vegetables and 3.3 grams of salt per capita per day (which constitute worse values than for the Med Diet). Finally, in terms of fats, neither diet meets the requirement: the fats share of Med Diet $_{\text {and Current }}$ Diet was 36\% and $42 \%$ of total kcal, respectively, where again Med Diet was better positioned.

Looking at Spanish food consumption over the last few decades (Varela-Moreiras et al., 2010 ) in comparison with our results, we find that nutrition intake levels have changed. Varela-Moreiras et al. (2010) compared the contribution of alcohol and macronutrients to total energy consumption from 1964 (Varela et al., 1971) to 2006. Figure 4-11 compares these results with ours (current consumption and Mediterranean diet in

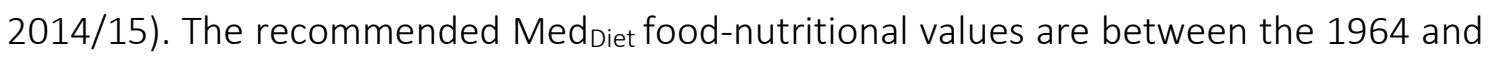
1981 levels, i.e., the same patterns as Spanish household consumption 40 to 50 years ago.

These results are consistent with findings reported by Bach-Faig et al. (2011b), concluding that Spain gradually deviated from the traditional diet as of the 1980s. The nutritional results of this study help to evaluate the direct and indirect correlations between the nutritional, health and environmental indicators of the Mediterranean diet (Dernini and Berry, 2015). 


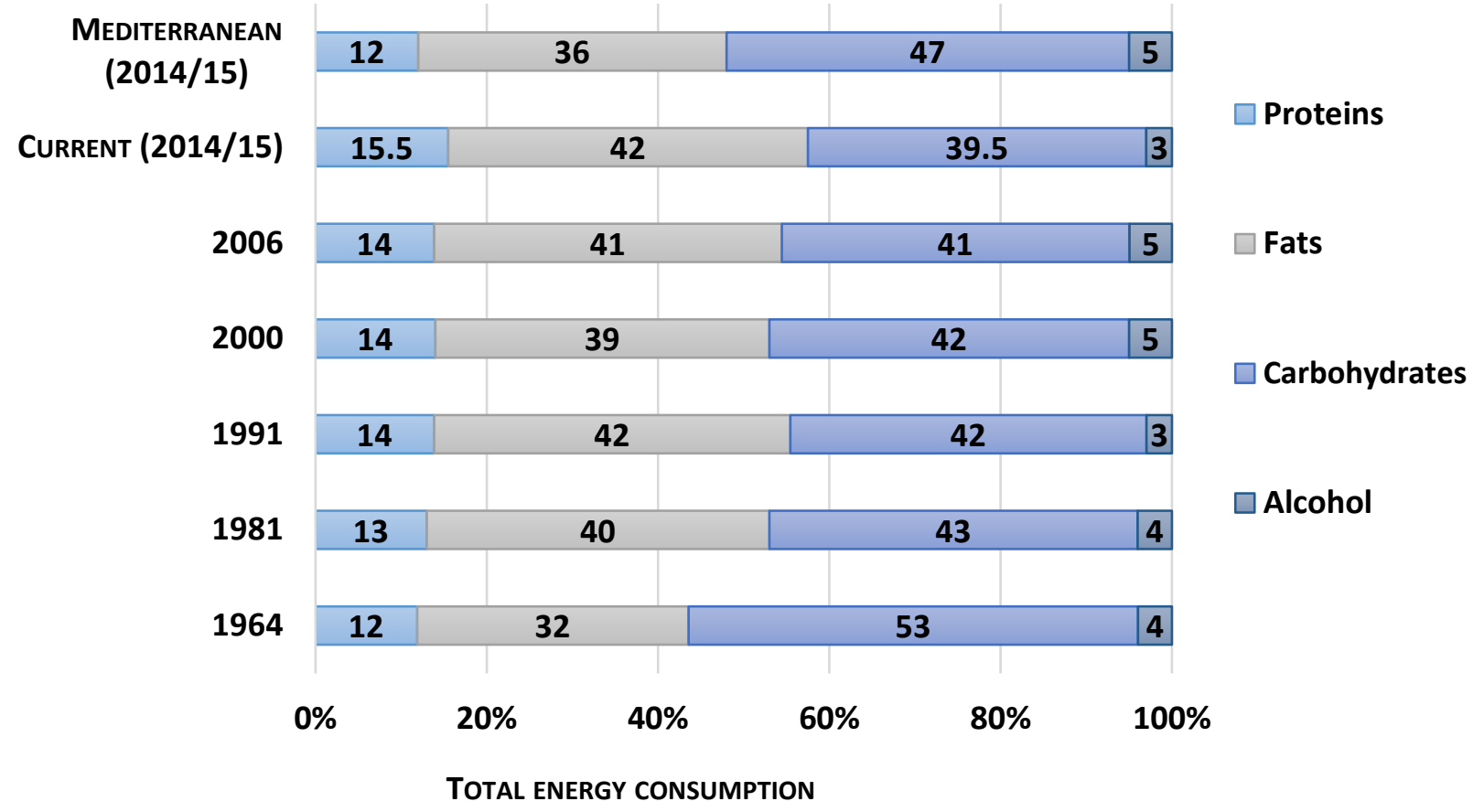

Figure 4-11. The share of proteins, fats, carbohydrates, and alcohol in the total energy consumption (\%) for Spanish food consumption over the last decades (own elaboration based on the comparison of the data reported by Varela-Moreiras et al. (2010) and our results for current consumption and the Mediterranean diet in 2014/15).

\section{Water Footprints}

Significant WF reductions can be achieved by adopting a MedDiet. Focusing on the consumptive use of water (green + blue WFs), 753 liters per capita day can be reduced by consuming a MedDiet. This means that the country as a whole could reduce the consumptive WF by $275 \mathrm{~m}^{3}$ per capita, or a total of 12,072 million $^{3}$.

As an illustrative example of our results, if Spanish households followed a MedDiet instead of a Current Diet pattern, with a blue WF saving of $12.5 \mathrm{~m}^{3} / \mathrm{cy}$, there would be enough water to irrigate 10 million tons of wheat, or 7 million tons of potatoes, or 3.5 million tons of oranges, or 24 million tons of tomatoes or even to produce 209 thousand tons of olive oil. In other words, 547 million $\mathrm{m}^{3}$ would be available for agricultural, industrial, and other purposes (like municipal water supply).

With total consumptive WF reductions of $36 \%$ of Med Diet $_{\text {compared with Current }}$ Diet, our results are within the ranges reported by Sáez-Almendros et al. (2013): reductions of around 33\% following a Mediterranean diet instead of Western dietary patterns. They are also consistent with findings by Vanham et al. (2018), reporting WF reductions of $11 \%$ 
to $35 \%$ through the consumption of healthy meat diets (like the Mediterranean model) in the UK, France, and Germany.

Other comparisons between the recommended Mediterranean and other Western meatbased dietary patterns have been reported (Davis et al., 2016; López-Gunn et al., 2012), again concluding that a Mediterranean diet results in major WF reductions.

The products that accounted for the largest share of WFs were of animal origin: meats, animal fats, and dairy products. Animal origin products accounted for the final 50\% (1641 I/cd) of total WF in Current Diet, as opposed to only 606 liters/cd in the Med Diet (25\%). These results are consistent with findings by studies suggesting that diets based on legumes, vegetables and fruits consumption (or totally vegetarian) lead to larger water savings than eating habits based on the consumption of livestock products or nonvegetarian diets (Jalava et al., 2014; Marlow et al., 2009; Vanham et al., 2013a, 2013b). Moreover, Poore and Nemecek (2018) estimated big freshwater savings not only by moving to diets excluding animal products but also through producer practices on the studied farms, highlighting that production practices do indeed matter for blue water savings.

Finally, the green WF accounted for the biggest share of total WF for both diets: $77 \%$ in

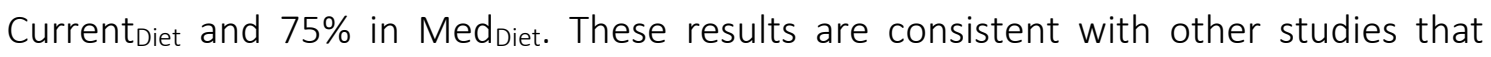
concluded the dominance of green water in food production (López-Gunn et al., 2012; Vanham et al., 2013a, 2013b). Blue WF accounted for $12 \%$ and $15 \%$ of the total WF in CurrentDiet and Med Diet, respectively.

\section{Nutritional Water Productivity (NWP)}

A few years after the NWP concept was developed by Renault and Wallender (2000), the Stockholm International Water Institute (SIWI and IWM, 2004) promoted the "More Nutrition per Drop" strategy, going beyond the previous motto "More Crop per Drop", especially to the population with nutritional problems. Renault and Wallender (2000) also reported that a water-food link is crucial for nutrition and livelihood security in poor rural communities. In the past, some studies have been conducted to analyze dietary energy and water or water use related to protein content (Gephart et al., 2014; Jalava et al., 2014). Even so, more research is needed to highlight the need to link water use in agriculture with food and nutrition security and improve human health.

Wenhold et al. (2012) applied the NWP index to study the water use and nutrient content of food products in South African households. In a recent review about the water-foodnutrition-health nexus, Mabhaudhi et al. (2016) concluded that NWP is the most useful index to address agricultural water use impacts in food and nutrition security. They also deduced that it is essential to promote this kind of metrics to improve human nutrition and health in poor rural communities. 
Moreover, the United Nations Food and Agriculture Organization (FAO) has been working over the last few years to develop the NWP methodology and link water and agricultural strategies to improve food security and nutrition. It follows a strategy to enhance awareness about the linkages between water and nutrition and achieve nutritional and health-related SDGs.

Nevertheless, literature about NWP in food products and diets is still limited. Moreover, the methodological approach used in this study has new and different dimensions, components and applications, and our results are hard to compare with others. We applied Renault and Wallender's NWP concept to diet composition, taking into account national production and imports and conducting a WFA.

Our results showed that Med Diet $_{\text {is }}$ more water-nutritional efficient than Current $t_{\text {Diet. }}$ This means that a MedDiet provides more energy, fiber, and macro- and micronutrients than

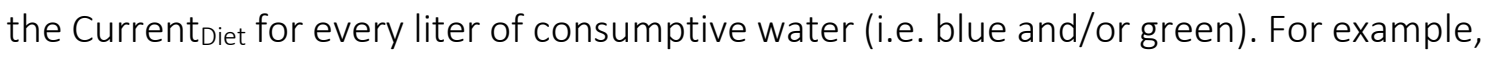
with one liter of irrigation water (blue WF), the consumer of a Med Diet gets $1033 \mathrm{kcal}, 231$ grams of macronutrients and 6.3 grams of micronutrients, whereas the consumer of a Current $_{\text {Diet }}$ gets only $720 \mathrm{Kcal}, 162$ grams of macronutrients and 3.7 grams of micronutrients. Similar values are observed for the green NWP (Figure 4-10). As already highlighted by earlier studies (Renault and Wallender, 2000; Wenhold et al., 2012), a greater proportion of animal products - meat and dairy -- with large water footprints make diets significantly water-nutrient inefficient, even though they are relatively rich in nutrients like protein or fats.

Finally, Figure 4-10 also reveals higher values for the blue NWP than the green NWP. A possible explanation is that NWP, as the inverse of WF (like water productivity), has lower values when WF values are high (like the green WF of every food product in this case). In other words, a person would need more green water (11 milliliters) than blue water (1.4 milliliters) to get the same amount of nutritional values, e.g. $1 \mathrm{kcal}$ in the Current Diet. 


\section{CONCLUSIONS AND FUTURE RESEARCH}

\subsection{MAJOR FINDINGS AND CONCLUSIONS}

Achieving more sustainable food security is a world priority, therefore studies addressing food consumption habits and their associated nutritional-environmental benefits are key to ensure the achievement of some of the $\operatorname{SDGs}(2,3$, and 6), but especially SDG 12: responsible consumption and production. This thesis contributes to SDG 12 by means of new assessments and studies of responsible consumption patterns, food waste reduction, and resource productivity to meet food needs. It also contributes by linking the spheres of topics related to water, agriculture, food security, nutrition, environment, and health.

Seeking to fill some knowledge gaps in the water and nutritional impacts of different diets patterns and food waste, this section presents the thesis's following general conclusions and major findings that answer the general objective of this research raised under two questions:

\subsubsection{HOUSEHOLDS' FOOD CONSUMPTION IS SHIFTING AWAY FROM HEALTHY, TRADITIONAL, LOCAL, AND RECOMMENDED MEDITERRANEAN TRENDS}

Our assessment confirms that the actual food consumption patterns of Spanish households are shifting away from the traditional and recommended Mediterranean pattern, towards a more Western and unhealthy-diet, containing 3 times more meat, dairy and sugar products, and a third fewer fruits, vegetables, and cereals, than the recommended one. This conclusion is aligned with the findings of other studies (Bonaccio et al., 2012; Serra-Majem et al., 2004; Tur et al., 2004), that also concluded changing consumption patterns in the Mediterranean area.

Our study confirms that the consumption of animal origin products (meat, eggs, and dairy products) and fats is almost the same (168 kg per capita year) as the amount of food consumed from both the fruits and vegetables groups altogether (171 kg per capita year). In order to follow a traditional and recommended Mediterranean Diet, vegetables and fruits' consumption has to by more than 3 times higher than meat, fats, eggs, and dairy products together (271 and $82 \mathrm{~kg}$ per capita year respectively).

In addition, to follow the traditional and recommended Mediterranean diet, the group of sugar, sweets, sauces, and beverages ought to be reduced by $86 \mathrm{~kg}$ per capita year, red and processed meats by $25 \mathrm{~kg}$ per capita year, white meat-vegetables fats by $15 \mathrm{~kg}$ per 
capita year and dairy products by $50 \mathrm{~kg}$ per capita year. On the other hand, fruits and vegetables ought to be increased by $100 \mathrm{~kg}$ per capita year and cereals by $51 \mathrm{~kg}$ per capita year.

The Mediterranean diet's nutritional values are in accordance with those documented in Spanish households' consumption 40-50 years ago, during the 1970's decade. While the current food consumption (from October 2014-September2015) one keeps the trend initiated in the 1980s, with more percentage of proteins and fats and fewer carbohydrates.

Regarding food virtual water imports associated with the current households' diet, much of the total water used (41\%; 21,544 million $\mathrm{m}^{3}$, of which 20,402 is consumptive, i.e., Blue + Green WF) for producing the food consumed in Spain is foreign (virtually imported). This confirms the expansion of globalization and the rise and importance of the growing global food trade and its volume of associated water instead of locally and nationally produced food consumption.

Only five countries -- Tunisia, Portugal, France, Ivory Coast, and Brazil--, accounted for about $40 \%$ of the total imported water to Spain. Within a sub-continent basis, $28 \%$ comes from Western Europe, being Portugal, France, and Germany three of the top-ranking six countries, accounting for $21 \%$ of the total. Spain relies significantly on imported $V W$ from many large agricultural producers.

\subsubsection{CONSEQUENCES OF THE SHIFTING AWAY FROM RESPONSIBLE FOOD CONSUMPTION PATTERNS (SDG 12) AS MEDITERRANEAN DIET AND A REDUCTION OF FOOD WASTE, IN TERMS OF WATER AND NUTRITIONAL IMPACTS}

This study is one of the few that evaluates the water footprint of real recommended and daily menus, using traditional and national-local recipes and dishes with individual products analysis. In addition, this study is also one of the few encountered in the literature so far that has quantified the WF of the actual consumption and waste levels within households.

The traditional and recommended Mediterranean Diet can be considered more as a sustainable diet; not only in terms of healthier effects but also due to its lower water and nutritional impacts. Therefore, adopting a Mediterranean diet would lead to major water savings in comparison with the recommended American one, both in Spain and in the US. There would be water consumptive (Green + Blue WF) savings equivalent to 1277 liters per capita day in Spain by maintaining a Mediterranean diet, instead of consuming an American recommended one (of which 411 liters/capita day is Blue WF). Similar values were obtained in the US, where changing from an American recommended diet to a Mediterranean one, will imply a net reduction of 1252 liters of consumptive water capita day (mainly because Green WF). 
The total annual WF of current Spanish households consumption, taking into account imported food products (and therefore imported water), was, on average, 1,205 $\mathrm{m}^{3}$ per person, equivalent to 3,302 liters per capita day. Of which the green fraction accounted for around 2,554 and the blue 400 liters per capita day.

Because the products that accounted for the largest share of current consumption WF (47\%) were animal' origin ones: meats, animal fats, and dairy products (only $25 \%$ in the Mediterranean diet), 753 liters per person and day of consumptive water (of which 34 are Blue WF) could be reduced if the Mediterranean Diet would be maintained reversing observed actual food trends.

Regarding nutritional benefits, the recommended Mediterranean Diet is less caloric, especially because it contains less quantity of proteins and fats, than the current consumption trends, and has higher fiber, water, and micronutrients (vitamins and minerals). Our results showed that for the 12-month period from 1 October of 2014 to 30 September of 2015 , current consumption had $15.5 \%$ proteins, $42 \%$ fats, $39.5 \%$ carbohydrates and $3 \%$ of alcohol in its diet. On the other hand, the results for Mediterranean diet were $12 \%$ proteins, 36\% fats, $47 \%$ carbohydrates, and $5 \%$ alcohol. Likewise, the Mediterranean one has half of the cholesterol levels than the current diet; 39 and 76 mg per capita day respectively.

Our results showed that the Mediterranean diet has a better water-nutritional efficiency (higher NWP levels) than current consumption; more energy, fiber, and macro and micro nutrients are available per liter of consumptive water. With one liter of irrigation water (Blue WF) in the Mediterranean diet, the consumer obtains; $1033 \mathrm{kcal}, 231$ grams of macronutrients and 6.3 grams of micronutrients, while only; $720 \mathrm{Kcal}, 162$ grams of macronutrients and 3.7 grams of micronutrients in the current consumption diet. These means that a) more water is needed to obtain the same level of nutrients if Current Consumption is consumed, and b) the Mediterranean Diet fits in the "More Nutrition per Drop" strategy promoted these last years by institutions like SIWI and FAO.

Results, therefore, showed that the benefits linked to embracing the Mediterranean diet are not just rooted in its health-nutritional potential benefits, but also it is a less waterintensive diet. Therefore, our findings support the conclusion that diets based on low meat consumption could also be more environmentally sustainable in terms of water savings, contributing to addressing the health-environment problem.

Changing consumption patterns towards recommended diets based on a high intake of vegetables, fruits, and fish, like the Mediterranean diet, and/or cutting down animal origin products consumption, would deliver nutritional benefits and significant water savings (last ones, in some cases larger than those associated to increasing efficient production).

A few products have a large influence and account for the major part of the Water Footprint of diets: meat, oils, fats, and dairy products are the most influential and 
important ones. In the American diet recommended by USDA, the products which accounts the most for the final WFs values in both countries are animal origin ones: semiskimmed milk and beef meat. On the other hand, olive oil is the product that contributes the largest percentage of water footprint in the Mediterranean diet, in both countries.

Further research is needed to evaluate the high green WFs values of olive oil and olives crops. Despite olive plantations being millennial, with local and landscape-adapted trees, their high green WF values make olive oil one of the major water consuming products, even more than meat and dairy. Some studies described olive cultivation as a lowintensity production system, and usually associated with old trees, small yields, and receiving low inputs for both labor and materials (Blondel, 2006). These factors (mainly low yields) probably explain the large WF (particularly green water) of olives and olive oil. In view of the above, further research is needed to evaluate the high green WFs, of these environmental and sustainable endemic adapted crops.

The total amount of annual food waste per home in Spain is $26 \mathrm{~kg}$ per capita year on average. This is equivalent, on an annual basis, to an average food waste of nearly 1.14 million tons nationwide (estimated at around $4 \%$ of total current food household's purchased). This appears to be lower than the results reported in other studies, and possible explanations for the differing results are limitations with respect to data and methods and slightly different definitions of food waste used in different studies. Another plausible reason is that more food is wasted throughout the food supply chain and that Spanish consumers are less wasteful because of a rational or economic behavior. Moreover, more studies are needed in order to unify terminology and methodology.

Clearly, food waste implies the loss of water, that is, the water used to produce the food. Because of household's food that is wasted over a one-year period, 2095 million $\mathrm{m}^{3}$ of water were also wasted nationwide, of which about 848 million $\mathrm{m}^{3}$ are virtually imported from foreign countries. On average, one person wasted $47.7 \mathrm{~m}^{3}$ per year (Total WF), meaning 131 liters per capita day (of which 97 are Green WF and 19 Blue WF), and equivalent to $4 \%$ of the total consumption WF.

However, food waste also implies the loss of nutrients, that is, the nutrients that are lost in the last part of the food chain because of consumers' wasteful behavior. Our results indicated that because of annual food waste in Spanish households, the nutrients wasted per capita per year were $40,385 \mathrm{kcal}$, almost $7.5 \mathrm{~kg}$ of macronutrients (1.5 kg of proteins, $1.8 \mathrm{~kg}$ of fats and $4.2 \mathrm{~kg}$ of carbohydrates), 483 grams of fiber and almost 160 grams of micronutrients (19 $\mathrm{g}$ of vitamins and $141 \mathrm{~g}$ of minerals). This means, in relation with the nutritional analysis of current Spanish households' consumption, that around $5 \%$ of energy ( $\mathrm{kcal}$ ), $5 \%$ of proteins (and the rest of macronutrients), $8 \%$ of fiber, $4 \%$ of minerals, and $11 \%$ of vitamins are lost due to food waste within households.

In other words, if food had not been wasted in the whole country, and due to the total loss of kcal that entails, there would have been energy requirements (of around 2200 
$\mathrm{kcal} /$ capita day) to feed almost 2.2 million people. Alternatively, even to feed a single person for 18 entire days.

In addition, the food groups that accounted more for the loss of energy were from animal origin; meats, fats, and dairy products: $22 \%$ of total kcal wasted. This is mainly because of the large share that these groups accounted for the final waste of proteins (39\%), and fats (38\%). These groups also contributed to almost $30 \%$ of the total minerals wasted. In light of these results, where the greatest rates of energy and proteins loss were associated with livestock production, not only environmental but also nutritional impacts can be attributed to animal origin products. If animal products' consumption is reduced within Spanish current household's diet and the quantities that are consumed would not be wasted, big water and nutritional savings would be achieved from a consumer perspective.

The largest share of the WF of diets and food waste (>65\%) is always linked to green water. These results are in accordance with other studies that concluded the dominance of green water in food production. This means that not only irrigation water savings (Blue WF) can be achieved consuming a Mediterranean diet, but also fewer impacts in land uses can be attained. Nevertheless, the grey WF is considerably larger in the US despite the diet consumed, mainly because of larger nitrogen pollution in water resources caused in the production of legumes and nuts.

Finally, more water savings can be achieved when:

Efficient production systems coexist with sustainable consumption patterns. A further conclusion indicates that the origin of the products (prevailing climate and production conditions) also matters, and it is a very important factor to minimize water footprints: the lowest values of the two recommended diets in Spain and the US appear for the Mediterranean diet in the US.

$>$ Our results show that from the Spanish perspective, households could achieve a larger reduction in their food-related WFs changing eating habits rather than just avoiding food waste. A total of 884 liters per capita day of consumptive water can be reduced in total by combining shifting consumption patterns to a Mediterranean Diet and avoiding food waste. If we look at the results of the last national study on the supply of drinking water and sanitation in Spain during 2017 (AEAS and AGA, 2018), the total water use in Spanish households (drinking, washing, cooking, toilet, shower, cleaning......etc.), was, in average; 132 liters per capita day. Regarding only irrigation water (Blue WF), shifting to a Mediterranean Diet would imply saving of 34 liters per capita day, and avoiding food waste savings of 19 liters per capita day. This means that a total of 53 liters of irrigation water per capita day can be saved by combining dietary changes adopting a Mediterranean Diet together with avoiding food waste. This potential saving 
equals nearly 1 shower of five minutes' per capita day and $40 \%$ of all the other personal consumptive domestic purposes (drinking, washing, cooking, toilet, and shower, cleaning...etc.).

This study demonstrates how important diets are for consumers and the environment, and supports other studies, which argue that diets and food waste do matter when referring to sustainability. The results of the thesis can make this message more likely be embraced by the public, providing knowledge about the environmental impacts of current consumption patterns and in particular linked to diets and food waste.

As a final conclusion: It appears that reduced food waste and the preservation and diffusion of the traditional and recommended Mediterranean diet, at least for those countries whose culture recognizes it as a cultural heritage, should be a priority in order to achieve water use and nutritional benefits and the consecution of SDG 12.

\subsection{LIMITATIONS AND FUTURE RESEARCH}

\subsubsection{LIMITATIONS OF THE STUDY}

Although this thesis contributes with knowledge and findings to provide a holistic view of the assessment of the water and nutritional impacts of recommended diets, food waste and actual trends, there are still many aspects that could not be addressed. A summary of them includes the following:

General data and methodology limitations:

- WF concept and WFA methodology approach have many conceptual and technical limitations. These limitations are widely explained, among others, by Hoekstra et al. (2011), pages: 115-118. Moreover, a summary of the most important ones concerning the crops and livestock blue, green and grey data and calculations can also be seen in Mekonnen and Hoekstra, (2011, 2012).

Some of these limitations for food crop calculations are (Mekonnen and Hoekstra, 2011, pp. 1596-1597): the availability of crop-specific irrigation maps, the planting and harvesting days variations within countries, soil's water holding capacity data, the possible overestimation of blue WF (due to irrigation is always assumed to be maximum, i.e, sufficient enough to meet the irrigation requirement), availability of fertilizer applications rates, the assessment of grey WF (estimated based on a simplified approach, which gives a rough estimation), 
the simplified model used to estimate the yield, and the neglect of intercropping and multi-cropping.

For animal products (Mekonnen and Hoekstra, 2012, p. 412): the availability of data on animal distribution per production system per country for OECD countries, or the lack of data of indirect water footprints of materials used in feed production and animal raising.

- Further research is required to assess the sustainability of diets, e.g., through LCA impact (Kounina et al., 2012) or by conducting a sustainability WFA (Hoekstra et al., 2011), since the WF of diets only provides insight on the amount of water embedded in food production, regardless of the impacts such water consumption generates in the production regions.

- Other methodological approaches for accounting water savings in food products different from LCA and WFA can be addressed, e.g., ISO 14046, and would offer benchmarking opportunities to assess the impact of using different methodologies.

- Previous research has found that WF estimations for the same products and countries can differ significantly (Chico et al., 2010; De Miguel et al., 2015; Salmoral et al., 2011). The specific local climate and agricultural practices have a large effect on the WF of products. Therefore, the thesis results would gain by making sensitivity analyses resulting from using different evaluations of WF for the most critical products. In addition, more national and local studies are needed: the wide range of WF estimations for the same products and countries requires a detailed comparison of the values reported by Mekonnen and Hoekstra, (2011, 2012).

- The unit WF databases refer to the average years 1996-2005, while most analyses refer to years 2014-2016.

- In most Spanish irrigation systems (especially in non-horticultural crops), possible over-estimation of Blue WF results have been assessed, as explained above. Moreover, national Spanish productions are located: cereals and grains in the central plateau and fruits and horticulture in the south and east of the peninsula.

- Different food groups have been considered in the thesis. So, in each of them, all the food products have been divided into different food groups. This allowed a better comparison of main food patterns, but certainly other classifications are possible, and some assumptions may drive the quantitative differences found in the thesis that would deserve more elaboration. 
Specifically, for the first research study: Evaluating the water footprint of the Mediterranean and American diets, the following limitations prevail:

- Results of this research showed that olive oil is the product accounting for a large share of the Mediterranean WF in both countries. Olive has been cultivated for millennia in the Mediterranean region and has been considered a symbol of environmental sustainable systems, but with old trees and low yields. In view of the above, further research is needed to evaluate the high green WFs. Having olive oil such important impact in the Mediterranean diet's WF, it is necessary to evaluate the impact of more intensive or less intensive production systems, including the irrigation techniques.

Specifically, for the second research study: Food consumption and waste in Spanish households: water implications within and beyond national borders, the following limitations prevail:

- Further research is required to assess food waste, by not only implementing common methodologies and definitions, but also for understanding which factors can influence consumer behavior.

- The multiple datasets required for this study highlights the difficulties of obtaining estimates of food consumption and waste, and therefore how challenging it becomes to inform policies tackling sustainable food consumption and their relation to water management. More research is needed to develop standard methodological approaches in ways that can provide policy-relevant results and overall contribute to better policymaking. Because of this difficulty, only one-year data (and only studying imports, no exports or re-exports), with their related limitations, has been assessed.

Specifically, for the third research study: A comparison of the Mediterranean diet and current food consumption patterns in Spain from a nutritional and water perspective:

- Literature about nutritional water productivity food products and diets is still limited. Moreover, the methodological approach used in this study has new and different dimensions, components, and applications, making our results barely comparable with others. Although some studies have been carried out over the last few years, further research is thus required to assess the nutritional water productivity of food products in order to obtain more accurate estimations of water-nutrition-health nexus. 


\subsubsection{FUTURE PATHS OF RESEARCH}

Further research is required to assess the WF of the food components that influence the WF of diets the most, in order to obtain estimations that are more accurate. In addition, the estimation and update of the WF values to present years.

Moreover, also an important point would be to check how different are the local/national statistics of food consumption and waste, and food trade, with respect to the FAO international Food Balance Sheets one.

Future paths of research can be assessed in different scale and scope of impacts, in dietary patterns, or in food loss and waste studies. Taking as a base this thesis research studies, more environmental impacts could be addressed in different levels. A possible directional path of research can be seen Figure 5.1, showing also, what this thesis has already addressed.

At a first level, Spanish Households:

- Nutritional Water Productivity analysis assessment could be done regarding food waste.

- Additional environmental "footprints" can be calculated for all food patterns and waste: land and carbon. The first one, land footprint, can be calculated as the inverse of the agricultural yield, in order to quantify the amount of land needed to produce a ton of product (Willaarts et al., 2011). A carbon footprint can be measured as the total carbon dioxide emissions directly and indirectly caused by the whole life of the products within a diet.

- The expansion of the methodology to alternative, healthy, and sustainable diets (such as vegetarian, vegan, flexitarian (Springmann et al., 2018) or New Nordic ones) could be also possible.

- A new approach can also be applied to food waste: including overeating and obesity (and their related impacts) as a part of it. Taking into account not only food waste at the consumer stage but also overeating (overweight and obesity are one of the most spread and dangerous nutritional problems worldwide) as another way of "wasting" food. By trying to integrate and calculate overeating as a food and nutritional waste, we would be able to link this problem to food security and the environment.

- Data obtained from this thesis can be extended to complete five or more year's databases about nutritional values and composition of Spanish households' and Mediterranean diets. 
- Also, from the food loss and waste (including overeating) databases, taking into account the kilograms, nutrients, water, land and carbon emissions wasted (due to food waste in Spanish households) during the last 5-10 years

\section{SCOPE OF IMPACTS}

\begin{tabular}{|c|c|c|c|c|c|c|c|}
\hline & FOOD PATTERN & $\begin{array}{c}\text { WATER } \\
\text { FOOTPRINT }\end{array}$ & $\begin{array}{l}\text { NUTRITIONAL } \\
\text { ANALYSIS }\end{array}$ & $\begin{array}{c}\text { NUTRITIONAL } \\
\text { WATER } \\
\text { PRODUCTIVITY }\end{array}$ & LAND USE & $\begin{array}{l}\text { CARBON } \\
\text { FOOTPRINT }\end{array}$ & $\begin{array}{l}\text { ENVIRONMENTAL } \\
\text { ASSESMENT }\end{array}$ \\
\hline \multirow{8}{*}{ SPANISH HOUSEHOLDS } & MEDITERRANEAN & & & & & & \\
\hline & AMERICAN & & & & & & \\
\hline & CURRENT CONSUMPTION & & & & & & \\
\hline & FOOD WASTE & & & & & & \\
\hline & VEGAN & & & & & & \\
\hline & VEGETARIAN & & & & & & \\
\hline & NEW NORDIC & & & & & & \\
\hline & OVERWEIGHT/OBESITY & & & & & & \\
\hline \multirow{3}{*}{$\begin{array}{l}\text { Other MediterRanean } \\
\text { Countries HouseHolds }\end{array}$} & FRENCH & & & & & & \\
\hline & ITALIAN & & & & & & \\
\hline & TURKISH & & & & & & \\
\hline \multirow{5}{*}{ OUTSIDE HOME'S LEVEL } & RESTAURANTS & & & & & & \\
\hline & HOSPITALS & & & & & & \\
\hline & SCHOOLS & & & & & & \\
\hline & UNIVERSITIES & & & & & & \\
\hline & FOOD LOSS & & & & & & \\
\hline
\end{tabular}

Figure 5-1. Future research possible studies: scope and scale of impacts and food patterns. In grey color, what has been addressed in the present thesis work and with no color the future pathways.

Using Spanish households as a pilot case, the study could be expanded to other Mediterranean countries, assessing the current consumption, food waste levels and recommended national diets of countries like France, Italy, Greece, Turkey, etc. and compare them with the Spanish ones.

Moreover, an assessment of the consumption out-of-home should provide further conclusions. This could be addressed by taking and analyzing data from different consumption patterns outside houses: restaurants, bars, hospitals, schools, public institutions, caterings, workplaces... Also taking into account the food loss, i.e., the loss of the food wasted in the first stages of the food chain (production, transformation or distribution levels).

With the results and comparisons obtained, some policy recommendations could be drawn in order to promote more nutritional and sustainable diets like the Mediterranean one, bringing closer to consumers (especially to young and urban population) this traditional lifestyle. 


\section{REFERENCES}

AEAS, AGA, 2018. XV Estudio Nacional de Suministro de Agua Potable y Saneamiento en España 2018.

Aleksandrowicz, L., Green, R., Joy, E.J.M., Smith, P., Haines, A., 2016. The Impacts of Dietary Change on Greenhouse Gas Emissions, Land Use, Water Use, and Health: A Systematic Review. PLoS One 11, e0165797. https://doi.org/10.1371/journal.pone.0165797

Alexander, P., Brown, C., Arneth, A., Finnigan, J., Moran, D., Rounsevell, M.D.A., 2017. Losses, inefficiencies and waste in the global food system. Agric. Syst. 153, 190200. https://doi.org/10.1016/j.agsy.2017.01.014

Alexandratos, N., Bruinsma, J., 2012. World agriculture towards 2030/2050: the 2012 revision. ESA Work. Pap. No. 12-03. Rome, FAO. https://doi.org/10.1016/S02648377(03)00047-4

Allan, J. a T., 2003. Useful Concept or Misleading Metaphor ? Virtual Water: A Definition. Water Int. 28, 4-11. https://doi.org/10.1080/02508060.2003.9724812

Altieri, M.A., Rosset, P., 1999. Ten reasons why biotechnology will not ensure food security, protect the environment and reduce poverty in the developing world. AgBioForum 2, 155-162.

ANFABRA, 2017. Asociación de Bebidas Refrescantes [WWW Document]. URL http://www.refrescantes.es (accessed 9.1.17).

Asemac, 2016. Asociación española de la Industria de Panadería, Bollería y Pastelería [WWW Document]. URL http://www.asemac.es (accessed 11.1.16).

ASOZUMOS, 2016. Asociación Española de Fabricantes de Zumos [WWW Document]. URL http://www.asozumos.org (accessed 6.20.11).

Ausubel, J.H., Wernick, I.K., Waggoner, P.E., 2013. Peak Farmland and the Prospect for Land Sparing. Popul. Dev. Rev. 38, 221-242. https://doi.org/10.1111/j.17284457.2013.00561.x

Bach-Faig, A., Berry, E.M., Lairon, D., Reguant, J., Trichopoulou, A., Dernini, S., Medina, F.X., Battino, M., Belahsen, R., Miranda, G., Serra-Majem, L., Aranceta, J., Atinmo, T., Barros, J.M., Benjelloun, S., Bertomeu-Galindo, I., Burlingame, B., CaballeroBartolí, M., Clapés-Badrinas, C., Couto, S., Elmadfa, I., Estruch, R., Faig, A., Fidanza, F., Franceschi, S., Hautvast, J., Helsing, E., Julià-Llobet, D., La Vecchia, C., Lemtouni, A., Mariné, A., Martínez-González, M.A., Mokni, R., Mombiela, F., Noain, I., Obrador, B., Pekcan, G., Piscopo, S., Raidó-Quintana, B., Ros, E., Sáez-Almendros, S., Salas-Salvadó, J., Sensat, F., Trichopoulos, D., Tur, J.A., Vaz Da Almeida, M.D., Willett, W.C., Amiot-Carlin, M.J., Bellio, A., Cannella, C., Capone, R., Cassi, D., Donini, L.M., Lacirignola, C., Maiani, G., Mancini, M., Merendino, N., Padilla, M., Padulosi, S., 2011a. Mediterranean diet pyramid today. Science and cultural updates. Public Health Nutr. 14, 2274-2284. 
https://doi.org/10.1017/S1368980011002515

Bach-Faig, A., Fuentes-Bol, C., Ramos, D., Carrasco, J.L., Roman, B., Bertomeu, I.F., Cristià, E., Geleva, D., Serra-Majem, L., 2011b. The Mediterranean diet in Spain: Adherence trends during the past two decades using the Mediterranean Adequacy Index. Public Health Nutr. 14, 622-628. https://doi.org/10.1017/S1368980010002752

Baldini, M., Pasqui, F., Bordoni, A., Maranesi, M., 2009. Is the Mediterranean lifestyle still a reality? Evaluation of food consumption and energy expenditure in Italian and Spanish university students. Public Health Nutr. 12, 148-155. https://doi.org/10.1017/S1368980008002759

Baroni, L., Cenci, L., Tettamanti, M., Berati, M., 2007. Evaluating the environmental impact of various dietary patterns combined with different food production systems 279-286. https://doi.org/10.1038/sj.ejcn.1602522

Beretta, C., Stoessel, F., Baier, U., Hellweg, S., 2013. Quantifying food losses and the potential for reduction in Switzerland.Supplementary Information. Waste Manag. 33, 764-773. https://doi.org/10.1016/j.wasman.2012.11.007

Berger, M., Finkbeiner, M., 2010. Water footprinting: How to address water use in life cycle assessment? Sustainability 2, 919-944. https://doi.org/10.3390/su2040919

Bhardwaj, D., Ansari, M.W., Sahoo, R.K., Tuteja, N., 2014. Biofertilizers function as key player in sustainable agriculture by improving soil fertility, plant tolerance and crop productivity Biofertilizers function as key player in sustainable agriculture by improving soil fertility, plant tolerance and crop pr 13, 1-10. https://doi.org/10.1186/1475-2859-13-66

Biewald, A., Rolinski, S., Lotze-Campen, H., Schmitz, C., Dietrich, J.P., 2014. Valuing the impact of trade on local blue water. Ecol. Econ. 101, 43-53. https://doi.org/10.1016/j.ecolecon.2014.02.003

Blas, A., Garrido, A., Willaarts, B., 2018. Food consumption and waste in Spanish households: Water implications within and beyond national borders. Ecol. Indic. 89, 290-300. https://doi.org/10.1016/j.ecolind.2018.01.057

Blas, A., Garrido, A., Willaarts, B.A., 2016. Evaluating the water footprint of the mediterranean and American diets. Water (Switzerland) 8, 1-14. https://doi.org/10.3390/w8100448

Blondel, J., 2006. The "design" of Mediterranean landscapes: A millennial story of humans and ecological systems during the historic period. Hum. Ecol. 34, 713-729. https://doi.org/10.1007/s10745-006-9030-4

Blum, A., 2009. Effective use of water (EUW) and not water-use efficiency (WUE) is the target of crop yield improvement under drought stress. F. Crop. Res. 112, 119-123. https://doi.org/10.1016/j.fcr.2009.03.009

Bonaccio, M., Di Castelnuovo, A., Pounis, G., Costanzo, S., Persichillo, M., Cerletti, C., Donati, M.B., de Gaetano, G., lacoviello, L., 2017. High adherence to the Mediterranean diet is associated with cardiovascular protection in higher but not in lower socioeconomic groups: Prospective findings from the Moli-sani study. Int. 
J. Epidemiol. 46, 1478-1487. https://doi.org/10.1093/IJE/DYX145

Bonaccio, M., lacoviello, L., Gaetano, G. De, 2012. The Mediterranean diet : The reasons for a success. Thromb. Res. 129, 401-404. https://doi.org/10.1016/j.thromres.2011.10.018

Bonny, S.. P.. F.., Gardner, G.. E.., Pethick, D.. W.., Hocquette, J.-F., 2015. What is artificial meat and what does it mean for the future of the meat industry ? Journal of Integrative Agriculture, What Is 'Artificial Meat ' and What Does It Me. J. Integr. Agric. 3119, 255-263.

Boulay, A.-M., Hoekstra, A.Y., Vionnet, S., 2013. Complementarities of Water-Focused Life Cycle Assessment and Water Footprint Assessment. Environ. Sci. Technol. 47, 11926-11927. https://doi.org/10.1021/es403928f

Boulay, A.M., Bare, J., Benini, L., Berger, M., Lathuillière, M.J., Manzardo, A., Margni, M., Motoshita, M., Núñez, M., Pastor, A.V., Ridoutt, B., Oki, T., Worbe, S., Pfister, S., 2018. The WULCA consensus characterization model for water scarcity footprints: assessing impacts of water consumption based on available water remaining (AWARE). Int. J. Life Cycle Assess. 23, 368-378. https://doi.org/10.1007/s11367017-1333-8

Bouwman, A.F., Beusen, A.H.W., Billen, G., 2009. Human alteration of the global nitrogen and phosphorus soil balances for the period 1970-2050. Global Biogeochem. Cycles 23. https://doi.org/10.1029/2009GB003576

Brancoli, P., Rousta, K., Bolton, K., 2017. Life cycle assessment of supermarket food waste. "Resources, Conserv. Recycl. 118, 39-46. https://doi.org/10.1016/j.resconrec.2016.11.024

Brockerhoff, M., Nations, U., 1998. World Urbanization Prospects: The 1996 Revision. Popul. Dev. Rev. 24, 883. https://doi.org/10.2307/2808041

Capone, R., Bilali, H. El, Debs, P., Cardone, G., Driouech, N., 2014. Mediterranean Food Consumption Patterns Sustainability : Setting Up a Common Ground for Future Research and Action. Am. J. Nutr. Food Sci. 1, 37-52. https://doi.org/10.12966/ajnfs.04.04.2014

Capone, R., Iannetta, M., Bilali, H. El, Colonna, N., Debs, P., Dernini, S., Maiani, G., Intorre, F., Polito, A., Turrini, A., Cardone, G., Lorusso, F., Belsanti, V., 2013. A Preliminary Assessment of the Environmental Sustainability of the Current Italian Dietary Pattern: Water Footprint Related to Food Consumption. J. Food Nutr. Res. 1, 59-67. https://doi.org/10.12691/jfnr-1-4-5

Carlsson-Kanyama, A., González, A.D., 2009. Potential contributions of food consumption patterns to climate change. Am. J. Clin. Nutr. 89, 1704S-1709S. https://doi.org/10.3945/ajcn.2009.26736AA.1704S

Carvalho, F.P., 2006. Agriculture, pesticides, food security and food safety. Environ. Sci. Policy 9, 685-692. https://doi.org/10.1016/j.envsci.2006.08.002

Chapagain, A.K., Hoekstra, A.Y., Savenije, H.H.G., 2006. Water saving through international trade of agricultural products 455-468.

Chico, D., Aldaya, M.M., Garrido, A., 2013. A water footprint assessment of a pair of 
jeans: the influence of agricultural policies on the sustainability of consumer products. J. Clean. Prod. 238-248. https://doi.org/10.1016/j.jclepro.2013.06.001

Chico, D., Salmoral, G., Llamas, M.R., Garrido, A., Aldaya, M.M., 2010. The water footprint and virtual water exports of Spanish tomatoes, Papeles de Agua Virtual. Fundación Botín,

Madrid. https://doi.org/http://dx.doi.org/10.1016/j.jclepro.2013.06.001

D’Odorico, P., Carr, J.A., Laio, F., Ridolfi, L., Vandoni, S., 2014. Feeding humanity through global food trade. Earth's Futur. 2, 458-469. https://doi.org/10.1002/2014EF000250

Da Silva, R., Bach-Faig, A., Raidó Quintana, B., Buckland, G., Vaz De Almeida, M.D., SerraMajem, L., 2009. Worldwide variation of adherence to the Mediterranean diet, in 1961-1965 and 2000-2003. Public Health Nutr. 12, 1676-1684. https://doi.org/10.1017/S1368980009990541

Dalin, C., Konar, M., Hanasaki, N., Rodriguez-iturbe, I., 2012. Evolution of the global virtual water trade network. Proc. Natl. Acad. Sci. 109, 8353-8353. https://doi.org/10.1073/pnas.1206123109

Dalin, C., Wada, Y., Kastner, T., Puma, M.J., 2017. Groundwater depletion embedded in international food trade. Nature 543, 700-704. https://doi.org/10.1038/nature21403

Davis, K.F., Gephart, J.A., Emery, K.A., Leach, A.M., Galloway, J.N., D’Odorico, P., 2016. Meeting future food demand with current agricultural resources. Glob. Environ. Chang. 39, 125-132. https://doi.org/10.1016/j.gloenvcha.2016.05.004

De Boer, J., Schösler, H., Aiking, H., 2014. "Meatless days" or "less but better"? Exploring strategies to adapt Western meat consumption to health and sustainability challenges. Appetite 76, 120-128. https://doi.org/10.1016/j.appet.2014.02.002

De Miguel, Á., Hoekstra, A.Y., García-Calvo, E., 2015. Sustainability of the water footprint of the Spanish pork industry. Ecol. Indic. 57, 465-474. https://doi.org/10.1016/j.ecolind.2015.05.023

Demirbas, A., 2009. Political, economic and environmental impacts of biofuels: A review. Appl. Energy 86, S108-S117. https://doi.org/10.1016/j.apenergy.2009.04.036

Dernini, S., Berry, E.M., 2015. Mediterranean Diet: From a Healthy Diet to a Sustainable Dietary Pattern. Front. Nutr. 2. https://doi.org/10.3389/fnut.2015.00015

Donati, M., Menozzi, D., Zighetti, C., Rosi, A., Zinetti, A., Scazzina, F., 2016. Towards a sustainable diet combining economic, environmental and nutritional objectives. Appetite 106, 48-57. https://doi.org/10.1016/j.appet.2016.02.151

Dou, Z., Ferguson, J.D., Galligan, D.T., Kelly, A.M., Finn, S.M., Giegengack, R., 2016. Assessing U.S. food wastage and opportunities for reduction. Glob. Food Sec. 8, 1926. https://doi.org/10.1016/j.gfs.2016.02.001

Duarte, F., Jones, N., Fleskens, L., 2008. Traditional olive orchards on sloping land: Sustainability or abandonment? J. Environ. Manage. 89, 86-98. https://doi.org/10.1016/j.jenvman.2007.05.024 
Dumont, A., Salmoral, G., Llamas, M.R., 2013. The water footprint of a river basin with a special focus on groundwater: The case of Guadalquivir basin ( Spain ), in: VII Congreso Ibérico Sobre Gestión y Planificación Del Agua "Ríos Ibéricos +10 . Mirando Al Futuro Tras 10 Años de DMA". pp. 60-76.

EFBW, 2017. European Federation of Bottled Water (EFBW) [WWW Document]. URL http://www.efbw.org (accessed 9.1.17).

Eitelberg, D.A., van Vliet, J., Verburg, P.H., 2015. A review of global potentially available cropland estimates and their consequences for model-based assessments. Glob. Chang. Biol. 21, 1236-1248. https://doi.org/10.1111/gcb.12733

Engström, R., Carlsson-Kanyama, A., 2004. Food losses in food service institutions Examples from Sweden. Food Policy 29, 203-213. https://doi.org/10.1016/j.foodpol.2004.03.004

Erb, K.-H., Luyssaert, S., Meyfroidt, P., Pongratz, J., Don, A., Kloster, S., Kuemmerle, T., Fetzel, T., Fuchs, R., Herold, M., Haberl, H., Jones, C.D., Marín-Spiotta, E., McCallum, I., Robertson, E., Seufert, V., Fritz, S., Valade, A., Wiltshire, A., Dolman, A.J., 2017. Land management: data availability and process understanding for global change studies. Glob. Chang. Biol. 23, 512-533. https://doi.org/10.1111/gcb.13443

Ercsey-Ravasz, M., Toroczkai, Z., Lakner, Z., Baranyi, J., 2012. Complexity of the international agro-food trade network and its impact on food safety. PLoS One 7, 1-7. https://doi.org/10.1371/journal.pone.0037810

European Commision, 2015. An EU action plan for the circular economy, European Commission. https://doi.org/10.1017/СBO9781107415324.004

European Commission, 2010. Preparatory Study on Food Waste Across EU 27, European Commission. https://doi.org/10.2779/85947

European Parliament, 2012. Avoiding food wastage. Strategies for a more efficient food chain in the EU. https://doi.org/http://www.europarl.europa.eu/sides/getDoc.do?pubRef=//EP//NONSGML+TA+P7-TA-2012-0014+0+DOC+PDF+V0//EN

Ewert, F., Rounsevell, M.D.A., Reginster, I., Metzger, M.J., Leemans, R., 2005. Future scenarios of European agricultural land use. Agric. Ecosyst. Environ. 107, 101-116. https://doi.org/10.1016/j.agee.2004.12.003

FAO, 2017a. The future of food and agriculture - Trends and challenges. Rome. https://doi.org/http://www.fao.org/3/a-i6583e.pdf

FAO, 2017b. The State of Food and Agriculture 2017 - Leveraging Food Systems for Inclusive Rural Transformation. https://doi.org/http://www.fao.org/3/ai7658e.pdf

FAO, 2015. Stadistical Database [WWW Document]. URL http://faostat3.fao.org/home/E (accessed 1.1.15).

FAO, 2010. Sustainable diets and biodiversity, Biodiversity and sustainable diets united against hunger. Rome, Italy. https://doi.org/10.1017/S002081830000607X

FAO, 2001. Food Balance / Food Balance Sheets. A handbook [WWW Document]. URL 
http://faostat3.fao.org

FAO, 1996. Rome Declaration on World Food Security and World Food Summit Plan of Action. World Food Summit 1-37. https://doi.org/10.4337/9780857939388

FAO, IFAD, UNICEF, WFP, WHO, 2018. The State of Food Security and Nutrition in the World 2018. Building climate resilience for food security and nutrition. Rome, Italy. https://doi.org/10.1109/JSTARS.2014.2300145

FAO, IFAD, UNICEF, WFP, WHO, 2017. The State of Food Security and Nutrition in the World, FAO, Rome, Italy.

FAOSTAT, 2017. Statistical Databases [WWW Document]. URL http://faostat.fao.org (accessed 1.4.18).

Fargione, J., Hill, J., Tilman, D., Polasky, S., Hawthorne, P., 2008. Land Clearing and the Biofuel Carbon Debt. Science (80-. ). 319(5867), 1235-1238. https://doi.org/10.1126/science.1152747

FEN, 2018. Federación Española de Nutrición. Valor nuticional alimentos [WWW Document]. https://doi.org/http://www.fen.org.es/mercadoFen/mercadofen_ajus_Ingles.htm I

Fiala, N., 2008. Meeting the demand: An estimation of potential future greenhouse gas emissions from meat production. Ecol. Econ. 67, 412-419. https://doi.org/10.1016/j.ecolecon.2007.12.021

Flachsbarth, I., Willaarts, B., Xie, H., Pitois, G., Mueller, N.D., Ringler, C., Garrido, A., 2015. The role of Latin America's land and water resources for global food security: Environmental trade-offs of future food production pathways. PLoS One 10, 1-24. https://doi.org/10.1371/journal.pone.0116733

Foley, J.A., DeFries, R., Asner, G.P., Barford, C., Bonan, G., Carpenter, S.R., Chapin, F.S., Coe, M.T., Daily, G.C., Gibbs, H.K., Helkowski, J.H., Holloway, T., Howard, E.A., Kucharik, C.J., Monfreda, C., Patz, J.A., Prentice, I.C., Ramankutty, N., Ramankutty, N., Snyder, P.K., 2005. Global consequences of land use. Science (80-. ). 309, 570574.

Foley, J.A., Ramankutty, N., Brauman, K.A., Cassidy, E.S., Gerber, J.S., Johnston, M., Mueller, N.D., O'Connell, C., Ray, D.K., West, P.C., Balzer, C., Bennett, E.M., Carpenter, S.R., Hill, J., Monfreda, C., Polasky, S., Rockström, J., Sheehan, J., Siebert, S., Tilman, D., Zaks, D.P.M., 2011. Solutions for a cultivated planet. Nature 478, 337-342. https://doi.org/10.1038/nature10452

Fundación Dieta Mediterránea, 2018. Fundación Dieta Mediterránea [WWW Document]. URL https://dietamediterranea.com/en/ (accessed 10.22.18).

Fundación Dieta Mediterránea, 2015. Fundación Dieta Mediterránea [WWW Document]. URL https://dietamediterranea.com/category/menus/ (accessed 1.1.16).

Galli, A., Halle, M., Grunewald, N., 2015. Physical limits to resource access and utilisation and their economic implications in Mediterranean economies. Environ. Sci. Policy 51, 125-136. https://doi.org/10.1016/j.envsci.2015.04.002 
Galli, A., Iha, K., Halle, M., El Bilali, H., Grunewald, N., Eaton, D., Capone, R., Debs, P., Bottalico, F., 2017. Mediterranean countries' food consumption and sourcing patterns:An Ecological Footprint viewpoint. Sci. Total Environ. 578, 383-391. https://doi.org/10.1016/j.scitotenv.2016.10.191

Garnett, T., 2014. Three perspectives on sustainable food security: Efficiency, demand restraint, food system transformation. What role for life cycle assessment? J. Clean. Prod. 73, 10-18. https://doi.org/10.1016/j.jclepro.2013.07.045

Garnett, T., 2011. Where are the best opportunities for reducing greenhouse gas emissions in the food system (including the food chain)? Food Policy 37, 463-466. https://doi.org/10.1016/j.foodpol.2012.04.006

Garnett, T., Appleby, M.C., Balmford, A., Bateman, I.J., Benton, T.G., Bloomer, P., Burlingame, B., Dawkins, M., Dolan, L., Fraser, D., Herrero, M., Hoffmann, I., Smith, P., Thornton, P.K., Toulmin, C., Vermeulen, S.J., Godfray, H.C.J., 2013. Sustainable Intensification in Agriculture: Premises and Policies. Sci. Mag. 341, 33-34. https://doi.org/10.1126/science.1234485

Garrido, A., Llamas, M.R., Varela-Ortega, C., Novo, P., Rodríguez-Casado, R., Aldaya, M.M., 2010. Water footprint and virtual water trade in Spain: Policy implications. Springer Science \& Business Media.

Gawlik, B.M., Easton, P., Koop, S., Van Leeuwen, K., Elelman, R., 2017. Urban Water Atlas for Europe. European Commission, Publications Office of the European Union. European Commission, Publications Office of the European Union, Luxembourg. https://doi.org/https://ec.europa.eu/jrc/en/publication/urban-water-atlaseurope

Geissdoerfer, M., Savaget, P., Bocken, N.M.P., Hultink, E.J., 2017. Review: The Circular Economy - A new sustainability paradigm? J. Clean. Prod. 143, 757-768. https://doi.org/10.1016/j.jclepro.2016.12.048.CITATION

Gephart, J., Davis, K.F., Emery, K.A., Leach, A.M., Galloway, J.N., Pace, M.L., 2016. The environmental cost of subsistence : Optimizing diets to minimize footprints. Sci. Total Environ. 553, 120-127.

Gephart, J.A., Davis, K.F., Emery, K.A., Leach, A.M., Galloway, J.N., Pace, M.L., 2016. The environmental cost of subsistence: Optimizing diets to minimize footprints. Sci. Total Environ. 553, 120-127. https://doi.org/10.1016/j.scitotenv.2016.02.050

Gephart, J.A., Pace, M.L., D' Odorico, P., 2014. Freshwater savings from marine protein consumption. Environ. Res. Lett. 9, 069501. https://doi.org/10.1088/17489326/9/6/069501

Gerbens-Leenes, P.., Nonhebel, S., 2002. Consumption patterns and their effects on land required for food. Ecol. Econ. 42, 185-199. https://doi.org/10.1016/S09218009(02)00049-6

Ghisellini, P., Cialani, C., Ulgiati, S., 2016. A review on circular economy: The expected transition to a balanced interplay of environmental and economic systems. J. Clean. Prod. 114, 11-32. https://doi.org/10.1016/j.jclepro.2015.09.007

Gibbs, H.K., Ruesch, A.S., Achard, F., Clayton, M.K., Holmgren, P., Ramankutty, N., Foley, 
J.A., 2010. Tropical forests were the primary sources of new agricultural land in the 1980s and 1990s. Proc. Natl. Acad. Sci. 107, 16732-16737. https://doi.org/10.1073/pnas.0910275107

Gjerris, M., Gaiani, S., 2013. Household food waste in Nordic countries : Estimations and ethical implications. Etikk i praksis. Nord. J. Appl. Ethics 7, 6-23. https://doi.org/10.5324/eip.v7i1.1786

Gobierno de España, 2018. Plan de Acción para la Implementación de la Agenda 2030. Hacia una Estrategia Española de Desarrollo Sostenible.

Godfray, H.C.J., Beddington, J.R., Crute, I.R., Haddad, L., Lawrence, D., Muir, J.F., Pretty, J., Robinson, S., Thomas, S.M., Toulmin, C., 2010. Food Security : The Challenge of feeding 9 billion people. Science (80-. ). 327, 812-818.

Godfray, H.C.J., Garnett, T., 2014. Food security and sustainable intensification. Philos. Trans. R. Soc. B Biol. Sci. 369, 20120273-20120273. https://doi.org/10.1098/rstb.2012.0273

Griggs, D., Stafford-Smith, M., Gaffney, O., Rockström, J., Öhman, M.C., Shyamsundar, P., Steffen, W., Glaser, G., Kanie, N., Noble, I., 2013. Policy: Sustainable development goals for people and planet. Nature 495, 305-307. https://doi.org/10.1038/495305a

Grimm, N.B., Faeth, S.H., Golubiewski, N.E., Redman, C.L., Wu, J., Bai, X., Briggs, J.M., 2008. Global Change and the Ecology of Cities. Science (80-. ). 319, 756-760. https://doi.org/10.1126/science.1150195

Grizzetti, B., Pretato, U., Lassaletta, L., Billen, G., Garnier, J., 2013. The contribution of food waste to global and European nitrogen pollution. Environ. Sci. Policy 33, 186195. https://doi.org/10.1016/j.envsci.2013.05.013

Gustavsson, J., Cederberg, C., Sonesson, U., Robert van Otterdijk, Meybeck, A., 2011. Global food losses and food waste: extent, causes and prevention. Food and Agriculture Organisation of the United Nations (FAO), Rome.

Hall, K.D., Guo, J., Dore, M., Chow, C.C., 2009. The progressive increase of food waste in America and its environmental impact. PLoS One 4, 9-14. https://doi.org/10.1371/journal.pone.0007940

Hallberg, G.R., 1989. Pesticides pollution of groundwater in the humid United States. Agric. Ecosyst. Environ. 26, 299-367. https://doi.org/10.1016/01678809(89)90017-0

Hallström, E., Carlsson-Kanyama, A., Börjesson, P., 2015. Environmental impact of dietary change: A systematic review. J. Clean. Prod. 91, 1-11. https://doi.org/10.1016/j.jclepro.2014.12.008

Hanasaki, N., Inuzuka, T., Kanae, S., Oki, T., 2010. An estimation of global virtual water flow and sources of water withdrawal for major crops and livestock products using a global hydrological model. J. Hydrol. 384, 232-244. https://doi.org/10.1016/j.jhydrol.2009.09.028

Hanjra, M.A., Qureshi, M.E., 2010. Global water crisis and future food security in an era of climate change. Food Policy 35, 365-377. 
https://doi.org/10.1016/j.foodpol.2010.05.006

Haven, J., Rihane, C., Britten, P., Johnson-Bailey, D., Lino, M., Rahavi, E., Ciampo, M., 2015. Healthy Eating on a Budget at ChooseMyPlate.gov. J. Acad. Nutr. Diet. 114, 834-837. https://doi.org/10.1016/j.jand.2014.04.009

Heller, M.C., Keoleian, G.A., 2015. Greenhouse Gas Emission Estimates of U.S. Dietary Choices and Food Loss. J. Ind. Ecol. 19, 391-401. https://doi.org/10.1111/jiec.12174

Herrero, M., Havlik, P., Valin, H., Notenbaert, A., Rufino, M.C., Thornton, P.K., Blummel, M., Weiss, F., Grace, D., Obersteiner, M., 2013. Biomass use, production, feed efficiencies, and greenhouse gas emissions from global livestock systems. Proc. Natl. Acad. Sci. 110, 20888-20893. https://doi.org/10.1073/pnas.1308149110

Hill, J., Nelson, E., Tilman, D., Polasky, S., Tiffany, D., 2006. Environmental, economic, and energetic costs and benefits of biodiesel and ethanol biofuels. Proc. Natl. Acad. Sci. 103, 11206-11210. https://doi.org/10.1073/pnas.0604600103

HISPACOOP, 2012. Estudio sobre el desperdicio de alimentos en los hogares. Minist. Sanidad, Serv. Soc. e Igual. - Inst. Nac. del Consum. 93.

Hoekstra, A.Y., 2016. A critique on the water-scarcity weighted water footprint in LCA. Ecol. Indic. 66, 564-573. https://doi.org/10.1016/j.ecolind.2016.02.026

Hoekstra, A.Y., Chapagain, A.K., 2007. Water footprints of nations : Water use by people as a function of their consumption pattern 35-48. https://doi.org/10.1007/s11269006-9039-x

Hoekstra, A.Y., Chapagain, A.K., Aldaya, M.M., Mekonnen, M.M., 2011. The Water Footprint Assessment Manual, 2011. https://doi.org/https://waterfootprint.org/media/downloads/TheWaterFootprint AssessmentManual_2.pdf

INE, 2016. Instituto Nacional de Estadística [WWW Document]. URL www.ine.es (accessed 6.20.11).

ISO (International Organization for Standardization), 2013. ISO/DIS 14046.2.Environmental management - Water footprint - Principles , requirements and guidelines.

Jacobsen, S.E., Sørensen, M., Pedersen, S.M., Weiner, J., 2013. Feeding the world: Genetically modified crops versus agricultural biodiversity. Agron. Sustain. Dev. 33, 651-662. https://doi.org/10.1007/s13593-013-0138-9

Jalava, M., Guillaume, J.H.A., Kummu, M., Porkka, M., Siebert, S., Varis, O., 2016. Diet change and food loss reduction: What is their combined impact on global water use and scarcity? Earth's Futur. 4, 62-78. https://doi.org/10.1002/2015EF000327

Jalava, M., Kummu, M., Porkka, M., Siebert, S., Varis, O., 2014. Diet change-a solution to reduce water use? Environ. Res. Lett. 9, 074016. https://doi.org/http://iopscience.iop.org/article/10.1088/17489326/9/7/074016/meta

Jefferies, D., Muñoz, I., Hodges, J., King, V.J., Aldaya, M., Ercin, A.E., Milà i Canals, L., 
Hoekstra, A.Y., 2012. Water Footprint and Life Cycle Assessment as approaches to assess potential impacts of products on water consumption. Key learning points from pilot studies on tea and margarine. J. Clean. Prod. 33, 155-166. https://doi.org/10.1016/j.jclepro.2012.04.015

Johnston, J.L., Fanzo, J.C., Bogil, B., 2014. Understanding Sustainable Diets: A Descriptive Analysis of the Determinants and Processes That Influence Diets and Their Impact on Health, Food Security, and Environmental Sustainability. Adv. Nutr 5, 418-429. https://doi.org/10.3945/an.113.005553.418

Jones, T., 2014. The value of food loss in the American Household. Bur. Appl. Res. Anthropol. A Rep. to Tilia Corp. Fr. CA, USA.

Katajajuuri, J.M., Silvennoinen, K., Hartikainen, H., Heikkilä, L., Reinikainen, A., 2014. Food waste in the Finnish food chain. J. Clean. Prod. 73, 322-329. https://doi.org/10.1016/j.jclepro.2013.12.057

Keyzer, M.A., Merbis, M.D., Pavel, I.F.P.W., Van Wesenbeeck, C.F.A., 2005. Diet shifts towards meat and the effects on cereal use: Can we feed the animals in 2030 ? Ecol. Econ. 55, 187-202. https://doi.org/10.1016/j.ecolecon.2004.12.002

Koester, U., 2013. Total and per capita value of food loss in the United States Comments. Food Policy 41, 63-64. https://doi.org/10.1016/j.foodpol.2013.04.003

Konar, M., Dalin, C., Suweis, S., Hanasaki, N., Rinaldo, A., Rodriguez-Iturbe, I., 2011. Water for food: The global virtual water trade network. Water Resour. Res. 47, 117. https://doi.org/10.1029/2010WR010307

Konar, M., Reimer, J.J., Hussein, Z., Hanasaki, N., 2016. The water footprint of staple crop trade under climate and policy scenarios. Environ. Res. Lett. 11, 035006. https://doi.org/10.1088/1748-9326/11/3/035006

Kounina, A., Margni, M., Bayart, J.-B., Boulay, A.-M., Berger, M., Bulle, C., Frischknecht, R., Koehler, A., Milà i Canals, L., Motoshita, M., Núñez, M., Peters, G., Pfister, S., Ridoutt, B., Zelm, R., Verones, F., Humbert, S., 2012. Review of methods addressing freshwater use in life cycle inventory and impact assessment. Int. J. Life Cycle Assess. https://doi.org/10.1007/s11367-012-0519-3

Kummu, M., de Moel, H., Porkka, M., Siebert, S., Varis, O., Ward, P.J., 2012. Lost food, wasted resources: Global food supply chain losses and their impacts on freshwater, cropland, and fertiliser use. Sci. Total Environ. 438, 477-489. https://doi.org/10.1016/j.scitotenv.2012.08.092

Lassaletta, L., Billen, G., Grizzetti, B., Anglade, J., Garnier, J., 2014a. 50 year trends in nitrogen use efficiency of world cropping systems: The relationship between yield and nitrogen input to cropland. Environ. Res. Lett. 9. https://doi.org/10.1088/17489326/9/10/105011

Lassaletta, L., Billen, G., Romero, E., Garnier, J., Aguilera, E., 2014b. How changes in diet and trade patterns have shaped the $\mathrm{N}$ cycle at the national scale: Spain (19612009). Reg. Environ. Chang. 14, 785-797. https://doi.org/10.1007/s10113-0130536-1

Laurance, W.F., Sayer, J., Cassman, K.G., 2014. Agricultural expansion and its impacts on 
tropical nature. Trends Ecol. Evol. 29, 107-116. https://doi.org/10.1016/j.tree.2013.12.001

Leach, A.M., Emery, K.A., Gephart, J., Davis, K.F., Erisman, J.W., Leip, A., Pace, M.L., D’Odorico, P., Carr, J., Noll, L.C., Castner, E., Galloway, J.N., 2016. Environmental impact food labels combining carbon, nitrogen, and water footprints. Food Policy 61, 213-223. https://doi.org/10.1016/j.foodpol.2016.03.006

Leach, A.M., Galloway, J.N., Bleeker, A., Erisman, J.W., Kohn, R., Kitzes, J., 2012. A nitrogen footprint model to help consumers understand their role in nitrogen losses to the environment. Environ. Dev. 1, 40-66. https://doi.org/10.1016/j.envdev.2011.12.005

Licker, R., Johnston, M., Foley, J.A., Barford, C., Kucharik, C.J., Monfreda, C., Ramankutty, N., 2010. Mind the gap: How do climate and agricultural management explain the "yield gap" of croplands around the world? Glob. Ecol. Biogeogr. 19, 769-782. https://doi.org/10.1111/j.1466-8238.2010.00563.x

Liu, J., Lundqvist, J., Weinberg, J., Gustafsson, J., 2013. Food Losses and Waste in China and Their Implication for Water and Land. Environ. Sci. Technol. 47, 10137-10144. https://doi.org/10.1021/es401426b

López-Gunn, E., Willaarts, B., Dumont, A., Niemeyer, I., Martínez-Santos, P., 2012. The concept of water and food security in Spain., in: Water, Agriculture and the Environment in Spain: Can We Square the Circle? pp. 21-34.

Loumou, A., Giourga, C., 2003. Olive groves: "The life and identity of the Mediterranean." Agric. Human Values 20, 87-95. https://doi.org/10.1023/A:1022444005336

Lundqvist, J., Fraiture, C. De, Molden, D., 2008. Saving Water: From Field to Fork Curbing Losses and Wastage in the Food Chain. SIWI Policy Br. 5-29.

Lundqvist, J., Unver, O., 2018. Alternative pathways to food security and nutrition-water predicaments and human behavior Corrected Proof. Water Policy Corrected Proof 1-14. https://doi.org/10.2166/wp.2018.171

Mabhaudhi, T., Chibarabada, T., Modi, A., 2016. Water-Food-Nutrition-Health Nexus: Linking water to improving food, nutrition and health in Sub-Saharan Africa. Int. J. Environ. Res. Public Health. https://doi.org/10.3390/ijerph13010107

Macdiarmid, J.I., Douglas, F., Campbell, J., 2016. Eating like there's no tomorrow: Public awareness of the environmental impact of food and reluctance to eat less meat as part of a sustainable diet. Appetite 96, 487-493. https://doi.org/10.1016/j.appet.2015.10.011

Macdiarmid, J.I., Kyle, J., Horgan, G.W., Loe, J., Fyfe, C., Johnstone, A., McNeill, G., 2012. Sustainable diets for the future: can we contribute to reducing greenhouse gas emissions by eating a healthy diet? Am. J. Clin. Nutr. 96, 632-9. https://doi.org/10.3945/ajcn.112.038729.Two

Machovina, B., Feeley, K.J., Ripple, W.J., 2015. Biodiversity conservation: The key is reducing meat consumption. Sci. Total Environ. 536, 419-431. https://doi.org/10.1016/j.scitotenv.2015.07.022 
Manzardo, A., Mazzi, A., Loss, A., Butler, M., Williamson, A., Scipioni, A., 2016. Lessons learned from the application of different water footprint approaches to compare different food packaging alternatives. J. Clean. Prod. 112, 4657-4666. https://doi.org/10.1016/j.jclepro.2015.08.019

Mariotti, A., Pan, Y., Zeng, N., Alessandri, A., 2015. Long-term climate change in the Mediterranean region in the midst of decadal variability. Clim. Dyn. 44, 1437-1456. https://doi.org/10.1007/s00382-015-2487-3

Marlow, H.J., Hayes, W.K., Soret, S., Carter, R.L., Schwab, E.R., Sabate, J., 2009. Diet and the environment: does what you eat matter? Am. J. Clin. Nutr. 89, 1699-1703. https://doi.org/10.3945/ajcn.2009.26736Z.1

Marlow, H.J., Hayes, W.K., Soret, S., Carter, R.L., Schwab, E.R., Sabaté, J., 2009. Diet and the environment: Does what you eat matter? Am. J. Clin. Nutr. 89. https://doi.org/10.3945/ajcn.2009.26736Z

Matson, P.A., Parton, W.J., Power, A.G., Swift, M.J., 1997. Agricultural intensification and ecosystem properties. Science (80-. ). 277, 504-509.

Mekonnen, M.M., Hoekstra, a. Y., 2011. The green, blue and grey water footprint of crops and derived crop products. Hydrol. Earth Syst. Sci. 15, 1577-1600. https://doi.org/10.5194/hess-15-1577-2011

Mekonnen, M.M., Hoekstra, A.Y., 2012. A Global Assessment of the Water Footprint of Farm Animal Products. Ecosystems 15, 401-415. https://doi.org/10.1007/s10021011-9517-8

Merino, G., Barange, M., Blanchard, J.L., Harle, J., Holmes, R., Allen, I., Allison, E.H., Badjeck, M.C., Dulvy, N.K., Holt, J., Jennings, S., Mullon, C., Rodwell, L.D., 2012. Can marine fisheries and aquaculture meet fish demand from a growing human population in a changing climate? Glob. Environ. Chang. 22, 795-806. https://doi.org/10.1016/j.gloenvcha.2012.03.003

Milà, L., Chapagain, A., Orr, S., Chenoweth, J., Anton, A., Clift, R., 2010. Assessing freshwater use impacts in LCA, part 2 : case study of broccoli production in the UK and Spain 598-607. https://doi.org/10.1007/s11367-010-0187-0

Ministerio de Agricultura Alimentación y Medio Ambiente, 2016a. Consumo, comercialización y distribucion alimentaria: Base de datos de consumo en hogares [WWW Document].

URL http://www.magrama.gob.es/es/alimentacion/temas/consumo-ycomercializacion-y-distribucion-alimentaria/panel-de-consumoalimentario/ultimos-datos/ (accessed 6.20.11).

Ministerio de Agricultura Alimentación y Medio Ambiente, 2016b. Anuario de estadística agraria.

Ministerio de Agricultura Alimentación y Medio Ambiente, 2016c. Encuestas Lácteas [WWW Document]. URL http://www.mapama.gob.es/es/estadistica/temas/estadisticasagrarias/ganaderia/estadistica-industrias-lacteas/estadistica-lactea-anual/ (accessed 6.20.11). 
Ministerio de Agricultura Alimentación y Medio Ambiente, 2015. Spanish Strategy "More food, less waste." Publ. Cat. Spanish Natl. Gov. 60. https://doi.org/10.1017/CBO9781107415324.004

Ministerio de Economía, I. y C., 2016. Datacomex [WWW Document]. https://doi.org/http://datacomex.comercio.es/index.htm

Mondéjar-Jiménez, J.A., Ferrari, G., Secondi, L., Principato, L., 2016. From the table to waste: An exploratory study on behaviour towards food waste of Spanish and Italian youths. J. Clean. Prod. 138, 8-18. https://doi.org/10.1016/j.jclepro.2016.06.018

Monier, V., Shailendra, M., Escalon, V., O'Connor, C., Gibon, T., Anderson, G., Hortense, M., Reisinger, H., 2011. Preparatory Study on Food Waste across EU 27. Eur. Comm. (DG ENV) Dir. C-Industry. 2010. Final Report.

Naska, A., Fouskakis, D., Oikonomou, E., Almeida, M.D.V., Berg, M.A., Gedrich, K., Moreiras, O., Nelson, M., Trygg, K., Turrini, A., Remaut, A.M., Volatier, J.L., Trichopoulou, A., Cueto Eulert, A.P., Pajunen, A., Hirvonen, T., Cuadrado, C., Boned, M.L., Seoane Spiegelberg, P., Maffre, J., Karg, G., Wagner, K., Chloptsios, Y., Foukas, V., Tsiotas, K., Kritsellis, E., Barcherini, S., Martines, S., Mork, E., Lund-Iversen, K., Rodrigues, S., Rimmer, D., Burr, S., 2006. Dietary patterns and their sociodemographic determinants in 10 European countries: Data from the DAFNE databank. Eur. J. Clin. Nutr. https://doi.org/10.1038/sj.ejcn.1602284

Nelson, G.C., Valin, H., Sands, R.D., Havlík, P., Ahammad, H., Deryng, D., Elliott, J., Fujimori, S., Hasegawa, T., Heyhoe, E., Kyle, P., Von Lampe, M., Lotze-Campen, H., Mason d'Croz, D., van Meijl, H., van der Mensbrugghe, D., Müller, C., Popp, A., Robertson, R., Robinson, S., Schmid, E., Schmitz, C., Tabeau, A., Willenbockel, D., 2014. Climate change effects on agriculture: Economic responses to biophysical shocks. Proc. Natl. Acad. Sci. 111, 3274-3279. https://doi.org/10.1073/pnas.1222465110

Ng, M., Fleming, T., Robinson, M., Thomson, B., Graetz, N., Margono, C., Mullany, E.C., Biryukov, S., Alfonso, R., Ali, M.K., Ali, R., Guzman, N.A., Ammar, W., Anwari, P., Banerjee, A., Chowdhury, R., Courville, K.J., Criqui, M.H., Cundiff, D.K., Dabhadkar, K.C., Dandona, L., Davis, A., Hankey, G.J., Harewood, H.C., Havmoeller, R., Hay, S., Hernandez, L., Husseini, A., Idrisov, B.T., Eldin, S., Hassan, A., Kengne, A.P., Khader, Y.S., Khang, Y., Kim, D., Kimokoti, R.W., Logroscino, G., Lotufo, P.A., Lu, Y., Ma, J., Mainoo, N.K., Mensah, G.A., Merriman, T.R., Mokdad, A.H., Nisar, M.I., Ohkubo, T., Oti, S.O., Pedroza, A., Prabhakaran, D., Roy, N., Sampson, U., Stapelberg, N.J.C., Sturua, L., Sykes, B.L., Tobias, M., Tran, B.X., Trasande, L., Toyoshima, H., Vos, T., Wang, C., Wang, X., Weiderpass, E., Werdecker, A., Wright, J.L., Yang, Y.C., Yatsuya, H., 2014. Global, regional, and national prevalence of overweight and obesity in children and adults during 1980-2013 : a systematic analysis for the Global Burden of Disease Study 2013384.

Odegard, I.Y.R., van der Voet, E., 2014. The future of food - Scenarios and the effect on natural resource use in agriculture in 2050. Ecol. Econ. 97, 51-59. https://doi.org/10.1016/j.ecolecon.2013.10.005

Olesen, J.E., Trnka, M., Kersebaum, K.C., Skjelvåg, A.O., Seguin, B., Peltonen-sainio, P., 
Rossi, F., Kozyra, J., Micale, F., 2011. Impacts and adaptation of European crop production systems to climate change. Eur. J. Agron. J. 34, 96-112. https://doi.org/10.1016/j.eja.2010.11.003

Olsen, R.L., Hasan, M.R., 2012. A limited supply of fishmeal: Impact on future increases in global aquaculture production. Trends Food Sci. Technol. 27, 120-128. https://doi.org/10.1016/j.tifs.2012.06.003

Pacetti, T., Lombardi, L., Federici, G., 2015. Water-Energy Nexus: a case of biogas production from energy crops evaluated by Water Footprint and LCA methods. J. Clean. Prod. https://doi.org/10.1016/j.jclepro.2015.03.084

Pahlow, M., Oel, P.R. Van, Mekonnen, M.M., Hoekstra, A.Y., 2015. Science of the Total Environment Increasing pressure on freshwater resources due to terrestrial feed ingredients for aquaculture production 536, 847-857.

Papandreou, C., Mourad, T.A., Jildeh, C., Abdeen, Z., Philalithis, A., Tzanakis, N., 2008. Obesity in Mediterranean region (1997-2007): A systematic review. Obes. Rev. 9, 389-399. https://doi.org/10.1111/j.1467-789X.2007.00466.x

Parfitt, J., Barthel, M., Macnaughton, S., 2010. Food waste within food supply chains: quantification and potential for change to 2050. Philos. Trans. R. Soc. Lond. B. Biol. Sci. 365, 3065-81. https://doi.org/10.1098/rstb.2010.0126

Pekcan, G., Köksal, E., Küçükerdönmez, O., Ozel, H., 2006. Household food wastage in Turkey, FAO. Rome, Italy.

Peschel, A.O., Grebitus, C., Steiner, B., Veeman, M., 2016. How does consumer knowledge affect environmentally sustainable choices? Evidence from a crosscountry latent class analysis of food labels. Appetite 106, 78-91. https://doi.org/10.1016/j.appet.2016.02.162

Pfister, S., Boulay, A.M., Berger, M., Hadjikakou, M., Motoshita, M., Hess, T., Ridoutt, B., Weinzettel, J., Scherer, L., Döll, P., Manzardo, A., Núñez, M., Verones, F., Humbert, S., Buxmann, K., Harding, K., Benini, L., Oki, T., Finkbeiner, M., Henderson, A., 2017. Understanding the LCA and ISO water footprint: A response to Hoekstra (2016) "A critique on the water-scarcity weighted water footprint in LCA." Ecol. Indic. 72, 352-359. https://doi.org/10.1016/j.ecolind.2016.07.051

Pimentel, D., Pimentel, M., 2003. Sustainability of meat-based and plant-based diets and the environment. Am. J. Clin. Nutr. 78, 660S-663S.

Pinstrup-Andersen, P., 2009. Food security: definition and measurement. Food Secur. 1, 5-7. https://doi.org/10.1007/s12571-008-0002-y

Porter, J.R., Xie, L., Challinor, A.J., Cochrane, K., Howden, S.M., Iqbal, M.M., Lobell, D.B., Travasso, M.I., 2014. Food Security and Food Production Systems, in: Climate Change 2014: Impacts, Adaptation, and Vulnerability. Cambridge University Press, pp. 485-533.

Power, J.F., Schepers, J.S., 1989. Nitrate contamination of groundwater in North America. Agric. Ecosyst. Environ. 26, 165-187. https://doi.org/10.1016/01678809(89)90012-1

Quested, T., Ingle, R., Parry, A., 2012. Household Food and Drink Waste in the UK, WRAP. 
https://doi.org/10.1111/j.1467-3010.2011.01924.x

Quested, T.E., Marsh, E., Stunell, D., Parry, A.D., 2013. Spaghetti soup: The complex world of food waste behaviours. Resour. Conserv. Recycl. 79, 43-51. https://doi.org/10.1016/j.resconrec.2013.04.011

Ramankutty, N., Evan, A.T., Monfreda, C., Foley, J.A., 2008. Farming the planet: 1. Geographic distribution of global agricultural lands in the year 2000. Global Biogeochem. Cycles 22, 1-19. https://doi.org/10.1029/2007GB002952

Ramankutty, N., Mehrabi, Z., Waha, K., Jarvis, L., Kremen, C., Herrero, M., Rieseberg, L.H., 2018. Trends in Global Agricultural Land Use: Implications for Environmental Health and Food Security. Annu. Rev. Plant Biol. 69, annurev-arplant-042817040256. https://doi.org/10.1146/annurev-arplant-042817-040256

Rathmann, R., Szklo, A., Schaeffer, R., 2010. Land use competition for production of food and liquid biofuels: An analysis of the arguments in the current debate. Renew. Energy 35, 14-22. https://doi.org/10.1016/j.renene.2009.02.025

REDS, 2018. Red Española para el Desarrollo Sostenible España, 2018.

Reijnders, L., Soret, S., 2003. Quantification of the environmental impact of different dietary. Am J Clin Nutr 78, 664-668.

Renault, D., Wallender, W.W., 2000. Nutritional water productivity and diets. Agric. Water Manag. https://doi.org/10.1016/S0378-3774(99)00107-9

Reutter, B., Lant, P., Lane, J., Reynolds, C., Reynolds, C., 2017. Food waste consequences: Environmentally extended input-output as a framework for analysis. J. Clean. Prod. 153, 506-514. https://doi.org/10.1016/j.jclepro.2016.09.104

Ridoutt, B.G., Juliano, P., Sanguansri, P., Sellahewa, J., 2010. The water footprint of food waste: Case study of fresh mango in Australia. J. Clean. Prod. 18, 1714-1721. https://doi.org/10.1016/j.jclepro.2010.07.011

Rockström, J., Falkenmark, M., Karlberg, L., Hoff, H., Rost, S., Gerten, D., 2009. Future water availability for global food production: The potential of green water for increasing resilience to global change. Water Resour. Res. 45, 1-16. https://doi.org/10.1029/2007WR006767

Rockström, J., Williams, J., Daily, G., Noble, A., Matthews, N., Gordon, L., Wetterstrand, H., DeClerck, F., Shah, M., Steduto, P., de Fraiture, C., Hatibu, N., Unver, O., Bird, J., Sibanda, L., Smith, J., 2017. Sustainable intensification of agriculture for human prosperity and global sustainability. Ambio 46, 4-17. https://doi.org/10.1007/s13280-016-0793-6

Rosenzweig, C., Elliott, J., Deryng, D., Ruane, A.C., Müller, C., Arneth, A., Boote, K.J., Folberth, C., Glotter, M., Khabarov, N., Neumann, K., Piontek, F., Pugh, T.A.M., Schmid, E., Stehfest, E., Yang, H., Jones, J.W., 2014. Assessing agricultural risks of climate change in the 21st century in a global gridded crop model intercomparison. Proc. Natl. Acad. Sci. 111, 3268-3273. https://doi.org/10.1073/pnas.1222463110

Rosi, A., Mena, P., Pellegrini, N., Turroni, S., Neviani, E., Ferrocino, I., Di Cagno, R., Ruini, L., Ciati, R., Angelino, D., Maddock, J., Gobbetti, M., Brighenti, F., Del Rio, D., Scazzina, F., 2017. Environmental impact of omnivorous, ovo-lacto-vegetarian, and 
vegan diet. Sci. Rep. 7, 1-9. https://doi.org/10.1038/s41598-017-06466-8

Royal Society (Great Britain), 2009. Reaping the benefits : science and the sustainable intensification of global agriculture. The Royal Society.

Sáez-Almendros, S., Obrador, B., Bach-Faig, A., Serra-Majem, L., 2013. Environmental footprints of Mediterranean versus Western dietary patterns: beyond the health benefits of the Mediterranean diet. Environ. Heal. 12, 118. https://doi.org/10.1186/1476-069X-12-118

Salmoral, G., Aldaya, M.M., Chico, D., Garrido, A., Llamas, R., 2011. The water footprint of olives and olive oil in Spain. Spanish J. Agric. Res. 9, 1089-1104. https://doi.org/10.5424/sjar/20110904-035-11

Sánchez de Madariaga, I., García López, J., Sisto, R., 2018. Mirando hacia el futuro: ciudades sostenibles. Los objetivos de desarrollo sostenible en 100 ciudades españolas, Red Española para el Desarrollo Sostenible.

Scholz, K., Eriksson, M., Strid, I., 2015. Carbon footprint of supermarket food waste. "Resources, Conserv. Recycl. 94, 56-65. https://doi.org/10.1016/j.resconrec.2014.11.016

SDSN, 2018a. Sustainable Development Solutions Network: Factsheet.

SDSN, 2018b. SDGs Index and Dashboard Report 2018: Global Responsibilites: Implementing the Goals 1-9.

Searchinger, T., Heimlich, R., Houghton, R.A., Dong, F., Elobeid, A., Fabiosa, J., Tokgoz, S., Hayes, D., Yu, T.H., 2008. Use of U.S. croplands for biofuels increases greenhouse gases through emissions from land-use change. Science (80-. ). 319, 1238-1240. https://doi.org/10.1126/science.1151861

Secondi, L., Principato, L., Laureti, T., 2015. Household food waste behaviour in EU-27 countries: A multilevel analysis. Food Policy 56, 25-40. https://doi.org/10.1016/j.foodpol.2015.07.007

Segen, J., 2012. Concise dictionary of modern medicin, Farlex, Inc.

Serra-Majem, L., Ribas, L., Ngo, J., Ortega, R.M., Garcia, A., Perez-Rodrigo, C., Aranceta, J., 2004. Food, youth and the Mediterranean diet in Spain. Development of KIDMED, Mediterranean Diet Quality Index in children and adolescents. Public Heal. Nutr 7, 931-935. https://doi.org/10.1079/PHN2004556

SIWI, 2015. Nine billion consumers and the water crises. Stockholm.

SIWI, IWM, 2004. WATER-MORE NUTRITION PER DROP Towards Sustainable Food Production and Consumption Patterns in a Rapidly Changing World. Stockholm.

Smith, C., McDonald, G., 1998. Assessing the sustainability of agriculture at the planning stage. J. Environ. Manage. 52, 15-37. https://doi.org/10.1006/jema.1997.0162

Smith, M.D., Roheim, C.A., Crowder, L.B., Halpern, B.S., Turnipseed, M., Anderson, J.L., Asche, F., Bourillón, L., Guttormsen, A.G., Khan, A., Liguori, L.A., McNevin, A., O'Connor, M.I., Squires, D., Tyedmers, P., Brownstein, C., Carden, K., Klinger, D.H., Sagarin, R., Selkoe, K.A., 2010. Economics. Sustainability and global seafood. Science 327, 784-6. https://doi.org/10.1126/science.1185345 
Song, G., Li, M., Semakula, H.M., Zhang, S., 2015. Food consumption and waste and the embedded carbon, water and ecological footprints of households in China. Sci. Total Environ. 529, 191-197. https://doi.org/10.1016/j.scitotenv.2015.05.068

Springmann, M., Clark, M., Mason-D'Croz, D., Wiebe, K., Bodirsky, B.L., Lassaletta, L., de Vries, W., Vermeulen, S.J., Herrero, M., Carlson, K.M., Jonell, M., Troell, M., DeClerck, F., Gordon, L.J., Zurayk, R., Scarborough, P., Rayner, M., Loken, B., Fanzo, J., Godfray, H.C.J., Tilman, D., Rockström, J., Willett, W., 2018. Options for keeping the food system within environmental limits. Nature 562, 519-525. https://doi.org/10.1038/s41586-018-0594-0

Stahel, W.R., 2015. Circular Economy. Nature 6-9. https://doi.org/10.1038/531435a

Stancu, V., Haugaard, P., Lähteenmäki, L., 2016. Determinants of consumer food waste behaviour: Two routes to food waste. Appetite 96, 7-17. https://doi.org/10.1016/j.appet.2015.08.025

Stevens, G.A., Singh, G.M., Lu, Y., Danaei, G., Lin, J.K., Finucane, M.M., Bahalim, A.N., Mcintire, R.K., Gutierrez, H.R., Cowan, M., Paciorek, C.J., 2012. National , regional , and global trends in adult overweight and obesity prevalences. Popul. Health Metr. 1-16.

Tester, M., Langridge, P., 2010. Breeding technologies to increase crop production in a changing world. Science (80-. ). 327, 818-822. https://doi.org/10.1126/science.1183700

Thornton, P.K., 2010. Livestock production: recent trends, future prospects. Philos. Trans. R. Soc. B Biol. Sci. 365, 2853-2867. https://doi.org/10.1098/rstb.2010.0134

Tilman, D., Balzer, C., Hill, J., Befort, B.L., 2011. Global food demand and the sustainable intensification of agriculture. Proc. Natl. Acad. Sci. 108, 20260-20264. https://doi.org/10.1073/pnas.1116437108

Tilman, D., Cassman, K.G., Matson, P.A., Naylor, R., Polasky, S., 2002. Agricultural sustainability and intensive production practices. Nature 418, 671-7. https://doi.org/10.1038/nature01014

Tilman, D., Clark, M., 2014. Global diets link environmental sustainability and human health. Nature 515, 518-522. https://doi.org/10.1038/nature13959

Tilman, D., Fargione, J., Wolff, B., Antonio, C.D., Dobson, A., Howarth, R., Schindler, D., Schlesinger, W.H., Simberloff, D., Swackhamer, D., 2001. Forecasting Agriculturally Driven Environmental Change. Am. Assoc. Adv. Sci. 292, 281-284. https://doi.org/10.1126/science.1057544

Tilman, D., Socolow, R.H., Foley, J.A., Hill, J., Larson, E., Lynd, L., Pacala, S., Reilly, J., Searchinger, T., Somerville, C., Williams, R., 2009. Beneficial biofuel - the food, energy, and environment trilemma. Science (80-. ). 325, 270-271. https://doi.org/10.1126/science.1177970

Tom, M.S., Fischbeck, P.S., Hendrickson, C.T., 2016. Energy use, blue water footprint, and greenhouse gas emissions for current food consumption patterns and dietary recommendations in the US. Environ. Syst. Decis. 36, 92-103. https://doi.org/10.1007/s10669-015-9577-y 
Tukker, A., Goldbohm, R.A., De Koning, A., Verheijden, M., Kleijn, R., Wolf, O., PérezDomínguez, I., Rueda-Cantuche, J.M., 2011. Environmental impacts of changes to healthier diets in Europe. Ecol. Econ. 70, 1776-1788. https://doi.org/10.1016/j.ecolecon.2011.05.001

Tur, J.A., Romaguera, D., Pons, A., 2004. Food Consumption Patterns in a Mediterranean Region: Does the Mediterranean Diet Still Exist? Ann. Nutr. Metab. 48, 193-201.

Ulaszewska, M.M., Luzzani, G., Pignatelli, S., Capri, E., 2017. Assessment of diet-related GHG emissions using the environmental hourglass approach for the Mediterranean and new Nordic diets. Sci. Total Environ. 574, 829-836. https://doi.org/10.1016/j.scitotenv.2016.09.039

UNESCO, 2016. Representative list of the intangible cultural heritage of humanity [WWW Document]. URL http://www.unesco.org/culture/ich/en/RL/mediterranean-diet-00884 (accessed 7.1.16).

UNESDA, 2017. European softs drinks industry [WWW Document]. URL http://www.unesda.eu (accessed 9.1.17).

United Nations, 2018. World Urbanization Prospects: The 2018 Revision. https://doi.org/https://population.un.org/wup/Publications/Files/WUP2018KeyFacts.pdf

United Nations, 2017. World Population Prospects The 2017 Revision, Working Paper No. ESA/P/WP/248. https://doi.org/10.1017/СВ09781107415324.004

United Nations, 2015. Transforming our world: The 2030 agenda for Sustainable development.

https://doi.org/https://sustainabledevelopment.un.org/post2015/transformingou rworld

United Nations, n.d. United Nations.Sustainable Development Goals [WWW Document]. www.un.org. URL https://www.un.org/sustainabledevelopment/ (accessed 10.18.18).

USDA, 2015. Choose my plate [WWW Document]. URL http://www.choosemyplate.gov

Van Der Werf, G.R., Morton, D.C., Defries, R.S., Olivier, J.G.J., Kasibhatla, P.S., Jackson, R.B., Collatz, G.J., Randerson, J.T., 2009. CO2 emissions from forest loss. Nat. Geosci. 2, 737-738. https://doi.org/10.1038/ngeo671

Van Dooren, C., Marinussen, M., Blonk, H., Aiking, H., Vellinga, P., 2014. Exploring dietary guidelines based on ecological and nutritional values: $A$ comparison of six dietary patterns. Food Policy 44, 36-46. https://doi.org/10.1016/j.foodpol.2013.11.002

Vanham, D., 2013. The water footprint of Austria for different diets. Water Sci. Technol. 67, 824-830. https://doi.org/10.2166/wst.2012.623

Vanham, D., Bidoglio, G., 2015. A review on the indicator water footprint for the EU28. Ecol. Indic. 26, 61-75. https://doi.org/10.1016/j.ecolind.2012.10.021

Vanham, D., Comero, S., Gawlik, B.M., Bidoglio, G., 2018. The water footprint of different diets within European sub-national geographical entities. Nat. Sustain. 167, 1. 
https://doi.org/10.1038/s41893-018-0133-x

Vanham, D., del Pozo, S., Pekcan, A.G., Keinan-Boker, L., Trichopoulou, A., Gawlik, B.M., 2016a. Water consumption related to different diets in Mediterranean cities. Sci. Total Environ. 573, 96-105. https://doi.org/10.1016/j.scitotenv.2016.08.111

Vanham, D., Gawlik, B.M., Bidoglio, G., 2017. Food consumption and related water resources in Nordic cities. Ecol. Indic. 74, 119-129. https://doi.org/10.1016/j.ecolind.2016.11.019

Vanham, D., Hoekstra, A.Y., Bidoglio, G., 2013a. Potential water saving through changes in European diets. Environ. Int. 61, 45-56. https://doi.org/10.1016/j.envint.2013.09.011

Vanham, D., Mak, T.N., Gawlik, B.M., 2016b. Urban food consumption and associated water resources: The example of Dutch cities. Sci. Total Environ. 565, 232-239. https://doi.org/10.1016/j.scitotenv.2016.04.172

Vanham, D., Mekonnen, M.M., Hoekstra, A.Y., 2013b. The water footprint of the EU for different diets. Ecol. Indic. 32, 1-8. https://doi.org/10.1016/j.ecolind.2013.02.020

Varela-Moreiras, G., Ávila, J.M., Cuadrado, C., del Pozo, S., Ruiz, E., Moreiras, O., 2010. Evaluation of food consumption and dietary patterns in Spain by the Food Consumption Survey: Updated information. Eur. J. Clin. Nutr. 64, S37-S43. https://doi.org/10.1038/ejcn.2010.208

Varela, G., Rodríguez, D.G., Moreiras, O., 1971. La nutrición de los españoles: diagnóstico y recomendaciones. Publicaciones La Esc. Nac. Adm. Pública.

Venkat, K., 2012. The climate change and economic impacts of food waste in the United States. Int. J. Food Syst. Dyn. 2, 431-446.

Vermeulen, S.J., Campbell, B.M., Ingram, J.S.I., 2012. Climate Change and Food Systems. Annu. Rev. Environ. Resour. 37, 195-222. https://doi.org/10.1146/annurevenviron-020411-130608

Vieux, F., Darmon, N., Touazi, D., Soler, L.G., 2012. Greenhouse gas emissions of selfselected individual diets in France: Changing the diet structure or consuming less? Ecol. Econ. 75, 91-101. https://doi.org/10.1016/j.ecolecon.2012.01.003

Vinet, L., Zhedanov, A., 2010. A "missing" family of classical orthogonal polynomials. Gen. Assem. 70 Sess. 16301, 1-35. https://doi.org/10.1088/1751$8113 / 44 / 8 / 085201$

Visschers, V.H.M., Wickli, N., Siegrist, M., 2016. Sorting out food waste behaviour: A survey on the motivators and barriers of self-reported amounts of food waste in households. J. Environ. Psychol. 45, 66-78. https://doi.org/10.1016/j.jenvp.2015.11.007

Wenhold, F., Annandale, J., Faber, M., Hart, T., 2012. Water Use and Nutrient Content of Crop and Animal Food Products for Improved Household Food Security: A Scoping Study Report to the WATER RESEARCH COMMISSION.

Westhoek, H., 2014. Food choices, health and environment: Effects of cutting Europe's meat and dairy intake. Glob. Environ. Chang. 26, 196-205. 
https://doi.org/10.1016/j.gloenvcha.2014.02.004

WHO, 2015. Healthy diet; fact sheet 394. World Heal. Organitation.

WHO, 2013. Nutrition, Physical Activity and Obesity: Spain.

WHO, FAO, 2003. Diet, nutrition and the prevention of chronic diseases. Geneve.

Willaarts, B., Niemeyer, I., Garrido, A., 2011. Land and Water Requirements for Soybean Cultivation in Brazil: Environmental Consequences of Food Production and Trade, Journal of Chemical Information and Modeling. https://doi.org/10.1017/СB09781107415324.004

Willett, W.C., Sacks, F., Trichopoulou, A., Drescher, G., Ferro-Luzzi, A., Helsing, E., Trichopoulos, D., 1995. Mediterranean diet pyramid: a cultural model for healthy eating. Am. J. Clin. Nutr. 61, 1402S-1406S.

World Bank, 2015. Future of Food: Shaping a climate-Smart Global Food System 1-32.

WPTC, 2016. World Processing Tomato Council [WWW Document]. URL www.wptc.to (accessed 6.20.11).

WRAP, 2009. Household Food and Drink Waste in the UK. Banbury, UK.

Wriedt, G., Velde, M. Van Der, Aloe, A., Bouraoui, F., 2009. Estimating irrigation water requirements in Europe. J. Hydrol. 373, 527-544. https://doi.org/10.1016/j.jhydrol.2009.05.018

Yang, C., Cui, X., 2014. Global changes and drivers of the water footprint of food consumption: A historical analysis. Water (Switzerland) 6, 1435-1452. https://doi.org/10.3390/w6051435

Yang, H., Wang, L., Abbaspour, K.C., Zehnder, A.J.B., 2006. Virtual water trade: an assessment of water use efficiency in the international food trade. Hydrol. Earth Syst. Sci. Discuss. 443-454. 
ANNEXES 


\section{Annex I. Alternatives to deVelop sustainable agricultural growth: PRODUction ORIENTED MEASURES.}

As the World Bank (2015, p.4) described in their report about future of food and climatesmart global food systems: "Meeting the rising demand for food and ending hunger and food insecurity requires a climate-smart food system that improves agricultural productivity, has greater resilience to climate change and lowers greenhouse gas emissions".

That is, a set of measures and non-mutually exclusive solutions to, on the one hand, produce more food in the world, but on the other, produce less harm to the environment and mitigate the effects of climate change.

All possible measures within the sustainable intensification concept (as can be seen in Chapter 1 ) are possible solutions to the food and feeding crisis. But the sustainable intensification approach has been criticized widely because of its focus on production and the contradiction within their terms (Garnett et al., 2013). For these authors, sustainable intensification it is a new and evolving concept with four premises: the need to increase production, no more land extensification, taking into account also food security at a focus point, and not specify how the goal or the different agricultural techniques must be done. For Foley et al. (2011), to achieve a double food production with a decrease in environmental impacts, strategies, as stopping agricultural expansion, closing yield gaps, increasing cropping efficiency, or shifting diets and reducing waste should be put into practice.

On the other hand, for Tilman et al. (2011), the key point to achieve sustainable intensification will be technology adaptation and transfer, as well as the soil fertility improvement, providing greater yields in non-developed nations. For Godfray and Garnett (2014), the implementation of sustainable intensification will need to be built among all the stakeholders within the food chain. Moreover, different agronomic practices effects on the environment can be very complex, needing a temporal and spatial scale of measurement (Godfray et al., 2010).

Moreover, next, all the alternatives to develop sustainable agricultural growth with a production oriented view, all fully described with a little literature review of them: 


\section{A) Arable land expansion}

The first option in mind to produce and provide more food is an arable land expansion. Extending worldwide' croplands is a thinkable option, but not without many issues and detractors. At present, approximately 15 million $\mathrm{km}^{2}$ (12\% of the global terrestrial icefree surface) is currently used as cropland, of which 1.4 million $\mathrm{km}^{2}$ are permanent crops, including perennial and woody vegetation as fruit trees or vineyards (Erb et al., 2017; FAOSTAT, 2017). Grazing and mowing harvest activities are the ones with the most spatially extensive worldwide land management, covering 28-56 million $\mathrm{km}^{2}$ (21-40\% of the terrestrial ice-free surface intensity) (Erb et al., 2017). The livestock sector occupies $30 \%$ of the world's ice-free surface and contributes to around $40 \%$ of global agricultural gross domestic product (Herrero et al., 2013).

Therefore, one's nowadays-big question is if crop, grazing and pasturelands could increase this extension in the short and medium-term future without implicit environmental problems. On one hand, global footprint of agriculture is already massive with a cropland area as the size of South America and grazing lands as the size of Africa (Foley et al., 2005; Laurance et al., 2014), but in the other hand arable land extension could be a solution for future food shortages.

"Extensification" is the term that some authors use (Godfray and Garnett, 2014), in order to define the action of bringing more land into agriculture. These authors also reported the possibility of arable land expansion as a response to future' world food security, though it usually increases GHG emissions into the atmosphere and produces significant harm to the environment.

According to Laurance et al., (2014) major expansion and intensification during next years is going to occur (especially tropical agriculture in Sub-Saharan Africa and South America) with a subsequent rapid loss and alteration of tropical forests, woodlands, and semi-arid environments. Some other authors (Flachsbarth et al., 2015; Foley et al., 2011, 2005; Tilman et al., 2001) also have reported the negative effects that agriculture expansion would have on the biodiversity, the carbon storage and important in the environmental services.

Moreover, reducing production losses and improving yields from existing farmlands, would be enough in the future to offset the potential food production that could be lost by stopping and decreasing deforestation (Foley et al., 2011). 


\section{B) Closing the "Yield Gap" and "Intensification"}

Increasing food production without agricultural expansion implies that agricultural production in existing lands must increase, being the best places those ones where yields are currently below average (Foley et al., 2011). Yield gap can be defined as "the difference between crop yields observed at any given location and the crop's potential yield at the same location given current agricultural practices and technologies" (Foley et al., 2011, p. 3).

So greater yields can be obtained anywhere, but always depending on the capacity of farmers' to the access and use of inputs, biodiversity, technology, knowledge and efficient management (Godfray et al., 2010). According to these authors, significantly more food can be produced with current crops, livestock and land, but only if new methods are found to close worldwide' yield gaps, and always with an associated potential risk of increasing environmental impacts. The analysis of Foley et al. (2011), shows that bringing yields to within $95 \%$ of their potential for 16 important food and feed crops could add an increase of $58 \%$ in new crop production ( 2.3 billion tones). These opportunities, according to these last authors, can be very significant in many parts of Africa, Latin America and Eastern Europe, but again with high risks to cause major environmental degradation.

For Licker et al. (2010), society needs to develop more sustainable high-yielding cropping practices, because, with the conventional ones, more chemical, nutrient and water inputs will be needed to bring crop yields up to their climatic potential, affecting in a very significant way ecosystem goods, services and human welfare. The study by Tilman et al., (2011) taking into account climate and soil's effects on crop yields, points out that agricultural "intensification" through technology and the improvement of soil fertility in poorest nations could reduce this yield gap.

This other term, "intensification", is another solution in a very close relation to closing the yield gap one. It is a wider term, though implicates all crops in all agricultural lands worldwide. It can be defined as increasing productivity of existing agricultural footprint, or in other words, increasing yields (from a single crop or through increasing crop frequency) within the same area, usually as opposed to "extensification" (Godfray and Garnett, 2014). For Garnett et al. (2013), in some areas yield increase will be completely compatible with environmental improvements, but not in others, meaning that an overall increase in production does not necessarily mean that yields should increase everywhere at any cost. Estimations talk about lower crop yields increase in developed countries in comparison with developing ones because many crops have been approaching their yield ceilings during last decade's in these countries (Tilman et al., 2011). But yet there are disagreements among experts about theoretical limits for all the crops (and livestock rearing) maximum yields under different conditions (Godfray et al., 2010). 


\section{C) Aquaculture}

Seafood (i.e. fish and shellfish harvested from capture fisheries and aquaculture production in marine or different freshwater environments) contribute at least to $15 \%$ of average animal protein consumption in the world, feeding up to 2.9 billion people (Smith et al., 2010). According to these authors, global animal aquaculture production occurs mostly in developing countries (92\%), of which $31 \%$ is from small Chinese fish farms for domestic consumption.

The global farming of seafood has been the fastest growing food-producing sector in the last decades, becoming an important industry in many countries (Olsen and Hasan, 2012), and being sufficiently profitable to permit strong growth (Godfray et al., 2010). Because of economic development and population expansion all over the world, future demand for fish products will increase (Merino et al., 2012; Olsen and Hasan, 2012).

So, can fish production be an alternative to help to feed the growing population? Can this alternative help fight against environmental impacts?

For Godfray et al.(2010), technical advances in hatchery systems, feeds and feed-delivery systems, disease management, better stock selection, larger- scale production technologies, aquaculture in open seas, larger inland water bodies, a wider range of species and production options or cheaper feed substrates could improve aquaculture in the future. On the other hand, these authors also alert that aquaculture may cause harm to the environment. In the same line, Merino et al. (2012), concluded that fish consumption per capita can only be maintained (or increased) in the future if aquaculture makes an increasing contribution to the volume and stability of global fish supplies. They added that it could be only possible if fish resources are managed sustainably and the animal feeds industry reduces its reliance on wild fish.

\section{D) Promoting resources management efficiency}

An efficient management of all recourses and inputs used to grow crops (such as water, nutrients or soil fertility) could also help to increase global crop production and yields. Without the use of synthetic fertilizers, especially industrial nitrogen ones, world food production could not have increased at the rate it did it, and more natural ecosystems would have been converted into agriculture (Tilman et al., 2002). However, also according to these authors, a big proportion of applied nitrogen fertilizers and a smaller portion of the applied phosphorus ones are lost from agricultural fields.

For some other authors (Lassaletta et al., 2014a), nowadays more than half of the nitrogen added to croplands is lost to the environment, producing not only resource losses but environmental damages such us the production of threats to air, water, soil and biodiversity, and generating an increase in GHG emissions. 
Moreover, there are some parts of the world with a real low nutrient use efficiency in their croplands, while others (China, Northern India, USA or Western Europe) have large share volumes of nutrients excess (Foley et al., 2011). Exploitation and understanding of bio-fertilizers management have become also very significant in the agricultural sector due to their potential role in food safety and sustainable crop production, in comparison with inorganic chemical ones (Bhardwaj et al., 2014). Practices that enhance nutrient use efficiency and eco-friendly management would be essential to decrease such losses.

About water use, during the Green Revolution, irrigated lands accounted for a large share of yield rise, but now if water use efficiency is not increased in the next years more irrigation will be required to continue increasing crop production (Tilman et al., 2002). Water-use efficiency is often considered an important determinant of yield under stress (Blum, 2009). According to Blum, an effective use of water (i.e., maximal soil moisture capture for transpiration with reduced non-stomatal transpiration and minimal water loss by soil evaporation) is a major target for yield improvement in water-limited environments.

Not only nutrient and water use efficiency have a key role regarding higher crop yields, but also maintaining soil fertility or an efficient disease and pest control management. Practices such as crop rotations, intercropping or agroforestry would help to increase nutrient, fertility, water or pest control in sustainable ways and obtain major productions.

\section{E) Biotechnology}

The use of biotechnology in agriculture, and how it can help to increase crop yields and production have been widely discussed, especially regarding genetically modified organisms (GMOs) crops. Many authors and professionals consider that GMO crops would be essential in order to achieve major agricultural production with lower impacts to the environment, improving at the end global food security (Carvalho, 2006; Tester and Langridge, 2010).

For Tester and Langridge, (2010), new technologies must be developed in the future to accelerate breeding through improving genotyping and phenotyping methods and by increasing the available genetic diversity, especially in developing countries. In this line, Carvalho, (2006) argued that new techniques, including GMOs resistant to pests, could halt the massive spread of agrochemicals in agriculture fields.

For Godfray et al., (2010) during these upcoming decades there will be examples of current and potential future applications of GMO technology, that would be easily applied to develop crop varieties to yield more. Nevertheless, these authors also highlighted the fact that an important number of particular environmental and food safety issues will need to be addressed in order to have a public and wide acceptance of biotechnology. For Godfray and Garnett, (2014), this actual emphasis of GMO uses in 
agriculture, both by its opponents and supporters, exaggerate its importance as an issue, because GMO tool is one of many in a "well-stocked toolbox".

On the other hand for some other authors, the use of GMO crops and biotechnology are not the solution to feed the world in the near future (Altieri and Rosset, 1999; Jacobsen et al., 2013). An objective review made up by Jacobsen et al., (2013), places GMO crops far down the list of potential solutions in the next decades. For these authors, favoring biodiversity does not exclude any future biotechnological contributions, but the other way around, favoring biotechnology will threat future worldwide biodiversity resources. Moreover, for Altieri and Rosset, (1999), GM crops could lead to many and serious environmental risks and they are not being designed to increase yields or for poor small farmers addition.

The use of biotechnology has been very controversial within last decades. Nowadays there exists a big public, social, and scientific unacceptance of this type of technology, so many other options are now in a more probable leading role in contrast to biotechnology uses ones.

\section{F) Crop allocation for animal feeding}

Croplands used for non direct human consumption practices (animal feeding, biofuels...) have been also in a focus point within last decades. Some voices alert about the loss of good arable and farming lands for these purposes, taking into account the food crisis that would come in next years.

About $36 \%$ of world cereal's consumption goes to feed animals to livestock production, being the larger share of it coarse grains (Alexandratos and Bruinsma, 2012). According to these authors, these values will be higher in the next years due to the meat consumption 'increase projected by 2050, especially for coarse grains and oilseeds productions. Similar values were reported by Foley et al., (2011), pointing out that together; croplands used for animal feed (around 350 million hectares) and pasturegrazing ones (around 3.4 billion hectares), use $75 \%$ of the world's agricultural land. If high crop yield potential lands that are now used to feed livestock production were used for direct human consumption, more people could be supported from the same amount of land (Godfray et al., 2010).

On the other hand, it can be very simplistic just to say that meat consumption is unsustainable or bad because of the use of cropland waste (Godfray et al., 2010), because as the authors remarked, many grasslands used to feed animals cannot be turned into arable crop lands. 


\section{G) Croplands for biofuels}

Many croplands are actually used also for the production of biofuels. Alexandratos and Bruinsma, (2012), estimated the quantities of the main crops projected to be used as biofuels for years 2030 and 2050 as can be seen in Table A1.5.1

Table A1.5.1. Worldwide use of crops for biofuels' production, in 2005, and the 2030 and 2050 projection. Source: (Alexandratos and Bruinsma, 2012)

\begin{tabular}{lllll}
\hline & & 2005 & 2030 & 2050 \\
\hline Cereals & Million tones & 65 & 182 & 182 \\
Cereals & \% total use & 3.2 & 6.7 & 6.1 \\
Vegetable oils & Million tones & 7 & 29 & 29 \\
Vegetable oils & \% total use & 4.8 & 12.6 & 10.3 \\
Sugar (equiv. sugar cane) & Million tones & 28 & 81 & 81 \\
Sugar (equiv. sugar cane) & \% total use & 15.1 & 27.4 & 24.3 \\
Cassava (fresh) & Million tones & 1 & 8 & 8 \\
Cassava & \% total use & 0.4 & 2.3 & 1.8 \\
\hline
\end{tabular}

During the last decade, many authors pointed out the environmental benefits of using biofuels in substitution of fossil ones, as Demirbas (2009) and Hill et al., 2006) among others. On the other hand, there have been some voices against using croplands to produce them, mainly because of environmental issues and land competences. The political, economic and environmental review of biofuels impacts made by Demirbas (2009) concluded that biodiesel is an environmentally friendly alternative. They also highlighted that all biofuels are becoming more attractive because of their lower GHG emissions into the atmosphere, reducing imported petroleum and revitalizing the economy by increasing demand and prices for these agricultural products.

More in this line, studies like the one by Hill et al.(2006), concluded that subsidies for biofuels production are necessary in order to promote fuels with many environmental advantages, especially when they are produced with low-input biomass grown on agriculturally marginal land or from waste biomass.

The discussion about whether using or not marginal croplands have been widely discussed within the last decade. A review made up by Rathmann et al. (2010), about land use and competition for biofuels production pointed out that agro-energy has altered the land use dynamic, shifting crop areas traditionally used for human food over to produce biofuels, contributing in the short run to raise food prices. In another review by Eitelberg et al., (2015) they outlined that biofuel production can be also produced in more marginal areas where most food crops cannot provide profitable yields. 
Moreover, Tilman et al. (2009), pointed out also the idea that biofuels can be produced with little or no competition with food production, with perennial plants grown on abandoned lands, crop and forests residues, or even by municipal or industry wastes.

Fargione et al., (2008) also concluded that converting rainforests, savannas, or grasslands to produce biofuels in Brazil, Southeast Asia, and the United States emitted much more $\mathrm{CO} 2$ emissions than using fossil fuels, whereas if biofuels made from waste biomass or from abandoned agricultural lands would be able to offer immediate GHG lower emissions. In the same line, Searchinger et al.(2008) also highlighted that using cornbased ethanol in the USA nearly doubles greenhouse emissions over 30 years and increases greenhouse gases for 167 years, emphasizing the value of using waste products for biofuels production.

\section{H) Animal breeding and intensification}

Is it possible, as in crop production, developing high technology breeding in order to increase livestock production? Have we reached a livestock production maximum yield? Or do we have a similar "yield gap" as in crops?

Intensification in livestock production, i.e. animal breeding, is very controversial nowadays, and usually implies little consideration for animal welfare where animals are kept in artificial environments (Godfray and Garnett, 2014). For these authors, it is possible in less-developed countries to increase production through progress in breeding, feed matching and veterinary aspects, while animal welfare will also improve. Animal breeding can be used in the production of cloned animals resistant to diseases or to increase the efficiency of meat production (Godfray et al., 2010). Future of livestock production will be determinate by competition for land and water, but developments in breeding and animal health will contribute to increase its potential production and efficiency (Thornton, 2010).

Moreover, nowadays artificial meats, in vitro ones or meat from genetically modified organisms are not sufficiently produced, but maybe in some years the technology for these meats may become sufficiently developed to enter the market (Bonny et al., 2015) and help to provide more food. For Godfray and Garnett (2014), artificial meat in the future can be similar in taste as the current one, but with many interrogations about its ethics, sustainability or social aspects. 


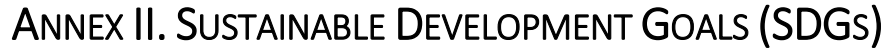

The set of SDGs were born at the United Nations Conference on Sustainable Development in Rio de Janeiro in 2012, in order to summit governments to continue the previous Millennium Development Goals (MDGs) after their 2015 deadline (Griggs et al., 2013). As the MDGs era came to a conclusion with the end of the year 2015, world leaders adopted these goals in the 2030 Agenda for Sustainable Development (Vinet and Zhedanov, 2010).

The objective of this new set of universal goals, as can be seen in Figure A.1, is to produce a new agenda that meets the urgent environmental, political and economic challenges facing our world (United Nations, 2018).

By this way, the international community committed itself to end hunger and poverty and achieve some solutions to make agriculture sustainable, securing health and work for all, reducing inequality, and making economic growth inclusive among others (FAO, 2017b).

However, new solutions, at political, social, environmental, and scientific levels have to be managed and produced in order to achieve all these set of goals. Therefoe, to achieve the triple goal of higher agricultural productivity, increased resilience to climate change and lower total emissions, there is a growing spectrum of interventions, with different options of policies, practices and innovations (World Bank, 2015).

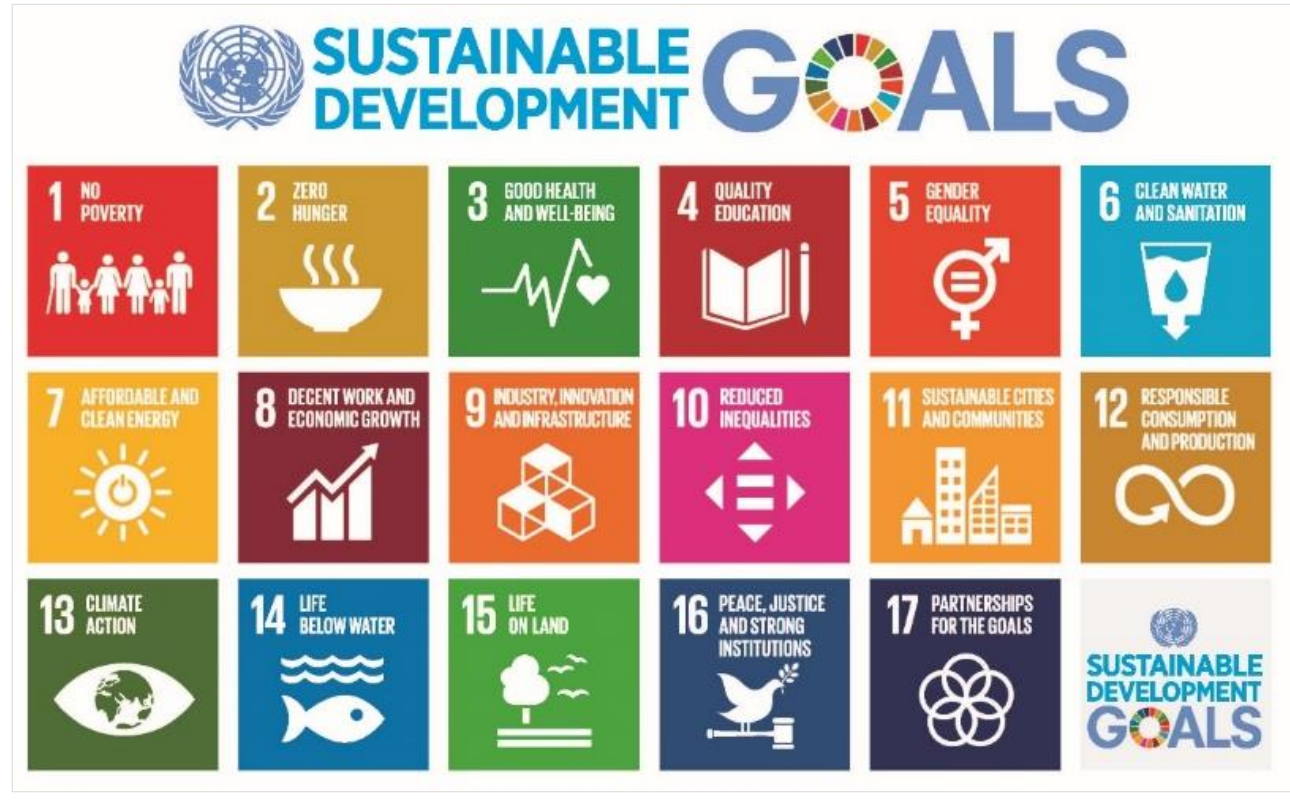

Figure A.1. The Sustainable Development Goals in the 2030 agenda of the United Nations. Source: www. /www.un.org (United Nations, n.d.) 
"The new Sustainable Development Goals to end global poverty and hunger by 2030 offer a major opportunity to place the need for a climate-smart food system at the front and center of the development agenda and debate. This paper calls on the development community, scientists, investors, and civil society to rally behind governments and farmers to support integrated approaches and overcome barriers to adoption of CSA" (World Bank, 2015, p. 4).

The Sustainable Development Goals in the 2030 agenda of the United Nations (2015, p. 14) are:

- Goal 1. End poverty in all its forms everywhere

- Goal 2. End hunger, achieve food security and improved nutrition and promote sustainable agriculture

- Goal 3. Ensure healthy lives and promote well-being for all at all ages

- Goal 4. Ensure inclusive and equitable quality education and promote lifelong learning opportunities for all

- Goal 5. Achieve gender equality and empower all women and girls

- Goal 6. Ensure availability and sustainable management of water and sanitation for all

- Goal 7 Ensure access to affordable, reliable, sustainable and modern energy for all

- Goal 8. Promote sustained, inclusive and sustainable economic growth, full and productive employment and decent work for all

- Goal 9. Build resilient infrastructure, promote inclusive and sustainable industrialization and foster innovation

- Goal 10. Reduce inequality within and among countries

- Goal 11. Make cities and human settlements inclusive, safe, resilient and sustainable

- Goal 12. Ensure sustainable consumption and production patterns

- Goal 13. Take urgent action to combat climate change and its impacts*

- Goal 14. Conserve and sustainably use the oceans, seas and marine resources for sustainable development 
- Goal 15. Protect, restore and promote sustainable use of terrestrial ecosystems, sustainably manage forests, combat desertification, and halt and reverse land degradation and halt biodiversity loss

- Goal 16. Promote peaceful and inclusive societies for sustainable development, provide access to justice for all and build effective, accountable and inclusive institutions at all levels

- Goal 17. Strengthen the means of implementation and revitalize the Global Partnership for Sustainable Development 


\section{ANNEX III. SDG 12 TARGETS}

Table A3.5.2. Targets of Goal 12. Ensure sustainable consumption and production patterns. Source: (Vinet and Zhedanov, 2010, pp. 26-27).

\begin{tabular}{|c|c|}
\hline TARGET & $\begin{aligned} \text { DESCRIPTION } \\
\end{aligned}$ \\
\hline 1 & $\begin{array}{l}\text { Implement the 10JYear Framework of Programs on Sustainable Consumption and } \\
\text { Production Patterns, all countries taking action, with developed countries taking } \\
\text { the lead, taking into account the development and capabilities of developing } \\
\text { countries }\end{array}$ \\
\hline 2 & $\begin{array}{l}\text { By 2030, achieve the sustainable management and efficient use of natural } \\
\text { resources }\end{array}$ \\
\hline 3 & $\begin{array}{l}\text { By } 2030 \text {, halve per capita global food waste at the retail and consumer levels and } \\
\text { reduce food losses along production and supply chains, including postharvest } \\
\text { losses }\end{array}$ \\
\hline 4 & $\begin{array}{l}\text { By 2020, achieve the environmentally sound management of chemicals and all } \\
\text { wastes throughout their life cycle, in accordance with agreed international } \\
\text { frameworks, and significantly reduce their release to air, water and soil in order to } \\
\text { minimize their adverse impacts on human health and the environment }\end{array}$ \\
\hline 5 & $\begin{array}{l}\text { By 2030, substantially reduce waste generation through prevention, reduction, } \\
\text { recycling and reuse }\end{array}$ \\
\hline 6 & $\begin{array}{l}\text { Encourage companies, especially large and transnational companies, to adopt } \\
\text { sustainable practices and to integrate sustainability information into their } \\
\text { reporting cycle }\end{array}$ \\
\hline 7 & $\begin{array}{l}\text { Promote public procurement practices that are sustainable, in accordance with } \\
\text { national policies and priorities }\end{array}$ \\
\hline 8 & $\begin{array}{l}\text { By 2030, ensure that people everywhere have the relevant information and } \\
\text { awareness for sustainable development and lifestyles in harmony with nature }\end{array}$ \\
\hline$A$ & $\begin{array}{l}\text { Support developing countries to strengthen their scientific and technological } \\
\text { capacity to move towards more sustainable patterns of consumption and } \\
\text { production }\end{array}$ \\
\hline B & $\begin{array}{l}\text { Develop and implement tools to monitor sustainable development impacts for } \\
\text { sustainable tourism that creates jobs and promotes local culture and products }\end{array}$ \\
\hline$C$ & $\begin{array}{l}\text { Rationalize inefficient fossil fuel subsidies that encourage wasteful consumption } \\
\text { by removing market distortions, in accordance with national circumstances, } \\
\text { including by restructuring taxation and phasing out those harmful subsidies, where } \\
\text { they exist, to reflect their environmental impacts, taking fully into account the } \\
\text { specific needs and conditions of developing countries and minimizing the possible } \\
\text { adverse impacts on their development in a manner that protects the poor and the } \\
\text { affected communities }\end{array}$ \\
\hline
\end{tabular}


Table A4.5.3. Winter recommended menu of the Mediterranean Diet, with all dishes and ingredients for breakfast, morning-snack, lunch and dinner from Monday to Sunday. Source: own elaboration using the food guidelines elaborated by the Mediterranean Diet Foundation (Fundación Dieta Mediterránea, 2015).

\begin{tabular}{|c|c|c|c|c|c|c|c|}
\hline \multicolumn{8}{|c|}{ WINTER MENU } \\
\hline & MONDAY & TUESDAY & WEDNESDAY & THURSDAY & FRIDAY & SATURDAY & SUNDAY \\
\hline BREAKFAST & $\begin{array}{c}\text { Milk. } \\
\text { Walnuts and } \\
\text { anise cake. } \\
\text { Pear }\end{array}$ & $\begin{array}{l}\text { Coffee with } \\
\text { milk. } \\
\text { Whole } \\
\text { grains }\end{array}$ & $\begin{array}{l}\text { Infusion. } \\
\text { Serrano ham } \\
\text { with Olive } \\
\text { oil bocadillo }\end{array}$ & $\begin{array}{l}\text { Coffee with } \\
\text { milk. Bread } \\
\text { with } \\
\text { strawberry } \\
\text { jam }\end{array}$ & $\begin{array}{l}\text { Milk with } \\
\text { chocolate } \\
\text { powder. } \\
\text { Homemade } \\
\text { muffins }\end{array}$ & $\begin{array}{l}\text { Milk. Bread } \\
\text { with olive } \\
\text { oil, garlic } \\
\text { and } \\
\text { oregano. } \\
\text { Pineapple }\end{array}$ & $\begin{array}{l}\text { Coffee with } \\
\text { milk. } \\
\text { Homemade } \\
\text { ensaimada. } \\
\text { Mandarins }\end{array}$ \\
\hline $\begin{array}{l}\text { MORNING } \\
\text { SNACK }\end{array}$ & $\begin{array}{l}\text { Grapefruit } \\
\text { with honey }\end{array}$ & $\begin{array}{l}\text { Bread with } \\
\text { fresh } \\
\text { cheese and } \\
\text { olive oil. } \\
\text { Natural } \\
\text { lemon } \\
\text { juice. }\end{array}$ & $\begin{array}{c}\text { Coffee with } \\
\text { milk. } \\
\text { Vegetal } \\
\text { bocadillo. }\end{array}$ & Nuts & $\begin{array}{c}\text { Tuna } \\
\text { bocadillo. } \\
\text { Natural } \\
\text { Apple juice. }\end{array}$ & Mussels. & $\begin{array}{c}\text { Fresh cheese } \\
\text { with } \\
\text { pepper and } \\
\text { olive oil tacos }\end{array}$ \\
\hline \multirow{3}{*}{ LUNCH } & $\begin{array}{c}\text { Cauliflower } \\
\text { with } \\
\text { vinaigrette } \\
\text { dressing }\end{array}$ & $\begin{array}{l}\text { Roasted } \\
\text { chicory } \\
\text { heads }\end{array}$ & Pisto & $\begin{array}{l}\text { Stewed } \\
\text { lentils. }\end{array}$ & $\begin{array}{l}\text { Tomato and } \\
\text { basil soup. }\end{array}$ & $\begin{array}{l}\text { Macarons } \\
\text { with } \\
\text { tomato } \\
\text { sauce. }\end{array}$ & $\begin{array}{c}\text { Grilled leeks } \\
\text { with } \\
\text { romesco } \\
\text { sauce. }\end{array}$ \\
\hline & $\begin{array}{l}\text { Stew rabbit } \\
\text { with white } \\
\text { wine and } \\
\text { onions }\end{array}$ & $\begin{array}{l}\text { Grilled } \\
\text { chicken } \\
\text { breast with } \\
\text { potato } \\
\text { sauce. }\end{array}$ & $\begin{array}{l}\text { Stewed beef } \\
\text { with pilaf } \\
\text { rice. }\end{array}$ & $\begin{array}{l}\text { Cod salad } \\
\text { with olives } \\
\text { and } \\
\text { oranges. }\end{array}$ & $\begin{array}{c}\text { Broad beans } \\
\text { with } \\
\text { morcilla. }\end{array}$ & $\begin{array}{c}\text { Pork loin } \\
\text { with } \\
\text { mustard } \\
\text { and carrots. }\end{array}$ & $\begin{array}{c}\text { Grilled } \\
\text { megrim with } \\
\text { roasted } \\
\text { potatoes. }\end{array}$ \\
\hline & Orange & Banana & Mandarins. & $\begin{array}{l}\text { Yoghurt } \\
\text { with kiwi. }\end{array}$ & Custard. & $\begin{array}{l}\text { Candied } \\
\text { oranges. }\end{array}$ & Apple pie. \\
\hline \multirow{3}{*}{ DINNER } & $\begin{array}{c}\text { Endives, } \\
\text { carrots and } \\
\text { feta cheese } \\
\text { salad }\end{array}$ & $\begin{array}{l}\text { Brécol } \\
\text { hervido y } \\
\text { rehogado } \\
\text { con ajos } \\
\text { tiernos }\end{array}$ & $\begin{array}{l}\text { Artichokes } \\
\text { skipped with } \\
\text { Serrano ham }\end{array}$ & $\begin{array}{l}\text { Gazpa- } \\
\text { chuelo }\end{array}$ & $\begin{array}{c}\text { Thistles with } \\
\text { almonds and } \\
\text { pine nuts }\end{array}$ & $\begin{array}{l}\text { Spinaches } \\
\text { with cream } \\
\text { and eggs }\end{array}$ & $\begin{array}{l}\text { Carrot's } \\
\text { cream }\end{array}$ \\
\hline & $\begin{array}{c}\text { Eggplant } \\
\text { omelet with } \\
\text { bread with } \\
\text { tomato }\end{array}$ & Squids & $\begin{array}{c}\text { Gratin } \\
\text { stuffed eggs } \\
\text { with tuna }\end{array}$ & $\begin{array}{c}\text { Cabbage } \\
\text { with minced } \\
\text { chicken and } \\
\text { vegetables }\end{array}$ & $\begin{array}{l}\text { Trout with } \\
\text { tomatoes }\end{array}$ & & $\begin{array}{l}\text { Cheese- } \\
\text { patties with } \\
\text { cabbage } \\
\text { salad }\end{array}$ \\
\hline & $\begin{array}{c}\text { Fruits } \\
\text { yoghurt }\end{array}$ & Pear sauce & Apple & Curd & Mandarins & $\begin{array}{l}\text { Yoghurt } \\
\text { with } \\
\text { walnuts }\end{array}$ & Apple \\
\hline
\end{tabular}


Table A4.5.4. Summer recommended menu of the Mediterranean Diet, with all dishes and ingredients for breakfast, morning-snack, lunch and dinner from Monday to Sunday. Source: own elaboration using the food guidelines elaborated by the Mediterranean Diet Foundation (Fundación Dieta Mediterránea, 2015).

\begin{tabular}{|c|c|c|c|c|c|c|c|}
\hline \multicolumn{8}{|c|}{ SUMMER MENU } \\
\hline & MONDAY & TUESDAY & WEDNESDAY & THURSDAY & FRIDAY & SATURDAY & SUNDAY \\
\hline \multirow[t]{2}{*}{ BREAKFAST } & \multirow[t]{2}{*}{$\begin{array}{l}\text { COFFEE with } \\
\text { milk. } \\
\text { Pancakes } \\
\text { with peaches } \\
\text { and honey. }\end{array}$} & $\begin{array}{l}\text { Orange and } \\
\text { lemon juice. }\end{array}$ & \multirow[t]{2}{*}{$\begin{array}{l}\text { Bread with } \\
\text { goat } \\
\text { cheese, } \\
\text { onion and } \\
\text { olive oil }\end{array}$} & \multirow[t]{2}{*}{$\begin{array}{l}\text { Yoghurt } \\
\text { with } \\
\text { cereals }\end{array}$} & Omelet. & $\begin{array}{l}\text { Homemade } \\
\text { ensaimada. }\end{array}$ & $\begin{array}{c}\text { Bread with } \\
\text { olive oil. }\end{array}$ \\
\hline & & $\begin{array}{c}\text { Yoghurt and } \\
\text { nuts }\end{array}$ & & & Infusion & Orange juice & Infusion \\
\hline $\begin{array}{c}\text { MORNING } \\
\text { SNACK }\end{array}$ & $\begin{array}{l}\text { Bread with } \\
\text { lacón }\end{array}$ & $\begin{array}{c}\text { Manchego } \\
\text { cheese with } \\
\text { oil }\end{array}$ & $\begin{array}{l}\text { Humus } \\
\text { with pita } \\
\text { bread }\end{array}$ & $\begin{array}{c}\text { Vegetables } \\
\text { mix }\end{array}$ & Fruits juice & $\begin{array}{l}\text { Bread with } \\
\text { serrano ham }\end{array}$ & Mussels \\
\hline \multirow{3}{*}{ LUNCH } & $\begin{array}{l}\text { Chick peas, } \\
\text { vegetables } \\
\text { and tuna } \\
\text { salad }\end{array}$ & $\begin{array}{l}\text { Asparagus } \\
\text { with garlic }\end{array}$ & $\begin{array}{c}\text { Grilled } \\
\text { zucchinis }\end{array}$ & $\begin{array}{l}\text { Lentils } \\
\text { cream. }\end{array}$ & $\begin{array}{c}\text { Tomato } \\
\text { salad } \\
\text {. }\end{array}$ & Ajoblanco & Gazpacho \\
\hline & $\begin{array}{l}\text { Cottage } \\
\text { cheese }\end{array}$ & $\begin{array}{c}\text { Pinchos } \\
\text { morunos of } \\
\text { chicken with } \\
\text { pilaf rice }\end{array}$ & $\begin{array}{l}\text { Pasta with } \\
\text { Bolognese } \\
\text { sauce }\end{array}$ & $\begin{array}{l}\text { Sardines } \\
\text { with red } \\
\text { pepper } \\
\text { salad. }\end{array}$ & $\begin{array}{c}\text { Chicken in } \\
\text { pepitoria } \\
\text { sauce with } \\
\text { rice. }\end{array}$ & $\begin{array}{l}\text { Pork fillets } \\
\text { with burgul } \\
\text { wheat salad. }\end{array}$ & $\begin{array}{l}\text { Pork chops } \\
\text { with fried } \\
\text { eggplants }\end{array}$ \\
\hline & Quince & Strawberries & Banana & $\begin{array}{l}\text { Curd with } \\
\text { honey }\end{array}$ & $\begin{array}{l}\text { Peaches } \\
\text { with red } \\
\text { wine }\end{array}$ & Watermelon & $\begin{array}{c}\text { Chocolate } \\
\text { cream }\end{array}$ \\
\hline \multirow{3}{*}{ DINNER } & $\begin{array}{l}\text { Cucumber } \\
\text { cream }\end{array}$ & $\begin{array}{l}\text { Octopus and } \\
\text { vegetables } \\
\text { empanada } \\
\text { with salad. }\end{array}$ & $\begin{array}{l}\text { Green } \\
\text { beans with } \\
\text { garlic. }\end{array}$ & $\begin{array}{l}\text { Pisto with } \\
\text { eggs. }\end{array}$ & $\begin{array}{c}\text { Artichokes } \\
\text { with } \\
\text { serrano } \\
\text { ham. }\end{array}$ & $\begin{array}{c}\text { Tomato and } \\
\text { mozzarella } \\
\text { pizza }\end{array}$ & $\begin{array}{c}\text { Melon with } \\
\text { serrano } \\
\text { ham }\end{array}$ \\
\hline & $\begin{array}{l}\text { Tomato and } \\
\text { mozzarella } \\
\text { sandwich }\end{array}$ & & $\begin{array}{l}\text { Baked sea } \\
\text { bass with } \\
\text { potatoes. }\end{array}$ & & $\begin{array}{l}\text { Hake with } \\
\text { grilled } \\
\text { potatoes }\end{array}$ & Salad & $\begin{array}{l}\text { Vegetables } \\
\text { mix }\end{array}$ \\
\hline & Watermelon & Melon & Cherries & Fruit salad & Melon & $\begin{array}{l}\text { Lemon } \\
\text { sorbet }\end{array}$ & Yoghurt \\
\hline
\end{tabular}


Table A4.5.5. Recommended Menu 1 of the American Diet. All dishes and ingredients for breakfast, morning snack, lunch and dinner from Monday to Sunday. Source: own elaboration following the guidelines of the Center for Nutrition Policy and Promotion (CNPP) of the US Department of Agriculture (USDA, 2015) and the study by Haven et al. (Haven et al., 2015).

\begin{tabular}{|c|c|c|c|c|c|c|c|}
\hline \multicolumn{8}{|c|}{ MENU 1} \\
\hline & MONDAY & TUESDAY & WEDNESDAY & THURSDAY & FRIDAY & SATURDAY & SUNDAY \\
\hline BREAKFAST & $\begin{array}{c}\text { Peanut } \\
\text { Butter. Raisin } \\
\text { Oatmeal. } \\
\text { Orange Juice }\end{array}$ & $\begin{array}{l}\text { Toasted oat- } \\
\text { cereal with } \\
\text { milk and a } \\
\text { banana. } \\
\text { Coffee. Hard- } \\
\text { cooked Egg. }\end{array}$ & $\begin{array}{c}\text { Scrambled } \\
\text { Eggs. Turkey } \\
\text { Sausage Links. } \\
\text { Whole-wheat } \\
\text { Toast with Tub } \\
\text { - Margarine and } \\
\text { Jelly. Apple } \\
\text { Juice. }\end{array}$ & $\begin{array}{c}\text { Banana } \\
\text { Walnut } \\
\text { Oatmeal. } \\
\text { Orange. Low } \\
\text { fat Milk. }\end{array}$ & $\begin{array}{l}\text { Open-faced } \\
\text { Egg and } \\
\text { Tomato on } \\
\text { an English } \\
\text { Muffin. } \\
\text { Apple Juice. }\end{array}$ & $\begin{array}{l}\text { Scrambled } \\
\text { Tofu Burrito } \\
\text { with Salsa } \\
\text { and Black } \\
\text { Beans. Low } \\
\text { fat Milk. }\end{array}$ & $\begin{array}{c}\text { Fantastic } \\
\text { French Toast } \\
\text { with Bread } \\
\text { cake Syrup, } \\
\text { Tub Margarine } \\
\text { and Cinnamon. } \\
\text { Banana. } \\
\text { Orange Juice }\end{array}$ \\
\hline $\begin{array}{c}\text { MORNING } \\
\text { SNACK }\end{array}$ & $\begin{array}{c}\text { Carrot Sticks } \\
\text { with Dip. } \\
\text { Crackers. }\end{array}$ & $\begin{array}{c}\text { Popcorn. } \\
\text { Orange. }\end{array}$ & $\begin{array}{l}\text { Pretzels and } \\
\text { Dip. Banana }\end{array}$ & $\begin{array}{c}\text { Banana } \\
\text { Bread with } \\
\text { Tub } \\
\text { Margarine. } \\
\text { Grapes. }\end{array}$ & $\begin{array}{c}\text { Banana } \\
\text { Bread with } \\
\text { Tub } \\
\text { Margarine. } \\
\text { Low fat Milk. }\end{array}$ & $\begin{array}{l}\text { Yogurt } \\
\text { Parfait. }\end{array}$ & $\begin{array}{c}\text { Banana Bread } \\
\text { with Tub } \\
\text { Margarine. } \\
\text { Low fat Milk. }\end{array}$ \\
\hline \multirow{4}{*}{ LUNCH } & $\begin{array}{l}\text { Tuna- } \\
\text { Cucumber } \\
\text { Wrap with } \\
\text { mayonnaise } \\
\text { and mustard }\end{array}$ & $\begin{array}{c}\text { Green Salad } \\
\text { with Honey } \\
\text { Lemon } \\
\text { Chicken with } \\
\text { Vinaigrette } \\
\text { Dressing }\end{array}$ & $\begin{array}{l}\text { Spaghetti with } \\
\text { tomato sauce }\end{array}$ & $\begin{array}{l}\text { Green Salad } \\
\text { with Tuna } \\
\text { and } \\
\text { Vinaigrette } \\
\text { Dressing. }\end{array}$ & $\begin{array}{c}\text { Peanut } \\
\text { Butter and } \\
\text { Banana } \\
\text { Sandwich. }\end{array}$ & $\begin{array}{l}\text { Crunchy } \\
\text { Chicken } \\
\text { Salad } \\
\text { Sandwich. }\end{array}$ & $\begin{array}{l}\text { Lentil Stew. } \\
\text { Brown Rice }\end{array}$ \\
\hline & Low fat Milk & $\begin{array}{c}\text { Whole-wheat } \\
\text { Bread with } \\
\text { Tub } \\
\text { Margarine }\end{array}$ & $\begin{array}{c}\text { Bread with Tub } \\
\text { Margarine }\end{array}$ & $\begin{array}{c}\text { Whole- } \\
\text { wheat Bread } \\
\text { with Tub } \\
\text { Margarine }\end{array}$ & Celery Sticks & $\begin{array}{l}\text { Carrot } \\
\text { Sticks. }\end{array}$ & $\begin{array}{l}\text { Whole-Wheat } \\
\text { Bread with } \\
\text { Tub Margarine }\end{array}$ \\
\hline & $\begin{array}{c}\text { Low fat } \\
\text { Vanilla Yogurt }\end{array}$ & $\begin{array}{l}\text { Chocolate } \\
\text { Chip Yogurt } \\
\text { Cookie. }\end{array}$ & $\begin{array}{c}\text { Salad with } \\
\text { Vinaigrette } \\
\text { Dressing. }\end{array}$ & $\begin{array}{l}\text { Shake-A- } \\
\text { Pudding }\end{array}$ & & Orange & \\
\hline & & Low fat Milk & Low fat Milk & Low fat Milk & Low fat Milk & Low fat Milk & Low fat Milk \\
\hline \multirow{5}{*}{ DINNER } & $\begin{array}{c}\text { Honey Lemon } \\
\text { Chicken }\end{array}$ & $\begin{array}{l}\text { Spaghetti } \\
\text { with tomato } \\
\text { sauce }\end{array}$ & $\begin{array}{c}\text { Polenta with } \\
\text { Pepper and } \\
\text { Cheese }\end{array}$ & $\begin{array}{c}\text { Marinated } \\
\text { Beef }\end{array}$ & $\begin{array}{c}\text { Mouth- } \\
\text { Watering } \\
\text { Oven-Fried } \\
\text { Fish. }\end{array}$ & Lentil Stew & $\begin{array}{l}\text { Bread-fried } \\
\text { Pork Chop }\end{array}$ \\
\hline & $\begin{array}{c}\text { Brown Rice } \\
\text { Pilaf }\end{array}$ & $\begin{array}{c}\text { Steamed } \\
\text { Broccoli with } \\
\text { Tub } \\
\text { Margarine }\end{array}$ & $\begin{array}{c}\text { Green Beans } \\
\text { with Tub } \\
\text { Margarine }\end{array}$ & $\begin{array}{l}\text { Mashed } \\
\text { Potatoes } \\
\text { with Tub } \\
\text { Margarine }\end{array}$ & $\begin{array}{l}\text { Couscous } \\
\text { with Peas } \\
\text { and Onions }\end{array}$ & Brown Rice & Baked Potato \\
\hline & $\begin{array}{l}\text { Peas and } \\
\text { Corn with } \\
\text { Tub } \\
\text { Margarine }\end{array}$ & $\begin{array}{l}\text { White Roll } \\
\text { with Tub } \\
\text { Margarine. }\end{array}$ & $\begin{array}{l}\text { Chocolate Chip } \\
\text { Yogurt Cookie }\end{array}$ & $\begin{array}{c}\text { Mixed } \\
\text { Vegetables } \\
\text { with Tub } \\
\text { Margarine }\end{array}$ & $\begin{array}{l}\text { White Roll } \\
\text { with Tub } \\
\text { Margarine }\end{array}$ & $\begin{array}{c}\text { Broccoli with } \\
\text { Tub } \\
\text { Margarine }\end{array}$ & $\begin{array}{c}\text { Cabbage Slaw } \\
\text { with } \\
\text { Vinaigrette } \\
\text { Dressing }\end{array}$ \\
\hline & $\begin{array}{c}\text { Chocolate } \\
\text { Chip Cookie } \\
\text { Yogurtt }\end{array}$ & $\begin{array}{l}\text { Shake-A- } \\
\text { Pudding }\end{array}$ & & & Green Beans & $\begin{array}{l}\text { Canned } \\
\text { Pears }\end{array}$ & Apple Juice. \\
\hline & Low fat Milk & Low fat Milk & Low fat Milk & & Coffee & & \\
\hline
\end{tabular}


Table A4.5.6. Recommended Menu 2 of the American Diet. All dishes and ingredients for breakfast, morning snack, lunch and dinner from Monday to Sunday. Source: own elaboration following the guidelines of the Center for Nutrition Policy and Promotion (CNPP) of the US Department of Agriculture (USDA, 2015) and the study by Haven et al. (Haven et al., 2015).

\begin{tabular}{|c|c|c|c|c|c|c|c|}
\hline \multicolumn{8}{|c|}{ MENU 2} \\
\hline & MONDAY & TUESDAY & WEDNESDAY & THURSDAY & FRIDAY & SATURDAY & SUNDAY \\
\hline BREAKFAST & $\begin{array}{c}\text { Raisin } \\
\text { Oatmeal. } \\
\text { Low fat Milk. } \\
\text { Banana with } \\
\text { Peanut } \\
\text { Butter. }\end{array}$ & $\begin{array}{l}\text { Sausage } \\
\text { Omelet. } \\
\text { Hash Brown } \\
\text { Potatoes. } \\
\text { Orange } \\
\text { Juice. }\end{array}$ & $\begin{array}{l}\text { Cold Cereal } \\
\text { with Banana } \\
\text { and Low fat } \\
\text { Milk. Whole- } \\
\text { wheat Toast } \\
\text { with Peanut } \\
\text { Butter. Coffee. }\end{array}$ & $\begin{array}{l}\text { Breakfast } \\
\text { Burrito with } \\
\text { Salsa. Whole- } \\
\text { wheat Toast } \\
\text { with Tub } \\
\text { Margarine and } \\
\text { Jelly. Apple } \\
\text { Juice. }\end{array}$ & $\begin{array}{l}\text { Toasted Oat } \\
\text { Cereal. } \\
\text { Scrambled Egg } \\
\text { with Salsa. } \\
\text { Apple Juice. }\end{array}$ & $\begin{array}{l}\text { Banana } \\
\text { Walnut } \\
\text { Oatmeal. } \\
\text { Hard-boiled } \\
\text { Eggs. } \\
\text { Orange } \\
\text { Juice. }\end{array}$ & $\begin{array}{c}\text { Perfect } \\
\text { Pumpkin Bread } \\
\text { cakes with } \\
\text { Bread cake } \\
\text { Syrup. Turkey } \\
\text { Sausage Link. } \\
\text { Banana. Apple } \\
\text { Juice. }\end{array}$ \\
\hline $\begin{array}{c}\text { MORNING } \\
\text { SNACK }\end{array}$ & $\begin{array}{c}\text { Orange. } \\
\text { Graham } \\
\text { Crackers. } \\
\text { Low fat Milk. }\end{array}$ & $\begin{array}{l}\text { Peanut } \\
\text { Butter on } \\
\text { Banana. Low } \\
\text { fat Milk. }\end{array}$ & $\begin{array}{l}\text { Graham } \\
\text { Crackers. Low } \\
\text { fat Milk. }\end{array}$ & $\begin{array}{c}\text { Apple } \\
\text { Cinnamon Bar. } \\
\text { Low fat Milk. }\end{array}$ & $\begin{array}{c}2 \text { Applesauce } \\
\text { Cookies. Canned } \\
\text { Pineapple } \\
\text { Chunks. }\end{array}$ & $\begin{array}{l}\text { yogurt } \\
\text { Parfait }\end{array}$ & $\begin{array}{l}\text { Popcorn. } \\
\text { Yogurt Pop. }\end{array}$ \\
\hline \multirow{4}{*}{ LUNCH } & $\begin{array}{c}\text { Tuna } \\
\text { Sandwich. }\end{array}$ & $\begin{array}{c}\text { Peanut } \\
\text { Butter and } \\
\text { Jelly } \\
\text { Sandwich.. }\end{array}$ & $\begin{array}{c}\text { Green Salad } \\
\text { with Salmon } \\
\text { with } \\
\text { Vinaigrette } \\
\text { Dressing. }\end{array}$ & $\begin{array}{l}\text { Roast Beef } \\
\text { Sandwich. }\end{array}$ & White Chili. & $\begin{array}{l}\text { Tofu Salad } \\
\text { Sandwich. }\end{array}$ & $\begin{array}{c}\text { Easy Red } \\
\text { Beans and Rice } \\
\text { with Cheddar } \\
\text { Cheese.. }\end{array}$ \\
\hline & $\begin{array}{c}\text { Cucumber } \\
\text { Slices with } \\
\text { Ranch } \\
\text { Dressing. }\end{array}$ & Apple. & $\begin{array}{c}\text { Whole-grain } \\
\text { Crackers. }\end{array}$ & Carrot Sticks. & $\begin{array}{l}\text { Side Salad with } \\
\text { Vinaigrette } \\
\text { Dressing. }\end{array}$ & $\begin{array}{l}\text { Carrot Sticks } \\
\text { with Ranch. }\end{array}$ & $\begin{array}{l}\text { Side Salad with } \\
\text { Vinaigrette } \\
\text { Dressing. }\end{array}$ \\
\hline & & $\begin{array}{l}\text { Carrot Sticks } \\
\text { with Ranch }\end{array}$ & & $\begin{array}{c}\text { Apple with } \\
\text { Peanut Butter }\end{array}$ & $\begin{array}{l}\text { Whole-wheat } \\
\text { Bread with Tub } \\
\text { Margarine. }\end{array}$ & $\begin{array}{c}\text { Apple } \\
\text { Cinnamon } \\
\text { Bar. }\end{array}$ & $\begin{array}{c}\text { Whole-wheat } \\
\text { Bread with Tub } \\
\text { Margarine }\end{array}$ \\
\hline & Low fat Milk & Low fat Milk & Low fat Milk & Tea & Low fat Milk & Low fat Milk & Low fat Milk \\
\hline \multirow{5}{*}{ DINNER } & $\begin{array}{l}\text { Red Hot } \\
\text { Fusilli Pasta } \\
\text { with } \\
\text { Parmesan } \\
\text { Cheese. }\end{array}$ & $\begin{array}{l}\text { Quick Tuna } \\
\text { Casserole. }\end{array}$ & $\begin{array}{c}\text { Honey } \\
\text { Mustard Pork } \\
\text { Chops. }\end{array}$ & White Chili & $\begin{array}{l}\text { Misickquatash } \\
\quad \text { (Indian } \\
\text { Succotash with } \\
\text { Ground Beef). }\end{array}$ & $\begin{array}{l}\text { Easy Red } \\
\text { Beans and } \\
\text { Rice with } \\
\text { Cheddar } \\
\text { Cheese }\end{array}$ & $\begin{array}{c}\text { Manly Muffin } \\
\text { Meat Loaf }\end{array}$ \\
\hline & $\begin{array}{c}\text { Green Peas } \\
\text { with Tub } \\
\text { Margarine. }\end{array}$ & $\begin{array}{l}\text { Green } \\
\text { Beans. }\end{array}$ & $\begin{array}{c}\text { Baked Potato } \\
\text { with Tub } \\
\text { Margarine, }\end{array}$ & $\begin{array}{c}\text { Herbed } \\
\text { Vegetables. }\end{array}$ & $\begin{array}{c}\text { Mashed } \\
\text { Potatoes with } \\
\text { Tub Margarine. }\end{array}$ & $\begin{array}{l}\text { Lemon } \\
\text { Spinach. }\end{array}$ & $\begin{array}{c}\text { Mashed } \\
\text { Potatoes with } \\
\text { Tub } \\
\text { Margarine. }\end{array}$ \\
\hline & $\begin{array}{l}\text { White Roll } \\
\text { with Tub } \\
\text { Margarine. }\end{array}$ & White Roll. & Green Cabbage & $\begin{array}{c}\text { Sweet Potato } \\
\text { with Tub } \\
\text { Margarine. }\end{array}$ & $\begin{array}{c}\text { Whole-wheat } \\
\text { Bread with Tub } \\
\text { Margarine. }\end{array}$ & Orange & $\begin{array}{c}\text { Green Peas } \\
\text { with Tub } \\
\text { Margarine }\end{array}$ \\
\hline & $\begin{array}{c}\text { Apple } \\
\text { Cinnamon } \\
\text { Bar. Coffee }\end{array}$ & $\begin{array}{c}\text { Apple } \\
\text { Cinnamon } \\
\text { Bar }\end{array}$ & White Roll & $\begin{array}{l}\text { Chocolate } \\
\text { Pudding }\end{array}$ & & & \\
\hline & Coffee & Coffee & $\begin{array}{c}\text { Applesauce } \\
\text { Cookies }\end{array}$ & Low fat Milk & Low fat Milk & Low fat Milk & Low fat Milk \\
\hline
\end{tabular}




\section{ANNEX V. LINKS TO SUPLEMENTARY MATERIAL OF THE RESEARCH STUDIES}

In order to obtain more information and data, each of the three research studies have supplementary material. Thus, the links that provide such material are:

A. Supplementary material for the first research study: 'Evaluating the water footprint of the Mediterranean and American diets', consists in:

Supplementary material 1: products, quantities, kilograms, serving and kg per person for all the dishes within Mediterranean-Winter recommended menu.

- Supplementary material 2: products, quantities, kilograms, serving and kg per person for all the dishes within Mediterranean-Summer recommended menu.

- Supplementary material 3: products, quantities, kilograms, serving and kg per person for all the dishes within American (USDr) recommended menu 1.

> Supplementary material 4: products, quantities, kilograms, serving and kg per person for all the dishes within American (USDr) recommended menu 2.

All of them are provided in the following link of the JCR International Journal "Water":

https://www.mdpi.com/2073-4441/8/10/448\#supplementary 
B. The second research study: 'Food consumption and waste in Spanish households: water implications within and beyond national borders', have the following supplementary material:

> Supplementary material 1: data for household's final imported virtual water of food current consumption. Data for the country (and continent) of import, quantity ( $\mathrm{kg}$ ) of import and the assessment of their green, blue and grey imported water for each of the food products within the analysis (84 of 199, the $70 \%$ of the final food house consumption).

Supplementary material 2: kilograms consumed and wasted per capita year in Spanish households for all the 199 products within the analysis.

Supplementary material 3: the Water Footprint assessment of the current food consumption in Spanish households. Data of: the consumption (kg/capita per year), national Spanish water footprint (divided into its Green, Blue and Grey components), national production and imported quantities in tones, the imported virtual water (divided into its Green, Blue and Grey components) and the assessment of their final green, blue, grey and total WF for each of the food products within the analysis (199 in total).

Supplementary material 4: the Water Footprint assessment of the food waste in Spanish households. Data of: the waste (kg/capita per year), national Spanish water footprint (divided into its Green, Blue and Grey components), national production and imported quantities in tones, the imported virtual water (divided into its Green, Blue and Grey components) and the assessment of their final green, blue, grey and total WF for each of the food products within the analysis (199 in total).

> Supplementary material 5: data for household's final imported virtual water of food waste. Data for the country (and continent) of import, quantity $(\mathrm{kg})$ of import and the assessment of their green, blue and grey imported water for each of the food products within the analysis (84 of 199, the $70 \%$ of the final food house consumption).

All of them are provided in the following link of the JCR International Journal "Ecological Indicators":

https://www.sciencedirect.com/science/article/pii/S1470160X18300633\#m000 $\underline{5}$ 


\section{The supplementary material for the third research study: 'Evaluating the water footprint of the Mediterranean and American diets', are:}

Supplementary material 1: the Water Footprint assessment of the current food consumption and the estimated Mediterranean Diet in Spanish households. Data of: the food current and the Mediterranean diet consumption ( $\mathrm{kg} / \mathrm{capita}$ per year), national Spanish water footprint (divided into its Green, Blue and Grey components), national production and imported quantities in tones, the imported virtual water (divided into its Green, Blue and Grey components) and the assessment of their final green, blue, grey and total WF for each of the food products within the analysis (199 in total) for the two diets.

Supplementary material 2: the Nutritional analysis assessment of the current food consumption and the estimated Mediterranean Diet in Spanish households. Data of: the food current and the Mediterranean diet consumption (kg/capita per year). Also data for the eight nutritional values analyzed were: Energy (Kcal), Proteins (g), Fats (g), Carbohydrates (g), Fiber (g), Water (g), Minerals (mg) and Vitamins (mg), per capita day for each of the food products within the analysis (199 in total) for the two diets.

Supplementary material 3: the Nutritional Water Productivity assessment of the current food consumption and the estimated Mediterranean Diet in Spanish households. Data of: the food current and the Mediterranean diet consumption (kg/capita per year), national Spanish water footprint (divided into its Green, Blue and Grey components), national production and imported quantities in tones, the imported virtual water (divided into its Green, Blue and Grey components) and the assessment of their final green, blue, grey and total WF for each of the food products within the analysis (199 in total) for the two diets. Also data for the eight nutritional values analyzed were: Energy (Kcal), Proteins (g), Fats (g), Carbohydrates (g), Fiber (g), Water (g), Minerals (mg) and Vitamins (mg), per capita day for each of the food products within the analysis (199 in total) for the two diets. Finally, data for green, blue and grey NWP of each nutritional component for both diets.

All of them they are provided in the following link:

https://cloud9.cesvima.upm.es/index.php/s/8nrBcNwAuw1h54Z 


